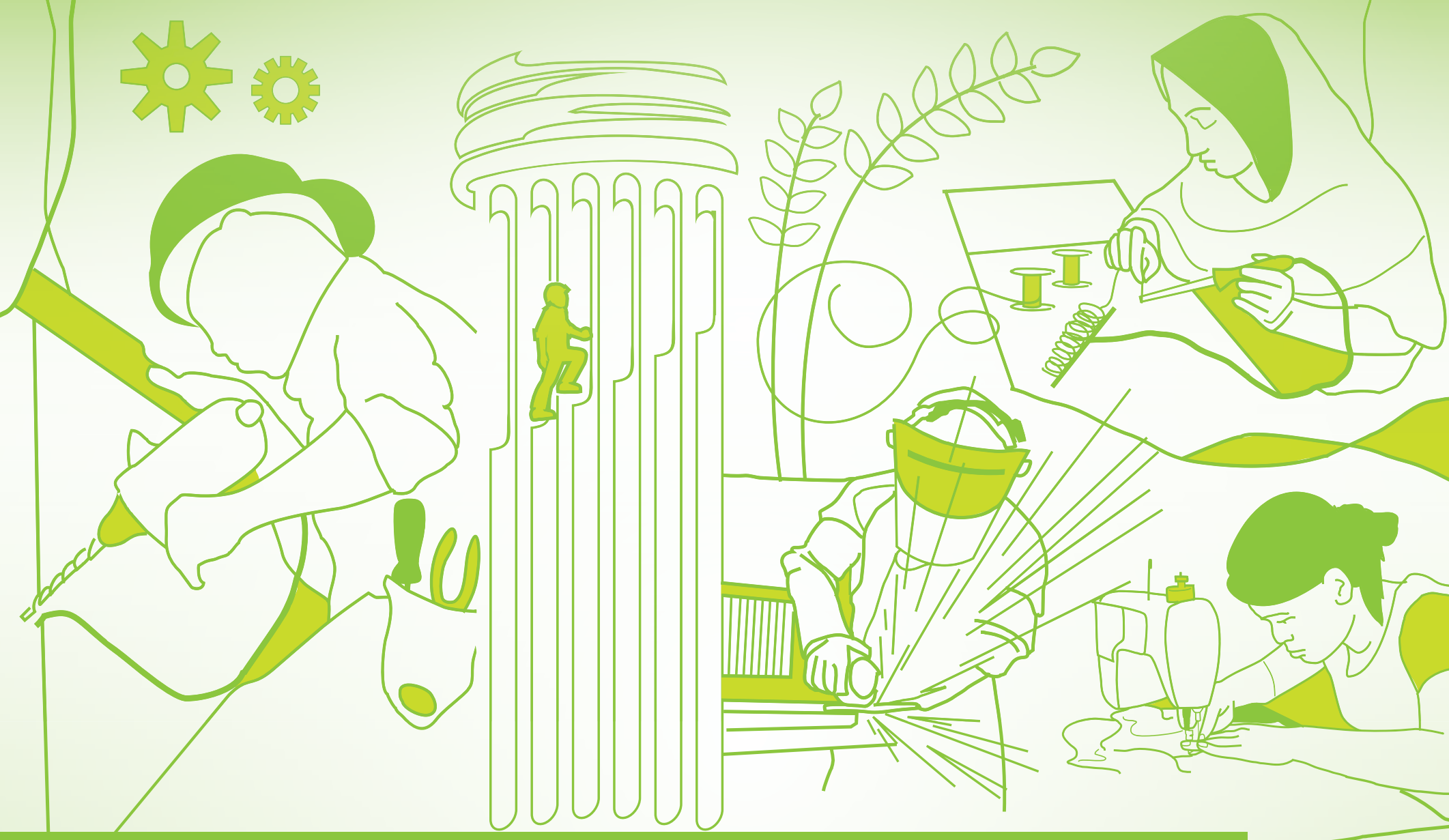


INNOVATIVE STRATEGIES FOR

ACCELERATED HUMAN RESOURCE DEVELOPMENT IN SOUTH ASIA

\section{TEACHER PROFESSIONAL DEVELOPMENT}

Special Focus on Bangladesh, Nepal, and Sri Lanka 
(C) 2017 Asian Development Bank

6 ADB Avenue, Mandaluyong City, 1550 Metro Manila, Philippines

Tel +632632 4444; Fax +6326362444

www.adb.org

Some rights reserved. Published in 2017.

ISBN 978-92-9261-036-4 (print), 978-92-9261-037-1 (electronic)

Publication Stock No. TCS179078

DOI: http://dx.doi.org/10.22617/TCS179078

The views expressed in this publication are those of the authors and do not necessarily reflect the views and policies of the Asian Development Bank (ADB) or its Board of Governors or the governments they represent.

ADB does not guarantee the accuracy of the data included in this publication and accepts no responsibility for any consequence of their use. The mention of specific companies or products of manufacturers does not imply that they are endorsed or recommended by ADB in preference to others of a similar nature that are not mentioned.

By making any designation of or reference to a particular territory or geographic area, or by using the term "country" in this document, $A D B$ does not intend to make any judgments as to the legal or other status of any territory or area.

This work is available under the Creative Commons Attribution 3.0 IGO license (CC BY 3.0 IGO)

https://creativecommons.org/licenses/by/3.0/igo/. By using the content of this publication, you agree to be bound by the terms of this license. For attribution, translations, adaptations, and permissions, please read the provisions and terms of use at https://www.adb.org/terms-use\#openaccess

This CC license does not apply to non-ADB copyright materials in this publication. If the material is attributed to another source, please contact the copyright owner or publisher of that source for permission to reproduce it. $A D B$ cannot be held liable for any claims that arise as a result of your use of the material.

Please contact pubsmarketing@adb.org if you have questions or comments with respect to content, or if you wish to obtain copyright permission for your intended use that does not fall within these terms, or for permission to use the ADB logo.

Notes:

In this publication, “\$” refers to US dollars.

Corrigenda to ADB publications may be found at http://www.adb.org/publications/corrigenda 


\section{CONTENTS}

Tables, Figures, and Box $v$

Foreword vii

Preface viii

Abbreviations $x$

Executive Summary xii

I. Introduction 1

A. Structure and Organization of the Region's General School Education Sector $\quad 1$

B. Governance and Management 3

C. Financing the Education Sector 6

D. Performance of the School Sector 6

II. Teacher Recruitment, Supply, and Employment Conditions 9

A. Demand Forecast 9

B. Teacher Database $\quad 11$

C. Targeting Demand Forecast 12

D. Recruitment and Appointment of Teachers 13

E. Various Categories of Teachers and Job Differentiation 15

F. Teacher Performance Monitoring 16

G. Conditions of Employment Adopted by Countries in the Region 18

III. Teacher Quality Assurance 19

A. Minimum Quality Standards and Quality Monitoring 19

B. Institutional and Organizational Arrangements for Quality Monitoring 23

IV. Teacher Training Provisions

$\begin{array}{ll}\text { A. Teacher Training Institutions } & 25 \\ \text { B. Teach } & 27\end{array}$

$\begin{array}{ll}\text { B. Teacher Training Programs } & 27\end{array}$

C. Delivery of Teacher Training Programs 33 
V. Analysis of the Teacher Education System 35

A. Demand Forecast $\quad 35$

B. Structure of the Education System: Implication for Teacher Demand and Supply $\quad 36$

C. Institutional Reform and Partnerships for Training Providers $\quad 37$

D. Utilization of Existing Teacher Training Facilities 39

E. Teacher Quality Improvement $\quad 40$

VI. Way Forward: Teacher Professional Development Priorities 45

A. Systems Approach to Teacher Quality Improvement 45

B. Institutional Issues $\quad 46$

$\begin{array}{ll}\text { References } & 51\end{array}$

Appendix 1: Teacher Professional Development in Bangladesh 53

A. Education System $\quad 53$

B. Teacher Development, Recruitment, and Supply $\quad 55$

C. Teacher Quality Assurance $\quad 62$

D. Provision of Teacher Education and Training 65

E. Programs and Projects for Teacher Education Reform 70

F. Analysis of the Teacher Education and Training System 73

G. Conclusion and Recommendations $\quad 82$

$\begin{array}{ll}\text { References } & 88\end{array}$

Appendix 2: Teacher Professional Development in Nepal 89

A. Education System in Nepal $\quad 89$

B. Teacher Development, Recruitment, and Supply $\quad 91$

C. Teacher Quality Assurance $\quad 99$

D. Provision of Teacher Education and Training 104

E. Programs and Projects for Teacher Education Reform 113

F. Analysis of the Teacher Education and Training System 116

G. Recommendations 129

References $\quad 132$

Appendix 3: Teacher Professional Development in Sri Lanka 135

A. Overview of the School Education Sector 135

B. Teacher Development, Recruitment, and Supply 139

C. Recruitment and Promotion of Teachers 142

D. Establishment of Quality Assurance Branch 144

E. Programs for Teacher Education Reform 154

F. Analysis of the Teacher Education System 159

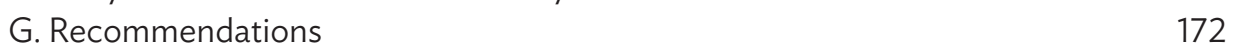

References 176 


\section{TABLES, FIGURES, AND BOX}

Tables

1 Main Categories of Schools and Numbers of Teachers and Students in Each Country 3

2 Net Enrollment Rate in Primary Education by Country 7

3 Teacher Training Infrastructure in Each Country 39

A1.1 Bangladesh-Share of Education in Gross Domestic Product and National Budget, 2011-2013 54

A1.2 Bangladesh-Recurrent Salary and Nonsalary Expenditures by Level, 2010

A1.3 Bangladesh-Gross and Net Enrollment Rates in Primary and Secondary Education, 2010

A1.4 Bangladesh-Number of Institutions, Students, and Teachers in Primary and Secondary Institutions, 2011

A1.5 Bangladesh-Academic Qualifications of Secondary School Teachers 57

A1.6 Bangladesh-Basic Monthly Salary of Government Primary and Secondary School Teachers

A1.7 Bangladesh-Remuneration of Government and Registered Nongovernment Teachers, 2012

A1.8 Bangladesh-Characteristics and Criteria of Different Types of Teacher Training Institutions

A1.9 Bangladesh-Courses of Bachelor of Education Curriculum (1-Year Program) 69

A1.10 Bangladesh-Enrollment in Teacher Education Institutions, $2010 \quad 76$

A1.11 Bangladesh-Number of Teachers in Teacher Education Institutions, $2010 \quad 77$

A1.12 Bangladesh-Strategies for Teacher Professional Development 87

A2.1 Nepal-Distribution of Schools by Level and Enrollment 90

A2.2 Nepal-Education Budget, FY2009-FY2011 91

A2.3 Nepal-Distribution of Budget Allocations, 2013-2014 91

A2.4 Nepal-Distribution of Teachers by School Level and Geographical Region 92

A2.5 Nepal-Teacher Recruitment Authorities by Type of School 94

A2.6 Nepal-Monthly Salary Scale for Government Teachers 96

A2.7 Nepal-Teacher Promotion Pathways 98

A2.8 Nepal-Expected Roles of Different Agencies, Interest Groups,
and Individuals in Quality Monitoring

A2.9 Nepal-Training Providers by Type, Management, and Duration of Training and Target Levels

A2.10 Nepal-Government Professional Development Program (preservice and in-service) 
A2.11 Nepal-Teacher Professional Development Training Phases and Activities

A2.12 Nepal-Training Programs Offered by National Center for Educational Development Other than General Teacher Professional Development Training $\quad 110$

A2.13 Nepal-Brief Specifications of Teacher Education Reforms Initiated in the Post-2008 Period

A3.1 Sri Lanka-Government Schools by Type and Functional Grade 136

A3.2 Sri Lanka-Performance Indicators of the Education Sector 137

A3.3 Sri Lanka-Total Public Expenditure on General Education 138

A3.4 Sri Lanka-Recruitment Methods for Entry-Level Teachers 140

A3.5 Sri Lanka-Approved Cadre of Teachers for Government Schools, 2013

A3.6 Sri Lanka-Teachers by Professional Qualification, 2013

A3.7 Sri Lanka-Teachers by Age Group, $2010 \quad 142$

A3.8 Sri Lanka-Teachers by Functional Grade of School, 2010

A3.9 Sri Lanka-Teacher Education Courses Conducted by Universities 147

A3.10 Sri Lanka-Courses Conducted by the National Institute of Education 149

A3.11 Sri Lanka-Teacher Training Providers 154

A3.12 Sri Lanka-Summary of Needs and Gaps

in Computer-Assisted Teaching and Learning 170

Figures

1 Decentralized Levels of Education Sector Governance for Each Country 4

2 Interdependency of a National Teacher Standards Framework 21

3 Key Functional Elements in a Quality Assurance System 23

4 Typical Structure of Teacher Education Program 28

5 Qualifications Framework Illustrating Gradual Progression to Higher Knowledge and Skills 29

6 Technological Pedagogical Content Knowledge Approach 33

$7 \quad$ Example of e-Library for Secondary Science and Mathematics 43

A1.1 Bangladesh-Career Path of Private School Teachers 59

A1.2 Bangladesh—Proposed Teachers' Professional Development System 84

A1.3 Bangladesh-Teacher Development Policy Diagram 85

A3.1 Sri Lanka-Conceptual Framework for Teacher Professional Development 173

Box

A2.1 Nepal-Roles and Responsibilities of Head Teachers and Teachers 


\section{FOREWORD}

W hile the South Asian countries in this study have, in recent years, given increased attention and substantial investment in strengthening teacher professional development as a crucial and integral strategy to achieve quality and relevance of education, the outcomes have been varied and uneven across countries and teacher development areas. With the aim to enhance the capacity of policy makers in the South Asia region to integrate innovative approaches in policies and strategic plans in the education sector, this work identifies specific priorities that would enable interventions to concentrate on the most efficient and effective strategies for teacher professional development. As part of a series of four reports, this study on teacher professional development complements and cuts across the other crucial themes in education and training today: public-private partnership in education, information and communication technology (ICT), and assessment of student learning outcome.

Overall, ensuring quality, enabling policy environment, sound institutional arrangement, and sustainable financing remain some of the key challenges. This report presents definitive, systematic, and feasible courses of action that include review and further revision of critical policies, fine-tuning institutional and organizational arrangements as well as recruitment and deployment processes, tightening the alignment of teacher education curricula to that of the desired school outcomes and ensuring value addition of in-service training programs, capitalizing on the strength of both teacher training institutes and universities to improve the quality of teachers in pedagogy and subject content, implementing research-based well-designed ICT teaching and learning resources, and optimizing the use of education management and teacher management information systems by cultivating capacity for policy analytics.

South Asia's huge opportunities arising from its demographic dividend could be harnessed fully only if it is able to provide skills to a large number of new entrants to the labor market every year and upskill the expanding labor force that is still undereducated and inadequately trained compared with their counterparts in other regions. South Asia must capitalize on innovations, knowledge, and skills by building a strong base for foundational skills in school education and reinforced by high-quality technical and vocational education and training and higher education. This can only be facilitated and made more effective by optimizing the benefits from effective and efficient mechanisms in the four aforementioned focus areas. South Asian countries are poised to transition from low-skilled labor to higher productivity and globally competitive labor and they are all ready to build up investments in human capital development.

\section{Hun Kim}

Director General

South Asia Department, Asian Development Bank 


\section{PREFACE}

T his report provides analyses of the existing policy environment, current practices, and present reform initiatives in teacher professional development in Bangladesh, Nepal, Sri Lanka, and, to a limited extent, Bhutan and Maldives.

Business as usual will not lead to desired outcomes. It is important to revisit how teachers are recruited; how their professional development is enhanced; and how they remain updated, current, and motivated to continue, encourage, and cultivate learning-not just for bright students, but especially for those who are lagging. The importance of teachers in improving the overall quality of the education system should be considered through fresh perspectives. With the availability of technology and the support and resources provided by the governments and various institutions involved in improving school quality, it is important to develop teachers as facilitators and not as the sole source of knowledge and influence.

This report puts forward key recommendations including formulation or improvement of a national teacher standards framework to outline core teacher competencies and performance indicators. Under such a framework, a national teacher registration and licensing system is deemed imperative in ensuring quality of teacher training institutions and programs through registration and accreditation. A basic framework and principles are also essential in bringing together emerging lessons learned and demonstrated good practices.

It is not equitable to wait for all teachers to be ready in order to improve the learning outcomes of students. Barriers to development of a pool of competent teachers, particularly in science, technology, engineering, and mathematics, can be addressed with innovative solutions and teaching techniques. The full potential of information and communication technology should be harnessed to aid both preservice and in-service teacher training and professional development, as well as manage teacher demand and supply through a reliable education management information system as well as sound recruitment and deployment policies and processes.

The regional synthesis report was prepared by Hitendra Pillay, international consultant, and the country reports were prepared by national experts: Iqbal Aziz Muttaqi for Bangladesh, Yagya Raj Pant for Nepal, and Nihal Herath for Sri Lanka. The country reports have been shared with government officials, particularly from education ministries, and individual experts including practitioners and researchers from academe and pertinent institutions in the respective countries. It benefited from the insights of Abul Basher in Bangladesh; 
Prakash Man Shrestha, Hridaya Bajracharya, and Ganesh Bahadur Singh in Nepal; and Markandu Karunanithy in Sri Lanka. They were also shared with colleagues from the South Asia Human and Social Development Division as well as resident missions in focus countries. The country reports, as well as the consolidated version, were also crossreferenced among the three national consultants in each country to complement the findings from different reports. Brajesh Panth, then lead education specialist from the South Asia Human and Social Development Division, managed and coordinated the studies with support from Rhona Caoli-Rodriguez, the national program coordinator. Excellent administrative assistance was provided by Erwin Salaveria and Rosalia Baeza.

\section{Sungsup Ra}

Director, Human and Social Development Division

South Asia Department, Asian Development Bank 


\section{ABBREVIATIONS}

ASEAN Association of Southeast Asian Nations

BANBEIS Bangladesh Bureau of Educational Information and Statistics

BEd Bachelor of Education

BSc Bachelor of Science

C-in-Ed Certificate in Education

CPD continuing professional development

DEO district education office

Dip-in-Ed Diploma in Education

DSHE Directorate of Secondary and Higher Education

EMIS education management information systems

ETC education training center

HSEB Higher Secondary Education Board

HSTTI higher secondary teacher training institute

ICT information and communication technology

LAN local area network

MEd Master of Education

MOE Ministry of Education

MOPME Ministry of Primary and Mass Education

MQAB Management and Quality Assurance Branch (Sri Lanka)

NCED National Center for Education Development

NCOE National College of Education

NEP National Education Policy (Bangladesh)

NGO nongovernment organization

NIE National Institute of Education (Sri Lanka)

NRs Nepalese rupees 
NTEC National Teacher Education Council (Nepal)

NTRCA Nongovernment Teachers Registration and Certification Authority

NTSF national teacher standards framework

OECD Organisation for Economic Co-operation and Development

PTI primary teacher training institute

RESC regional English support center

SMC school management committee

STR student-teacher ratio

TMIS teacher management information system

TOT training of trainers

TPD teacher professional development

TQI-II Second Teaching Quality Improvement in Secondary Education Project

TSC Teacher Service Commission

TTC teacher training college

ZEO zonal education office 


\section{EXECUTIVE SUMMARY}

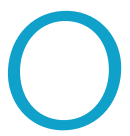

ver the last decade, significant investments have been made by all national governments and development partners to modernize and improve the provision of education services. Strengthening teacher development has been a key component of most of these investments, which thus far has provided mixed results. Continuing to do more of the same may not be an option. This report adopts a 360-degree perspective to review the current status of teacher development, demand and supply, and performance management in five countries from the South Asia region. The report probes beyond just teacher in-service training and teacher job conditions, and investigates systemic and structural issues. The main countries involved are Bangladesh, Nepal, and Sri Lanka, with limited reference to Bhutan and Maldives.

The adopted methodology was a two-stage desk study. A framework derived from international literature that captured a comprehensive view of the key issues related to teacher development was prepared and shared with national researchers to help structure the national reports. Each country, except Bhutan and Maldives, had a researcher who prepared the national reports, with support from an international expert and the Asian Development Bank (ADB). The country reports provided the basic information that informed the regional synthesis. The regional synthesis analyzed significant and common practices being implemented in the region and considered lessons that may help improve the teacher development factors identified within the 360-degree approach.

Given that all countries have finite resources for education, any increase in one area will have a corresponding decrease in another, unless the overall basket of resources for the education sector is increased. Hence, there is a need to adopt a systems approach strategically and gradually help develop high-quality teachers and help ensure optimal performance. The key findings of this desk study are perhaps best presented in the regional synthesis. These are summarized below as key priority issues that will help improve the quality of teachers and the teacher development system's capacity to effectively address systemic issues related to teacher quality, demand and supply, and teacher performance for a 21st century education system.

\section{Key Priority Issues}

(i) Most countries in this region have initiated some form of national teacher standards framework (NTSF), but they all need further strengthening to make the NTSF a centerpiece of teacher quality improvement. Mechanisms must be developed to align all aspects of teacher development to this central framework. 
This may require (i) further revision of policies and legislation; (ii) clearly defining institutional and organizational functions and their interrelatedness within a quality improvement system; and (iii) assigning qualified and dedicated human resources to ensure that the NTSF is developed with international benchmarking, effectively implemented, and regularly upgraded, and that it includes subject content knowledge as well.

(ii) To ensure the NTSF is the centerpiece of teacher quality improvement, national teacher registration should validate compliance with the NTSF and be systematically applied to all teachers in the country. Periodic license renewal to ensure currency of knowledge and skills should be aligned with the continuing professional development (CPD) programs, which in turn should be aligned with the NTSF. Teacher performance monitoring should also evaluate performance against the expectations inherent in the NTSF. Continuous alignment with the NTSF reinforces the framework's centrality and importance.

(iii) Furthermore, the content of the teacher training programs (preservice, inservice, and CPD) should reflect the expected competencies described in the NTSF for the program to be accredited. The program structure and how various teacher training programs articulate vertically to higher-level programs and across institutions must be clearly explained to explicitly show the value they provide. Also, programs should ensure primary teachers are generalists and that secondary teachers have at least two teaching specializations to provide flexibility in appointments and transfers and avoid contributing to the mismatch. These specifications and differentiations are necessary to increase transparency, make credit transfers explicit, and avoid costly duplications.

(iv) To increase efficiency in teacher development, some of the current practices need urgent review. The process of recruiting candidates and then sending them for training on full salary has to stop-this is not sustainable. Since most countries in the region do not face an acute shortage of trained teachers now, this practice, plus investing heavily in other forms of repeated in-service training, may no longer be necessary or effective. The adoption of the NTSF should help strengthen preservice training, which should reduce the demand for in-service training and help better target the demand for CPD.

(v) There is an oversupply of graduates in all the participating countries looking for jobs. Since many of these graduates end up in the teaching workforce, providing a formal pathway may help manage quality and avoid mismatch. Options such as improving the status of the teaching profession by increasing entry requirements as well as providing NTSF-accredited postgraduate programs to offer pedagogical training to complement their already acquired subject-matter expertise will make teaching more attractive to graduates and will be cheaper for the government.

(vi) Continued investment in infrastructure may not be the best option to improve the quality and supply of teachers as there are many private and public teacher training providers who collectively may have the necessary capacity. The challenge is how to leverage this resource to meet the demand. Apart from facilities for preservice training, there are other infrastructure facilities, such as the resource centers and education training centers in rural areas, which are grossly underutilized and poorly maintained due to lack of government recurrent budget for ongoing operation. There is an urgent need to inventory all available facilities before considering further infrastructure investments for teacher development. 
(vii) To improve the quality of teachers, leveraging the strength of teacher training institutes for pedagogy and the universities for subject content should be considered. The current high volume of CPD training for subject content suggests the current providers are not able to develop all aspects of knowledge and skills pertinent to the profession-hence the need for collaboration between teacher training institutes and universities. These arrangements should not be seen as a "takeover," but as a partnership or twinning arrangement where both institutions are necessary. The training programs should be fully compliant with the NTSF.

(viii) While there has been a lot of emphasis on contemporary pedagogies, such as learner-centered and active learning, many of these are not being practiced (or modeled) in the teacher training programs. Other 21st century learning skills, such as self-directed, self-regulated, and lifelong and adult learning, also are not applied to the design and delivery of teacher training programs. The integration of these new learning approaches should be part of the transformation and modernization of the teacher development system.

(ix) Despite increasing global recognition of information and communication technology (ICT) as a teaching and learning tool, this has not been fully embraced by countries in the region for various reasons. While connectivity has hindered development of any systematic nationwide applications, there are other design options that should be urgently considered to avoid accelerating the digital divide. Including ICT competency in the NTSF, converting some existing rural teacher training centers into ICT hubs, and supporting government-led development of standardized e-learning resources such as open education resources for teacher training and for students should all be given serious consideration as processes for modernizing the teacher development system. There is need to move away from advocacy and engage in more serious research and design to implement ICT as a significant teaching and learning resource.

(x) Most countries in the region have established some form of education management or teacher management information system. These were designed and established when data on the teaching workforce were very limited and largely to track overall demand and supply. Teacher demand has since become more complex, and there are more subcategories (such as data on potential supply chain and subject specialization) that are critical for effective planning. Apart from the ability to collect additional types of data, perhaps the capacity most lacking is the ability to undertake complex analytics. While most countries can produce routine annual teacher statistics, the capacity to produce more finegrained policy analytics is currently lacking.

(xi) Finally, while there are policies related to teacher recruitment, transfer, promotion, and so on, often these are not applied or enforced. This makes it difficult to manage teacher demand and supply. There is a need for the government to demonstrate much stronger political will to implement the policies. While there may be some exceptions in the overall system, these must be treated case by case and through prior government agreement.

These key priorities are detailed in the national and regional reports. It is hoped that this desk study can contribute to the progress of teacher development reform to prepare 21st century teachers to enhance education in the region. 


\section{INTRODUCTION}

T he countries included in this study are Bangladesh, Nepal, Sri Lanka, and, to a lesser extent, Bhutan and Maldives. These countries have a lot in common, details of which can be found in the appendixes of this report. Geographically, they are situated in South Asia and can be subjected to severe weather conditions such as flooding and monsoon storms, which often disrupt the provision of education. Access to rural and remote areas can be a challenge, which is confounded by challenging mountain terrain, ever-changing riverbeds and floodplains, and civil and political conflicts. Furthermore, they all have a population mix of diverse ethnicities, cultures, religions, and languages.

The economic base of these countries varies significantly and so does their economic success. Sri Lanka, which is now classified as a middle-income country, had a gross domestic product (GDP) growth of 8.2\% in 2011 (Central Bank of Sri Lanka 2012). The government's investment in expanding its industry and service sectors seems to be having an impact, albeit very slowly. To support the government's economic development plan, the education sector should be responsive in providing a well-educated workforce. The case in Nepal is different. ${ }^{1}$ As a consequence of the protracted political transition, the national economy slowed considerably-GDP for 2011 was $3.4 \%$, and has only recently shown signs of recovery. The 2011 GDP for Bangladesh was $6.5 \%$, for Bhutan $8.6 \%$, and for Maldives 6.5\% (ADB 2014, Table 2.9). For fiscal year (FY) 2012, the Nepalese Ministry of Finance budget was approximately $\$ 4.8$ billion, of which $25 \%$ was funded through foreign aid (Nepal MOF 2012b). Because funding provided to the education sector to develop human resource capacity is heavily dependent on foreign aid, more efficient alternative approaches to providing school education services are warranted.

\section{A. Structure and Organization of the Region's General School Education Sector}

In the region, school education is generally structured around primary (grades $1-5$ ), upper primary and lower secondary (grades 6-8), secondary (grades 9-10), and higher secondary and colleges (grades 11-12). ${ }^{2}$ School education comes under the Ministry of Education (MOE) in all of the countries except Bangladesh. In Bangladesh, primary and

\footnotetext{
According to the Nepal Labor Force Survey, 2011, around 22\% of the economically active population is unemployed, and around $73 \%$ of households are engaged in least productive agriculture sectors. Foreign migration for employment is high: around 2 million Nepalese are currently absent from the country and around $56 \%$ families in Nepal have received remittance income in 1 year (Nepal CBS 2011).

2 In Bangladesh, higher secondary education institutions are called colleges.
} 
secondary school education fall under different ministries, which complicates operational management and resource sharing. The management of schools is largely separated between primary and secondary (as is done in most countries of the Organisation for Economic Co-operation and Development [OECD]), but some schools incorporate grades 1-10 or grades 1-12. In Sri Lanka, school types $1 C$ and $1 A B$ are very large schools and have multiple streams of each class covering grades 1-12. These are similar to the model international schools in Bangladesh, which also have very large student populations and cater to grades 1-12.

Furthermore, the confusion between traditional primary (grades 1-8), which is also referred to as "basic education" and the contemporary primary (grades 1-6 in Sri Lanka and Bhutan, grades 1-5 in Bangladesh and Nepal, and grades 1-7 in Maldives) has implications for teacher development and supply. Primary teachers are generalists, whereas, in the region, upper primary and lower secondary teachers are subject specialists. Bangladesh's National Education Policy 2010 suggests restructuring the school system to traditional primary or basic education (grades 1-8) and secondary (grades 9-12). Nepal is considering a similar restructuring. This is a challenging task, and it will be interesting to watch how this develops. A snapshot of the number of schools, teachers, and students in each country is presented in Table 1.

As illustrated in Table 1, except for Bhutan and Maldives, the countries have very large school systems compared to most developed countries. In addition to large student populations, the population density increases the challenge-hence, Bangladesh and Sri Lanka have schools with more than 4,000 students, and some schools must run double shifts. ${ }^{3}$

Due to the uneven distribution of the population, there are also small schools with fewer than 100 children. In Sri Lanka, up to 32\% of schools are of this type. ${ }^{4}$ Bhutan and Maldives have different challenges. Schools and teachers in Maldives are spread across a number of islands situated in vast areas of the Indian Ocean, and in Bhutan they are located in rough and almost inaccessible mountains. This has implications for teacher development, supply, and monitoring. Alternatives such as boarding schools with better facilities can successfully enhance participation in these remote areas, as can be seen in the hill and mountain regions of Bhutan and Nepal. The notion of equity needs to be reassessed-equity does not mean everyone has the same form of education; instead, everyone has access to some form of quality education. Some communities are willing to send their children to boarding school or encourage them to travel a few kilometers to get to school, whereas others expect local schools to be built at their doorsteps. This requires some strategic thinking-if all financial resources are directed to building more schools, there will be less for other resources such as teacher training and provision of teaching and learning materials. Prudent use of information and communication technology (ICT) can help address diverse needs more efficiently as technology develops further.

\footnotetext{
3 Due to the overcrowding caused by internal migration, many schools are forced to run two shifts in a day to ensure all children have access. This is not the best solution but is necessary. Teachers are asked to teach both shifts.

4 This is particularly common in Sri Lanka and the mountain region in Nepal.
} 
Table 1: Main Categories of Schools and Numbers of Teachers and Students in Each Country

\begin{tabular}{|c|c|c|c|c|c|c|c|c|}
\hline $\begin{array}{l}\text { Country/ } \\
\text { Year }\end{array}$ & \multicolumn{2}{|c|}{ Sri Lanka (2012) } & \multicolumn{2}{|c|}{ Nepal (2012) } & \multicolumn{2}{|c|}{ Bangladesh (2011) ${ }^{a}$} & \multirow{2}{*}{\begin{tabular}{l}
\multicolumn{1}{c}{$\begin{array}{l}\text { Bhutan } \\
(2013)\end{array}$} \\
\multicolumn{1}{c}{ Primary } \\
(grades 1-6) \\
$S-347$ \\
T- 2,495 \\
ER $-47,437$
\end{tabular}} & \multirow{2}{*}{$\begin{array}{l}\begin{array}{c}\text { Maldives } \\
(2013)\end{array} \\
\begin{array}{l}\text { Primary } \\
\text { (grades 1-7) }\end{array} \\
\text { S- } 208 \\
\text { T - 3,411 } \\
\text { ER - 39,408 }\end{array}$} \\
\hline \multirow[t]{4}{*}{$\begin{array}{l}\text { Level or } \\
\text { Sublevel }\end{array}$} & $\begin{array}{l}\text { Primary } \\
\text { (grades 1-5) }\end{array}$ & $\begin{array}{l}S-2,945 \\
T-22,185 \\
E R-376,117\end{array}$ & $\begin{array}{l}\text { Primary } \\
\text { (grades 1-5) }\end{array}$ & $\begin{array}{l}S-33,881 \\
T-173,714 \\
E R- \\
4,782,885\end{array}$ & $\begin{array}{l}\text { Primary } \\
\text { (grades 1-8) }\end{array}$ & $\begin{array}{l}S-78,685 \\
T-395,381 \\
E R- \\
16,957,894\end{array}$ & & \\
\hline & $\begin{array}{l}\text { Secondary } \\
\text { (grades } \\
1-10 \text { ) }\end{array}$ & $\begin{array}{l}S-4,045 \\
T-67,071 \\
E R- \\
904,120\end{array}$ & $\begin{array}{l}\text { Lower } \\
\text { secondary } \\
\text { (grades 6-8) }\end{array}$ & $\begin{array}{l}S-13,791 \\
T-48,848 \\
E R- \\
1,812,680\end{array}$ & $\begin{array}{l}\text { Secondary } \\
\text { (grades } \\
9-12 \text { ) }\end{array}$ & $\begin{array}{l}S-19,070 \\
T-223,555 \\
E R- \\
7,510,218\end{array}$ & $\begin{array}{l}\text { Lower } \\
\text { secondary } \\
\text { (grades } 7-8 \text { ) } \\
S-92 \\
\text { T }-2,114 \\
\text { ER }-47,244\end{array}$ & $\begin{array}{l}\text { Lower } \\
\text { secondary } \\
\text { (grades } \\
8-10 \text { ) } \\
\text { S- } 192 \\
\text { T - 3,081 } \\
\text { ER - } 19,876\end{array}$ \\
\hline & $\begin{array}{l}\text { 1C Higher } \\
\text { secondary } \\
\text { (grades } \\
1-12 \text { ) }\end{array}$ & $\begin{array}{l}S-2,027 \\
T-73,383 \\
E R- \\
1,297,300\end{array}$ & $\begin{array}{l}\text { Secondary } \\
\text { (grades } \\
9-10)\end{array}$ & $\begin{array}{l}S-7938 \\
T-35,675 \\
E R- \\
848,569\end{array}$ & & & $\begin{array}{l}\text { Middle } \\
\text { secondary } \\
\text { (grades } \\
9-10 \text { ) } \\
\text { S- } 61 \\
\text { T-2,005 } \\
\text { ER - 41,116 }\end{array}$ & $\begin{array}{l}\text { Higher } \\
\text { secondary } \\
\text { (grades } \\
11-12 \text { ) } \\
S-37 \\
\text { T - 567 } \\
\text { ER - 4,138 }\end{array}$ \\
\hline & $\begin{array}{l}\text { 1AB Higher } \\
\text { secondary } \\
\text { (grades } \\
1-12 \text { ) }\end{array}$ & $\begin{array}{l}S-716 \\
T-60,247 \\
E R- \\
1,396,304\end{array}$ & $\begin{array}{l}\text { Higher } \\
\text { secondary } \\
\text { (grades } \\
11-12 \text { ) }\end{array}$ & $\begin{array}{l}S-3382 \\
T-17,445 \\
E R-353,338\end{array}$ & & & $\begin{array}{l}\text { Higher } \\
\text { secondary } \\
\text { (grades } \\
11-12 \text { ) } \\
\text { S- } 53 \\
\text { T-1,779 } \\
\text { ER-33,520 }\end{array}$ & \\
\hline
\end{tabular}

$\mathrm{ER}=$ student enrollment $\mathrm{S}=$ number of schools, $\mathrm{T}=$ number of teachers.

a Bangladesh data are aggregated as primary and secondary to match the government's new National Education Policy, which recommends reforming the education structure to two levels.

Sources: Sri Lanka data: Ministry of Education. http://www.moe.gov.lk/english/. Colombo; Nepal data: Department of Education. Community School Capacity Development Program. Kathmandu; Department of Education. 2012. Status Report-2011: School Sector Reform Program; Second Higher Education Project; Community School Capacity Development Program; Education for All Shishu Vikas Karyakram. Sanothimi; Department of Education. School Level Educational Statistics of Nepal: Consolidated Report 2011. Kathmandu; Department of Education. School Sector Reform Program, Second Higher Education Project. Kathmandu; and Department of Education. Status Report-2011. Kathmandu; Bangladesh data: Bangladesh Bureau of Educational Information and Statistics, 2011; Bhutan data: Ministry of Education, Policy and Planning Division. 2013. Annual Education Statistics 2013. Draft; Maldives data: Ministry of Education, School Statistics 2013.

In the region, government policy dictates the use of the national language as the medium of instruction, despite every country having several different languages and dialects. Sri Lanka, coming out of very long internal conflict, is slightly different in that it has adopted three mediums of instruction as the national policy: Sinhala, Tamil, and English. This means three different sets of schools, each for a different medium of instruction, which again has implications for teacher development and supply.

\section{B. Governance and Management}

While most of the schools noted in Table 1 are government schools, there are other types of schools and management models. For example, institutional schools in Nepal are managed by school management committees; the former Bangladesh Rehabilitation Assistance 
Committee (BRAC) schools in Bangladesh are managed by a nongovernment organization (NGO) trust; madrasahs in some of the countries are managed by Islamic foundations; and private schools in Sri Lanka ${ }^{5}$ are managed by school boards. This diversity is supported in all of the countries in the region, and most of these private schools follow the national school curriculum. In Sri Lanka, some private schools follow the "advanced level" and "ordinary level" curricula from the British education system. Similarly, in Nepal, there are twinning arrangements between local and international secondary schools that often, in addition to the national curriculum, provide pathways to international universities and overseas work opportunities. These private schools do not fall under the management of the MOE, and therefore present diversity in management and curriculum implementation, confounded by challenges of quality and equity.

All countries in the region have adopted some form of decentralized governance model to effectively provide services to remote and rural communities. Given the geography of these countries, it is impossible to manage from the center. However, despite accepting decentralized management, there is still a high level of central control exerted in all the countries. Hopefully, as the system matures, more authority, responsibility, and accountability will be delegated to the decentralized posts. Figure 1 illustrates the levels of decentralized posts in each country. With each intermediary level comes increased transaction costs and another layer of bureaucracy.

\section{Figure 1: Decentralized Levels of Education Sector Governance for Each Country}

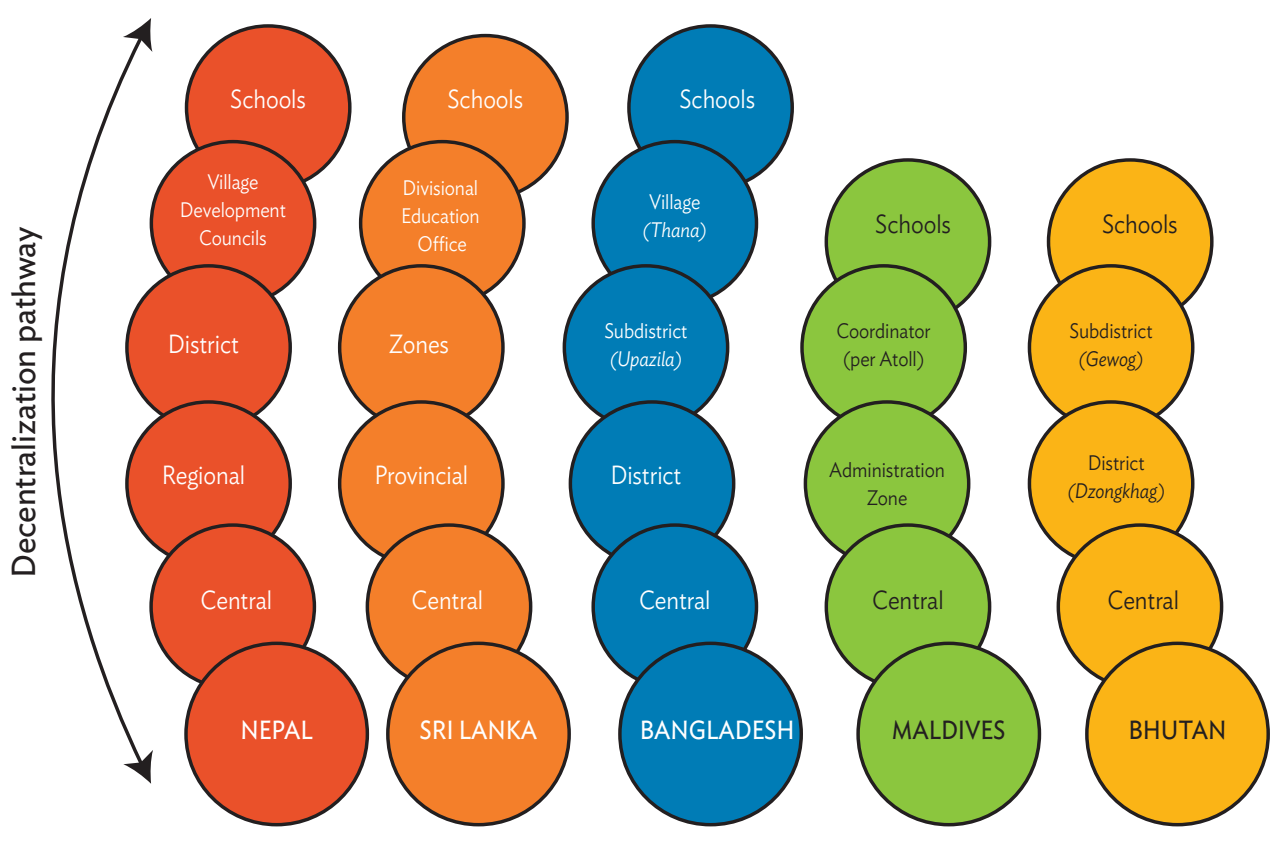

Source: Author's illustration.

5 In 2012, there were 98 private schools with 121,764 students and 5,804 teachers. 
One of the ongoing challenges with governance in all these countries is the human resource capacity and the clarity of roles of personnel at the central education ministry. For instance, in most of these countries, teacher training is still managed and delivered by the central ministry through a training of trainers (TOT) process, using district-level training sites. People travel from the center or province and district to conduct training at the district level. This is neither efficient nor effective and does not help build local capacity to provide ongoing training-related support. The role of the centralized training division should be to develop training policies, review training demand, allocate funds, and monitor the outcomes. The actual training should be done by local institutions; unfortunately, this practice has not yet been fully developed. Maximizing the function of decentralized outposts and using local institutions and expertise to implement innovations has room for further development.

For instance, donor-supported teacher training in Bangladesh (in both secondary and primary education) has always been implemented by the Training Division in the central ministry using TOTs recruited from various places. TOTs receive training in Dhaka and then travel to different districts to train the teachers. There is limited involvement of the local universities, primary teacher training institutes and colleges, the Higher Secondary Teachers' Training Institute, and the Bangladesh Madrasah Teachers' Training Institute. Leveraging the resources of existing institutions through mutually beneficial partnership arrangements needs to be encouraged because such an approach will not only be efficient but also simultaneously develop local capacity.

Decentralization is not just about building facilities for the MOE to host local administration and training events, it also means using local universities and other educational institutions to plan and deliver training to suit local demand. The center should develop clear and precise briefs for the training programs and invite local providers to submit proposals. Using cost- and quality-based evaluation, local providers should be selected to deliver the training. This approach not only empowers the local stakeholders but also encourages competition and innovation. It encourages a shift from the current supply-side, guaranteed annual training quota system to a demand-driven system based on cost and quality. The center's role is to finance and monitor the success of such initiatives and identify lessons that may help improve subsequent training programs. If the expected outcomes are not being achieved, then the program designer and the service delivery provider need to be advised accordingly. The MOE should take measures to avoid repeating the mistakes. As a general rule, in a decentralized system, the central organization develops policies and national sector budgets, supports human resource development and supply, analyzes outputs, and evaluates teachers' performance at the national level. The decentralized organizational units implement the policies locally and supply necessary information to the center for planning and budgeting.

One significant factor that seems to inhibit the education system's ability to improve its performance is the high turnover of senior MOE staff. This is partly caused by the practice of deputizing staff to senior-level vacancies, which is often for only a short time before they are reassigned to another position. This legacy of the British colonial system-an administrative cadre that is rotated to fit any sector-is detrimental to initiatives to strengthen the capacity of education senior staff. Contemporary wisdom from OECD countries supports this view. The provision of education is becoming more complex and 
thus requires specific sector knowledge and capacity to analyze the current situation for planning, monitoring, and financing. Developing the necessary competencies to provide strong leadership for continuous improvement requires time and dedication to learn the conceptual and functional aspects of the system - and the high turnover of senior staff-does not help to achieve this. Professional postgraduate programs in education management and governance, education finance, and education policy and planning should be considered to ensure supply of appropriately qualified education leadership.

\section{Financing the Education Sector}

Despite the financial challenges, these countries value education and recognize that it is central to enhancing their national economic growth and for their social and political cohesion. In Nepal, the government spent $17 \%$ of its national budget on school education in FY2012 (Nepal MOF 2012a). However, it must be noted that around 25\% of the Nepalese government budget is supported through foreign aid. In 2010, Bangladesh spent about $2.3 \%$ of GDP in education, the lowest among the neighboring countries. This was about 9.0\% of the total government annual budget. In FY2013, its national budget allocation for education increased to $11.5 \%$ in the revenue and development budget. In Sri Lanka, in 2010, the government spent $7.3 \%$ of the total government national budget on education, which was $1.9 \%$ of its GDP (Central Bank of Sri Lanka 2012). In Bhutan, government expenditure in education in 2013 was 13.9\%, lower than $14.0 \%$ in 2002. Similarly, Maldives' government expenditure in education declined from 19.9\% in 2000 to 16.2\% in 2013 (ADB 2014). We know from experience that the largest portion of the education budget goes to salaries, particularly teachers' salaries.

While sufficient funding is important when building the fundamentals of a system, at some point an optimum threshold is reached, after which other factors may have greater impact than just increasing funding. The Sri Lankan achievement presents an example of this. Even though its government funding for school education, as a percentage of GDP, is low compared with those of other countries in the region, Sri Lanka has managed to transform and become a middle-income country. Improving the education system requires more than money, and the Government of Sri Lanka had the political will to embrace reform.

In Nepal, the government has introduced a policy of free secondary education, which can significantly increase public sector expenditure in education. ${ }^{6}$ Free education without adequate allocation for nonsalary recurrent expenditure will only erode quality. Therefore, the rationale for announcing free education is unclear and may be seen as political expediency rather than a good education sector policy initiative.

\section{Performance of the School Sector}

Performance of the education sector is often judged on two dimensions: (i) its ability to provide access to schooling for all its citizens, and (ii) the quality of the education it provides to prepare its citizens for higher learning or the world of work.

6 As stipulated in the Interim Constitution of Nepal, 2007 (a translation by the United Nations Development Programme was published in January 2009). 
It is acknowledged that access to basic education has improved significantly over the last decade in all the participating countries. There is also significant improvement in the participation of disadvantaged groups such as girls in primary education. However, the flow-on effect from the improved net enrollment rate in primary education is now impacting secondary education, which requires more work in terms of increasing both general enrollment and the participation of women and disadvantaged groups in secondary education. The net enrollment rate in primary education is shown in Table 2. Except for Maldives and Sri Lanka, enrollment has increased in the other countries over the last decade. As enrollment increases across primary and secondary education, the demand for teachers also increases.

Table 2: Net Enrollment Rate in Primary Education by Country (\%)

\begin{tabular}{|l|c|c|c|c|}
\hline \multirow{2}{*}{ Country } & \multicolumn{2}{|c|}{ Before 1990 } & \multicolumn{2}{c|}{ Before 2012 } \\
\cline { 2 - 5 } & NER & Year & NER & Year \\
\hline Bangladesh & 72.0 & 1990 & 96.2 & 2010 \\
\hline Bhutan & 55.0 & 1998 & 91.8 & 2012 \\
\hline India & 78.2 & 1990 & 98.9 & 2011 \\
\hline Maldives & 96.2 & 1997 & 94.9 & 2009 \\
\hline Nepal & 69.3 & 1999 & 98.7 & 2013 \\
\hline Sri Lanka & 99.8 & 2001 & 93.9 & 2012 \\
\hline
\end{tabular}

$\mathrm{NER}=$ net enrollment rate.

Note: Data for secondary education were not readily available for any of the participating countries.

Source: Table 21 in ADB. 2014. Poverty in Asia: A Deeper Look. In Key Indicators for Asia and the Pacific 2014. Manila.

Quality in all these countries is internally judged-none of them have participated in international tests such as the Programme for International Student Assessment or Trends in International Mathematics and Science Study. While progress has been made regarding general literacy and numeracy, there are still issues of concern. For example, in Nepal, the overall pass rate in the School Leaving Certificate has fluctuated between 30\% and 60\% over the last 5 years (Nepal DOE 2012a). These data are contested since there are huge variations between public and private schools, with the latter outperforming their public counterparts by a wide margin. A large percentage of children do not successfully complete secondary education, which forces them to look for low-paying jobs. In Sri Lanka, there has been improvement over the years. Literacy increased from 87.2\% in 1994 to $96.4 \%$ in 2011. In addition, the percentage of students passing the public examinations also increased. The percentage of students passing General Certificate of Education Ordinary Level examinations increased from $22.5 \%$ in 1994 to $60.8 \%$ in 2011, and from $44.4 \%$ to $61.7 \%$ for the Advanced Level. Although the literacy rate in Bangladesh has increased over the past few years, it is still very low when compared internationally. 



\section{TEACHER RECRUITMENT, SUPPLY, AND EMPLOYMENT CONDITIONS}

T eacher demand, in theory, should be linked to projected increase in student enrollment; ${ }^{7}$ diversification of school curriculum (and resultant demand for teachers for new subjects ${ }^{8}$ ); and teacher attrition due to retirement, career change, death, relocation, and so on. If these variables are stable, then demand will be very low. However, some countries in the region have projected attrition rates of up to $20 \%$ in the next 5 years. If these vacancies are filled with well-qualified teachers, then in 5-10 years, a significant core of qualified and experienced teacher will be in the system. This core group can create enough impact to change the total mix of teachers in the workforce. Strategic management of attrition and recruitment of replacements can be excellent additional mechanisms for improving the quality of the teaching workforce.

\section{A. Demand Forecast}

Annual school censuses are used routinely to collect school-level data, including teacher demand, and have been practiced for a long time. However, the accuracy of such data and the timeliness of reporting vary significantly within each country and between the countries in the region. It is acknowledged that the rural and remote geography and lack of sufficient training of the head teachers and the district education officers contribute to the late or incomplete submissions of the census data. In Nepal, teacher allocations are based on student numbers, which has led to schools inflating student numbers to seek additional teachers. In Bangladesh, the number of monthly payment orders given to secondary schools is also based on student numbers and similar concerns have been raised. All stakeholders agree that access to a robust database is critical for effective and efficient planning of teacher demand and supply. The census reporting process should be simplified and roles and responsibilities of stakeholders made explicit so that they are accountable for the quality of the data and timely reporting. In Bangladesh, the job differentiation between the education management information system (EMIS) cells in primary and secondary education divisions and the Bangladesh Bureau of Educational Information and Statistics is a source of constant tension and illustrates conflicting and/or duplicated roles.

\footnotetext{
This may be influenced by the current student enrollment and the projected increase due to increased enrollment rates plus student age cohort in the population.

8 In Sri Lanka, the government recently introduced technology subjects in secondary schools. This requires additional teachers with new knowledge and skill sets.
} 
While the Ministry of Education (MOE) in most countries manages the census reporting, the process of determining teacher demand varies. For example, in Nepal there is an overlap between the Department of Education and the Teacher Service Commission, where both are involved in demand forecasting. As a result, there is large number of candidates who have successfully obtained teacher registration, but have yet to find employmenttherefore, the supply exceeds the demand. In Sri Lanka, the demand is determined jointly by the MOE and the provincial public service commission and the supply is determined by the number of graduates coming out of the National Institute of Education and the National Colleges of Education. Candidates graduating from other institutions such as the universities are usually not factored into the supply chain equation. Furthermore, recently in Sri Lanka, to appease unemployed graduates, the government accepted many arts and humanities graduates into the teaching force. This action undermined the teacher demand-and-supply planning process and has created an oversupply of social science teachers when there is a shortage of science, technology, engineering, and mathematics (STEM) teachers. ${ }^{9}$ The MOE now has to provide pedagogical training to all these recruits and, in some cases, training in science and mathematics to convert these new recruits to STEM teachers - this is an additional cost to the government and not a good strategy for improving the education system. All participating countries need to develop more strategic planning processes with less political interference to support improved teacher development and supply. The national central planning office, in collaboration with the planning division in the MOE, should be responsible for this task. If necessary, they may also partner with other local institutions (e.g., with universities and/or statistical agencies) that have capacity to undertake labor force demand analysis and forecasting. The national forecast has to correlate with the local demand captured in the teacher management information system (TMIS) or EMIS.

The student-teacher ratio (STR) is often used as proxy indicator of teacher demand and supply. The student-teacher ratio was initiated by the Education for All, Millennium Development Goals, and the Organisation for Economic Co-operation and Development (OECD) global programs to make class sizes in developing countries more manageable. While ensuring manageable class sizes is a good initiative, research suggests that lowering the STR beyond a particular threshold (35) is not a significant factor in improving student learning outcomes (Hattie 2008). The 2012 Programme for International Student Assessment results show that the 10 top-performing countries were not the ones with the lowest STR. Therefore, caution must be exercised when using only STR data for planning national teacher demand. Sri Lanka has a STR of 17:1, which is comparatively low when mapped against other countries globally. In Nepal, the STR is 31:1 for the primary level, 45:1 for lower secondary, and 31:1 for secondary (Nepal DOE 2012a). In Bangladesh, the STR is 43:1 at the primary level and 34:1 at the secondary level. The average number of students per institution is 216 in primary education and 394 in secondary education. The average number of teachers per institution is 5.0 in primary education and 11.7 in secondary education. The 2012 STR for primary education in Bhutan was 24:1 and 11:1 for Maldives (ADB 2014). Like Sri Lanka, Maldives data are very low by international standards. While the STR provides a first-level picture of national teacher demand and supply, it does not capture the problems of distribution between rural and urban schools or the subjectbased demand for teachers - thus, it masks the perennial disparity of high demand in rural

9 The MOE in Sri Lanka has the additional task of providing teachers in all subject areas and in national schools for both mediums of instruction, Tamil and Sinhala. 
schools when there is oversupply in urban schools. The push to lower the STR is often associated with perceived improvement of student learning outcomes but, as noted above, recent research shows that that may not be the case. However, it may help with classroom management. In many of the participating countries, classrooms in rural schools are often small in accordance with local village demand, which may also contribute to low STR.

\section{B. Teacher Database}

Over the years, with donor assistance, most countries in the region have embarked on some form of TMIS or EMIS that has a few subfields dedicated to teacher data. These information systems are at various stages of development and there are cases of competing datasets on teacher demand and supply. ${ }^{10}$ Unfortunately, some of the duplication is supported by the government, and this must be resolved to avoid wastage. There has also been a lot of discussion about the accuracy of the data collected by these information systems. It must be acknowledged that three of the countries in the region (Bangladesh, Sri Lanka, and Nepal) have very large teacher populations and will always have a margin of error; the task should be to minimize the margin of error within reason rather than expect a perfect dataset. It is important that the TMIS or EMIS have the necessary types of data and capacity to add data fields. Most countries have the capacity to produce national education statistics and develop basic tables for total number of teachers, gender distributions, STR, rural versus urban distribution, and teacher supply by district, village, and/or community. Capacity to collect accurate data from the field is only part of the solution; appropriate analysis beyond the basic routine reports to support policy formulation is equally important. This capacity is seriously lacking in all three countries. There is an urgent need to engage research professionals to help analyze and interpret the data for policy formulation. This can be done in-house or outsourced to universities or similar institutions that have the capacity. Disaggregated data for teachers in each country can be found in the national report in the appendixes.

Except for Sri Lanka where $72 \%$ of teachers are women, all other countries have made progress toward gender disparity in their teaching force. ${ }^{11}$ However, when considering disaggregated data (by subject, location, and type of school), there is still an imbalance in favor of male teachers in most of these countries. The gap becomes more significant in the higher levels of the education system. In Nepal, primary education has more female teachers whereas secondary education has more male teachers. The challenge of supplying teachers to rural schools is noted in various reports, but specific data on rural and urban schools are not readily available. In Nepal, teacher data are collected on a geographic basis and, in Sri Lanka, teacher data are based on national and provincial categories; however, teacher demand and supply information for rural and urban schools is often not collected. In the case of Nepal, the hill and mountain regions are often used as proxies for rural

\footnotetext{
10 There seems to be much duplication in databases. For instance, Bangladesh has the Bangladesh Bureau of Educational Information and Statistics plus EMIS cells in both the Department of Primary Education and the Directorate of Secondary and Higher Education. This is not cost-effective in terms of use of resources. In Nepal, the School Teachers Record Office also has a teacher database separate from the one being developed by the Teacher Service Commission and Department of Education.

11 See Sri Lanka Ministry of Education website. It must be noted that Sri Lanka also has to provide teachers to teach in English, Sinhala, and Tamil. A reverse gender equity policy to increase male teachers is needed in Sri Lanka.
} 
teacher data. As noted earlier, collecting basic data may not be sufficient-the capacity to dissect the data and run a more fine-grained analysis is necessary.

\section{Targeting Demand Forecast}

Targeting the planning and demand forecast requires a fairly accurate estimate of how many teachers are in the system, how many are in the pipeline, how many are needed every year, and how many may require reorientation training to eliminate mismatch. A good demand forecast system should be able provide the above information. ${ }^{12}$ Disaggregated data on teacher demand by subject specialization can help target teacher preparation to overcome shortage in some subject areas. The recruitment of untrained teachers by school management committees is an ongoing challenge. Again, disaggregated data by district and school may help identify areas where this ad hoc recruitment is occurring more so that those districts or schools may be provided appropriate advice. Similarly, analysis of performance of teachers trained in different types of preservice institutions can also help monitor the supply chain of quality teachers. Identifying training institutions that may need advice and support to strengthen their programs can help avoid redundancies and minimize retraining of poorly prepared teachers (including the untrained teachers that get into the system through the back door). These teachers have to be taken out of the system to retrain, which disrupts the planning of supply of appropriately qualified teachers. Capacity to undertake disaggregated and thematic analysis targeting specific issues, as noted above, has room for further capacity development.

To illustrate the planning challenges, in the academic year 2010/2012, there were a total of 158,213 candidates enrolled in preservice teacher education programs in various institutions in Nepal (UGC 2012). Of these, $48.4 \%$ were women, and this does not include those enrolled in the Higher Secondary Education Board programs. This supply chain is more than the projected demand for the same period. There are no disaggregated data on the areas of specialization of these preservice trainees; therefore, it is difficult to target actual demand. Furthermore, in Nepal, there are currently approximately 700,000 candidates who have successfully passed the teacher registration and are available to accept teaching appointments. Also, in large systems, there is often rent seeking, which contributes to inefficiency. For example, in Sri Lanka, the total number of teachers in the system is recorded as 219,886, of which 197,279 are actually working in classrooms. The rest are on deputation doing other work or on study leave. Similarly, in other participating countries, there are "ghost teachers" that add to the teachers' salary costs without providing additional benefit to the system. While the governments have been trying to resolve these inefficiencies, they have not yet been fully addressed and remain a cost burden. Random physical verification by school inspectors during their school visits is needed to monitor this, and sanctions should be imposed on head teachers and school management committees involved in this misrepresentation.

There is a perceived high demand for teachers that continues to fuel increased recruitment and training, but employment opportunity in the profession is limited. There is an urgent

\footnotetext{
12 In some countries, the government funds all preservice teacher training, and often, there are more trainees than the demand. Trainees' subject specializations are also not matched to the demand, resulting in oversupply of teachers in some subject areas and shortfall in others.
} 
need to reconcile the perceived vacancies with the actual vacancies. For instance, in 1990, the Nepal MOE advertised 14,000 teaching positions and attracted 200,000 applications, but only 86 candidates were selected (Shrestha 2008). This indicates both an unrealistic demand forecast and that qualified human resources are available in the country that can be recruited to support a robust, high-quality teacher supply system. The situation is similar in other countries in the region, and despite a ready pool of potential candidates, MOEs still invest money in preservice teacher training.

Primary education teachers in Bangladesh, and both primary and secondary school teachers in Sri Lanka, are recruited first and then sent on fully paid training. This means that apart from the training cost, the government also incurs salary costs for the years the candidates are in preservice training. This is a unique arrangement but not a wise strategy, particularly when both these countries have an oversupply of self-funded graduates looking for jobs. Selecting teachers from the already qualified graduates will significantly reduce costs and help streamline the process in line with international practices and practices in other professions. Teachers should be trained first and then recruited based on their academic and professional competencies. Rural and remote areas may be given some latitude with careful monitoring as "special cases," but a national policy to recruit first and then train on full salary does not make sense.

\section{Recruitment and Appointment of Teachers}

Appreciating the difference between recruitment of appropriately qualified teachers and appointment of teachers to a specific position is important. The latter usually happens from a pool of recruited candidates. In all participating countries, most teachers are civil servants (or government teachers), and thus the recruitment of teachers is often determined by civil service guidelines rather than teacher professional standards. Nevertheless, all countries have established some form of minimum academic and professional entry qualifications for primary and secondary teachers, but enforcing these requirements has been a challenge. Sri Lanka has adopted written tests and recently introduced interviews in the recruitment process to assess some of the soft skills to supplement the current very academically oriented test. Bangladesh also has a testing and interview system as part of the licensing requirement for primary teachers. Secondary teachers (only private school teachers) must pass an examination and be licensed. In Nepal, all teachers are required to be licensed through the Teacher Service Commission before they can be appointed to a teaching job. Since this is done through the Teacher Service Commission, it is applied only to government teachers. While there is general intention to improve and strengthen the current teacher registration and licensing in all countries, the technical knowledge and the political will to achieve this reform is lacking.

The large private sector participation in school education, particularly at the secondary levels, has resulted in a mixed policy framework for teacher recruitment and appointment. In Bangladesh, only private secondary school teachers need to register and obtain a teaching license. The government teachers, because they have passed the civil service requirements, are exempted. In Nepal and Sri Lanka, only government teachers can be recruited and licensed before they may be considered for a teaching appointment, whereas private school teachers have no such requirements. In both these countries, 
private school teachers are not subjected to the same regulations. A national recruitment and appointment policy framework should be applied consistently to both public and private school teachers, and to primary and secondary teachers. If circumstances force the appointment of a person without a license, then the policy framework should require the person to obtain a license within 12 months and submit it for endorsement. Such flexibility is useful for appointments in rural schools where teachers are often recruited from local candidates who may not have the license and registration.

Despite recent efforts by the respective governments to increase the entry requirements for primary teachers, it is still low, even though there is a huge supply of bachelor's degree graduates looking for work. In the majority of the cases, these unemployed graduates have funded their own education, which is not a cost to the government, yet there is a reluctance to recruit and appoint them and then provide some short, intensive postgraduate training. For secondary teachers, all countries require degree qualifications plus a registration to apply for vacancies; for primary teachers, in some countries the entry qualification is as low as grade 10 completion. ${ }^{13}$ Potential candidates with graduate qualifications will have higher levels of cognitive ability, academic knowledge, and life experience than the recruits who have merely completed grade 10 or 12 . Furthermore, keeping the entry requirements so low devalues the profession, making graduates unwilling to apply for such low-level jobs. It may be prudent to raise the entry requirement and then adopt a case-by-case approach for rural areas where it may be difficult to attract graduate teachers. For many of the unemployed graduates, it is often not the salary (many have no jobs) - rather the respect and working environment that can make teaching an attractive employment choice. Setting the entry requirement to the lowest common denominator makes teaching an unattractive, lowstatus job, particularly for graduates.

Appointment of teachers to specific positions is done through a mix of decentralized and centralized systems. ${ }^{14}$ This is because in some countries, like in Sri Lanka, there are schools that are governed by the central government, so the teachers are appointed by the governing authority or the national teacher appointment system. The inability of the central system to supply teachers in a timely manner to all schools in the country, and the need to empower local communities to take more responsibility for their schools' performance initiated the need for teacher appointment to be handled by local authorities. While the concept of empowering local ownership regarding their staffing is progress in the right direction, it has not worked as well as anticipated. The political capture of the school management committees and the nepotism and corruption of the local power brokers have undermined the process, resulting in continued appointment of unqualified teachers. ${ }^{15}$ This, in turn, continues to create a demand for extensive in-service training. Implementing teacher recruitment policies, particularly the minimum entry qualification, has been a challenge for all participating countries. In Nepal, the Teacher Service Commission does the recruitment, licensing, and appointment of permanent and temporary teachers for all community schools. In community-managed and institutional schools, the school management committees make the appointments. Sri Lanka has a mix: both the provincial

\footnotetext{
13 See Chapter IV of this report for a detailed discussion.

14 The Education Act (7th Amendment, 2001) has provided two types of recruitment system for the schools of Nepal.

15 To develop a system that has high-quality teachers requires political will to enforce national policies across the country.
} 
public service commission and the central MOE make appointments but the recruitment and licensing is done by the MOE.

Nearly all teachers desire to become civil servants because of the attractive employment conditions and security. As a result, teachers often take up rural appointments to join the civil service, but as soon as they are confirmed as civil servants they seek transfer to the cities. This creates two problems: (i) it is difficult to find teachers who want to go the rural areas even when they are offered civil service positions; and (ii) the civil service quota for rural schools are filled by teachers who move back to urban schools. It may be worth considering assigning the civil service status to the position at the school rather than to the teacher. That way, a teacher will be a civil servant only while working at the rural school. This will make it attractive for candidates from the rural areas who have more reasons to remain in the rural community.

\section{E. Various Categories of Teachers and Job Differentiation}

Apart from the usual challenges faced by countries to manage the demand and supply of trained teachers - such as attracting teachers to rural and remote schools, enforcing the minimum recruitment policies, and maintaining equity and gender balance-some of the participating countries have additional issues to deal with. For instance, in Sri Lanka, instruction is provided in three different languages, which means you need to provide primary and secondary teachers with necessary subject specialization for each of the three mediums of instruction. In other words, since one teacher having three language expertise is not readily possible. Hence, they have three sets of teachers-one for each medium of instruction. In Nepal, while the language of instruction may be common, the varied conditions of employment for community teachers, community-managed teachers, rahat (relief) teachers, per-child fund teachers, and school-funded teachers (supported by local fund-raising) create added complexity in managing demand and supply. ${ }^{16}$ Some may be employed only for one school term. Similarly, in Bangladesh, there are government, nongovernment, madrasah, monthly payment orders, Bangladesh Rehabilitation Assistance Committee (BRAC), plus other types of teachers with varying conditions of employment. The temporary employment status of many of these teachers, whose positions depend on "soft money" or money from local fund-raising or international nongovernment organization (NGO) and NGO support, which could be short term or only for a single school term, make it difficult to manage the supply. As noted in the various country reports, the data on many of the categories funded by soft money are not captured in the national

TIMS despite often accounting for a substantial percentage of the total number of teachers in the system.

Another category, untrained teachers, still exists in large numbers despite significant government efforts to stop the appointment of untrained teachers. For instance, in 2009, the Nepal Department of Education made a special effort to provide training to all untrained teachers in the system so that the new recruitment policy could be successfully implemented. However, there is a new cohort of untrained teachers in the

16 In 2012, there were 202,594 teachers in community schools (equivalent of government schools). 
system mainly due to noncompliance by the school management committees when making appointments. Similar practices can be found in Bangladesh. If the appointment policies are complied with, then the constant need to train untrained teachers will be resolved and considerably reduce the amount of in-service and continuing professional development (CPD) training needed. There should be sanctions for noncompliance, such as making government subsidy subject to meeting the agreed requirements, which could be teacher performance targets or ensuring untrained teachers obtain registration within a certain time.

\section{F. Teacher Performance Monitoring}

Teacher performance monitoring is often confused with school inspection, which reviews largely administrative functions. Most participating countries have inspection systems where inspectors from the central and provincial, district, or subdistrict levels visit schools to monitor school performance, of which teacher performance is a small subset and often happens vicariously. Initiatives such as the minimum service standards and whole-school improvement plans focus on supply-side indicators: the health and safety of school environments (physical infrastructure and sanitation), number of teachers and textbooks available, teacher and student attendance, and other administrative matters. While these initiatives are important, they do not specifically target teacher performance. For example, Sri Lanka has established the Management and Quality Assurance Board and a school education quality index that targets whole-school improvement, but teacher performance monitoring is not a specific quality indicator. Teacher performance should focus on demonstration of mastery of subject content and use of appropriate pedagogical techniques in the classroom. Performance monitoring should be linked to student learning outcomes and not just targeting inputs (Smeed 2013). If inputs do not achieve the desired outcomes, then the inputs may have to be revised.

Furthermore, the concept of teacher performance monitoring as a separate and important indicator linked to the national teacher standards should be strengthened and made explicit. ${ }^{17}$ Currently, the teacher performance standards embedded in school inspections are understandably targeting administrative and teacher character issues using checklists. These inspectors do not have the time nor the resources (travel costs) to make regular inspection visits to monitor teacher performance. Visiting rural and remote schools is particularly difficult and often gets neglected. Despite the move to decentralize the management of school education, there is still more to be done to fully appreciate what is involved in a decentralized teacher performance management system, and the best options for implementing a workable arrangement.

In some countries, teacher performance monitoring has been passed on to the school head teachers. This approach has been successfully implemented in many OECD countries and in many private schools in developing countries. ${ }^{18}$ In the institutional schools in Nepal, the

\footnotetext{
17 See Chapter IV for details on how national teacher standards are intrinsically linked to teacher performance monitoring. Constructive alignment between national teacher standards, teacher training programs, and teacher performance in the classroom is yet to be fully appreciated and institutionalized.

18 In Australia, the State of Victoria has devolved all school administration and management to the school principals including monitoring performance, appointment, and termination of teachers. Similarly, in the United
} 
head teacher monitors the performance of teachers and makes recommendations to the school management committee. In Nepal's institutional schools, particularly the secondary schools, teachers tend to produce better student achievement results despite having much lower in-service and CPD training. Similarly, in Sri Lanka, in private schools such as Gateway College, regular teacher performance monitoring is an internal institution-level activity managed by the school principal, and the recommendations are passed on to the school board for action. The excellent performance of Gateway College schools has created a 3-year waitlist for new students. The performance of individual teachers collectively manifests as school performance. The nongovernment schools must be doing something well that the public system can learn. Thus, there is a need to facilitate more knowledge sharing between the private and public sector teacher performance monitoring systems.

Head teachers are in the best position to judge teachers' performance in the classroom on a regular basis instead of school inspectors on annual or term visits. ${ }^{19}$ Also, since the head teachers are accountable for school performance (one core indicator is student achievement), they have a vested interest in knowing their teachers' strengths and weaknesses so that they may maximize teachers' contribution to improve student learning outcomes and, consequently, school performance.

It must be acknowledged that school-based teacher performance monitoring increases the workload and intensity of engagement of head teachers or subject heads of departments who may sometimes act as proxies of head teachers. In the countries in the region, the role of the head teacher has not been fully appreciated and often it is an additional responsibility tagged on to full teaching duties. In light of the above, consideration should be given to developing a separate career path for head teachers, with appropriate salary structures and a clear staff development plan with performance linked to school improvement and student achievement. It will require clearly describing the teacher performance indicators (which should be linked to national teacher standards) and providing sufficient training to the head teachers. Head teachers should be able to use their school performance data and advise teachers on areas of low performance by school and by class. Adopting school-based teacher performance monitoring also requires a mature decentralized system where the head teachers can honestly and effectively perform this task.

Trials of school-based teacher performance monitoring are being conducted in Bangladesh primary schools through the school-level improvement plans, with mixed results. Lessons learned suggest that for this to be fully effective, significant capacity building is necessary for head teachers as a separate career path (but originating out of the regular teaching force) and for school management committees to appreciate what constitutes teacher performance. Also, it is evident through the current experiences that some checks and balances may be required to mitigate against risk of nepotism and other unethical practices at the local level in some of the participating countries.

Kingdom, many public schools are managed by boards that have full autonomy to plan and manage schools. These schools adopt a performance-based management approach, wherein teacher performance is linked to school performance.

19 Various World Bank and Asian Development Bank reports have noted that district-level teacher monitoring systems established through donor support are not working because governments are unable to meet recurrent costs associated with travel. In some countries, the school inspector positions are vacant because of budget constraints. 


\section{G. Conditions of Employment Adopted by Countries in the Region}

As noted, there are various categories of teachers in South Asia with varying employment conditions. The majority of primary teachers, and a large percentage of secondary teachers, in all the participating countries are government teachers, so they have the typical civil service conditions (government salary, pension benefits, various leave options, sick leave and medical benefits, and time-based incremental promotions). ${ }^{20}$ These entitlements are the biggest motivations to join the teaching profession. Even though the conditions of service for government teachers are used as a default benchmark, teachers from other categories are not as fortunate. Temporary teachers, or government-assisted teachers, in theory should have the same employment conditions as government teachers, but, in reality, this is not always the case. Perhaps the most demotivating aspect is not the salary but the delays in paying these teachers - in some countries, teachers may wait up to 3 months to be paid.

The government teacher salary structure is stratified based on qualifications, teaching grade levels (salaries of primary teachers are lower than those of secondary teachers), and teacher category. There are several levels within each salary scale, and progression along the scale should be seen as a means of rewarding high-performing teachers. Unfortunately, in many of the countries in this region, pay raises are time-based, not merit-based. Other incentive schemes were introduced to attract more females in the system and teachers destined for rural and remote schools. The limited number of levels (3 or 4 ) in the career paths can be demotivating; this may be expanded to incentivize teachers to continue to perform at high levels as they seek further promotion.

The entitlement of CPD and in-service training as a condition of employment requires serious review, as these should be adding value to the professional competency of teachers. Currently, this has become a "training industry" with little value added. While appropriately trained and well-qualified teachers are necessary, there should be more efficient and effective ways to achieve this instead of repeating the same training every year. Cluster-based training and training provided by resource centers, education training centers, teacher training colleges, and so on are a huge investment of money and time by the respective governments, but the impact is mixed. Also, during these training programs, children in schools are often left without teachers-so the actual beneficiaries of the teacher training may be worse off. It is important to find better ways to support CPD training without jeopardizing children's learning opportunities.

20 The Sri Lankan Teachers Service and the Teacher Civil Service in Nepal manage all the entitlements for government teachers. 


\section{TEACHER QUALITY ASSURANCE}

he function of the national teacher professional standards is pivotal to improving
teacher quality. It informs the following:

(i) preservice training providers (universities and training institutions) about the expected scope and content of the teacher training programs;

(ii) the design of the teacher licensing and registration evaluation process;

(iii) the teacher performance monitoring division about which areas are important and require monitoring;

(iv) the analysis required for monitoring data to determine limitations in the current standards and procedures which feeds back into the loop to review and update the preservice programs or develop continuing professional development (CPD) training to bridge the gaps; and

(v) the design of all in-service programs, which should be linked to the standards to explicitly illustrate how each program adds value to teachers' professional development. This includes training provided by international and domestic nongovernment organizations (NGOs). In-service training should show how, and which, teacher professional standards indicators are being targeted by the training. Considering the huge volume of in-service and CPD training provided in the region, such explicit articulation with the professional standards will significantly help reduce duplication and wastage.

\section{A. Minimum Quality Standards and Quality Monitoring}

Currently, there seems to be mixed understanding of what constitutes a national teacher quality assurance system. Particularly, there is confusion between teacher professional standards and competencies and teacher management. The latter focuses on recruitment and career paths (minimum entry requirement, employment conditions such as civil service entitlements, salary levels, incentives, and rewards attached to time served or qualifications acquired, etc.). ${ }^{21}$ Teacher professional standards focus on the knowledge, skills, and dispositions a professional teacher should demonstrate in the classroom, including teaching

${ }_{21}$ In Nepal, there are 13 different categories of teachers; some are based on the funding arrangement, some on the conditions of employment, and others on qualifications. Managing these categories of teachers is related more to supply and civil service management than to teacher professional standards. In Sri Lanka, the Ministry of Education (MOE) has established the Management and Quality Assurance Branch, which evaluates schools and teacher education institutions under the ministry. 
subject content plus pedagogical content. ${ }^{22}$ Given the diverse capacity required of current teachers to effectively perform their duties, caution must be exercised not to overwhelm the system and alienate stakeholders when setting standards. The contemporary researchand evidenced-based practices should inform the formulation of minimum teacher professional standards.

Most Association of Southeast Asian Nations (ASEAN) member states either have a national teacher professional standard or are in the process of establishing one. An ASEAN-commissioned study (Valenzuela 2010) conducted an audit of 11 ASEAN member states. Among the audited countries, most focus on pedagogical skills only; the exception is Singapore, which also considers "mastery of subject content" as an integral part of the teacher professional standards. Internationally, most countries have developed national teacher standards or competency frameworks (see, e.g., Australia, Malaysia, Scotland, and the United Kingdom) ${ }^{23}$ India has adopted a slightly different approach. It has developed a national curriculum for teacher training in which all the key professional competencies and standards are embedded. ${ }^{24}$ Unfortunately, like most ASEAN member states, these national teacher standards do not consider subject content knowledge as part of the standards framework. Recent studies show that lack of sufficient subject content knowledge by teachers, particularly in science, technology, engineering, and mathematics, is influencing poor student performance in these subjects. This perhaps reflects the lack of consideration given to mastery of subject content knowledge in the national teacher standards.

Requests for demand-based teacher training in most of the countries in the region are largely for subject content knowledge and skills. This illustrates the risk of not adopting a holistic approach to developing teacher standards and competencies and just focusing on pedagogical aspects. The volume of in-service training targeting subject knowledge can be significantly reduced if the minimum teacher standards included subject content knowledge for all school subjects, as it is more likely for training providers to be explicitly covering these during the preservice training.

Having a national teacher standards framework increases the transparency of teacher quality monitoring. The Australian Institute for Teaching and School Leadership (2011) and its partners are promoting national implementation of the standards through several initiatives including

(i) accreditation of initial teacher education programs in Australia,

(ii) a nationally consistent approach to teacher registration in Australia,

(iii) certification of highly accomplished and lead teachers in Australia,

(iv) the Australian Teacher Performance and Development Framework,

(v) the Australian Charter for the Professional Learning of Teachers and School Leaders, and

(vi) the development of support materials and resources.

\footnotetext{
22 The terms "standards" and "competencies" are used interchangeably in this study.

23 See Government of Malaysia, Ministry of Education website; United Kingdom, Department of Education website; Australian Institute for Teaching and School Leadership (2011); India National Council for Teacher Education (2009); and General Teaching Council for Scotland (2012).

${ }^{24}$ See India National Council for Teacher Education (2009) and website.
} 
The design of preservice teacher training has to ensure all the competencies are met through the subjects included in a teacher training program. Training institutions that do not comply should be advised that their graduates will not qualify for teaching jobs. In India, the National Council for Teacher Education sanctions institutions that do not comply with minimum standards. The council's website informs the public of the institutions that are accredited to offer certain types of teacher education programs. Apart from using the national teacher standards for monitoring the training providers, teacher registration should also adopt the minimum standards as a means of granting registration to those who can meet the standards. That way, the importance of the minimum national standards is reinforced. Furthermore, in-service and CPD programs should be able to clearly articulate which competencies are being addressed by the training. Demand-based training should also be able to clearly point out what aspect of the national teacher standards or competencies the particular demand-based training is responding to. Figure 2 illustrates the interdependency of a national teacher standards framework (NTSF).

Qualifications required for licensing should be judged against the national standards. Qualifications may be accepted at face value assuming the training programs are compliant with national teacher standards. However, this assumption has been shown to be lacking.

\section{Figure 2: Interdependency of a National Teacher Standards Framework}

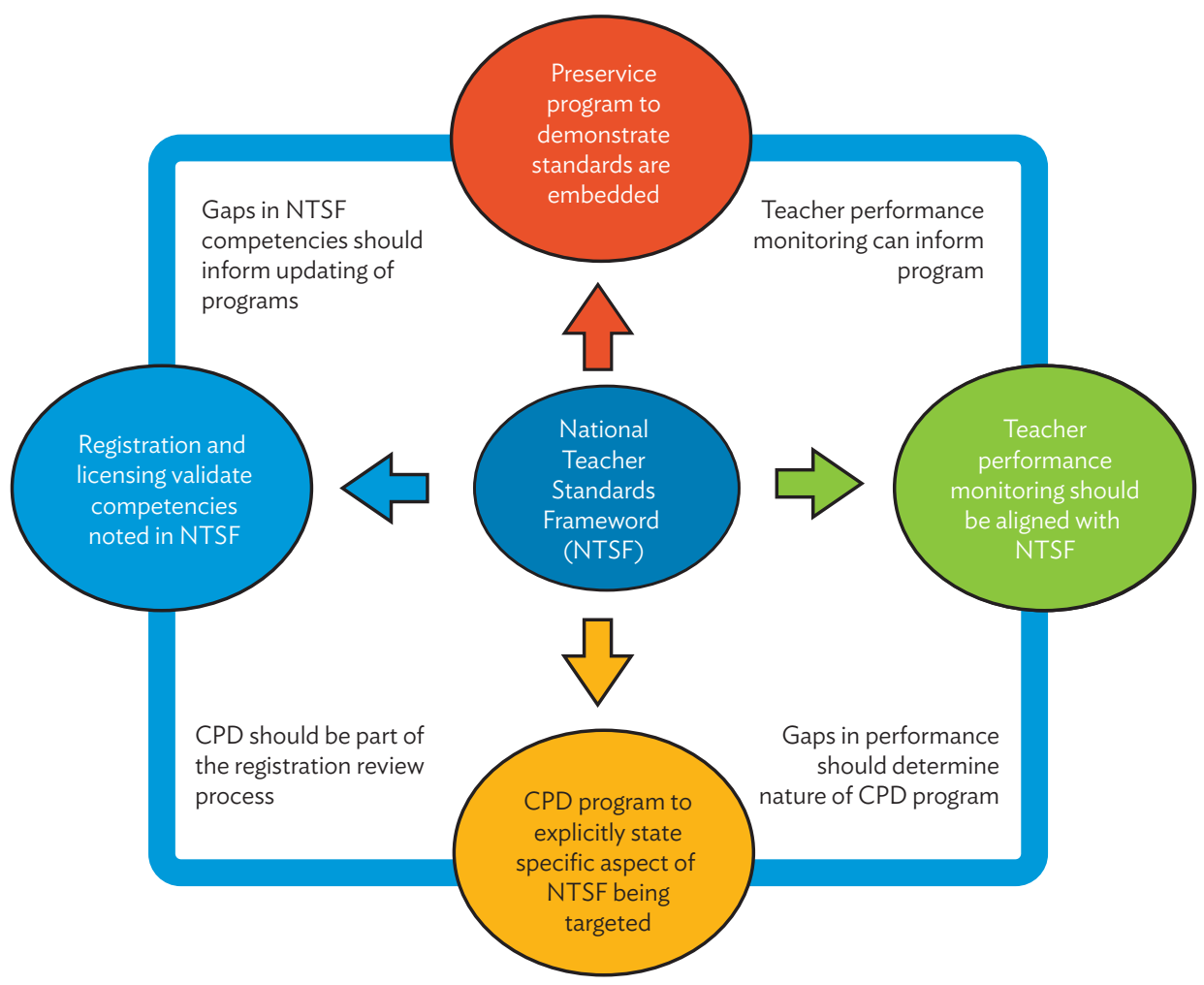

$\mathrm{CPD}=$ continuing professional development.

Source: Author's illustration. 
Hence, there is a need to set up a licensing or teacher registration process to provide a first-level independent check to see if the training institutions are preparing teachers appropriately. Teacher licensing can be done in several ways: evaluation of professional portfolios illustrating demonstrated outcomes against the teacher standards, formally testing against the national teacher standards, interviewing teachers, or a mix of these options..$^{25}$ As a feature of the national teacher quality assurance system, the teacher registration requirements should be applied consistently to all teachers in the country-it cannot discriminate against any one group. In Nepal, teacher licensing does not currently apply to private school teachers, whereas in Bangladesh it applies only to secondary private school teachers, and all others are exempted (madrasah, government secondary teachers, all primary teachers). In Sri Lanka, licensing is applicable to government teachers only. This is contrary to the inclusive education policy adopted by the three countries.

Furthermore, in most professions, a professional license and registration must be renewed after a certain time frame to ensure currency of knowledge and skills. In professions such as medicine and law, members are expected to take a certain number of hours of approved CPD training. However, in the region, the renewal of a teaching license is designed as another test after 3-5 years. Tests are not the best option and are not able to demonstrate the professional competency of teachers. Therefore, for renewal of registration, alternative mechanisms that link the national standards directly to classroom practice should be considered. This will motivate teachers to engage in self-development. In some countries, "teacher professional portfolios" are used to supplement the evidence of their professional competencies during license renewal.

Similarly, continuous teacher performance monitoring should focus on the application of national teacher standards in the classroom. How are teachers applying the standards in the classrooms? If the standards are not achieving the desired outcomes, then consideration must be given to what modifications to the standards may be required. The continuous reinforcement of national teacher standards helps institutionalize their significance. Since national standards are developed and documented, and all training programs are aligned with national standards, the monitoring of teacher performance should be linked to the standards, which in turn should help improve student learning outcomes. The current practice of having school inspectors (or equivalent) travel to schools for occasional inspections is not working in most of the participating countries for various reasons.

Some private teacher training institutions have formed partnerships with international training institutes, and therefore undertake international benchmarking. ${ }^{26}$ Twinning arrangements with selected international partners can significantly help local teacher training institutions adopt international practices and engage in contemporary research. Currently, there is very little sharing of knowledge and experience within the countries, across the region, or internationally. Sri Lanka has initiated a regional center for education with support from a second-tier United Nations Educational, Scientific and Cultural Organization center. It is in the early stages but has the potential to provide a platform

\footnotetext{
25 Most of the countries involved in this regional technical assistance study have introduced teacher registration and licensing mechanisms based mainly on an academic test. There is ongoing debate about the nature of this test and what it measures.

${ }^{26}$ Gateway College in Sri Lanka has a partnership with Edexcel from the United Kingdom. Gateway College started with a Diploma in Education program that it is now upgrading to a bachelor's degree.
} 
for regional and regional benchmarking and knowledge sharing. The MOE has provided infrastructure space and an operational budget.

\section{B. Institutional and Organizational Arrangements for Quality Monitoring}

Typically, a quality assurance system is embedded with some form of legislation that gives the authority to enforce the quality requirements. It also allows mechanisms for appealing a decision of the quality assurance agency through an alternative process (through the judicial system) instead of going to the same quality assurance organization that made the initial decision. From a functional perspective (Figure 3), a national teacher quality assurance system should have a body that sets the minimum standards and competencies for primary and secondary teachers; a body that regulates and monitors compliance with the minimum standards; and, finally, service providers (training institutes or agencies) that respond to the minimum standards when designing and delivering their programs. It is important to separate these agencies, wherever possible, to avoid conflict of interest and to have periodic third-party audits as well. Having national minimum standards for primary and secondary teachers provides a powerful basis for managing and monitoring all aspects of teacher development and performance monitoring.

Figure 3: Key Functional Elements in a Quality Assurance System

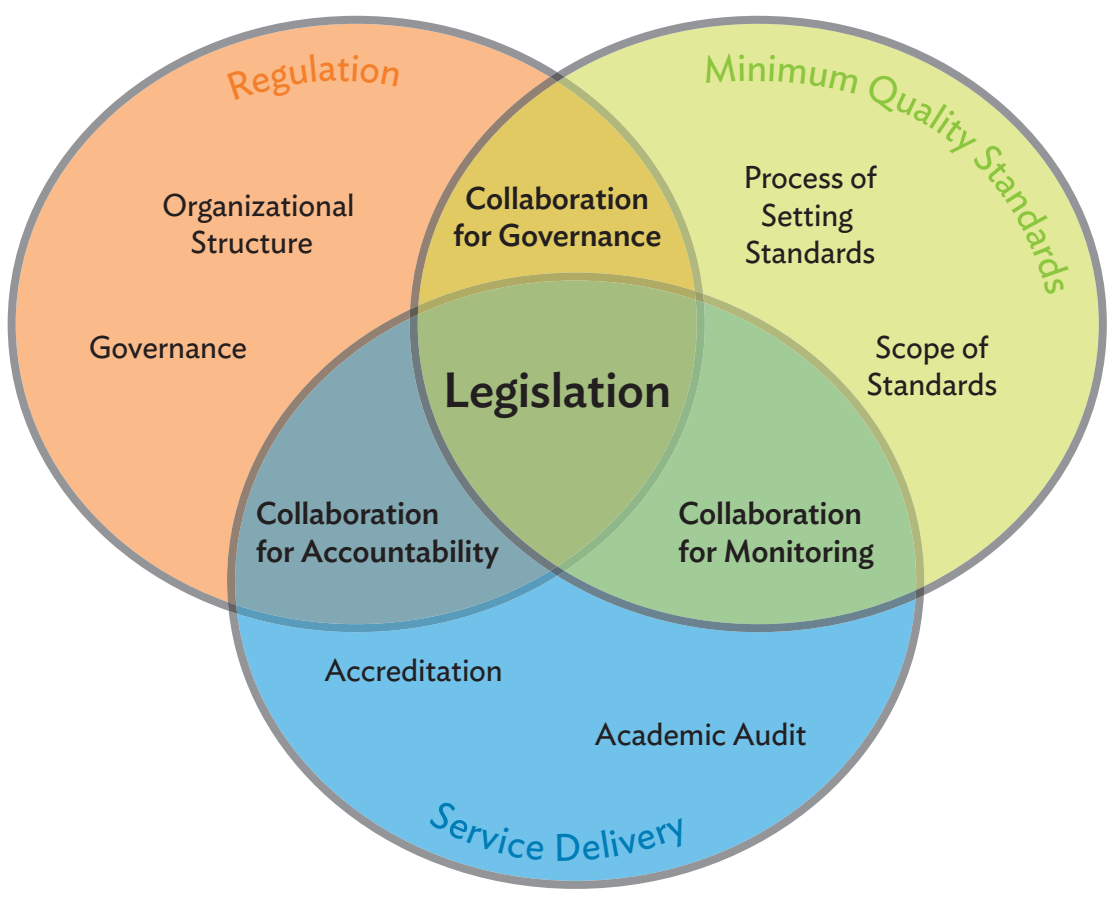

Source: Author's illustration. 
The ongoing support of donor partners has stimulated consideration and design of a systems approach to teacher quality assurance and monitoring. In Bangladesh, Nepal, and Sri Lanka, institutional and organizational arrangements are being established to set national standards and monitor teacher performance, which will be gradually strengthened. Monitoring teacher performance from the central MOE in these diverse and dispersed systems will always be a challenge. Periodic audits of the program will be necessary to ensure compliance by the training providers, a task that may be delegated to district education offices. ${ }^{27}$ Cognizant of the above, the governments have embraced decentralized models with varying degrees of success. Bangladesh is moving toward a school-based teacher performance monitoring model using school-level improvement plan mechanisms, whereas in Sri Lanka, the district-level school inspectors tend to fulfill this role.

There is a tendency to rush to infrastructure and organizational development rather than develop a quality assurance system based on functions and responsibilities that is supported by qualified technical staff to perform the tasks. For instance, developing national teacher standards and then monitoring their impact on teacher quality improvement is a full-time job for appropriately qualified personnel. The current practice in most of the participating countries - of appointing senior managers from the general government cadre to establish and manage a quality assurance system, supported by deputized personnel-may not be the best strategy.

Also, the practice of attaching the quality assurance role to existing organizations that have a very different mandate further complicates the establishment of a rigorous quality system. In Sri Lanka, the government has established the Management and Quality Assurance Branch as a department within the MOE. It focuses mainly on infrastructure, facilities, and supply of resources, including teachers from an equity and input perspective-supply side. It does not consider teacher quality improvement or teacher performance monitoring. In Bangladesh, the National Academy for Education Management was selected as the apex body for secondary teacher quality improvement and the National Academy for Primary Education for primary teacher quality improvement. Both these organizations have mandates other than quality assurance and, as such, do not have staff with appropriate qualifications. To overcome this, staff are deputized to get the work done, but this is not sustainable and there is little ownership of the quality assurance system. A more strategic approach is needed to establish an organizational structure with clear functions and dedicated personnel to ensure a robust and well-functioning teacher development and performance monitoring quality assurance system. In Nepal, the role and function of the Teacher Service Commission and the National Center for Educational Development overlap, which creates confusion and, consequently, lack of accountability regarding who should develop and implement the NTSF.

\footnotetext{
27 Since teacher training institutions are considered higher education, it will be prudent to link the teacher quality assurance systems with the University Grants Commission, which oversees university governance and quality matters. If there are procedures in place for periodic review of universities, it will be wise to use a similar approach, instead of creating yet another level of bureaucracy. Also, many of the universities are involved with teacher training so it will streamline the process.
} 


\section{TEACHER TRAINING PROVISIONS}

T here are different types of institutions that provide teacher training programs in the region. Traditionally, all primary and secondary teacher training has been through public teacher training colleges (TTCs), which are part of an education ministry or department. As programs were upgraded to offer undergraduate and postgraduate degrees and diplomas, the teacher training institutions rebranded themselves and formed a parallel system of higher education to the university systems in each country.

\section{A. Teacher Training Institutions}

In Bangladesh, the primary teacher training institute (PTI) is under the governance of the Department of Education and the certificate issuing authority is the National Academy for Primary Education. ${ }^{28}$ The secondary teacher training institutes in Bangladesh-TTCs and higher secondary teacher training institutes - are governed by the MOE and are under the National University, which functions as a statutory board that has authority to issue degrees. Then there is the Bangladesh Madrasah Teachers' Training Institute, which trains madrasah teachers and offers degrees through the Islamic University. ${ }^{29}$ In Nepal, the National Center for Educational Development recently offered a one-off certificate in teaching to train all untrained teachers, but how that program articulates with any other programs in the country is not clear. The preservice training happens through the Higher Secondary Education Board and affiliated colleges that offer degrees outside the university system. In Sri Lanka, there are the National Colleges of Education that offer diploma-level programs, and the National Institute of Education that offers degree and postgraduate programs. These two institutions in Sri Lanka come under the governance of the MOE and not the university system.

Apart from the above noted institutes, the university systems in the region also provide preservice teacher training for primary and secondary teachers. Universities, through their faculties of education or affiliate institutes, ${ }^{30}$ provide both primary and secondary

\footnotetext{
28 The function of the National Academy for Primary Education has changed so many times that it is difficult to develop a long-term sustainable system. Most recently, there has been discussion to negotiate with the Institute of Education Research at Dhaka University to issue the Diploma in Education (primary) offered by the PTIs. While this may not be good for the academy, it allows the primary teacher training program to be articulate with university degree programs.

29 The Bangladesh Madrasah Teachers' Training Institute is considered an affiliate institution of the Islamic University.

30 In Nepal, Tribhuvan University has over 1,000 affiliate colleges with varying levels of physical facilities and quality. In the absence of any higher education quality monitoring system, these affiliate colleges are popping up everywhere and in recent years have become a concern for the higher education sector.
} 
undergraduate programs to new candidates as well as postgraduate programs (master's, postgraduate diplomas, and postgraduate certificate) to candidates who have completed an undergraduate (BA or BSc) degree and wish to become a teacher. In Bangladesh, the recently designed Diploma in Education (primary) was initially intended to be delivered through the PTIs. However, the PTIs' limited capacity creates a major bottleneck in the system. Consequently, institutes such as the Institute of Educational Research are now being considered for delivery and accreditation of the program. This change can be expanded to other quality-assured universities throughout the country. Twinning PTIs with universities will help improve the quality plus increase the supply throughout the country. PTIs can concentrate on in-service and continuing professional development (CPD) programs, while preservice training can be delivered by quality-assured universities throughout the country.

Similarly, there are facilities and institutions to deliver in-service and CPD training spread all over each country. Capital costs for most of these were met through donor support, but staffing and maintenance were the responsibility of respective governmentsunfortunately, they have not been very forthcoming. Despite the large number of institutions and universities already available in all the countries, access to teacher training opportunities still seems to be constrained. ${ }^{31}$ The highly controlled approach to providing teacher training prevents full utilization of the existing teacher training capacity in each country.

The majority of teacher training institutions are underutilized, poorly maintained, and represent an ongoing cost to the government. For instance, despite being called "resource centers," many of these facilities do not have any teaching and learning resources or library materials. There is an urgent need to undertake a utilization study of these facilities. Instead of building more infrastructure, it will be prudent to (i) procure some teaching and learning resources to make these facilities into actual "resource centers," and (ii) strategically phase the training to ensure the facilities are used throughout the year and not just for few weeks. In Nepal, there has been some discussion between the University of Kathmandu and the Department of Education about the possibility of using of some education training centers as information and communication technology (ICT) training hubs or for distance learning centers by the university for a fee-which is perhaps better than keeping the training centers closed.

Apart from the publicly funded teacher training institutions, there are some private providers as well. These are a mix of private universities, private TTCs (in Bangladesh), plus private providers who train teachers for their own school community-such as BRAC University's Institute of Education Development in Bangladesh. In Sri Lanka, Gateway College schools have their own teacher training; in Nepal, Rato Bangala School trains its own teachers. The private sector teacher training may be small, but they have the autonomy to experiment with innovative practices. Unfortunately, there is little interaction between the public and private teacher education institutions in the region.

31 In Sri Lanka, there are over 200 institutions and facilities (National College of Education, teacher centers, regional English support centers, computer resource centers, provincial ICT centers). In Nepal, the education training centers and resource centers make over 100 facilities. Bangladesh has resource centers in every upazila (subdistrict) and more are planned. 
There may be sufficient institutional facilities in all the countries in the region to train teachers to meet the current annual demand; therefore, further investments in teacher training infrastructure may not be the best approach to improve the quality and supply of teachers. Alternative options, such as partnerships and twinning arrangements with existing institutions through some quality assurance mechanism, may be more efficient and effective. Also, having a national teacher standards framework (NTSF) provides a basis for managing the quality of programs across all training providers so the type of institution is not the focus-it is the quality of the program that matters, not who delivers it. The focus is on offering the best program, which can be provided by a consortium, partnership, or twinning arrangement between universities and TTCs. For instance, as noted earlier, the Diploma in Primary Education program in Bangladesh may be offered by any institution that satisfies the minimum quality requirements for service providers. That way the pressure on PTIs and the consequential bottleneck thus created will be resolved without large infrastructure investments.

\section{B. Teacher Training Programs}

The structure and content of teacher training programs varies within each country. The Bologna Declaration on higher education and the United Sates conventions for university programs provide frameworks for developing higher education program structures that progressively map knowledge enhancement and capacity development from year 1 to year 4 for a 4-year program. ${ }^{32}$ Such a framework can provide international and regional benchmarking, which is not currently possible given the diversity in program structures and durations used by countries in the region. The Australian Qualifications Framework provides a detailed articulation of postsecondary education qualifications using knowledge, skills, and applications as units of assessment. ${ }^{33}$ The Australian framework covers the entire higher education subsector, which includes teacher education. A single framework for higher education is more easily understandable and accessible to all stakeholders. The parallel systems ${ }^{34}$ currently seen in Bangladesh and Sri Lanka do not help in the development of robust and consistent teacher training programs.

\section{Structure of Program}

The core training (which in some countries is treated as in-service) for primary education could range from a 9-month intensive teaching certificate to a 4-year bachelor's degree in education, and in secondary education, from a diploma in teaching to a master's in education. Teacher training programs globally typically have four distinct parts: the subject content, the pedagogical content, the practice teaching, and some general education (Figure 4). The workload or time allocated to each part varies, but as a rule of thumb there is a 50/50 divide between the subject content and pedagogy (which usually includes general education and teaching practice). For primary teachers who do not have subject

32 See Benelux Bologna Secretariat (2007-2010).

33 See Australian Qualifications Framework Council (2013).

34 In Bangladesh, the primary teacher institutes are trialing an 18-month-long Diploma in Education program. At the same time, Bangladesh Open University and the Institute of Educational Research are offering 4-year Bachelor of Education (BEd) degrees for primary teachers. In Sri Lanka, there is a 2-year teacher training certificate, a 1-year diploma in teacher education primary, and a 3-4-year bachelor's degree. Nepal has 1-year and 3-year programs leading to a BEd degree. How these programs progressively map teachers' knowledge and skills as per the national standards and provide credit for previous qualifications is unclear. 


\section{Figure 4: Typical Structure of Teacher Education Program}
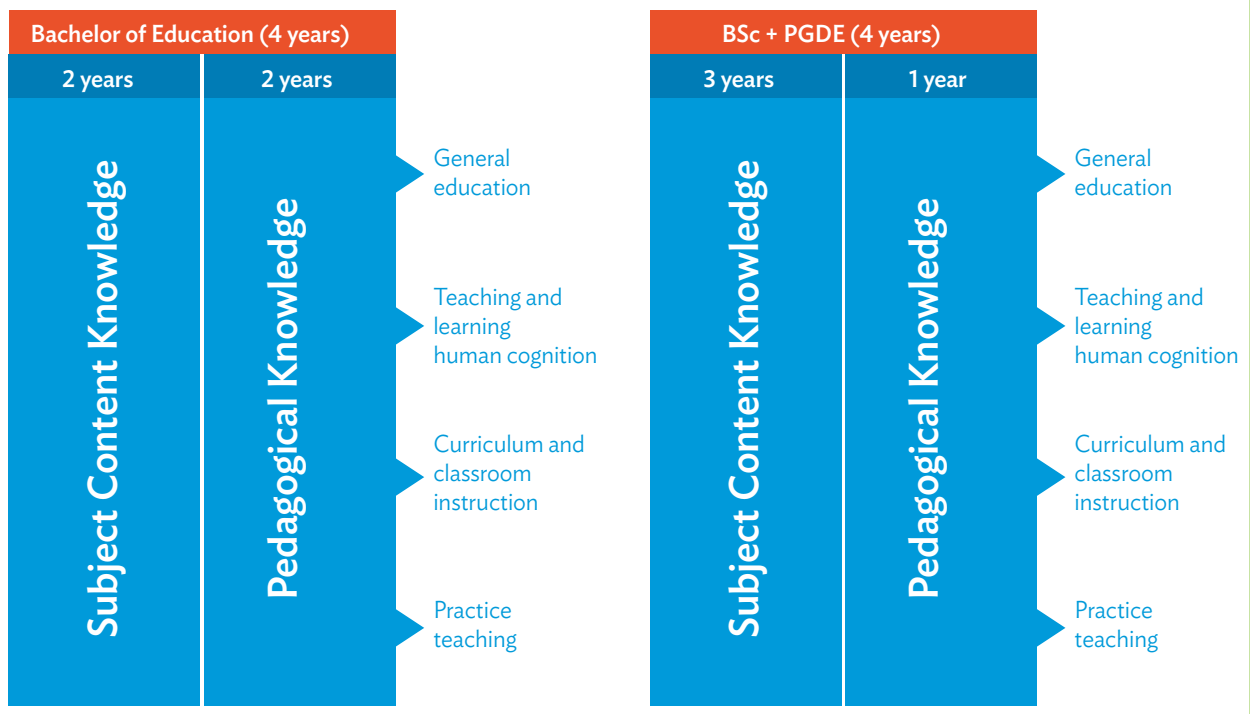

$\mathrm{BSc}=$ Bachelor of Science, $\mathrm{PGDE}=$ Postgraduate Diploma in Education.

Source: Author's illustration.

specialization, the time or workload allocation for subject content is spread over all the core subject areas.

Unfortunately, most TTCs in the region overemphasize pedagogy content, which has resulted in high demand for subject-based in-service training. ${ }^{35}$ To correct this deficiency, the preservice training should be reviewed. Lessons from Singapore, which has a very robust school education system, should be heeded and teacher training programs should consider the mastery of subject knowledge. The total knowledge and skills the teachers require to professionally discharge their duties should be included in the national teacher standards. The assumption that new teachers have sufficient subject content knowledge when they begin training may need review, particularly when, in some cases, the prerequisite for entry to primary teacher training is as low as grade 10 pass for females and grade 12 pass for males.

Furthermore, the structure must also ensure that the program allows enough time to meaningfully cover all aspects of the national teacher standards and how that content coverage maps the cumulative credit recognition as the teachers progress to higher qualifications. ${ }^{36}$ For instance, if a diploma in primary teacher education is a 2-year program, then how does that align with the 4-year Bachelor of Education (BEd) in primary teacher

\footnotetext{
35 This may be partly due to the current understanding of national teacher standards and competencies as being only pedagogy.

36 Tribhuvan University Faculty of Education. Teacher Preparation Courses. Tribhuvan University has 1-year and 3-year programs leading to a BEd degree.
} 


\section{Figure 5: Qualifications Framework Illustrating Gradual Progression to Higher Knowledge and Skills}

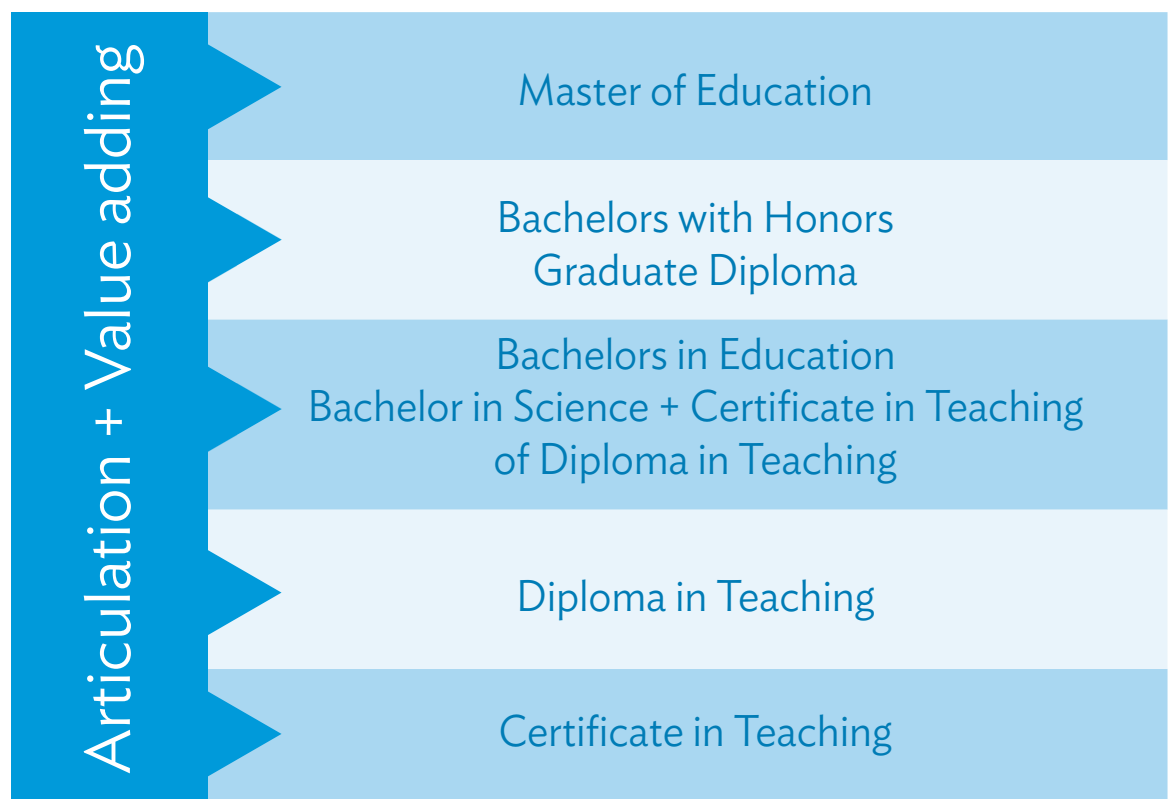

Source: Author's illustration.

education? Under the Bologna convention, it is unethical to expect student teachers to repeat subject content to upgrade their qualifications. The new knowledge and skills provided during the time invested by student teachers needs to be explicitly identified. In Sri Lanka, a teacher can spend 3 years to obtain a Diploma in Education and another 3 years to obtain a BEd (they seem to receive 1-year credit for their diploma toward the 4-year bachelor's degree). Thus, obtaining a BEd could take a total of 6 years. ${ }^{37}$

The secondary teachers have a slightly different challenge. While there are secondary teacher training institutions - such as the TTCs in Bangladesh, the National Institute of Education in Sri Lanka, and the Higher Secondary Education Board affiliate colleges in Nepal-their capacity to provide subject knowledge is limited. ${ }^{38}$ These institutions were initially established to provide the pedagogy part of teacher development. The lack of subject knowledge capacity has seen graduates from these institutions consistently demand subject-based in-service and CPD training. In most Organisation for Economic Co-operation and Development (OECD) countries, the secondary teacher training programs usually have rigorous subject knowledge training, often following a curriculum similar to the general BA and BSc programs. There is also an emerging trend for secondary teacher education programs to have a bachelor's degree plus a postgraduate teaching

\footnotetext{
37 It must be noted that teachers in Sri Lanka are given scholarship with full pay, so a teacher spending 6 years in training is a huge cost to the government. Also, when a teacher is given leave to study, a substitute teacher has to be recruited, which further compounds the costs.

38 Subject knowledge in mathematics, natural and social sciences, and languages.
} 
qualification. ${ }^{39}$ The inability of current secondary science, technology, engineering, and mathematics teachers to effectively teach the content is fueling a debate regarding the suitability of the BEd for secondary teachers.

As noted earlier, the subject area knowledge of graduates coming out of the teacher training institutions has been a contentious issue and a topic of ongoing debate. Since the secondary teacher training institutions are part of government ministries, there is no external quality audit. The downside to graduates from traditional universities is that despite their deeper subject knowledge, they often lack applied pedagogical knowledge. There is need to review both the teacher training institutes and the university programs, and explicitly map their strengths and weaknesses. Recognition of the need to draw on the strengths of these institutions has seen many OECD countries increasingly consider options for a BSc or BA plus a BEd, MEd, or postgraduate diploma in education. In many of the countries participating in this study, the $3+1$ and/or $3+2$ programs are happening by default. Students enroll in general BA and BSc programs, and if they cannot find work after graduation, they take up the teaching pathway. Since these $3+1$ programs are currently happening by default in most countries, it may be easily formalized, particularly for the secondary teachers. By formalizing the process, better monitoring for quality improvement may be achieved.

\section{Content of Programs}

Some contemporary theories such as Vygotskian constructivism, which underpins studentcentered learning, as well as Luria and Leontev's active learning have been introduced through donor-led interventions. Unfortunately, many of these pedagogical practices have not yet been fully institutionalized. Student-centered learning is still viewed as teacherdriven, which undermines the importance of constructivism and resource-based learning, as well as self-directed learning where students use deductive and inductive reasoning, make inferences, and experiment physically and cognitively as they learn. (The next section, "ICT for Education," describes how the resource-based approach can help students develop self-directed learning skills that, in turn, develop a disposition toward lifelong learning.) The instrumental approach used to introduce the new teaching and learning approaches should be supplemented with deeper research and critical inquiry to ensure sustainability and meaningful adoption. Universities and other preservice training providers have not fully adopted this in their programs, as these institutions were not part of the donor-led reform interventions. The institutions that provide preservice training are also the knowledge innovation hubs in each country and need to be directly involved in leading the reforms to ensure long-term sustainability. A review of the programs and the resources currently used by preservice training providers shows they are obsolete and very traditional, covering abstract theories with very little, if any, deconstruction of the theories to link to classroom practices (Gunawardene 2011). This is despite the many years of reform supported by donor partners.

The prescribed course textbooks and library resources, including education research journals used by the training providers in the region, are very outdated (over 50 years old), and are mainly local - there are few national and international journals. This illustrates the

\footnotetext{
39 The Singapore National Institute of Education offers a 4-year BA or BSc in education program that emphasizes both mastery of subject content knowledge plus the pedagogical knowledge. www.nie.edu.sg/files/ote/ Handbooks/General-Information_Jan-Dec_2014.pdf.
} 
risk in working with only the $\mathrm{MOE}$ to improve teacher quality through in-service and $\mathrm{CPD}$ training; and in not working with other stakeholders involved in preservice training. It is understandable to target in-service and CPD programs to have an immediate impact on the millions of teachers already in the system. However, this allows only part of the teacher training systems (in-service and CPD) to benefit. This leaves the MOE to continuously "play catch-up" to make up for poor preservice training. As noted elsewhere in this report, promoting partnerships among institutions providing preservice training and teacher education research is central to the adoption of new teaching and learning knowledge and skills.

Increasingly, even in developed countries such as Australia and the United Kingdom, the role of the teacher is expanding to parenting, policing, health care, and child protection (safe use of ICT, cyberbullying), among others. ${ }^{40}$ Consequently, teacher training programs now include a lot of extras that were once regarded as parent and community responsibilities. This overloads the curriculum and training becomes very thinly spread across a range of content areas, thereby compromising the core function of teachers and schools. ${ }^{41}$ Caution must be exercised when initiatives promoted by international NGOs and donor partners are adopted as a part of the core teacher training programs to ensure synergies and sustainability.

All the countries in the region have disproportionately high in-service and CPD training. In-service training in the participating countries is viewed as the initial training after a person has been hired as a teacher. As noted elsewhere in this report, teachers are first recruited and then sent for training with full salary-hence the term in-service. This model is not sustainable and should be replaced immediately, and all potential candidates should be trained before they are recruited. CPD is the training required to maintain currency of professional knowledge and skills and is often linked to teacher registration and licensure. Both types of training have been supported through government- and donor-funded programs. Wherever the training depends on donor funding, sustainability is questionable. Some countries have adopted compulsory CPD training, but there is a need for a more rigorous demand analysis to match demand with CPD programs. Currently, demand is identified through self-reporting by teachers, but often the demand is more of the same (subject-based training) rather than new innovative aspects such as ICT for education and new assessment methods.

\section{Information and Communication Technology for Education}

ICT has huge potential to support teacher quality improvement. It can help in management, communications, research analysis and reporting, record keeping and file archiving, and delivery of training for capacity development. Delivery modalities such as online learning, blended learning, and hybrid models with a mix of online and face-to-face present enormous opportunities. Current innovations such as massive open online courses (MOOCs) have sparked new enthusiasm for using ICT. As the ICT infrastructure improves and cost becomes affordable, online delivery of teacher training may be considered.

\footnotetext{
40 The current political strategy to appease all interest groups has had the net effect of both expanding the curriculum and exacerbating the perception of the curriculum as being "overburdened" (ACARA 2012, http:// www.acara.edu.au/default.asp).

41 Labaree (1997 and 2012) describes the competing public and private goals of schooling and notes that, 15 years later, the tension between the public and private purposes of schooling remains, whereby schools struggle to both meet social ideals and facilitate individual student achievement via an endless series of education reforms.
} 
ICT may be used for preservice training and for CPD to maintain teachers' currency of knowledge and skills and renew their licenses. However, connectivity limitations should not deter the use of ICT to support teacher development as there are other design applications that can simulate similar learning experiences. There are two target groups for ICT interventions: (i) teachers engaged in training to develop their professional competencies and thus their ability to enhance student learning outcomes, and (ii) the students themselves. Therefore, ICT and e-learning resources can help teachers and students collectively improve student learning outcomes.

There is a common misconception that internet connectivity is necessary to benefit from ICT. Internet connectivity becomes necessary only when there is a need to access materials from the global database of online information that is the web. If the e-learning resources are hosted on a local area network (LAN) or nationally on a wide area network (WAN), the learners can still take full advantage of the strength of ICT for education by the following pedagogical activities:

(i) Visualization for abstract concepts;

(ii) Development of self-directed learning disposition;

(iii) Simulations for dynamic and interactive learning (simulated science, technology, engineering, and mathematic slab activities);

(iv) Student-centered learning and self-learning (can learn at the individual's pace);

(v) Repetition and practices (can be done independent of teachers); and

(vi) High-quality report preparation (word processing, graphs, pictures, video clips, etc.).

The concept of "teacher-led development of e-learning resources" advocated by many of the regional countries is risky as this does not happen in developed countries where teachers have time, access to technology, and examples of internationally recognized good e-learning resources. A few teachers in developing countries may develop e-learning resources, but a whole country's e-learning system cannot be dependent on ad hoc materials. Also, teachers in developing countries have full teaching loads during the working day and may not have access to a computer when they leave school. Thus, expecting them to develop e-resources may be overly ambitious. Current e-learning materials are professionally developed content repositories and libraries indexed to school curricula and grade levels. Encouraging teachers to use ICT in their classroom will require provision of e-learning resources, something that was neglected in previous reform projects and left teachers to find resources from the internet.

Teacher training for integrating ICT in the classroom should be guided by the technological pedagogical content knowledge (TPACK) approach (Figure 6). It is not about expecting teachers to develop e-learning resources. The capacity development should focus on how to use ICT in all subjects to enhance teaching and learning and improve student outcomes. As illustrated in Figure 6, teachers should be trained to appreciate the overlap between traditional pedagogical knowledge and technology knowledge and the overlap between technological and content knowledge. Typically, support has been directed to hardware and connectivity when the real change triggers are appropriate e-learning resources and training teachers to integrate ICT in routine classroom activities. 
Figure 6: Technological Pedagogical Content Knowledge Approach

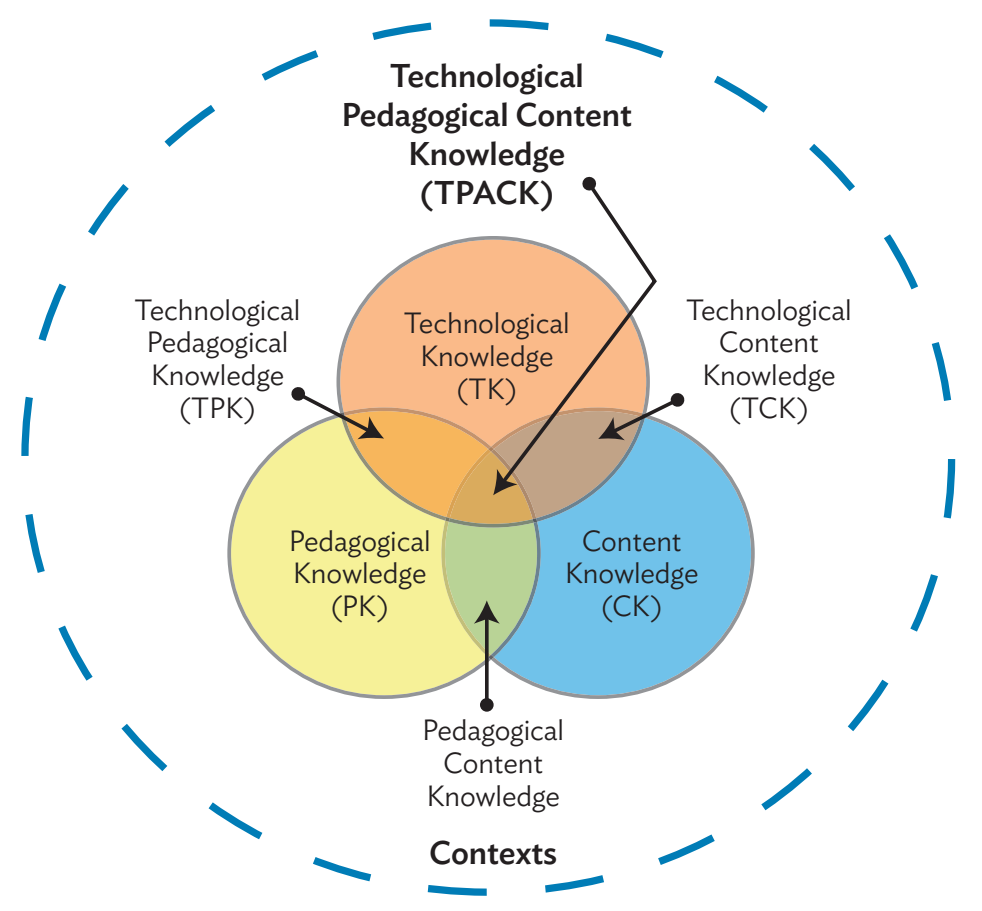

Source: P. Mishra and M. Koehler. 2006. Technological Pedagogical Content Knowledge: A New Framework for Teacher Knowledge. Teachers College Record. 108(6): 1017-1054.

To build the above capacities in teachers, there is potential to strengthen selected resource centers and education training centers as ICT learning hubs. These ICT hubs may attract interest for collaboration from universities and NGOs to enhance knowledge sharing while at the same time increasing utilization of the ICT hubs. This, in turn, ensures sustainability - when more people are using a facility and contributing toward its maintenance, it is more likely to be sustainable. High-quality e-learning resources that are relevant to school curricula can be procured and supplied to all ICT hubs for use by students and teachers.

\section{Delivery of Teacher Training Programs}

Most preservice teacher training programs in the region are currently delivered through traditional models of institution-based, face-to-face instruction. Candidates are required to travel long distances or have to live close to the institutions. Restricting the number of preservice training providers puts pressure (social and economic) on potential candidates to relocate close to the institution. The Open Universities in some countries in the region are now providing distance learning as an alternative. In Nepal, Kathmandu University is working with the Department of Education to use the education training centers as training 
sites to bring preservice training opportunities closer to rural and remote candidates. As noted earlier, the education training centers can be established as ICT hubs for teachers to access resources as well as be the outpost for Kathmandu University. The most effective distance learning models are hybrids, with a mix of self-directed learning and short intensive face-to-face workshops. Currently, most of the distance learning initiatives use print-based material, with varying instructional design quality. Given the limited connectivity, online distance learning is not yet popular.

The delivery of in-service training can be confusing because in some of the regional countries, teachers are first recruited and then sent for training. Even though it is their initial training, it is called in-service training because the teachers are already employed. This is particularly true for primary teachers. However, some countries, such as Bangladesh, are streamlining this and making preservice training a requirement to enter the teaching profession for all primary teachers in the country. Internationally, in-service training and $C P D$ is viewed as value-adding after the initial preservice training has been acquired. In all the countries in the region, in-service and CPD training is currently delivered through faceto-face training by the teacher training institutes, the education training centers, resource centers, teacher centers, and computer training centers.

Most CPD and in-service training is designed and financed by the central ministry but delivered at the local centers using a training of trainers (TOT) model. The instructors are either people recruited from various institutions to participate in a TOT program who then return to their communities and conduct the training, or are a mix of local and central education ministry experts. These courses are short (2-10 days) training workshops and are often didactic, with occasional group work. There are limited resources provided to teachers during these workshops, so when teachers return to their classrooms they do not have any reference material to help with implementing the new teaching approaches. Innovative programs, such as those where teachers selected for CPD are expected to do some pre-reading or collect some classroom data prior to coming to the workshop to discuss, are uncommon.

The other training, such as cluster training, is currently being delivered in most of the countries in the region through the resource centers. ${ }^{42}$ As noted earlier in the report, most of these resource centers are mainly infrastructure investment with limited or no resources. The resource is usually a "resource person" who is a teacher deputized to fill that role. The job description is very ambitious: typically, it requires the person to travel to schools to support teachers and organize cluster group training to share innovations in teaching. This role overlaps with other school inspectors and/or advisors. Funding to support the work of the resource person has also been an ongoing challenge. The concept was first introduced by donor-partner-funded teacher education reform programs with dedicated funding to do this work. The intentions were to (i) develop a culture of knowledge sharing to improve teachers' professional practice, (ii) encourage self-directed learning, and (iii) empower teachers to be the change agents for education reform. Unfortunately, not much new knowledge and skills are being generated during the resource center training programs, given the role overlap with other school inspectors, lack of funding to support resource teachers and resource centers, and lack of access to contemporary literature or input from local universities and TTCs.

$\overline{42}$ Resource centers in Bangladesh and Nepal and teacher centers in Sri Lanka. 


\section{ANALYSIS OF THE TEACHER EDUCATION SYSTEM}

Over the last decade, several teacher education reform initiatives have been implemented in all countries in the region to improve the performance of the education sector. Initially, these reforms were fragmented based on the preferred areas of support by donor partners. However, in recent years, this has changed and a more integrated approach is being adopted through a sector-wide approach and results-based management processes. These new strategies are intended to shift focus away from supply-side reform planning and implementation toward demand-based and/or outcome-based design and implementation. Furthermore, they are also intended to work through the government systems, consequently impacting a system's own processes and procedures to increase sustainability.

\section{A. Demand Forecast}

The demand forecast has been problematic in all countries. The introduction of education management information system (EMIS) and teacher management information system (TMIS) has strengthened the teacher database, but the system still requires further development and capacity to capture more disaggregated data, such as subject specialization of teachers, their qualifications, and frequency of participation in continuing professional development (CPD) programs. Each country in the region has established minimum standards regarding the number of teachers for primary schools based on either the number of classrooms or students in the school. In some cases, the studentteacher ratio (STR) is used to determine teacher demand, which may be useful as general information but does not capture the demand for subject specialization. Similarly, very small rural and remote schools with low STRs are not efficient, but providing access is important; therefore, alternatives such as multi-grade teaching provide an option to ensure access is not compromised and remains in line with the agreed STR. In some of the countries, boarding schools have been successfully utilized to provide basic education. A larger, well-equipped boarding school with sufficient numbers of qualified teachers is better than a small village school with poor facilities, no resources, and untrained teachers. ${ }^{43}$

Reform work under school rationalization programs has tried to consolidate the number and size of schools, particularly primary schools, which seem to have mushroomed everywhere. However, while everyone agrees with the principles underpinning school rationalization, a lack of political will has stalled, or in some cases completely stopped,

43 The government, private sector, and madrasah systems have successfully used boarding schools in many of the countries in the region. 
the initiative. The capacity to supply sufficient numbers of well-qualified teachers in all required geographic areas for very dispersed and small schools will always be a challenge and not efficient and effective. Indonesia adopted alternative models to increase economy of scale and decided that instead of building new lower secondary schools, it was more effective and economical to build additional classrooms in existing primary schools to accommodate the smaller numbers of lower secondary students. ${ }^{44}$ This approach converted primary schools into basic education schools (grades 1-8), which offer potential for sharing of resources, including teachers, and reducing overhead.

In recent years, significant effort has been made to establish robust teacher databases. There has been general improvement, but, in some countries, a lot more work is required to fully establish a TMIS and keep it updated. However, the database and also staff with the specialized knowledge to disaggregate and analyze the data are an essential part of the country's capacity to forecast demand and formulate appropriate policies. For instance, there is currently an oversupply of language and social science teachers, yet the system keeps producing more of the same. A reliable database and good analytical skills can drill down to find out how and why this happens and which regions and/or schools regularly contribute to this problem. In Bangladesh, a subsection of the Bangladesh Bureau of Educational Information and Statistics provides such analytical services. This is an area that is weak and may benefit from further support. In Nepal, the Department of Education generates flash reports that replicate the queries set during the donor-funded reform project, but it is unclear if there is capacity to vary or include new queries. Policy formulation based on evidence requires such data analytic capacity, which currently is limited in the region.

\section{B. Structure of the Education System: Implication for Teacher Demand and Supply}

Primary teachers are generalists, so they can be effectively utilized across subjects and grade levels within the primary education system. The lower secondary, secondary, and higher secondary teachers are specialized and often have single-subject specializations. In most developed countries, basic education teachers (grades 1-8) are generalists but have degree-level qualifications. They have sufficient subject content knowledge to teach a range of different subjects up to grade 8 and thus be full-time professional teachers. It also significantly reduces the total number of teachers required and, at the same time, provides flexibility to ensure teachers' qualifications match with what they teach. The current singlesubject specialization in the region, where small schools with a single stream of classes have a minimum number of classes in a subject area to be taught, results in teachers being asked to teach subjects that they are not trained for, adding to the mismatch of teachers. A similar

\footnotetext{
44 Satu Atap is the Indonesian word for "on roof schools," which has been abbreviated to SATAP by Australian Aid. Ministerial Decree \#32, 2005: Strategic Policy for Equity and Expanding Access. "Satu Atap schools" in Indonesia were formed in remote areas or where the inhabitants are scattered, by adding classrooms for the junior secondary level in a primary school. SATAP is an education program for primary school students. To tackle the problem of teachers, the primary school teachers could teach several relevant subjects in junior secondary school. The competency of primary teachers should be improved so they are capable of teaching at the junior secondary level. Besides that, the existing school facilities such as classrooms and the school building should be fully utilized. The networks between primary schools in the areas (catchment areas) should be considered.
} 
challenge regarding more efficient and effective utilization of teachers also exists in secondary schools. In secondary schools, teachers are specialized in a single subject, when they should have at least two teaching subjects. Again, this allows flexibility to appoint appropriately qualified teachers to teach specific subjects and reduce the mismatch problem.

Bangladesh's 2010 National Education Policy has recommended the adoption of a basic education structure (grades 1-8), which should help streamline the teacher preparation process and provide greater flexibility to match qualifications with the teaching subject. In Sri Lanka, most schools are based on types, rather than primary or lower secondary, so if teachers are appropriately trained, they could easily teach grades 1-8. Sri Lanka has the additional challenge of preparing teachers for schools with three different languages of instruction, which can be an added cost. Some of these structural alignments are happening, albeit very slowly or informally and in a fragmented manner. There needs to be more direct and accelerated actions to increase efficiency and effectiveness of school education in the region.

\section{Institutional Reform and Partnerships for Training Providers}

In the last decade, the region has witnessed expansion of infrastructure to increase capacity to train and supply qualified teachers. During a similar time frame, internationally, the establishment of separate teacher training institutes as parallel higher education systems is no longer considered appropriate, particularly as the teaching profession is no longer considered to be merely a set of skills. It is now recognized that a strong theoretical and research basis is required to innovate, support, and implement modern teacher training. This is to ensure a rich mix of rigorous, research-driven practice to inform teaching practice. In Australia, the Colleges of Advanced Education were merged to form new universities, or merged with existing universities. In Thailand, the Rajapat universities were transformed into comprehensive universities; and in Singapore, the National Institute of Education and the teacher training is now part of Nanyang Technological University. Even in some of the smaller island states like Fiji and Samoa, which are comparable to Maldives, the teacher training institutions have merged with the local university to enhance quality. What is needed is a system for accrediting institutions, private and public, which can deliver teacher education training and capacity development. As noted earlier, this may be integrated with the national teacher development framework.

Given the lack of government funding for maintaining the infrastructure of the existing teacher training institutions, building more facilities will only worsen this situation.

An alternative approach to increasing access and at the same time ensuring minimum quality may be to leverage existing facilities by formalizing partnerships and twinning arrangements between teacher training institutes and universities. Such partnerships can strengthen the quality of the programs and help the teacher training institutions comply with the accreditation requirement, thus lifting the base level of the teacher training institutions. This may not be possible in every situation, but it will significantly reduce the need for more infrastructure investment and nonaccredited institutions to increase access to teacher training. A partnership seeks to draw on the strengths of each party; it should not 
be seen as a "takeover" or outsourcing for a service. Currently, there is a lack of appreciation of operational mechanisms underpinning genuine partnerships by the stakeholders in the region.

In Nepal, over 1,000 affiliate colleges are linked to Tribhuvan University. While these may appear to be "partnerships," they are not, and that term should be avoided-these arrangements just involve selling the brand name for a fee. A partnership requires joint investment and sharing in risks and benefits-a significantly different arrangement. In Bangladesh, ADB's Second Teaching Quality Improvement in Secondary Education Project (TQI-II) has initiated partnerships between teacher training colleges (TTCs) and local universities to strengthen the subject content knowledge of secondary teachers, although there is still a lot of reluctance to accept the proposed intervention. This arrangement is not just for government TTCs but also for private TTCs and universities that satisfy the minimum quality requirements.

All good universities in the region (private and public) have the necessary human resources, library facilities, and language and science laboratories to provide high-quality teaching and learning in all the secondary subjects. In comparison, the secondary TTCs have limited capacity to provide the necessary subject content training. This limitation is even more severe for the science, technology, engineering, and mathematics subjects. Some universities have an education faculty that undertakes education research and could work with the teacher training institutes to strengthen the pedagogical practice. Consequently, twinning arrangements where students obtain a basic degree (BSc or BA) from a comprehensive university and then take a BEd or postgraduate diploma in education from a teacher training institute to become a teacher are now happening by default in many countries in the region. If these can be formalized, they could be better monitored and supported for quality.

Similarly, partnerships with private sector providers should also be considered to increase access to teacher training and provide some competition and benchmarking. The BRAC teacher training program and the private TTC in Bangladesh, Ratho Bangala; the Teach for Nepal programs coordinated by Kathmandu University in Nepal; and the Gateway College teacher training in Sri Lanka all provide alternative models of teacher training. Unfortunately, to date, there has been very little serious engagement between the private and public sector teacher training providers.

There is a concern that the governance of primary and secondary teacher training institutes is aligned with the education ministry, and therefore is separated from the national higher education system, which falls under the purview of a separate ministry (often the ministry of higher education or equivalent). There is an urgent need to explore options to bring all higher education institutions (including teacher training institutes) under a common governance model for better quality monitoring and management and sharing of resources through partnership arrangements.

In Nepal, the government is currently developing legislation to support the work of the University Grants Commission. It is intended for this work to bring all higher education institutions, including teacher training, under one governance model. In Sri Lanka, the higher education sector is undergoing major reform, and thus provides an opportune 
moment to consider bringing the National Institute of Education and the National Colleges of Education together under one higher education system. The situation in Bangladesh is a bit more complex: the primary teacher training institutions are under the Directorate of Primary Education, and the National Academy for Primary Education issues the certificates. The secondary teacher training institutes are under the National University, which is not a university but a board that issues certificates. Both these arrangements are outside the national university system. Thus, there is need for significant restructuring and alignment of higher education institutions involved in teacher training to strengthen the quality of teacher preparation and supply.

Implementing national teacher standards and minimum quality standards across fragmented and different governance jurisdictions can be a challenge. Supporting parallel systems is not only expensive but also discourages partnership and knowledge sharing that, in turn, undermines quality improvement. Investing more in infrastructure to expand teacher training capacity may not be the best way forward.

\section{Utilization of Existing Teacher Training Facilities}

Related to the above discussion is utilization of the existing teacher training and support infrastructure. Table 3 provides a summary of teacher training facilities in the three large countries in the region.

\section{Table 3: Teacher Training Infrastructure in Each Country}

\begin{tabular}{|c|c|c|}
\hline $\begin{array}{r}\text { Ban } \\
\text { (teache } \\
=6\end{array}$ & $\begin{array}{r}\mathrm{Ne} \\
\text { (teacher } \\
=275\end{array}$ & $\begin{array}{r}\text { Sri } \\
\text { (teacher } \\
=2\end{array}$ \\
\hline $\begin{array}{l}\text { Government teacher training } \\
\text { colleges (14) } \\
\text { - Private teacher training colleges } \\
\text { (104) } \\
\text { - Primary teacher institutes (54 } \\
\text { plus more planned) } \\
\text { - Upazila (subdistrict) resource } \\
\text { centers (174) } \\
\text { - Higher secondary teacher } \\
\text { training institutes (5) } \\
\text { Bangladesh Madrasah Teachers' } \\
\text { Training Institute ( } 1 \text { ) } \\
\text { - Universities (data not available) }\end{array}$ & $\begin{array}{l}\text { Education training } \\
\text { centers-A (9) } \\
\text { - Education training } \\
\text { centers-B (20) } \\
\text { - Education training } \\
\text { centers-C (5) } \\
\text { - Resource centers (1,400) } \\
\text { - Higher Secondary } \\
\text { Education Board (data not } \\
\text { available) } \\
\text { Universities (data not } \\
\text { available) }\end{array}$ & $\begin{array}{l}\text { - Teacher training centers (9) } \\
\text { - Teacher centers (104) } \\
\text { - Computer resource centers } \\
\text { (73) } \\
\text { - Provincial information and } \\
\text { communication technology } \\
\text { centers (9) } \\
\text { - National Colleges of } \\
\text { Education (18) } \\
\text { - National Institute of } \\
\text { Education (1) } \\
\text { Universities (data not } \\
\text { available) }\end{array}$ \\
\hline
\end{tabular}

Note: All-inclusive and comprehensive data are not available.

Source: Compiled by the author.

The facilities at these institutions range from two classrooms, an office, a storage room, and toilets, to several classrooms, a number of faculty offices, seminar rooms, boarding for boys and girls, a kitchen and dining room, and recreational facilities. Many of these facilities are underutilized while the government is paying huge maintenance costs. Perhaps the 
most underutilized of all these facilities are the resource centers, most of which have no resources. In Nepal, Kathmandu University is currently negotiating with the central Department of Education to use the education training centers as remote sites to deliver their distance learning. The income generated can be used to maintain the facilities and to support the distance education program. Kathmandu University may also establish a library for its distance learners, which can be opened to other teachers as well. There is an urgent need to undertake an infrastructure utilization study and explore other uses of the facilities to generate some revenue to cover maintenance costs (the government has very little provision for maintenance of its infrastructure) without compromising access to teachers for their continuing professional development (CPD) and in-service training. If the Kathmandu University partnership is successful, then other similar arrangements should be considered. Similar innovative ways to utilize these facilities in Bangladesh and Sri Lanka can significantly help improve teacher quality in respective countries and reduce wastage.

\section{E. Teacher Quality Improvement}

Over the last decade, the region has had multiple interventions to improve the quality of teachers. Results have been mixed, and it appears these processes are getting saturated, requiring new and more innovative interventions to further progress the reform. The interventions were supported through huge in-service and CPD training programs that lacked structural and systemic reforms. Continuing down this path may not be sustainable once external support ends. Hence, a more systemic approach is required. Teacher quality starts with having national teacher standards so that all stakeholders recognize what constitutes teacher quality, and all investments can explicitly state how and what value they are adding. Furthermore, the report cautions that the standard framework should not be limited to just pedagogy competencies; it should also take into consideration subject content knowledge. To ensure compliance with national teacher standards, each country should develop a quality assurance system supported by legislation. This is particularly important given the emergence of private sector training providers, which often are driven by profit rather than quality. By having a legal basis, noncompliance may be challenged in court if the bureaucracy fails to act. It is critical that there be strong alignment between national teacher standards, accreditation of institutions providing training, preservice programs, CPD programs, and teacher performance monitoring.

One of the simplest ways to improve quality is to lift the entry level, particularly in larger countries in the region that have an oversupply of graduates looking for jobs. As noted earlier in this report, setting entry requirements very low discourages graduates from applying. In rural areas, where attracting graduate recruits is difficult, a case-based approach may be adopted. The training programs advocate contemporary teaching and learning approaches to be applied in schools (student-centered, activity-based, peerbased, and self-directed learning) for school children, but the irony is that these approaches are not equally used in teacher training programs - teachers are taught to apply them to students, but do not experience them in their own training. Adult learning approaches (such as self-directed, problem-based, and lifelong learning) are rarely seen in current teacher training programs. Also, to date, most effort toward teacher quality improvement has been directed toward teachers in the system; consequently, not much direct support has been provided for improving the delivery of preservice teacher training. 
Despite all the training on new teaching and learning methods, the main resource for a teacher is still the textbook and, in some cases, teacher guides. While there is an expectation that teachers will undertake self-development, and thus develop their own teaching and learning resources, access to the latest literature and resources to assist teachers in upgrading their knowledge and skills is very limited in the region. As noted previously, even the university libraries have limited contemporary teacher education material. The teacher colleges are in a worse state than the universities when it comes to accessing teaching and learning resources. Even in the information and knowledge age, access to good teaching and learning resources in the region unfortunately remains very limited. This pattern is also reflected in the other institutions (education training centers, teachers' colleges, resource centers, etc.), which are supposed to assist teachers in improving their knowledge, skills, and practice. Most current training activities are very didactic and oral with very little, if any, reading or reference material developed and/or supplied to teachers. When teachers return to their classrooms, they have virtually no reference material, and it is not long before they forget what they learned in the training. Hence, manuals, reference materials, and teaching and learning material, in the form of traditional or electronic libraries, can significantly help improve teacher quality.

Finally, recent teacher quality improvement experiments such as "Teach for Nepal" and "Teach for Australia" are innovative projects that attracted top science and engineering graduates to spend some time teaching in secondary schools. ${ }^{45}$ These students, being high achievers, applied the same attitude to their teaching assignments. Interestingly, many of these students have extended their internships and continued teaching. This model is very different from traditional teacher training, and the evaluation shows that teacher performance improved as measured by student achievement. The downside is that it is more expensive (resource-intensive) than the traditional teacher training models.

\section{Teacher Performance Monitoring}

Despite the decentralization of primary and secondary education, most countries still have teacher performance reviews conducted by provincial or district inspectors. In a decentralized model, the most immediate organizational unit that has the capacity to regularly monitor teacher performance is the school. The head teacher is the best person to do this task. Some countries in the region have adopted school-based improvement, but the delegation of teacher performance monitoring has not been fully devolved to the school. ${ }^{46}$ If head teachers are to review teacher performance, then it should be part of their formal job description and they should be given adequate time to carry out the role. In many countries in the region, the head teacher role is an "add-on" job, over and above their teaching workload. For school-based teacher performance to be successfully implemented, the role of the head teacher needs to be revised and sufficient training in teacher performance monitoring should be provided.

Considering the difficulty associated with regular school visits in many of these countries (mountainous terrain, poor roads or wide areas of ocean, limited travel budget), visiting

\footnotetext{
45 See Teach for Nepal website (www.teachfornepal.org).

46 These are school-level improvement plans in Bangladesh, and primary education and school-based improvement in Sri Lanka and Nepal. In the school-level improvement plan program, a trial on delegating teacher performance monitoring to head teachers is showing mixed success. It is still at an early stage and continued support is needed for it to be institutionalized to determine the full impact.
} 
schools periodically to monitor teachers is not easy or cheap. Traveling to every school and observing every teacher is a huge task that will require an army of school inspectors. In some cases, one inspector has to visit over 100 schools annually and observe all the teachers in those schools. The salaries of the school inspectors, plus their travel expenses, have been a major constraint to effective teacher monitoring. In some countries in the region, the school inspector system is not working at all. Hence, the school-based approach makes more sense: it is economical and meaningful, as the head teachers are motivated to make their teachers perform their best to show good student learning outcomes. If there are areas of deficiency, then the head teacher can request appropriate CPD programs. ${ }^{47}$

Currently, there is lack of clarity in roles. The school inspectors monitor teacher performance, provide training and instructional advice, act as training of trainers (TOT) trainers to deliver CPD, and also do general school inspections. In some countries, the resource teacher or district-level trainers also act as inspectors because they determine CPD demand and provide the training. Then there is the head teacher who also monitors teacher performance. Despite teacher performance monitoring happening at three levels, the real performance limitations are still not being captured and, thus, the same "demandbased" in-service training is repeated every year with little impact on teacher quality.

\section{Information and Communication Technology: A Tool to Support Teacher Development}

E-learning is thought to be one of the fastest-growing industries and has been frequently heralded as a transforming influence on education systems globally (Pillay and Kappus 2015). Unfortunately, connectivity, particularly internet connectivity, is often viewed as being synonymous with e-learning. E-learning (also known as digital learning) can be delivered through local area network (LAN), wide area network (WAN), or an internetbased system. LAN and WAN may provide connectivity without having to channel traffic through the internet, consequently making it more cost-effective and increasing the access speed significantly. A 2012 International Telecommunication Union report ${ }^{48}$ notes that internet penetration in Bangladesh was 5\%; Bhutan, 21\%; Maldives, 21\%; Nepal, 9\%; and Sri Lanka, $15 \%$. In most cases, most of this population was in the larger metropolitan areas. This should not deter the use of e-learning, which requires e-learning resources, a database to store all e-resources, and devices to access and display the e-learning resources. Thus, when designing an e-learning system, certain key questions need to be posed:

(i) What is the purpose of internet connectivity? Why do you need this?

(ii) Where and how will the e-learning materials be hosted?

(iii) What and how will information be used by students and teachers? Does it require synchronous or asynchronous access?

(iv) How many people will access it simultaneously?

Answers to the key questions will determine the type of connectivity and synchronous access necessary. For instance, if the learning material is stored on a LAN server at the school, education training center, teacher center, or resource center, then internet access may not be necessary and it can be easily accessed at high speeds locally. Speed

\footnotetext{
47 In the State of Victoria in Australia, teacher recruitment, performance monitoring, recommending CPD training, termination, etc., are all functions of school principals.

${ }^{48}$ See ITU webpage (http://www.itu.int/en/ITU-D/Statistics/Pages/stat/default.aspx).
} 
is particularly important when working with resource-rich simulations, which are typical of most good e-learning materials. Slow or uncertain connectivity causes frustration and demotivates the teachers from using the e-learning resources. Therefore, the speed of access should be a key consideration when designing an e-learning system. The limited and poor quality of internet services should not deprive teachers in these countries from benefiting from e-learning. If there is electricity, a LAN with e-learning materials indexed to a school curriculum can be provided to teachers and students. Such materials will help teachers to update their subject content knowledge and help students to use self-directed learning. As noted in the report, some of the currently underutilized facilities can easily be converted to information and communication technology (ICT) hubs as learning centers with sufficient ICT equipment and e-learning resources supplied. These places can be opened to teachers and students. When the quality, availability, and affordability of internet service is improved, then LAN or WAN can easily be connected to the internet.

Countries in the region have developed teacher portals and portals to host learning materials. ${ }^{49}$ These have had mixed success because of two key factors: (i) the very slow connectivity in rural and remote areas generally, and particularly when accessing resourcerich materials; and (ii) the resources on these portals are often not carefully planned, or are of a very high quality. These collections of materials are not directly relevant to school curriculum and teaching and learning, such as an e-library (Figure 7). The importance of good quality, high relevance, and easy access of e-learning resources cannot be overemphasized. It will help both the teacher and the student to benefit from self-directed and self-paced learning and support the teacher's role as a facilitator who closely monitors student performance and assists slow learners. Good use of ICT and e-learning resources can help both teachers and students in achieving better learning outcomes.

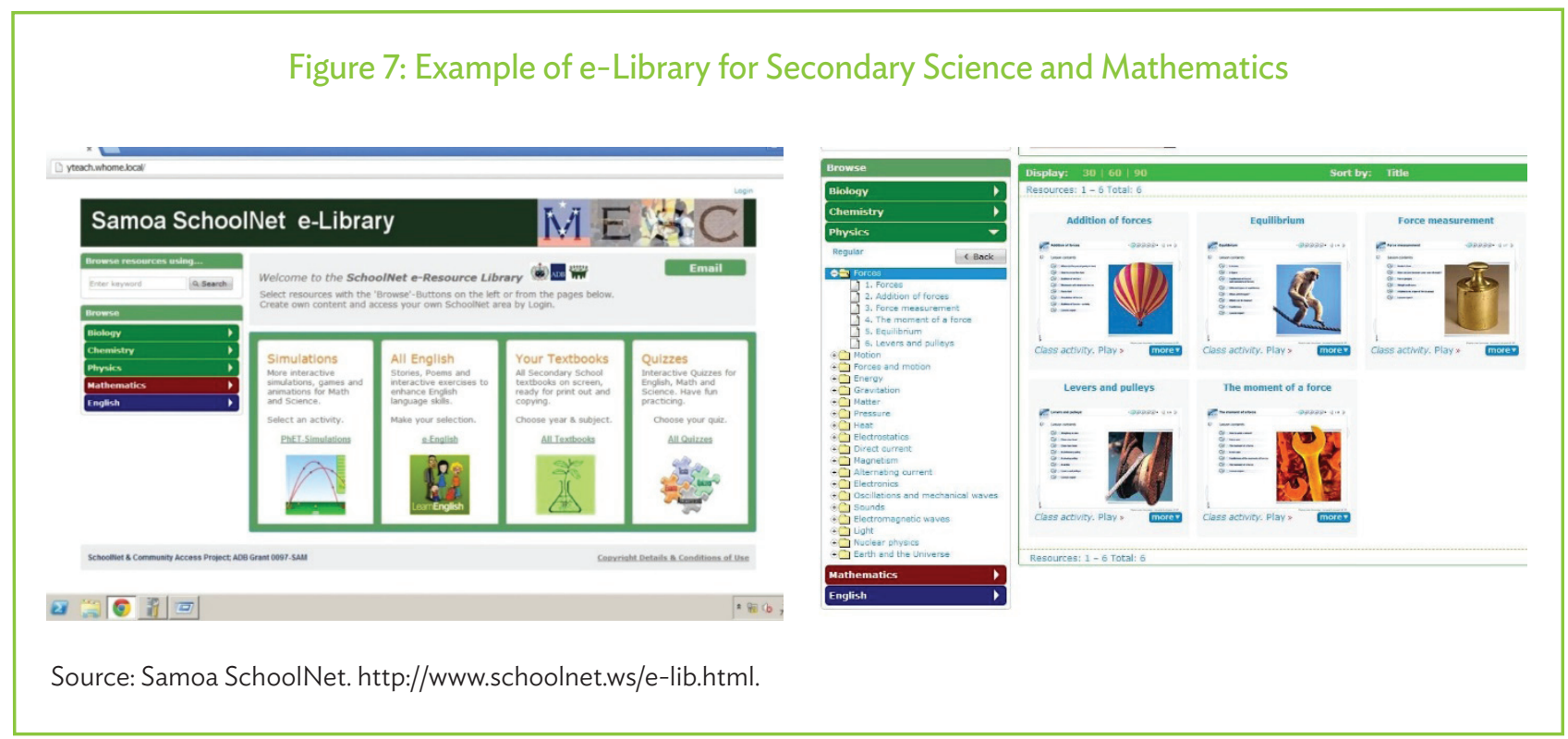

\footnotetext{
${ }^{49}$ See, e.g., the following websites: www.teachers.gov.bd (in Bengali), National Curriculum and Textbook Board (http://www.ebook.gov.bd, in Bengali), Leigh (n.d.); National e-learning Portal for the General Education (http:// www.e-thaksalawa.moe.gov.lk/web/index.php?lang=en).
} 
Most universities, including open universities, in the region have not yet fully embraced online learning. As a result, most distance learning for teachers currently is a mix of printbased and face-to-face teaching and learning. Despite some donor-led ICT interventions, this is unlikely to change soon because of the connectivity issue noted earlier. However, converting the education training centers in Nepal, the teacher centers in Sri Lanka, and selected teacher resource centers in Bangladesh into e-learning centers (ICT hubs); along with supplying appropriate equipment, ICT-qualified teachers, e-learning resources, education research tools, and usual library materials have the potential to change the teacher training paradigm. It will be resource-based learning, driven by selfdirected learning as opposed to the instructor-led teaching that is currently evidenced in most teacher training programs in the region. Partnerships between training providers, universities, international and domestic nongovernment organizations (NGOs), donor partners, and the Ministry of Education (MOE) can jointly make this successful. Partners who use the services adopt a user-pays approach to recover costs, particularly maintenance and regular updating of the e-resources. When the connectivity improves in each country, the e-learning centers can be easily connected to the internet network. 


\section{WAY FORWARD: TEACHER PROFESSIONAL DEVELOPMENT PRIORITIES}

T his section provides a summary of the key priority issues synthesized from the national reports that will help improve the teacher development system's capacity to effectively address issues related to teacher quality, demand and supply, and teacher performance. Given that there are finite resources for education in all countries, any increase in one area will have a corresponding decrease in some other, unless the overall education budget is increased. Hence, there is a need to adopt a systems approach to strategically and gradually develop high-quality teachers and optimize their performance.

\section{A. Systems Approach to Teacher Quality Improvement}

\section{Conceptual and Organizational Issues}

(i) Most participating countries have initiated some form of national teacher standards framework (NTSF) that outlines the key teacher competencies and performance indicators, categorized as knowledge, skills, and applications. These are at various stages of development and all require further development and support. The NTSF needs to include a balance of both subject content and pedagogical knowledge and skills, which is missing in most current NTSFs. The importance of having separate standards for primary and secondary education, and for each subject, is also not yet fully appreciated under the current initiatives. Finally, some regional or international benchmarking and the eventual design underpinned by research evidence can add credibility to the standards framework.

(ii) Organizational and institutional issues such as autonomy, legal basis, interdependence of different organizational structures and functions, and the need for periodic reviews of the NTSF are not yet fully appreciated and thus impact the implementation. The notions of conflict of interest, avoiding duplications, and adopting a transparent and legitimate system are all critical to ensure stakeholders' acceptance, respect, and willingness to comply.

(iii) Furthermore, implementing the NTSF will require dedicated professional staff who understand current research and contemporary practices in teacher education systems so they can continuously review and improve the standards framework. The current situation varies in each country, ranging from people appointed from the general public service cadre, to personnel temporarily deputized either as full-time or part-time staff, to newly appointed peoplesome with good technical knowledge and others who are political appointments. 
The first two options create high staff turnover and thus perpetuate the loss of institutional and technological knowledge and practices despite all the capacitybuilding investments.

(iv) Integrity of a national standards framework and stakeholder ownership depend on the level of transparency and ongoing communication entertained by the NTSF authority. Critical processes such as recording board meetings and keeping a document trail of discussions and decisions made can help increase transparency.

\section{Structural and Functional Issues}

(i) National teacher registration and licensing systems should apply to all teachers in the country. The different specifics for primary and secondary teachers should be clearly described. The teacher registration process should validate if potential candidates have the necessary competencies identified in the NTSF. This may be achieved by conducting a formal test, examining professional portfolios, conducting interviews, or any combination of the above.

(ii) To ensure currency of teacher competency, renewal of registration or license may be used as mechanisms for teachers to demonstrate that they have been investing in self-development. The self-development may be achieved by teachers participating in a minimum number of approved continuing professional development (CPD) programs, submitting a professional portfolio, passing a formal test, or any combination of the above. The CPD course should be linked to NTSF and explicitly state what aspect is being targeted in the training programs.

(iii) Training providers, including universities, have to demonstrate how their teacher training programs have embedded the NTSF competencies, as well as how knowledge, skills, and applications are progressively enhanced as a teacher completes higher-level programs. Providers should clearly state the articulation process and possible course credits between levels of programs.

(iv) Teacher performance monitoring should be done against the NTSF since these are designed to help teachers improve their classroom practices and help improve student learning outcomes. As a system, the alignment between the initial preservice training, the CPD programs, and teacher performance monitoring is critical as it reinforces the importance and centrality of the NTSF. Teacher performance monitoring is most effective when done at the school level, so capacity development of head teachers is necessary.

\section{Quality of Programs and Service Providers within a National System} In all participating countries, there is no shortage of postsecondary institutions offering teacher training programs. Many of these were conceptualized a long time ago, and thus their programs do not match the competencies required of 21st century teachers. Furthermore, as noted in the national reports (Appendixes 1-3), almost all reform initiatives focused on in-service training to effect an immediate change to the teaching and learning processes in the classrooms. This has provided less-than-satisfactory results; hence, the recommendation now is for systemic reform.

\section{B. Institutional Issues}

(i) Registration of accredited teacher training providers is a critical step toward quality improvement. This information should be made public so potential 
candidates are aware of a provider's status when choosing a program. A webbased system may be used to display all nationally accredited providers of teacher education, and should be periodically updated. Accreditation should be at two levels: minimum physical facilities and compliance with the NTSF.

(ii) To avoid constantly playing catch-up, there is an urgent need to review the preservice training for its program structure, alignment with the NTSF, and delivery modalities. The review process should include comprehensive research of higher education conventions and practices such as the Bologna Declaration on higher education to identify a workable framework for individual countries.

(iii) As noted in all country reports, there is a huge supply of unemployed graduates in the market. The challenge is how to recruit them into the teaching profession without increasing the salary budget. There is a need to raise the entry requirements for the teaching service to elevate the profession's status and make it attractive to graduates who can bring a higher level of professional competence to the teaching workforce.

(iv) Increased teaching and learning resources and facilities are necessary, such as traditional and electronic libraries, to encourage self-directed and lifelong learning. Options for procuring information and communication technology (ICT)-based resources such as an open access journal, open education resources, and other e-learning resources to stimulate self-directed learning and selfdevelopment among teachers.

\section{Training Programs}

(i) To ensure all preservice training programs meet the NTSF standards, benchmark programs against NTSF to validate compliance for agreed norms for subject content knowledge and pedagogical knowledge. Modernize programs by including contemporary practices such as problem-based, student-centered, self-directed and lifelong learning, and activity- and project-based learning.

(ii) Increase flexibility for teacher deployment by consolidating teacher specialization as basic and secondary education teachers. Make it mandatory that all teacher training programs ensure capacity to teach at least two subject areas (secondary teachers) and multiple subjects (primary teachers).

(iii) Clearly articulate in programs credit accumulation to progress to higher qualifications and equivalence across different training providers, including CPD.

\section{Optimizing Infrastructure Investments}

To increase the supply of good teachers, most previous investments in teacher development placed significant emphasis on building teacher training institutes, teacher resource centers, professional development centers, and so on. Traditionally, teacher training has been considered outside the comprehensive higher education system, which led to the development and expansion of a parallel higher education system. This is no longer sustainable in terms of both the quality of teachers graduating from the two systems, plus the cost implication of supporting the parallel systems.

(i) There are many potential providers of teacher training in each country. To increase efficiency, priority should be placed on merging and leveraging the resources of the existing teacher training providers, not building more institutions. It will be good to access the strength of teacher training institutes 
for pedagogy, and the universities for subject content and explore collaboration options. Universities (private and public) are significant stakeholders in teacher development and are perceived to be of higher quality for subject content knowledge in the region. Public-private partnerships and twinning arrangements should be considered to leverage the strengths of different institutions and improve the quality of graduate outputs.

(ii) The available teacher development infrastructure, built by the various projects, is currently seriously underutilized. A utilization and optimization study of existing facilities can help maximize return on investment and inform any infrastructure investments noted for teacher development in the development assistance pipeline.

(iii) Many of the various outreach facilities, such as teacher resource centers, are not being used and have few, if any, teaching and learning resources. The regional governments cannot provide the regular funds for operation and maintenance. There is an urgent need to minimize infrastructure expansion and provide teaching and learning facilities, including ICT facilities and e-learning resources. The other option is to consider leasing facilities to other teacher training providers to supplement operational costs.

\section{Information and Communication Technology Facilities and E-Learning Resources}

The potential for ICT to contribute to education in general and to teacher education in particular has not been fully appreciated in all the countries in the region, despite the international recognition and adoption of the same. Most ICT investments to date have concentrated on strengthening management systems, and some fragmented investment is providing ICT equipment to teacher training colleges.

(i) To maximize the benefits of ICT investments, adopt a systematic approach to integrate ICT into all aspects of teacher development, including the NTSF, the initial preservice program, and teacher performance monitoring. Adopting an integrated national policy will minimize redundancies, incompatibility, obsolescence, etc., and thus increase efficiency.

(ii) Upgrade teacher training institutions' libraries by developing e-library facilitiesprocure open education journals and other open educational resources and/or selectively seek affiliation with commercial resource providers. Providing access to good quality resources empowers teachers and promotes self-development. E-learning resources can help teachers improve their subject content knowledge as well as their pedagogical practices. The e-learning resources for subject content knowledge can also be used by students, so the investment can have multiple benefits. Access to good learning resources is a major impediment to education in the region.

(iii) To increase access to e-learning, identify selected teacher resource centers and learning centers and establish e-learning centers. Connectivity is not a prerequisite for e-learning. Negotiate with training providers to use the selected outreach facilities to jointly establish libraries with e-learning resources for teachers and students.

(iv) Develop human resource capacity to provide continued support to ICT interventions, preferably through established positions within the government 
departments or through service contracts. Having qualified staff is critical for ensuring that both national and rural ICT centers are regularly upgraded and maintained. Capacity is also necessary to develop and curate a national teacher professional development repository.

\section{Managing Teacher Demand and Supply}

(i) As noted in the national reports, the countries' initial push to increase access considered ways to rapidly train enough teachers to meet the demand. However, over the years, teacher demand has become more complex: consideration of rural and urban demand, gender equity, subject specialization and mismatch, and so on require more disaggregated analysis. Furthermore, the management of teacher demand and supply is now being expanded to include quality measures-hence the push for developing and establishing the NTSF. Managing supply requires enhancing the capacity of education management information systems (EMIS) to collect data and undertaking more complex and disaggregated analytics to forecast medium-term demand. There is a need for strategic analytics, rather than simply the student-teacher ratio, as the basis for demand forecast. For instance, the ability to track the number of trainees in the system (private and public) and their specializations, and match those numbers with medium-term demand, can help to manage expectations of graduates seeking teaching jobs.

(ii) Recruitment policies should be changed to hire only candidates who have already received training - as is done in every other profession. This will eliminate the expansive practice of recruiting unqualified individuals and sending them for training with full pay-a very inefficient system. Policies to deal with exceptions (such as remote places where deployment of trained teachers may be a challenge) should be available only on a case-by-case basis-not a national policy.

(iii) Related to the above point is managing the high attrition from the teaching workforce, which ranges between $5 \%$ and $10 \%$. With strategic replacement with high-quality teachers, within 5 years, the system will have 25\%-50\% of teachers who are of high quality, and this core group can create enough impact to change the practice from within the system.

(iv) All regional countries have an abundant supply of self-funded graduates looking for jobs, a valuable human resource that is currently not being utilized and should be tapped. Intensive pedagogical training can transform them into good teachers. The efficiency gained by doing this can be used to incentivize teacher performance. Recruiting teachers from graduates who have funded themselves saves government money. The governments just provide short-term pedagogical training and the savings can be used to provide incentives for teacher performance through awards that may include financial rewards. 



\section{REFERENCES}

Asian Development Bank (ADB). 2014. Poverty in Asia: A Deeper Look. In Key Indicators for Asia and the Pacific 2014. Manila. www.adb.org/publications/key-indicators-asiaand-pacific-2014.

Australian Curriculum, Assessment and Reporting Authority (ACARA). 2013. www.acara. edu.au/home_page.html.

Australian Institute for Teaching and School Leadership. 2011. National Professional Standards for Teachers Feb 2011. www.aitsl.edu.au/verve/_resources/AITSL_ National_Professional_Standards_for_Teachers.pdf.

Australian Qualifications Framework Council. 2013. Australian Qualifications Framework. www.aqf.edu.au/wp-content/uploads/2013/05/AQF-2nd-Edition-January-2013.pdf.

Benelux Bologna Secretariat. 2007-2010. Bologna Process. www.ond.vlaanderen.be/ hogeronderwijs/bologna/about.

Central Bank of Sri Lanka. 2012. Economic and Social Statistics of Sri Lanka 2012. www.cbsl. gov.lk/pics_n_docs/10_pub/_docs/statistics/other/econ_\&_ss_2012.pdf.

General Teaching Council for Scotland. 2012. The Standards for Registration: Mandatory Requirements for Registration with the General Teaching Council for Scotland. www. gtcs.org.uk/web/Files/the-standards/standards-for-registration-1212.pdf.

Government of Malaysia, Ministry of Education. http://web.moe.gov.my/sgm/

Government of Nepal, Central Bureau of Statistics (CBS). 2011. Nepal Living Standards Survey 2010/11. http://cbs.gov.np/wp-content/uploads/2012/02/Statistical_Report_ Vol2.pdf.

Government of Nepal, Department of Education (DOE). 2012a. School Level Educational Statistics of Nepal: Consolidated Report 2011 (2068BS). www.ncf.org.np/upload/ files/1007_en_Consolidated\%20Report\%202068\%20(\%202011)_1346397795.pdf.

- - - 2012b. Status Report-2011: School Sector Reform Program; Second Higher Education Project; Community School Capacity Development Program; Education for All ShishuVikasKaryakram. Sanothimi. www.doe.gov.np/SoftAdmin/content/Status_ Report_2011.pdf.

Government of Nepal, Ministry of Finance (MOF). 2012a. Summary of Expenditure Allocation for Fiscal Year 2011/2012. Kathmandu.

- - - 2012b. Economic Survey Fiscal Year 2011/12. Kathmandu.

Government of Nepal, Ministry of Law and Justice. 2001. Education Act (7th Amendment). Kathmandu.

2007. Interim Constitution of Nepal, 2063. http://himalaya.socanth.cam.ac.uk/ collections/rarebooks/downloads/Nepal_Interim_Constitution_2007_first_to_ sixth_amendements.pdf. 
R. Gunawardene. 2011. A Study of the Effectiveness of Short Term In-Service Teacher Training in the Teaching and Learning Process. Colombo: Sri Lanka National Education Commission.

Government of Sri Lanka, Ministry of Education. 2013. The National e-learning Portal for General Education. www.e-thaksalawa.moe.gov.lk/web/index.php?lang=en

J. Hattie. 2008. Visible Learning: A Synthesis of over 800 Meta-Analyses Relating to Achievement. New York: Routledge.

Internet World Stats. Usage and Population Statistics 2001-2014: Internet Users in Asia 2012 Q2. www.internetworldstats.com/stats3.htm.

C. Leigh. n.d. SchoolNetMoodle>Electronics. http://moodle.schoolnet.lk/course/view. php?id=31.

D. Labaree. 2007. Public and Private Goods: The American Struggle over Educational Goals, American Educational Research Journal. 34(1): 39-81.

- - - 2012. School Syndrome: Understanding the USA's Magical Belief that Schooling can Somehow Improve Society, Promote Access, and Preserve Advantage. Journal of Curriculum Studies. 44(2): 143-163.

P. Mishra and M. Koehler. 2006. Technological Pedagogical Content Knowledge: A New Framework for Teacher Knowledge. Teachers College Record. 108(6): 1017-1054.

Nanyang Technological University, National Institute of Education. 2013. Handbook. www. nie.edu.sg/files/ote/Handbooks/General-Information_Jan-Dec_2014.pdf.

National Council for Teacher Education, India. 2009. National Curriculum Framework for Teacher Education 2009. New Delhi. www.teindia.nic.in/files/national_curriculu-forteacher-education-2009.pdf.

National Council for Teacher Education, India. www.ncte-india.org.

H. Pillay and W. Kappus. (2015) E-learning Intervention for Stem Education: Developing Country Case Study. In L. Uden, D. Liberona, and T. Welzer (eds.) Learning Technology for Education in Cloud. LTEC 2015. Communications in Computer and Information Science, Vol. 533.

K. Shrestha. 2008. Teacher Development at Secondary Education in Nepal. Journal of Education and Research. 1(5): 41-50. www.mcser.org/images/stories/JESR-SpecialIssues/JESR-December2011/leela-pradhan.pdf.

J. Smeed. 2013. Over Time Assessment Data Analysis Tracking a School's On-going Performance. Australian Educational Leader. 35(1): 35-37.

Teach for Australia. www.teachforaustralia.org.

Teach for Nepal. www.teachfornepal.org.

Tribhuvan University Faculty of Education. 2014. Teacher Preparation Courses. http://tufoe. edu.np/teacher-preparation-cources.

United Kingdom Department of Education. www.education.gov.uk.

University Grants Commission (UGC). 2012. Education Management Information System: Report on Higher Education 2010/11 Nepal. Kathmandu.

E. Valenzuela. 2010. Teaching Competency Standards in South East Asian Countries: Eleven-Country Audit: Southeast Asian Ministers of Education (SEAMEO) INNOTECH Regional Education Program. Philippines. 


\section{APPENDIX 1: TEACHER PROFESSIONAL DEVELOPMENT IN BANGLADESH}

$\mathrm{B}$ angladesh had a population of about 144 million as of 2011. The sprawling megacity Dhaka has a huge population, but the majority of the people still live in villages in rural areas. The urban population is around $28 \%$ of the total population. The rate of urbanization is 3.1\%. The literacy rate is rather low at an estimated $51.8 \%$ (7 years old and above), with $54.1 \%$ for males and $49.4 \%$ for females (BBS 2012). Over $98 \%$ of the people speak in the vernacular Bangla, but English is also widely spoken.

\section{A. Education System}

\section{Structure}

Education in Bangladesh has three major stages - primary, secondary, and higher education. Primary education is a 5-year cycle (grades 1-5) with two subsystems: general education and madrasah education. The first subsystem is secular in character and is open to people of all religions and castes, while the second subsystem is for Muslims only with focus on Islamic education along with some core general education subjects. The secondary stage is composed of three substages: junior (or lower) secondary, secondary (middle), and higher secondary. The junior secondary is a 3-year cycle (grades 6-8) with two subsystems like that of primary education (general and madrasah). The secondary (middle) substage is a 2-year cycle (grades 9-10), and higher secondary is also a 2-year cycle (grades 11-12). Higher secondary education in Bangladesh is also referred to as intermediate college. A third subsystem, technical-vocational education, begins in grade 9 and this is open to all people irrespective of religious beliefs. This subsystem, along with studies on some core subjects, offers courses in some technical, vocational, and trade subjects. The recent reforms noted in the National Education Policy (NEP) described under the section "recent reforms" will make the school education system a two-level system-primary and secondary. This will have significant impact on teacher development. Under this reform, there will be only primary and secondary teachers, which should help better manage the teacher development and supply challenges.

The entry age for primary education is 6 years. The junior secondary substage is designed for age group 11-13 years, secondary (middle) substage for age group 14-15 years, and higher secondary substage for age group 16-17 years. Higher secondary is followed by graduate-level education in general, technical, engineering, agriculture, business studies, and medical streams at universities. These are 3-5-year programs, except medicine, which takes 5-6 years to obtain a master's degree (it takes 5 years to get a Bachelor of Medicine and Bachelor of Surgery [MBBS] degree and an additional year to get a master's degree). 


\section{Education Expenditure}

According to date from 2011, the Government of Bangladesh spends only about 2.3\% of gross domestic product (GDP) on education, which is the lowest among the neighboring countries (Table A1.1). For example, Nepal allocates $4.6 \%$ of GDP for education; Bhutan, 4.8\%; and Maldives, $10.3 \%$. In terms of the share of annual budgetary allocation, education received about $9.0 \%$ in fiscal year (FY) 2011 (BANBEIS 2012).

\section{Table A1.1: Bangladesh-Share of Education in Gross Domestic Product and National Budget, 2011-2013}

\begin{tabular}{|l|r|r|r|}
\hline Indicators & \multicolumn{1}{|c|}{ FY2011 } & FY2012 & FY2013 \\
\hline Share of GDP in education (\%) & 2.3 & 2.5 & 2.06 \\
\hline Share of national budget in education (\%) & 9.0 & 12.2 & 11.17 \\
\hline Total education expenditure (Tk million) & 179,593 & 199,239 & \multicolumn{1}{|c|}{214,080} \\
\hline Total national budget (Tk million) & $1,998,769$ & $1,635,890$ & $1,917,380$ \\
\hline GDP in current market price (Tk million) & $7,874,950$ & $7,874,950$ & $10,379,867$ \\
\hline
\end{tabular}

$\mathrm{FY}=$ fiscal year, GDP = gross domestic product, $\mathrm{Tk}=$ taka.

Note: Bangladesh fiscal year is from 1 July to 30 June.

Source: Bangladesh Bureau of Educational Information and Statistics (BANBEIS). Basic Education Statistics 2011-2013. Dhaka. http://banbeis.gov.bd/new.

Table A1.2 shows the recurrent salary and nonsalary expenditures for different levels of education in 2010. Salaries for teachers and staff constituted more than $90 \%$ of recurrent expenditure for primary, secondary, and tertiary levels, with primary having the highest share at $98.6 \%$. The nontertiary level spent the lowest percentage on salary, $63.9 \%$. The figures do not include expenditures for incentives, in-service training, professional development, and resources to support teachers.

\section{Table A1.2: Bangladesh—Recurrent Salary and Nonsalary Expenditures by Level, 2010}

\begin{tabular}{|l|c|c|}
\hline \multirow{2}{*}{ Level of Education } & Share of Recurrent Expenditure (\%) \\
\cline { 2 - 3 } & Salary & Nonsalary \\
\hline Primary & 98.6 & 1.4 \\
\hline Junior secondary & 96.1 & 3.9 \\
\hline Upper secondary & 95.5 & 4.5 \\
\hline Nontertiary & 63.9 & 36.1 \\
\hline Tertiary & 91.3 & 8.7 \\
\hline
\end{tabular}

Note: Only the revenue budgets of public institutions are included.

Source: Bangladesh Bureau of Educational Information and Statistics (BANBEIS). Basic Education Statistics 2012. Dhaka. http://banbeis.gov.bd/new. 
Although the government spends a lot on in-service training to upgrade the quality of teachers, a system of continuing professional development is needed to help them constantly improve their professional skills. Continuing professional development, as a kind of in-service training, is a way for teachers to gain knowledge, skills, and attitudes in an incremental or progressive way through a series of planned training programs.

Performance of the subsector has been slowly improving over the last few years. Gross and net enrollment rates as well as survival and cycle completion rates have increased. In 2012, primary gross enrollment was $104.4 \%$ for both sexes. For boys, it was $101.3 \%$; for girls, $107.6 \%$. The net enrollment rate for both sexes was $96.7 \%$, with $95.4 \%$ for boys and $98.1 \%$ for girls. At the secondary level, the gross enrollment rate was 50.9\% for both sexes in 2012. For boys, it was $45.7 \%$, and for girls it was $56.6 \%$. The net enrollment rate for both sexes was $44.8 \%$; $41.4 \%$ for boys and $50.6 \%$ for girls (Table A1.3).

\section{Table A1.3: Bangladesh-Gross and Net Enrollment Rates in Primary and Secondary Education, 2010 (\%)}

\begin{tabular}{|l|c|c|c|c|}
\hline \multirow{2}{*}{ Gender } & \multicolumn{2}{|c|}{ Primary Grades } & \multicolumn{2}{c|}{ Secondary Grades } \\
\cline { 2 - 5 } & GER & NER & GER & NER \\
\hline Total & 104.4 & 96.7 & 50.9 & 44.8 \\
\hline Boys & 101.3 & 95.4 & 45.7 & 41.4 \\
\hline Girls & 107.6 & 98.1 & 56.6 & 50.6 \\
\hline
\end{tabular}

$\mathrm{GER}=$ gross enrollment rate, $\mathrm{NER}=$ net enrollment rate.

Source: Bangladesh Bureau of Educational Information and Statistics (BANBEIS). Basic Education Statistics 2012. Dhaka. http://banbeis.gov.bd/new.

The survival rate in primary education improved from 52.9\% in 2005 to $79.5 \%$ in 2011. The cycle completion rate also improved during that period, from $52.8 \%$ to $70.3 \%$ (Directorate of Primary Education 2012). In secondary education, the survival rate and the cycle completion rate indicate ups and downs over the years. The survival rate improved from 2005 to 2011 both for boys (from $60.6 \%$ to $63.9 \%$ ) and for girls (from $66.2 \%$ to $68.9 \%$ ). However, the cycle completion rate increased for boys but decreased for girls (BANBEIS 2011).

\section{B. Teacher Development, Recruitment, and Supply}

In 2011, there were 78,685 primary schools where 395,281 teachers taught $16,957,894$ students. The student-teacher ration was 43:1. About 49.2\% $(194,538)$ of the teachers were women. The percentage of female teachers was higher in public schools $(58.40 \%)$ than in private schools (38.54\%). At the secondary level, there were 223,555 teachers teaching $7,510,218$ students in 19,070 secondary institutions. The student teacher ratio was 34:1. Among the secondary-level teachers, $23.3 \%(52,001)$ are female and $76.7 \%(171,554)$ are male. The average number of students per institution in primary education was 216 , and 394 in secondary education. The average number of teachers per institution in primary education was 5.0; in secondary education it was 11.7 (Table A1.4). 
About $85 \%$ of primary school teachers have professional qualifications: Certificate in Education (C-in-Ed), Diploma in Education (Dip-in-Ed), Bachelor of Education (BEd), or Master of Education (MEd). For secondary school teachers, about $75.4 \%$ are trained (i.e., have some professional or pedagogical qualification such as Dip-in-Ed, BEd, or MEd). The percentage of trained female teachers $(77.4 \%)$ was slightly higher than that of the male teachers $(74.7 \%)$. The percentage of teachers serving in urban schools $(29.2 \%)$ was less than that in the rural schools (70.8\%). Most secondary school teachers hold bachelor's degrees (123,464 pass graduates; 14,116 honors graduates; 42,075 with master's degrees). Rural secondary schools have more teachers with a bachelor's or master's degree than do urban schools (Table A1.5).

\section{Table A1.4: Bangladesh—Number of Institutions, Students, and Teachers in Primary and Secondary Institutions, 2011}

\begin{tabular}{|c|c|c|c|c|c|c|c|c|c|c|c|}
\hline \multirow[b]{2}{*}{$\begin{array}{l}\text { Type of } \\
\text { Education }\end{array}$} & \multirow[b]{2}{*}{ Management } & \multirow[b]{2}{*}{$\begin{array}{l}\text { Number of } \\
\text { Institutions }\end{array}$} & \multicolumn{3}{|c|}{ Number of Teachers } & \multicolumn{3}{|c|}{ No. of Students } & \multicolumn{3}{|c|}{ Indicators } \\
\hline & & & Total & $\begin{array}{c}\text { Number } \\
\text { of } \\
\text { Females }\end{array}$ & $\begin{array}{c}\% \\
\text { Females }\end{array}$ & Total & $\begin{array}{c}\text { Number of } \\
\text { Girls }\end{array}$ & $\begin{array}{c}\% \\
\text { Girls }\end{array}$ & STR & SPI & TPI \\
\hline \multirow{3}{*}{$\begin{array}{l}\text { Primary } \\
\text { education }\end{array}$} & Public & 37,672 & 212,653 & 124,150 & 58.40 & $9,904,254$ & $5,071,252$ & 51.2 & 47 & 263 & 5.6 \\
\hline & Private & 41,013 & 182,628 & 70,388 & 38.54 & $7,053,640$ & $3,491,881$ & 49.5 & 39 & 172 & 4.4 \\
\hline & Total & 78,685 & 395,281 & 194,538 & 49.20 & $16,957,894$ & $8,563,133$ & 50.5 & 43 & 216 & 5.0 \\
\hline \multirow{3}{*}{$\begin{array}{l}\text { Secondary } \\
\text { education }\end{array}$} & Public & 317 & 7,562 & 2,869 & 37.94 & 228,242 & 107,482 & 47.1 & 30 & 720 & 23.9 \\
\hline & Private & 18,753 & 215,993 & 49,132 & 22.75 & $7,281,976$ & $3,918,892$ & 53.8 & 34 & 388 & 11.5 \\
\hline & Total & 19,070 & 223,555 & 52,001 & 23.26 & $7,510,218$ & $4,026,374$ & 53.6 & 34 & 394 & 11.7 \\
\hline
\end{tabular}

SPI = students per institution, $\mathrm{TPI}=$ teachers per institution, $\mathrm{STR}=$ student-teacher ratio.

a Secondary education is from grade 6 to grade 12, including the higher secondary sublevel.

Notes: For the higher secondary education level alone (grades 11-12), there were 1,928 institutions. STR was high at 50:1 in lower secondary level public schools and higher secondary grades or colleges. "Colleges" here pertain to the schools or institutions catering to higher secondary education. For public colleges (grades 11-12), STR was at 40:1. However, the STR for combined public and private higher secondary education was much lower at 1:15 because STR in private institutions was lower.

Source: Bangladesh Bureau of Educational Information and Statistics (BANBEIS). Basic Education Statistics 2012. Dhaka. http://banbeis. gov.bd/new. 


\section{Table A1.5: Bangladesh-Academic Qualifications of Secondary School Teachers}

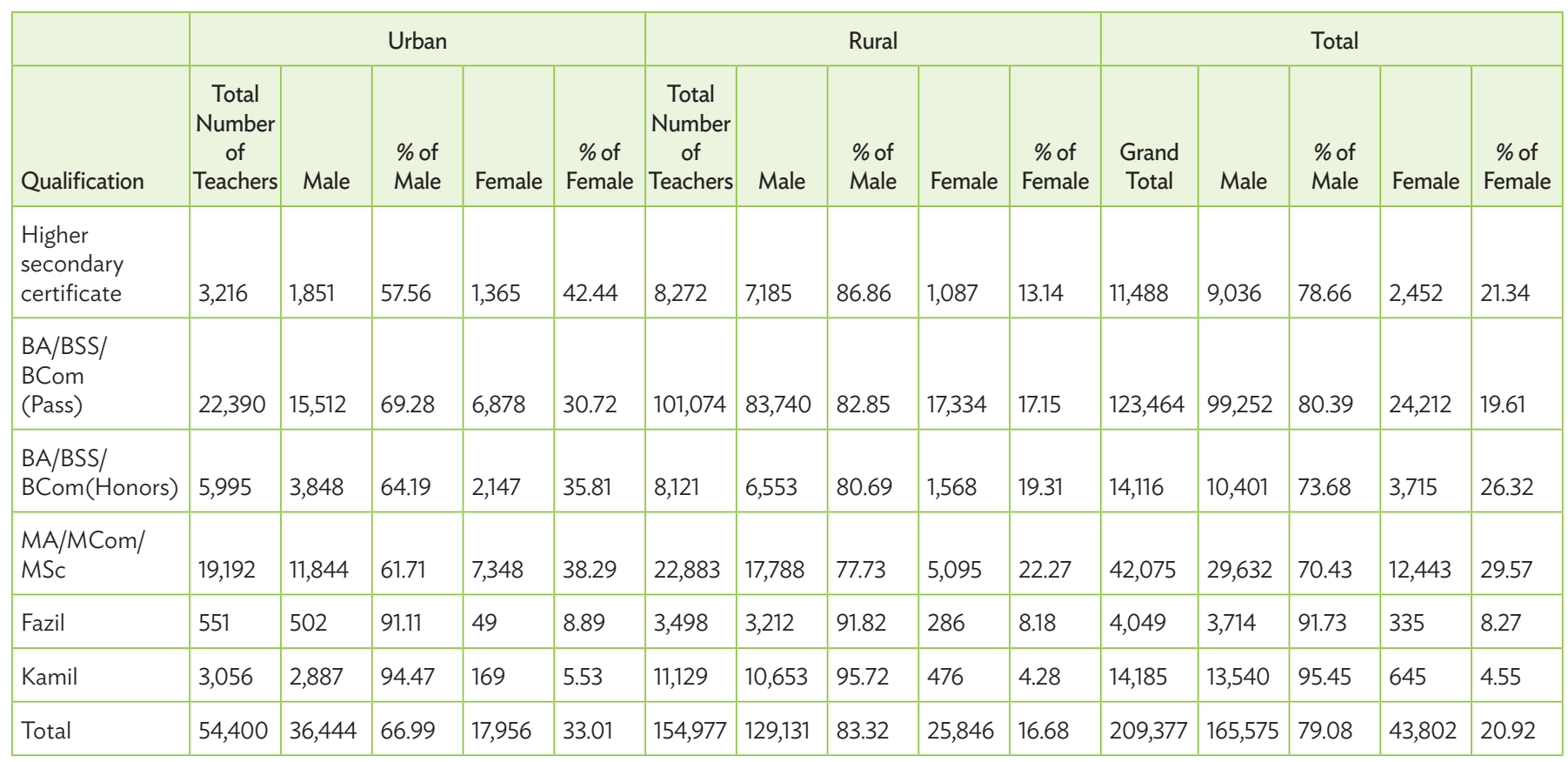

$\mathrm{BA}=$ Bachelor of Arts, $\mathrm{BCom}=$ Bachelor of Commerce, $\mathrm{BSS}=$ Bachelor of Social Science, MA = Master of Arts, MCom = Master of Commerce, MSc. = Master of Science.

Source: Bangladesh Bureau of Educational Information and Statistics (BANBEIS). Basic Education Statistics 2012. Dhaka. http://banbeis. gov.bd/new.

\section{Recruitment, Appointment, and Promotion of Teachers}

Teachers of government primary schools are recruited centrally through examinations conducted by the Directorate of Primary Education. The official preservice training necessary for a primary teacher is the $\mathrm{C}$-in-Ed. However, it is not compulsory for hiring. Teachers can also obtain a $\mathrm{C}$-in-Ed after their appointment. In effect, teachers are recruited and then sent for training on full salaries.

For the government primary schools, the request to fill vacant teaching posts originates at the school level. This is processed through the upazila (subdistrict) level and officers at the district level, and ends in the Directorate of Primary Education. The directorate recruits teachers through competitive examinations. Private primary schools, on the other hand, appoint teachers through school management committees. The student-teacher ratio at the primary level was 43:1.

Similarly, the demand for government secondary school teachers is processed through field officers at the district and upazila levels (e.g., district education officer, upazila secondary education officer). The teachers are recruited by the Public Service Commission through competitive examinations. There is no teacher professional examination. The Public Service Commission examination is for entry into government service. The teachers are employed through the Directorate of Secondary and Higher Education. 
The private secondary schools appoint teachers through school management committees. However, since establishment of the Nongovernment Teachers Registration and Certification Authority (NTRCA) in 2005, teacher candidates have been required to obtain registration from the NTRCA, which registers aspiring teachers for the secondary institutions annually through examinations. Only NTRCA-certified teachers are appointed, but since the NTRCA does not consider the pedagogical background of the candidates, many certified teachers are without a BEd. The NTRCA was supposed to be a national teacher registration and certification authority, but it was changed in terms of name and function. Such registration practice should not apply only to the private school teachers but to all teachers and as a national standard.

The student-teacher ratio at the secondary level was 30:1, which the government aimed to maintain until 2015 amid increasing enrollment in secondary education. The overall attrition rate depends on teachers retiring and otherwise leaving the system. There were no reliable data readily available except for teachers retiring from the system. Under the Teaching Quality Improvement-Secondary Education Project, the Secondary Teachers Information System, which includes a teacher database, was developed. It showed that the attrition rate is about $4 \%$.

Promotion of schoolteachers is very much restricted. Career paths are limited for both primary and secondary school teachers.

\section{Conditions of Employment}

"Working conditions" are generally defined as the socioeconomic and physical environment in which an employee is expected to complete his or her job. Teachers are often underpaid and under-supported in their need for instructional resources. Poor working conditions can lead to many negative issues for teachers and the students they educate, including depression, anger, and apathy.

In Bangladesh, the working conditions in government schools in general are better than in the private schools. For instance, the Secondary Teachers' Service Regulations of 1979 of the Ministry of Education (MOE) state for recognized nongovernment secondary school teachers their duties and functions as follows:

- teach the students in accordance with the curriculum, syllabus, and class routine by means of lesson notes, group discussions, demonstrations, etc.;

- make personal contacts with the students for their individual guidance;

- assist the school authorities in conducting examinations, organizing laboratories, and other curricular and cocurricular activities;

- supervise student extracurricular activities; and

- perform such other functions as may be assigned by the school management committee, or the headmaster, in the interest of the school.

The career path for private school teachers is very limited (Figure A1.1). Promotion to higher posts is difficult due to the small number of sanctioned posts. Similarly, public school teachers have limited opportunity to go beyond the position of headmaster. A career path will have to be developed. 


\section{Figure A1.1: Bangladesh—Career Path of Private School Teachers}

Source: Author.

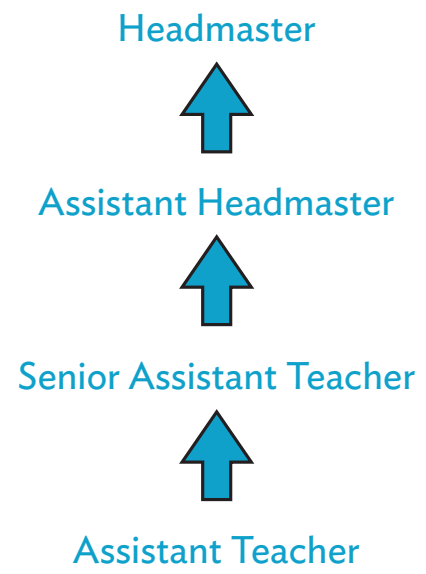

There are several common complaints from teachers about their work environments. Classroom size is one of them. Average classroom size in primary schools is 60 and that of the secondary schools is 72 . Many teachers do not get appropriate classrooms to teach their subjects (e.g., science classrooms). Teachers sometimes do not even have their own desks to store materials. Classroom facilities often are inadequate to meet the students' needs. Computers or internet access in the classroom is rare. Benefit packages are not sufficient for teachers to lead a decent life and, consequently, they must take up other jobs or run tutorials after school.

Many teachers leave the profession within the first 2 years, mainly because of working conditions or low pay. Right now, schools are not where well-educated college graduates want to work for a long time. The starting salary of a high school teacher is about $\$ 1,846$ per annum ${ }^{1}(144,000$ Bangladesh taka [Tk]) compared with the average income in Bangladesh of around $\$ 6,708$ per year in 2014 . The starting salary for primary school teachers is even less. This is one of the factors that lead to the lower status of teachers in society. Teachers often complain about their heavy course workloads, which makes it difficult to prepare for the next class. This lesson preparation and assessment of student work outside the classroom should, in fact, be factored in as part of their tasks to be done during working hours. The teachers of the public institutions are government employees, but their status is not on par with other government employees performing similar-level duties.

The most commonly mentioned factors that adversely affect job satisfaction and motivation among teachers in Bangladesh are as follows (Huq and Islam 2005):

(i) poor remuneration and other conditions of service;

(ii) unattractive school locations;

\footnotetext{
See Salary Explorer. Bangladesh. www.salaryexplorer.com/salary-survey.php?id=0-18-1.
} 
(iii) limited physical facilities (including lack of furniture);

(iv) lack of opportunities for further teacher training;

(v) heavy workloads;

(vi) virtually nonexistent promotion and career paths;

(vii) unruly student behavior;

(viii) problematic relationships with the community;

(ix) dysfunctional school management committees; and

(x) other school quality factors, including very limited teaching and learning resources.

Teachers in rural schools are even more disadvantaged because they teach in remote locations with poor communications. The facilities in rural areas are often so poor that teachers are not usually prepared to live near the school. Therefore, they commute long distances (often up to 30 kilometers), which leaves them tired and lacking energy for teaching. The government, in some cases, provides incentives for teachers to work in remote areas. Teachers working in hill districts get hill allowance. This incentive is available only for government school teachers. Unfortunately, such incentives have little impact on teachers' motivation to work in difficult places. Private schools do not have a system of teacher transfer among them. Teachers prefer to work in towns and cities where living conditions are better. When appointed to remote areas, they try to transfer to other places with better conditions.

However, because of job security, government teachers tend to have a better level of satisfaction and motivation than teachers from the private sector. Teachers in private schools depend entirely on the school management committee. While public and private school teachers have the same basic pay scale (Table A1.6), government teachers enjoy additional benefits such as house rent, medical allowance, provident fund, and so on. Many of the private schools, due to financial constraints, are not in a position to offer these benefits to their teachers. Table A1.7 shows comparative remuneration packages between government and nongovernment teachers. The allowances paid to nongovernment teachers are much lower, and when these are factored in, the income differential between the two groups of teachers becomes over $50 \%$. Annual salary increments are mainly based on the report of the institution's head. Promotion in government schools is based on length of service and the teacher's annual confidential report from the head of school and is processed through the Public Service Commission.

In the government schools, secondary school teachers are better off than primary school teachers because of better remuneration, lighter course loads, and greater scope of extra earnings from private tuition. Secondary school teachers are paid around a third more than primary school teachers. The income differential between trained and untrained primary school teachers is only $6 \%-8 \%$, which means that there is little financial incentive for untrained teachers to undertake the required pedagogical training. The income differential between head teachers and teachers is small at primary schools, but quite sizable at secondary schools. 
Table A1.6: Bangladesh-Basic Monthly Salary of Government Primary and Secondary School Teachers

\begin{tabular}{|c|c|c|c|}
\hline \multirow{2}{*}{\multicolumn{2}{|c|}{$\begin{array}{l}\text { Category of Teachers in Primary } \\
\text { and Secondary Schools }\end{array}$}} & \multicolumn{2}{|c|}{ Basic Pay (in taka) } \\
\hline & & \multirow{2}{*}{$\begin{array}{c}\text { Bottom Scale } \\
6,400\end{array}$} & \multirow{2}{*}{$\begin{array}{r}\text { Top Scale } \\
14,255\end{array}$} \\
\hline Primary ${ }^{a}$ & Trained head teacher & & \\
\hline & Untrained head teacher & 5,900 & 13,125 \\
\hline & Trained assistant teacher & 5,200 & 11,235 \\
\hline & Untrained assistant teacher & 4,900 & 10,450 \\
\hline \multirow[t]{3}{*}{ Secondary ${ }^{b}$} & Trained head teacher & 15,000 & 26,200 \\
\hline & Trained assistant teacher & 8,000 & 11,150 \\
\hline & Untrained assistant teacher & 6,400 & 9,305 \\
\hline
\end{tabular}

a Ministry of Primary and Mass Education.

${ }^{\mathrm{b}}$ Ministry of Education.

Sources: Ministry of Primary and Mass Education. Circular dated 9 March 2014; Ministry of Education. Circular dated 4 February 2010.

\section{Table A1.7: Bangladesh—Remuneration of Government and Registered Nongovernment Teachers, 2012}

\begin{tabular}{|c|c|c|}
\hline Type of Remuneration & Government Teachers & Nongovernment Teachers \\
\hline Basic salary & Eligible for basic salary & $\begin{array}{l}\text { Eligible for } 100 \% \text { basic salary but } \\
\text { sometimes disbursement is delayed }\end{array}$ \\
\hline House rent & As per government rule & Tk500/month (fixed) \\
\hline Medical allowance & Tk450 (fixed) & Tk300/month (fixed) \\
\hline Festival allowances & $\begin{array}{l}\text { Two festival allowances } \\
\text { (each equal to } 1 \text { month's } \\
\text { basic salary) every year } \\
\text { (during Eid and Puja) }\end{array}$ & $\begin{array}{l}\text { Two festival allowances per year } \\
\text { (only } 25 \% \text { of the basic salary each) }\end{array}$ \\
\hline Tiffin allowance & Tk100/month & Not eligible \\
\hline $\begin{array}{l}\text { Rest and recreation } \\
\text { allowance }\end{array}$ & $\begin{array}{l}\text { Equivalent to } 1 \text { month's basic } \\
\text { salary once every } 3 \text { years }\end{array}$ & Not eligible \\
\hline $\begin{array}{l}\text { Yearly increment and } \\
\text { efficiency bar }\end{array}$ & Eligible & Not eligible \\
\hline $\begin{array}{l}\text { Time-scaled salary } \\
\text { Increase }\end{array}$ & $\begin{array}{l}\text { After } 8,12 \text {, and } 15 \text { years of } \\
\text { service }^{\text {a }}\end{array}$ & $\begin{array}{l}\text { Eligible for a single time scale after } \\
8 \text { years }^{\mathrm{b}}\end{array}$ \\
\hline Pension & Eligible & Not eligible \\
\hline
\end{tabular}

Tk = Bangladesh taka.

${ }^{a}$ The value of an increment is one grade higher in the 20 -grade salary scale.

${ }^{b}$ Teachers who reach the end of the pay scale for their present designation and have 8 years of service to their credit then get the next higher salary scale without changing their present designation.

Source: BD news. http://bdnews24.com/. 
Although it is limited, the career path for government school teachers is still better than for private school teachers. Theoretically, a qualified primary or secondary government school teacher can obtain a higher administrative position at the Directorate of Primary Education or the Directorate of Secondary and Higher Education. This opportunity is not open to private school teachers.

Teacher professional development through in-service training is done mainly through different donor-funded education projects. The budgetary allocation for such training is inadequate. Teachers are not interested in taking in-service training because it is not linked to any incentive. In the absence of a teacher development policy, there is no system for teacher professional development in place.

\section{Teacher Quality Assurance}

\section{Minimum Quality Standards and Quality Monitoring}

Teacher quality can be interpreted in terms of different attributes such as general education, professional education, ability and competency to teach, and subject content knowledge. In Bangladesh, the minimum qualification for primary school teachers in terms of general education is a Higher Secondary Certificate (HSC) and for professional education, a C-in-Ed. Recently, an 18-month Dip-in-Ed program was introduced under the monitoring of the Institute of Education and Research of Dhaka University. The Dipin-Ed has just started, and there is no new circular issued yet including it as a required qualification for primary teachers. The program is yet to produce graduates.

The holder of an HSC can do some clerical jobs in many offices. But once an HSC degree holder chooses the teaching profession, he or she must obtain a C-in-Ed, which is a professional qualification needed for the teaching profession. The C-in-Ed course has some competency frameworks.

For secondary school teachers, the minimum qualification in terms of general education is a bachelor's degree in any general discipline, and for professional education, a BEd.

Though professional education is a vital attribute to become an effective teacher, there is no prohibition against appointing graduates without professional qualification (e.g., C-in-Ed or BEd). As mentioned earlier, teachers can be recruited first and then sent for training to obtain a C-in-Ed or BEd.

The process of selection, recruitment, and appointment of primary school teachers is done centrally by the Directorate of Primary Education. That of the secondary school teachers is done directly by the Directorate of Secondary and Higher Education for public schools or by the school management committee (SMC) for private schools. The Nongovernment Teachers Registration and Certification Authority has some valuable checklists for minimum "teacher quality" monitoring and assurance for private schools. However, this process has nothing to do directly with "teaching quality" monitoring or assessment of teaching competency. 
Monitoring and supervision are essential to ascertain and improve teachers' teaching competency. In the present system, monitoring of teaching is the official responsibility of the field-level education officers at the upazila (subdistrict) level. The examination boards (such as the Board of Intermediate and Secondary Education) also monitor schools to ensure the schools are maintaining the minimum standards required for affiliation with the board. But because of lack of funds for travel, school inspections by the Board of Intermediate and Secondary Education often do not happen. At the school level, the head teacher and the SMC are supposed to monitor the classroom performance of the teachers.

The Department of Inspection and Audit, working directly under the Ministry of Education (MOE), also inspects schools. However, their inspection is limited to the physical infrastructure and financial concerns and does not evaluate teacher performance.

There is no official set of indicators for good teacher performance. Generally, teachers of high-performing schools, based on students' passing records, are regarded as good teachers. Student examinations for promotion to higher grades are school-based. However, examinations at the end of grades 5, 7, 10, and 12 are national. The results of these examinations are used as proxy indicators to categorize performance of schools and teachers. The examination-conducting authorities (Directorate of Primary Education for the primary and the Board of Intermediate and Secondary Education for the secondary) hold the national examinations data. A detailed analysis of national patterns in teacher performance and high-performing schools may help identify practices that could be scaled up. Bangladesh does not take part in Trends in International Mathematics and Science Study or the Programme for International Student Assessment. Therefore, an international benchmark for education standards is not available.

\section{Institutional and Organizational Arrangement for Quality Monitoring}

Primary education is under the Directorate of Primary Education of the Ministry of Primary and Mass Education (MOPME). The directorate has administrative offices at the division, district, and upazila levels. ${ }^{2}$ Officers at the upazila primary education offices visit schools and classrooms, where they supervise and monitor teachers' classroom performance with the help of checklists.

The primary-level schools run by nongovernment organizations (NGOs), such as BRAC and Proshika, have their own system of supervision and monitoring. NGOs cater to approximately $20 \%$ of the primary school children. The monitoring and supervision in the NGO schools is very practical. The schools maintain a class size of 20-30 students; the supervisor is usually provided with transport (such as a bicycle or motorcycle) and has a small number of schools to supervise. Teachers get feedback regarding their performance in the class. Most of the good NGOs have their own cycle of training for the teachers' continuing professional development (CPD).

For secondary education, which is under the MOE, a number of organizations are involved in monitoring. Officers at the field level (e.g., district education officers, upazila secondary education officers) visit schools to monitor and supervise teacher's classroom performance.

2 About 20-30 primary schools form a cluster. The assistant upazila officer is in charge of a cluster. There are 3-6 clusters in an upazila depending on the area. 
The Board of Intermediate and Secondary Education and Department of Inspection and Audit officers also inspect schools for various purposes. The former monitors different aspects of a school necessary for affiliation. The Department of Inspection and Audit mainly inspects and audits school accounts and the upazila secondary education offices. In the absence of a national standard for teacher competency, the teacher's performance is rated against an official checklist or rating scale. In private secondary schools, the head teacher and the SMC members are responsible for monitoring teachers' classroom activities.

In principle, all of these activities are to maintain standards in the schools that, directly or indirectly, contribute to the quality of teaching and learning. However, it is reported that the school inspections by these organizations are mainly used to take administrative decisions such as school affiliation, budgetary allocations, school building renovation, and teachers' promotion - they are seldom used for quality improvement purposes. There should be more efforts to increase understanding of how to use these monitoring reports for planning and financing; for example, reports should feed into annual activity plans.

A number of teachers' associations at the primary and secondary levels are linked to national political parties. Their main concern is to look after the financial benefits of the teachers. They are not involved in the professional development of the teachers. Mainly due to the absence of a teacher development policy and lack of a legislative framework linking professional development to incentives or disincentives, there is also a lack of systematic teacher professional development. Student organizations are also present in higher secondary or college (grades 11 and 12) level. However, they do not articulate issues regarding teaching quality.

Local bodies such as the SMC (for schools), governing bodies (for colleges), and local education committees could provide assistance in improving teacher performance. This is not happening, however, due to the lack of policy on teacher professional development and strategic structure for monitoring and feedback on teacher quality and performance.

\section{Nongovernment Teachers Registration and Certification Authority}

While public school teachers are recruited through competitive examinations held nationally, the recruitment and appointment of private school teachers were previously left with the schools, a process sometimes tainted with issues of bias and nepotism. To resolve this, an examination and registration system for private school teachers was introduced through the Nongovernment Teachers Registration and Certification Authority (NTRCA) Law, which was enacted and passed in the National Assembly in 2005. The law makes it compulsory for all incumbent private school teachers to get registered. This has, to some extent, reduced bias and nepotism in the process of appointment of schoolteachers at the local level since registration is done through competitive examinations. Some element of quality is also ensured. Headmasters of the private schools reported that they get better teachers now. However, the National Education Policy 2010 recommended the establishment of a "Nongovernment Teachers Selection Commission (NTSC)" to eventually replace the NTRCA. The NTSC will be responsible for both nongovernment and madrasah teachers in an effort to rationalize teacher recruitment and deployment. 


\section{Provision of Teacher Education and Training}

\section{Teacher Education and Training Institutions}

The government has recently introduced a formal preprimary grade as integral part of primary education. However, there are no formal institutions for professional training of preprimary teachers. The government is encouraging private sector participation in this area. Some NGO-run primary schools provide training to their own teachers so they can teach preprimary grades - nursery, play group, and kindergarten 1 (KG-1).

For primary education, there are 54 government primary teacher training institutes (PTIs) providing preservice teacher education to primary school teachers. They offer a 1-year C-in-Ed course. PTIs also offer the new 18-month Dip-in-Ed in collaboration with the Institute of Education and Research of Dhaka University, which will handle the quality and monitoring of the program. At the upazila level, the upazila resource centers (URCs) organize subject-based training for primary school teachers. URCs are under the Directorate of Primary Education and are lodged in the campus of the model school in an upazila. So far, out of 481 proposed URCs, 174 (146 under the IDEAL Project and 28 under the Norway-supported PEDPQI) are now initially functioning.

The PTIs work under MOPME. The general administration is under the Directorate of Primary Education, while the academic aspects are looked after by the National Academy for Primary Education. The academy formulated the new Dip-in-Ed curriculum, monitors and supervises PTIs along with Institute of Educational Research at Dhaka University, conducts examinations, and publishes results. The PTIs and URCs are the training providers for the primary teachers. These institutions are monitored by the field-level officers and the National Academy for Primary Education.

For the professional preservice and in-service education and training of secondary teachers, there are the teacher training colleges (TTCs); Bangladesh Open University (BOU); departments or faculty of education in about a dozen private universities; higher secondary teacher training institutes (HSTTIs); technical TTCs; Bangladesh Madrasah Teachers' Training Institute; the Institutes of Education and Research in the University of Dhaka and the University of Rajshahi; and the Institute of Education, Research and Training in the University of Chittagong.

There are 18 government TTCs (including four colleges of physical education) and 104 nongovernment TTCs (including a TTC for physical education) to provide preservice and in-service teacher education. Two private universities also offer BEd programs. The usual duration of the BEd course is about 1 year. However, the BEd course in BOU has a 2-year duration because this is provided through distance education. BOU uses modular selflearning text materials, face-to-face tutorials, and assignments as instructional strategies, which take more time.

TTCs offer only one degree program, the BEd, mostly of 1-year duration. There are a few TTCs that offer BEd (Honors) and MEd. The 14 government and 104 private TTCs are under the academic and administrative control of the National University and the Directorate of Secondary and Higher Education (DSHE). The National University looks after the academic aspects (curriculum and examinations) and the DSHE looks after 
the administrative aspects (appointment, transfer, promotion, etc.) of the government TTCs. The National University and DSHE are the authorities responsible for quality assurance of secondary teacher education. The National University also offers affiliation to the 104 private TTCs, monitors their academic and administrative activities, conducts examinations, and awards degrees. The government TTCs are monitored and supervised by the training wing of the DSHE. The private TTCs are monitored and supervised by the National University authority.

There is no set standard for the government-managed training providers. ${ }^{3}$ The government-managed training providers enjoy many more facilities (physical infrastructure, academic, and others) than the private TTCs. However, the National University has set a minimal standard for establishment of a private TTC. The criteria are as follows:

(i) The TTC must be established on its own land. Documents related to land registration must be produced before the inspection team. The required size of land is as follows: (a) in metropolitan area, 1.0 acre (0.41 hectare); (b) in a municipal or industrial area 1.5 acres ( 0.61 hectare); and (c) in other areas, 2.0 acres ( 0.81 hectare).

(ii) There should be an adequate number of rooms for running administration, eight classrooms with 700 square feet (about 65 square meters) area, separate common rooms for male and female teachers, common rooms for male and female students, a seminar room, and an auditorium.

(iii) There should be adequate furniture for the teachers.

(iv) The principal of the college must have a BEd. There should be two teachers per subject. At least $80 \%$ of teachers should be full-time. Teachers must be recruited following the regulation for nongovernment degree college teachers.

(v) There should be pay scales following the government regulation for teachers and other staff of the TTC. The college should be able to pay the salaries of the working teachers and other personnel regularly.

(vi) The college should have Tk300,000 as a reserve fund and Tk200,000 in the general fund. Documents in support of the reserve fund must be deposited to the university before getting affiliation. Affiliated colleges will need prior permission to withdraw money from the reserve fund.

(vii) The financial status and overall management of the college must be satisfactory.

(viii) The college must have a good library with a reading room. There must be 3,000 books in the library related to the BEd curriculum and syllabus.

(ix) There should be adequate equipment and apparatus necessary for practical classes. The college should have a laboratory school for practice teaching.

(x) The college should have its own playground for students to play.

(xi) Permission will not be given to establish more than one college in a locality.

(xii) There should be residential arrangements near the college campus for the principal, vice principal, teachers, and other staff. There must be a student hostel.

(xiii) There should be a governing body to run the college.

(xiv) There must not be a second campus of the college.

\footnotetext{
3 Private and public TTCs follow the same curriculum, and academic rules and regulations are the same for both. But the private TTCs do not strictly follow them, sometimes compromising the standard for BEd graduates.
} 
(xv) If any college admits students before getting affiliation from the university, its application for affiliation will be canceled and the money deposited for affiliation will be confiscated.

(xvi) Contractual appointment of retired TTC teachers will get preference.

(xvii) The college office must have computers, printers, and an internet connection.

There are five higher secondary teacher training institutes located at Barisal, Comilla, Khulna, Mymensingh, and Rajshahi. These provide short-term training courses with a usual duration of 56 days for higher secondary teachers (grades 11-12). These institutions offer subject-based in-service courses for college teachers. The institutes are under the administration of the MOE and the DSHE. The main objectives of such training are (i) to develop the professional skills of higher secondary teachers, (ii) to motivate and train the teachers in their attitude toward improving the quality of higher secondary education, (iii) to motivate teachers to solve educational problems in educational institutions, (iv) to familiarize teachers with the updated syllabus, (v) to help teachers adapt to changes in the management of higher secondary education, and (vi) to carry out any training task given by the MOE and the DSHE.

For technical and vocational institution teachers, there is only one technical teachers' training college providing a 1-year diploma and 2-year degree courses. For madrasah teachers, the Bangladesh Madrasah Teachers' Training Institute was founded by the MOE through the Establishment of a Madrasah Teacher Training Institute project in 1995. The institute offers a 1-year BEd program for the madrasah teachers that is equivalent to the BEd course offered by the TTCs. It also provides 1-month training courses in functional Arabic, communicative English, and mathematics.

The Institute of Educational Research in the University of Dhaka offers a 4-year BEd (Honors) program. It also provides a 1-year MEd course as well as an MPhil and PhD in Education. The 4-year BEd (Honors), which is a more advanced course than the BEd, is in the process of being officially recognized as a requisite qualification for secondary school teachers. The institute offers specializations in (i) science, mathematics, and technology education; (ii) language education; (iii) social science education; (iv) educational psychology and guidance; (v) educational research; (vi) nonformal education; (vii) primary education; (viii) curriculum and technology education; (ix) educational administration; and (x) special education. Other institutions offering the 4-year BEd academic honors course in education are Rajshahi University and Chittagong University, along with some TTCs and a few private universities. This is not the usual BEd training course offered by TTCs.

Universities are not very actively involved in teacher education and training. Very few universities offer BEd courses. The research on education they conduct is also purely academic (for obtaining degrees) and not a part of the government-planned teaching quality development process.

Table A1.8 summarizes the types and numbers of teacher training institutions in Bangladesh. 


\section{Table A1.8: Bangladesh-Characteristics and Criteria of Different Types of Teacher Training Institutions}

\begin{tabular}{|c|c|c|c|c|c|c|}
\hline \multicolumn{2}{|c|}{$\begin{array}{l}\text { Type and Number of Teacher } \\
\text { Training Institution }\end{array}$} & \multirow{2}{*}{$\begin{array}{l}\text { Entry } \\
\text { Requirements } \\
\text { for Student } \\
\text { Teachers } \\
\text { Higher } \\
\text { Secondary } \\
\text { Certificate }\end{array}$} & \multirow{2}{*}{$\begin{array}{l}\text { Duration } \\
1 \text { year }\end{array}$} & \multirow{2}{*}{$\begin{array}{c}\text { Final } \\
\text { Examination } \\
\text { (Internal, } \\
\text { External) } \\
40: 60^{a}\end{array}$} & \multirow{2}{*}{$\begin{array}{l}\quad \begin{array}{c}\text { Degree } \\
\text { Awarded or } \\
\text { Qualification } \\
\text { Granted }\end{array} \\
\text { Certificate in } \\
\text { Education }\end{array}$} & \multirow{2}{*}{$\begin{array}{c}\begin{array}{c}\text { Target } \\
\text { Education } \\
\text { Levels }\end{array} \\
\text { Primary }\end{array}$} \\
\hline Government PTIs & $54 \mathrm{PTIs}$ & & & & & \\
\hline \multirow[t]{2}{*}{$\begin{array}{l}\text { Nongovernment } \\
\text { organizations }^{b}\end{array}$} & Primary & $\begin{array}{l}\text { Secondary } \\
\text { School } \\
\text { Certificate } \\
\text { and/or Higher } \\
\text { Secondary } \\
\text { Certificate }\end{array}$ & weeks & $\mathrm{N} / \mathrm{A}$ & $\begin{array}{l}\text { Course } \\
\text { completion } \\
\text { certificate }\end{array}$ & $\begin{array}{l}\text { Primary, } \\
\text { lower } \\
\text { secondary }\end{array}$ \\
\hline & Secondary & $\begin{array}{l}\text { Bachelor's } \\
\text { degree }\end{array}$ & 1 month & N/A & $\begin{array}{l}\text { Course } \\
\text { completion } \\
\text { certificate }\end{array}$ & $\begin{array}{l}\text { Lower } \\
\text { secondary }\end{array}$ \\
\hline \multirow[t]{2}{*}{$\begin{array}{l}\text { Government } \\
\text { teachers' training } \\
\text { institutes }\end{array}$} & $\begin{array}{l}14 \text { teachers' } \\
\text { training } \\
\text { colleges }\end{array}$ & BSS, BSc, BBA & 1 year & $40: 60^{a}$ & $\begin{array}{l}\text { Bachelor in } \\
\text { Education }\end{array}$ & $\begin{array}{l}\text { Lower and } \\
\text { upper } \\
\text { secondary }\end{array}$ \\
\hline & $\begin{array}{l}5 \text { higher } \\
\text { secondary } \\
\text { teachers' } \\
\text { training } \\
\text { institutes }\end{array}$ & $\begin{array}{l}\text { College } \\
\text { teacher }\end{array}$ & 2 weeks & N/A & $\mathrm{N} / \mathrm{A}$ & $\begin{array}{l}\text { Higher } \\
\text { Secondary }\end{array}$ \\
\hline $\begin{array}{l}\text { Private teacher } \\
\text { training institutes }\end{array}$ & $\begin{array}{l}104 \text { teachers' } \\
\text { training } \\
\text { colleges }\end{array}$ & $\begin{array}{l}\text { BSS, BSc, } \\
\text { or BBA }\end{array}$ & 1 year & $40: 60^{a}$ & $\begin{array}{l}\text { Bachelor in } \\
\text { Education }\end{array}$ & $\begin{array}{l}\text { Lower } \\
\text { and upper } \\
\text { secondary }\end{array}$ \\
\hline $\begin{array}{l}\text { Universities/ } \\
\text { colleges }\end{array}$ & $\begin{array}{l}2 \text { Institutes of } \\
\text { Education and } \\
\text { Research } \\
1 \text { Bangladesh } \\
\text { Open } \\
\text { University }\end{array}$ & $\begin{array}{l}\text { Higher } \\
\text { Secondary } \\
\text { Certificate } \\
\text { Higher } \\
\text { Secondary } \\
\text { Certificate }\end{array}$ & $\begin{array}{l}4 \text { years } \\
2 \text { years }\end{array}$ & N/A & $\begin{array}{l}\text { Bachelor in } \\
\text { Education } \\
\text { (Honors) } \\
\text { Bachelor in } \\
\text { Education }\end{array}$ & $\begin{array}{l}\text { Lower } \\
\text { and upper } \\
\text { secondary } \\
\text { Lower } \\
\text { and upper } \\
\text { secondary }\end{array}$ \\
\hline
\end{tabular}

$\mathrm{BBA}=$ Bachelor of Business Administration, $\mathrm{BSc}=$ Bachelor of Science, BSS $=$ Bachelor of Social Science, N/A = not applicable, $\mathrm{PTI}=$ primary teacher training institute.

a Internal marks (40\%) through assignments, projects etc.: examination (60\%) conducted centrally by the National University.

bSome nongovernment organizations are working in the field of nonformal primary and secondary education but their number has not been ascertained.

Source: Adapted from BANBEIS Report 2012. 


\section{Professional Education Programs for Secondary Education Teachers}

The curriculum of the BEd degree offered by TTCs through the National University is structured into the following five learning areas: (i) professional studies, (ii) education studies, (iii) technology and research studies, (iv) teaching practice, and ( $v$ ) teaching studies. Table A1.9 shows the contents and the corresponding maximum marks for each subject.

\section{Table A1.9: Bangladesh—Courses of Bachelor of Education Curriculum (1-Year Program)}

\begin{tabular}{|c|c|c|}
\hline Compulsory Subjects & Contents & Marks (Maximum) \\
\hline Professional studies (one course) & (1) Essential teaching skills & 100 marks \\
\hline Education studies (two courses) & $\begin{array}{l}\text { (2) Secondary education, curriculum, and child } \\
\text { development } \\
\text { (3) Learning, assessment, and reflective practice }\end{array}$ & $\begin{array}{l}100 \text { marks } \\
100 \text { marks }\end{array}$ \\
\hline $\begin{array}{l}\text { Technology and research studies } \\
\text { (two half courses) }\end{array}$ & $\begin{array}{l}\text { (4a) Basic computer skills } \\
\text { (4b) Action research (in English) }\end{array}$ & $\begin{array}{l}50 \text { marks } \\
50 \text { marks }\end{array}$ \\
\hline Teaching practice (two courses) & $\begin{array}{l}\text { Teaching practice } 1 \text { and teaching practice } 2 \\
\text { students do school-based practice teaching and a viva } \\
\text { voce }\end{array}$ & $\begin{array}{l}250 \text { marks } \\
50 \text { marks }\end{array}$ \\
\hline $\begin{array}{l}\text { Teaching studies (10 elective }+5 \\
\text { optional courses) }\end{array}$ & $\begin{array}{l}\text { Select one (maximum two) elective courses from the } \\
10 \text { electives, and one optional course from the five } \\
\text { optional courses }\end{array}$ & \multirow{3}{*}{$\begin{array}{l}\text { Total of } \\
300 \text { marks } \\
\text { (two courses } \\
\text { each of } \\
150 \text { marks) }\end{array}$} \\
\hline $\begin{array}{l}\text { Elective teaching studies courses- } \\
\text { Group A }\end{array}$ & $\begin{array}{l}\text { Teaching Bangla } \\
\text { Teaching business studies } \\
\text { Teaching English (in English) } \\
\text { Teaching mathematics } \\
\text { Teaching science }\end{array}$ & \\
\hline $\begin{array}{l}\text { Elective teaching studies courses- } \\
\text { Group B }\end{array}$ & $\begin{array}{l}\text { Select one from the following, unless two are selected } \\
\text { from Group A: } \\
\text { Teaching social science } \\
\text { Teaching religious studies } \\
\text { Teaching agricultural studies } \\
\text { Teaching home economics } \\
\text { Teaching information and communication technology }\end{array}$ & \\
\hline Optional teaching studies courses & $\begin{array}{l}\text { One of the following may be selected as an optional or } \\
\text { additional course: } \\
\text { Teaching art and craft } \\
\text { Teaching health, sports, and physical education } \\
\text { Teaching music } \\
\text { Teaching commercial geography } \\
\text { Library science }\end{array}$ & $\begin{array}{l}100 \text { marks } \\
\text { (marks above } 40 \\
\text { are added to the } \\
\text { total marks) }\end{array}$ \\
\hline
\end{tabular}

Note: The subject content for the Bachelor of Education degree is prepared by National University.

Source: National University. BEd Curriculum 2010. 
Since one of the objectives of the BEd is to produce effective and quality secondary school teachers, the content of the BEd curriculum is validated for relevance against the content of the secondary school curriculum. Through the practice teaching component of the course, the student teachers are familiarized with the school situation. They follow the school curriculum, use the learning materials developed for the students, and assess them.

Higher secondary teacher training institutes (HSTTIs) provide a 56-day training with the following components: (i) education policy and management; (ii) educational psychology; (iii) methods and education technology; (iv) assessment and evaluation in education; (v) subject learning and teaching; (vi) action research and field trips; (vii) practice teaching (micro-teaching and simulation); and (viii) physical training, cocurricular activities, library and computer literacy, and communicative language (English). There are many grades 11-12 teachers who have never received this training.

\section{E. Programs and Projects for Teacher Education Reform}

\section{Major Interventions}

The Government of Bangladesh has implemented a number of education projects with assistance from development partners such as the Asian Development Bank (ADB), Department for International Development of the United Kingdom, the Japan International Cooperation Agency, and the World Bank. These projects aim to improve access and quality of education in general. Most of these interventions have teacher development components. Some of these programs and projects and their objectives are given in the following.

a. Teaching Quality Improvement in Secondary Education Project The overall objective of this project was to improve the quality of education through improving teacher education and training facilities. Major accomplishments of the project implementation are as follows:

(i) Physical facilities of all TTCs, HSTTIs, and the National Academy of Educational Management were improved.

(ii) Outreach centers were established in disadvantaged locations such as Patuakhali, Rangamati, and Thakurgaon without any teacher education or training facilities.

(iii) A total of 4,618 master trainers were developed to conduct in-service training for secondary school teachers.

(iv) A total of 201,004 secondary school teachers received a 14-day in-service training as a part of continuing professional development (CPD) training.

(v) English teachers received a 24-day special CPD training.

(vi) A total of 119,807 teachers received a 5-day refresher CPD training from TTC and district education officers.

(vii) A total of 99,957 teachers who had received CPD-I and CPD-II training programs received CPD-III training under locally arranged cluster training programs.

(viii) Head teachers received 21-day and 6-day follow-up retraining programs on professional competency and skills development from teacher training institutes. 
(ix) A total of 1,537 new head teachers received 35-day preservice head teacher training from five HSTTIs.

(x) A total of 15,757 secondary school teachers (including 1,000 madrasah teachers) who had no formal teacher training received a 3-month secondary teaching certificate course under the National University. Among them, 1,228 teachers later completed the 9-month BEd course.

(xi) A unified BEd course for all public and private teacher training institutes and Bangladesh Open University was introduced. Necessary teaching-learning materials and guides have been developed and distributed free in all teacher training institutes. The teachers of the teacher training institutes appreciated the unified BEd course under the project.

(xii) Teachers in the remote locations of Barisal, Chittagong, Noakhali, and Thakurgaon districts received special distance training using mobile telephones.

(xiii) Workshops were organized in 58 districts to create social awareness among people of different classes and professions on gender and a unified education system.

(xiv) A total of 53,826 head teachers and school management committee members received a 2-day training in upazila headquarters to develop awareness of gender issues and a unified education system.

(xv) Selected trainer teachers of 14 TTCs conducted mobile monitoring of teachers' classroom performance using ICT-equipped vans supplied under the project and provided on-site demonstration lessons.

(xvi) The project introduced the Innovation Development Fund for TTCs, HSTTIs, universities, and schools, and 129 projects were undertaken.

The project ended in September 2012. An evaluation study based on classroom observation, conducted under the Teaching Quality Improvement-Secondary Education Project, assessed teaching quality using a quality index. The overall teaching index was assessed as 3.86, with 4.04 for male teachers and 3.56 for female teachers. It has improved compared with the pre-implementation baseline index of 2.36 for male teachers and 1.91 for female teachers, indicating significant improvement of the teachers through the project training.

The Second Teaching Quality Improvement in Secondary Education Project (TQI-II) has been set for implementation for 2012-2017. It aims to build on achievements of the first Teaching Quality Improvement Project to further improve the quality of teaching and learning in secondary education institutions by strengthening a quality assurance system for training, recruitment, and performance monitoring of secondary teachers, in line with agreed policies in the National Education Policy of 2010. All new teachers, and most of the incumbent teachers, are expected to achieve secondary teacher registration by 2016.

\section{b. Secondary Education Sector Development Project}

The Secondary Education Sector Development Project aimed at improving the efficiency and quality of secondary education through enhancing access; improving performance monitoring systems to enhance functionality in education management, widespread use of ICT, increased education quality through revised curriculum, and better student assessment practices; and increasing equality of education opportunities for girls and indigenous peoples. The project has a component to help develop madrasah education. 
The key achievements and reforms initiated by these projects are upgraded secondary (grades 6-10) and higher secondary (grades 11-12) curriculum, development of curricular materials, and training of subject teachers on the development and use of creative questions.

\section{c. Secondary Education Quality Access Enhancement Project}

The project focuses on two very important areas: increasing access to poor girls and boys, and improving secondary school educational performance, with emphasis on English language and mathematics. The key outcomes and reforms initiated by these projects are as follows: (i) trained English and mathematics teachers on producing text materials and lesson plans and using them effectively in the classrooms; (ii) introduced incentive awards to students, teachers, and institutions; (iii) provided stipends and tuition to poor boys and girls; and (iv) improved monitoring and evaluation.

\section{Good Examples from Completed Project}

\section{a. Secondary Teaching Certificate}

A bachelor's degree from a recognized university is a requirement for admission into TTCs for a BEd degree. However, many previously recruited school and madrasah teachers do not possess the required qualification for admission into TTCs. The Teaching Quality Improvement-Secondary Education Project formulated a 3-month Secondary Teaching Certificate course for these teachers. The course is conducted in government TTCs. After completion of the 3-month course, teachers will get a certificate from the National University that will qualify them for admission to TTCs for a 9-month BEd course. Upon successful completion of the 9-month course, teachers will sit for an examination to obtain a BEd degree. Since these are in-service training courses, teachers receive full salary. A total of 15,757 secondary school teachers (including 1,000 madrasah teachers) who had no formal training in teaching received a 3-month Secondary Teaching Certificate under the National University. Among them, 1,228 later completed the 9-month BEd course.

\section{b. Fund for Innovative Projects and Programs in Teacher Education and Training} The TQI-II project introduced some innovative programs for TTCs, HSTTIs, universities, and schools. As of June 2011, 138 Innovative Development Fund (IDF) applications had been received and 129 were approved for support. Out of these, 118 projects are already completed. Approximately $20 \%$ of approved IDF proposals focused on school monitoring and mentoring. Teacher educators from TTCs monitored about 200 schools. Initial assessment of these projects found that IDF interventions have improved TTC capacity to support outreach activities including school-level monitoring and mentoring of teachers. Several IDF projects focused on use of the internet for teaching and learning processes, which helped the teachers and students become more computer literate.

\section{c. In-Service Training through Mobile Phones}

Teachers in remote locations in Barisal, Chittagong, Noakhali, and Thakurgaon districts received special distance training using mobile telephones. The Teaching Quality Improvement-Secondary Education Project supported the study through its IDF. No study on its impact has been done yet. 


\section{d. National Teacher Education Council}

The establishment of the National Teacher Education Council (NTEC) is an important step forward toward qualitative improvement of teacher education and training in the country. The NTEC came into existence through a circular dated 17 February 2010. The fields of work of the council are as follows:

(i) Develop and implement a functional structure to control the quality of the country's teacher education and training.

(ii) Determine and implement similar national standards for all teacher education and training institutions of the country.

(iii) To ensure quality teacher education and training, determine a functional quality control mechanism and in the light of the determined national standards, regularly and continuously observe, monitor, and evaluate whether the teacher education and training institutions are properly conducting their programs.

(iv) Ensure adherence to the rules and regulations of the quality control framework.

(v) Ensure professional development of the academic, technical, and administrative personnel of the teacher education and training institutions.

(vi) Facilitate necessary coordination among all teacher education and training institutions and establish networking and linkage among them.

(vii) The council can take up any program or activities it deems necessary to achieve the objectives of the council.

(viii) The chair of the NTRCA will work as the secretary of the council.

\section{F. Analysis of the Teacher Education and Training System}

\section{Recent Reforms and Initiatives}

One of the recent major reforms in teacher education occurred through the Secondary Education Sector Improvement Project in 2004, when the BEd curriculum was updated and the duration of the course was increased from 10 months to 1 year. In 2005, the NTRCA was established through assistance under the Teaching Quality ImprovementSecondary Education Project. Registration in the NTRCA was made compulsory for the incumbent teachers of the private (nongovernment) secondary schools.

In 2010, the National Education Policy (NEP), a comprehensive education policy framework, was approved by the National Assembly. It contains concepts, strategies, and directions for the improvement of quality and expansion of education in Bangladesh. The NEP recognizes that teachers are a crucial pillar of the education system that aim to produce educated, motivated, and competitive workers needed for the overall development of the country. Among the major reforms provided in the NEP is the restructuring of the three-tier (primary, secondary, and higher secondary) school education system into two tiers (primary and secondary). The duration of primary education is proposed to be extended from grades $1-5$ to grades $1-8$. Thus, the secondary level will comprise grades 9-12. However, the education committee that formulated the NEP 2010 did not consider the implications of this reform on the teacher education system. When this reform takes effect, the teacher education and training structure and management will have to follow in 
strategic transition so as not to adversely affect teacher supply. Another important matter to consider is formal preservice education and training for preschool teachers. Presently, preschool teachers are prepared through the in-service training components of the different education projects.

The NEP 2010 also recommended establishment of the NTEC, which would be responsible for setting policy and standards on teacher education and training and function as the highest authority to improve the quality of teachers. Through legislation, the NTEC was established and commenced its work in 2010. At present, most of the NTEC's staff are on deputation. It needs restructuring in terms of leadership and staffing to ensure that it is run only by professionals and experts. The NTEC will work closely with the proposed NTSC to recruit competent teachers.

Despite the strong emphasis on teacher quality improvement in the NEP, teacher education and training did not get much attention in terms of planning and budget. Teachers were given occasional refresher courses depending on the availability of funds from the ministry and development projects. To date, there is no development policy specific for teacher education and professional development. This urgent task now falls under the responsibility of the NTEC.

Teacher development infrastructure is still insufficient and needs proper planning and restructuring. The $54 \mathrm{PTI}$ are not enough to meet the ever-increasing demand for trained primary school teachers (12 more PTIs will be built). Some NGOs, such as $B R A C$ and PROSIKA, are training their own teachers. Many philanthropists as well as "business-minded" people are establishing primary schools, especially under the name "kindergartens." However, most of these are run by untrained teachers. Similarly, there is a gap between the demand and supply of secondary-level teachers in Bangladesh. ${ }^{4}$ The 118 TTCs are not enough to produce the required number of trained secondary school teachers. Meeting demand for teachers in subjects such as English, mathematics, and science is also difficult. Hence, there is a need to explore options for involving other providers to widen access to teacher education, introduce competition, and improve quality and costs of training.

All TTCs (government and private) are under the National University, which is a nonteaching (only affiliating) university, and due to lack of a proper monitoring mechanism, the quality of the preservice BEd degree is in question. The TQI-II project is set to review and update the BEd curriculum to make it relevant to the needs of 21 st century teaching practices.

At present, PTIs train teachers of primary level (grades 1-5); TTCs train teachers of secondary level (grades 6-10); and HSTTIs provide teachers of higher secondary level (grades 11-12) with short-term training. However, with the government's plan to restructure the education system, PTIs are not able to train the new primary teachers, who will now teach from the preprimary stage to grade 8 . The present academic personnel of PTIs do not have the education background and preparation to train teachers for grades $6-8$. The PTIs' teacher education curriculum needs to be reoriented. This concern is on top of many

4 According to ADB (2010). 
other existing issues related to finance, administration, and management. Likewise, the educational backgrounds and pedagogical preparation of the academic staff in TTCs are not adequate to train teachers for grades 11-12. Close collaboration between TTCs and HSTTIs is important to resolve these problems.

Involvement of the universities in the teacher development system is negligible, mainly due to lack of a relevant government policy framework that encourages better participation. It does not help that the University Grants Commission has been silent in this regard. There is also a need to develop and enhance research capabilities of the teacher training institutions. Linking PTIs and TTCs to the universities is expected to help achieve this.

Resolving this complicated situation in the country's teacher education and training system must begin with a clear policy framework on which planning and budget allocation will be based.

\section{Relevance of the Current Teacher Development System: Economy and Quality}

To date, there is no education law in effect. The government is in the process of developing an education act (a draft act has been prepared), as well as a teacher development policy. The process includes extensive consultation with various stakeholders. At present, however, there is a policy vacuum that has serious implications on all aspects of teacher development and supply. For one thing, there is an urgent need for an official standard or competency profile for teachers. It has become the mandate of the NTEC to set national standards for teacher competencies. However, the NTEC is under review. The TQI-II project engaged one national and one international consultant to assess the NTEC and recommend measures to make it more functional in this respect.

Results of the public examinations show that teachers are, to some extent, successful in their endeavor to equip students with the knowledge, skills, and attitudes as prescribed in the curriculum. However, the curriculum is more oriented toward obtaining good marks than toward the world outside school. Employers, in general, complain that the curriculum as implemented does not really prepare students for the world of work.

The teacher education curriculum is aimed at producing efficient and competent classroom teachers. Therefore, the teacher education curriculum should be linked to the school curriculum. If the school curriculum is responsive to the demands of the labor market, then the teacher education curriculum should aim to produce teachers with competencies oriented toward this objective. Systematic follow-up studies will help validate the curriculum's effectiveness.

The needed research capability in the field of teacher education is yet to be developed. Research by master's degree students is purely academic and oriented toward obtaining the degree. Neither the MOE nor the DSHE has a research unit for doing follow-up studies to improve various aspects of education. Most studies are conducted under different education projects, which mainly involve doing baseline studies and then follow-up studies to determine the impact of the project. 


\section{Relevance of the Current Teacher Development System: Access and Equity}

Table A1.10 shows enrollments in primary and secondary teacher education and training institutions in 2010. ${ }^{5}$ Figures indicate lower enrollment of females in preservice teacher education in both the primary and secondary levels. Total PTI enrollment was 13,266 , of which about 39.7\% were women. At TTCs, enrollment for 2010 was 19,248, with 38.5\% women. Of the total, about $64.5 \%$ are enrolled in private TTCs. The gap between demand and supply of teachers at the secondary level was approximately 7,000 teachers as of 2010 (ADB 2012b). The pass rates in these institutions are high (more than 90\%). Despite this high output, the supply of professionally qualified teachers falls short of demand for both levels.

Participation of women in teacher education is still low. The percentage of female teachers in the TTCs (both public and private) was only about 38.5\%. There is, however, one TTC in Mymensingh exclusively for female trainees.

\section{Table A1.10: Bangladesh—Enrollment in Teacher Education Institutions, 2010}

\begin{tabular}{|l|c|c|c|c|c|c|c|c|c|}
\hline \multirow{2}{*}{$\begin{array}{l}\text { Type of } \\
\text { Institution }\end{array}$} & \multicolumn{3}{|c|}{ Public } & \multicolumn{3}{c|}{ Private } & \multicolumn{3}{c|}{ Total } \\
\cline { 2 - 11 } & Total & Female & $\%$ & Total & Female & $\%$ & Total & Female & $\%$ \\
\hline $\begin{array}{l}\text { Primary } \\
\text { training } \\
\text { institute }\end{array}$ & 13,266 & 52,72 & 39.74 & n/a & n/a & n/a & 13,266 & 5,272 & 39.74 \\
\hline $\begin{array}{l}\text { Teacher } \\
\text { training } \\
\text { college }\end{array}$ & 6,824 & 3,006 & 44.05 & 12,424 & 4,412 & 35.51 & 19,248 & 7,418 & 38.54 \\
\hline
\end{tabular}

$\mathrm{n} / \mathrm{a}=$ not applicable.

Source: Table 5.7 in Bangladesh Bureau of Educational Information and Statistics (BANBEIS). Basic Education Statistics 2012. Dhaka. http://banbeis.gov.bd/new.

There were 629 teachers in PTIs and 1,594 in all TTCs (Table A1.11). The aggregate student-teacher ratio is acceptable in PTIs but very low in TTCs. However, actual variation in the ratio should be examined across all institutions to determine the distribution pattern of teachers. The PTIs (54) and the government TTCs (14 out of 118) have better infrastructure facilities. However, PTIs are overloaded, having more trainees than their full capacity. On the other hand, the number of trainees in the 14 public TTCs is less than their capacity. The private TTCs attract more students than the public TTCs because of private TTCs' more lenient compliance with the National University's rules and regulations.

5 Data are for only the government teacher training institutes and do not include students who may be enrolled in universities and other private higher education institutes. 
Table A1.11: Bangladesh-Number of Teachers in Teacher Education Institutions, 2010

\begin{tabular}{|c|c|c|c|c|c|c|c|c|c|}
\hline \multirow[b]{2}{*}{$\begin{array}{l}\text { Type of } \\
\text { Institution }\end{array}$} & \multicolumn{3}{|c|}{ Public } & \multicolumn{3}{|c|}{ Private } & \multicolumn{3}{|c|}{ Total } \\
\hline & Total & Females & $\%$ & Total & Females & $\%$ & Total & Females & $\%$ \\
\hline $\begin{array}{l}\text { Primary training } \\
\text { institute }\end{array}$ & 629 & 184 & 29.25 & - & - & - & 629 & 184 & 29.25 \\
\hline $\begin{array}{l}\text { Teacher training } \\
\text { college }\end{array}$ & 360 & 103 & 28.61 & 1,234 & 228 & 18.48 & 1,594 & 331 & 20.77 \\
\hline
\end{tabular}

- = data not available.

Source: Table 5.6. in Bangladesh Bureau of Educational Information and Statistics (BANBEIS). Basic Education Statistics 2012.

Dhaka. http://banbeis.gov.bd/new

Teachers in the public PTIs and TTCs often become demotivated because of lack of a career structure and professional development facilities. These institutions lack proper academic personnel and their staffing pattern is outdated. The curriculum, teaching and learning materials, computers, and laboratory facilities are often developed through and provided by the education projects.

Although government teacher training institutions receive funds to purchase teaching materials, there is no regular supply of teaching materials and other resources. In TTCs, for example, when supplies do come, they are often inadequate and sometimes inappropriate. Government TTCs and government secondary schools sometimes get teaching materials from education projects of the MOE. Private TTCs and private secondary schools, on the other hand, do not have funds to purchase the required teaching materials. Investing in libraries can be an option, but this is feasible only if the TTCs have good libraries or a common resource center. Another problem is that teachers may not have time to use the libraries.

The 14 government and 104 private TTCs are mostly located in and around the capital city of Dhaka and are inaccessible to potential student teachers from other areas, particularly those from the ethnic minorities. The government can either establish TTCs in these areas, taking into consideration the geographic location, ethnicity, and population of the catchment area, or partner with existing higher education institutions to deliver training. A cost-benefit analysis can help make the decision.

\section{Organizational and Management Effectiveness of the Teacher Development System}

There are three types of service providers in the current teacher education system in Bangladesh: a few universities, the TTCs (government and private), and the PTIs (all public). The PTIs and the TTCs are the backbone of the teacher development system for primary and secondary education, respectively. 
PTIs are under the Directorate of Primary Education but not attached or linked to any university in terms of academic guidance and quality monitoring; hence, their academic credibility is in question. Recently, there has been an arrangement with Dhaka University to accredit the new Dip-in-Ed program offered by PTIs.

TTCs, on the other hand, are under dual administration. The 114 government TTCs and the 104 private TTCs are both academically under the National University, but administratively, the government TTCs are under the DSHE and the 104 private TTCs are under the National University's administration. There are three organizations involved in the provision and management of secondary-level teacher education: the general universities, National University, and DSHE. The universities have their own system of management through academic committees, syndicates, senates, or similar bodies. The National University has a faculty (Centre for Post-Graduate Studies, Training and Research) whose dean looks after the management of the 104 private TTCs. The DSHE manages 14 government TTCs through the Office of the Director of Training.

Unlike government TTCs, most private TTCs do not have the minimum facilities required to impart teacher education, mainly due to lack of effective monitoring. To meet the need for trained teachers in the country's secondary schools, the government adopted a policy of allowing the establishment of private TTCs, with affiliation and monitoring authority given to the National University. However, in the absence of proper infrastructure and staff, the National University could not implement the government policy properly. This is one illustration of the gaps between policy formulation and implementation that have resulted in the deterioration of teacher education standards in the country. For proper implementation, policy formulation should be supported by necessary infrastructure and human resource development.

The current requirement for entry into secondary education teaching service is a bachelor's degree (e.g., BA, BSc, or BCom) with or without the professional BEd training before entry. The Nongovernment Teachers Registration and Certification Authority (NTRCA) registers teachers of nongovernment schools, which appears to impose a quality check in the system of recruitment. However, the NTRCA registers teachers with or without a professional degree. This puts the objective and validity of teacher registration under question. The NTRCA Law of 2005 requires private schools to appoint teachers from the registered candidates only. A proposal to resolve this issue is to make BEd training compulsory along with graduation. Teacher recruitment in government schools is centralized and recruitment is done through competitive examinations, enforcing some elements of quality control. The recruitment process is long in both the government and private school systems.

The NEP 2010 also proposed to establish the NTSC for the recruitment of teachers in nongovernment schools and madrasahs. Once this is in place, the NTRCA may be abolished. However, the rules and guidelines for the NTSC should draw from the lessons in the implementation of the NTRCA Law.

As mentioned in Chapter 3, the performance monitoring of teachers is the responsibility of the field-level education officers at the upazila (subdistrict) level. At the school level, the head teacher and the school management committee are supposed to monitor the classroom performance of the teachers. However, teacher performance monitoring lacks 
definite purpose and objectivity and is not linked to incentives. Teachers often do not get feedback from the monitoring. The management information system is still in the development stage and reliability of the statistics remains questionable. Tracking individual teacher performance and professional development is currently not possible.

\section{Quality of Teacher Education and Training Programs and Delivery}

\section{a. Preservice Education and Training}

Preservice training programs for primary and secondary school teachers are of 1-year duration in Bangladesh. Two government TTCs and a few universities offer a 4-year BEd (Honors) program. However, it is not popular since the 4-year honors degree and the 1-year BEd degree get the same weight in employment. In many countries, the duration of preservice training is more than 1 year. Particularly in developed countries, teacher education programs provide students with a longer period of face-to-face practice teaching in the schools. In some programs, students are exposed to supervised teaching in schools for 1 year. The rational move in preservice education in Bangladesh is to amalgamate subject knowledge with pedagogy, which is not possible in a 1-year program. Moreover, the PTIs or TTCs do not have the facilities or ability to teach general subjects like those of university departments.

It will require bold measures from the government to make changes at the policy level to resolve this issue. One option is to adopt a 4-year BEd program and phase out the existing 1-year BEd. The academic staffing pattern will have to change. Subject teachers with pedagogic background will gradually replace teachers with only subject backgrounds. There will also be massive financial implications that can be eased with private sector participation.

As for the nongovernment secondary education teachers, the registration done by the NTRCA is a one-shot process. Once employed in a school within 5 years of registration, a teacher does not need to reregister. There is minimal incentive for professional development among teachers. Hence, the supply of trained teachers falls short of demand. ${ }^{6}$ A reregistration process should be linked to in-service training so that teachers are motivated to pursue continuing professional development. Increasing the number or capacities of TTCs must also be explored. Registration should also be applied to government school teachers as part of national standards.

\section{b. In-Service Teacher Training}

Although there are government PTIs and TTCs for preservice education of primary and secondary teachers, there is no allocation for in-service training within the education budget. In-service education is yet to be institutionalized and is mainly done through different education projects funded by development partners.

For example, in secondary education, projects usually utilize the facilities of the 14 government TTCs and, sometimes, schools with good facilities. However, these inservice training programs lack coordination. (For instance, one teacher may get training from different projects in the same topics, while others receive no training at all.) This also increases unnecessary expenditure and often disrupts academic activities since

\footnotetext{
6 Based on ADB (2012).
} 
some teachers are kept away from the classrooms to receive training outside the schools. This problem can be avoided with a functional and updated database on the training needs profile of the teachers, which may be managed and maintained by the NTEC in coordination with the Directorate of Primary Education and the DSHE. It will readily show who has taken what training and who has received no training yet so to ensure equity among all teachers at all levels.

However, despite having accessed training, teachers often do not use the new knowledge and skills gained, partly because of unchanged mind-sets and partly because large classes (60-100 and more students in a class) are not conducive to the application of new teaching and learning techniques learned from the training courses. Lack of accountability and effective supervision, support, and monitoring mechanisms do not help.

Moreover, there is little financial incentive for untrained teachers to take on the required pedagogical training as the income differential between trained and untrained primary school teachers is marginal. This can be risky, especially when primary school teachers are recruited before being trained. They may never complete the training because the benefit is not sizable. Doing hours of tutoring may be even more financially rewarding. Hence, some teachers may remain untrained and technically unqualified. It should be noted that the income differential between head teachers and teachers is small at primary schools.

To improve the in-service teacher training system in Bangladesh, the following aspects must be considered:

(i) institution of a teacher development policy;

(ii) formulation of a strategic development plan covering both preservice and inservice training, including training centers;

(iii) recognition of in-service training programs as a part of teachers' CPD and linking it to some incentive system; and

(iv) provision for in-service training in the education budget.

\section{Financing Teachers and Their Professional Development}

There is no separate budget for teacher education. The government provides support to the public teacher education institutions only through the budget of the MOE. The government allocation is mainly toward the salary of the teacher and other staff. Teachers and staff get their salary directly from the government exchequer. TTCs do not have budgetary allocations for staff development. They get a lump sum for electricity, water, and other utilities. The fee collected from the students is minimal in the case of the public TTCs. The present budget system does not allow the government teacher education institutions to go for other innovative activities and research. Therefore, the government needs to move away from block grants and adopt performance or results-based financing. The students' fees are the only source of income for the private TTCs.

\section{Information and Communication Technology to Support Teacher Development}

The information and communication technology (ICT) revolution imposes particular challenges for education systems in Bangladesh: (i) participation in the ICT system; (ii) impact of ICT on access, cost-effectiveness, and quality of education; and (iii) the way ICT changes the education process. 
Use of ICT in preservice and in-service teacher education and training is very limited. The TQI-II project provided ICT facilities to 14 government TTCs. The government TTC teachers now can browse the web to find resource materials for use in the classroom. Government TTC students have limited access to internet facilities at the campus to search for their learning materials. Private TTCs usually do not have internet facilities.

The PTIs and the TTCs, through different education projects of MOPME and the MOE, have developed internet facilities in their system. Both the teachers and the students have on-campus limited access to internet facilities. ICT is yet to be integrated into the curricula for preservice teacher education and in-service teacher training.

$\mathrm{BOU}$ is the only university in Bangladesh offering various educational programs through distance education. Established in 1992 by an act of Parliament, it has opened up new vistas in distance education in the country. Situated in Gazipur, about 30 kilometers north of Dhaka, BOU has a printing and production division and a modern media center. BOU's programs are aimed at everyone, particularly working people and women and those socially disadvantaged who dropped out of the school system.

$\mathrm{BOU}$ relies heavily on print materials. Electronic media such as radio, television, audio and video recordings, tutorial services, computer networking, and the internet are also used in the instructional process. The course materials are available on the website. BOU has regional centers and tutorial centers spread throughout the country. All these centers have internet facilities. Facilities for videoconferencing are being installed. The use of these techniques helps BOU take its academic programs to the doorsteps of people far and wide. It makes room for in-house education.

Bangladesh is facing challenges to equip its citizen with the knowledge, skills, and positive attitudes on ICT. Building a strong ICT infrastructure is a prerequisite for making Bangladesh a digital society. For this, the following relevant issues need to be addressed:

(i) Power deficit. The latest statistics reveal that Bangladesh faces a power deficit of up to 2,000 megawatts (MW) against a daily demand of 5,000 MW. Uninterrupted power supply is a must for proper ICT development.

(ii) Network infrastructure. Outside Dhaka, only a few computer network infrastructures have been developed so far. Apart from some educational institutes, observation finds that most of the local area network (LAN) setups are in and around Dhaka. This shows that there is a digital gap in the country.

(iii) Use of internet. The statistics reveal that internet penetration in Bangladesh is only $5.0 \%$ (2012), compared with Pakistan at $15.3 \%$ and India at $11.4 \%$. Internet access must be increased for ICT development. However, ICT is contributing to ever-increasing inequalities in Bangladesh through the so-called "digital divide" that splits Bangladesh between those who are "ICT-literate" and the majority who are not.?

(iv) Submarine cable. Since 2006, Bangladesh has been connected with the worldwide information superhighway through a submarine cable. This single submarine cable frequently faces disruption, however, resulting in slow speeds and low bandwidth.

\footnotetext{
7 See Internet World Stats. Bangladesh.www.internetworldstats.com/asia/bd.htm.
} 
(v) Network readiness. The network readiness index, developed by Harvard University, measures the propensity of countries to exploit the opportunities offered by ICT. The index has three components: the environment for ICT offered by a country or community, the readiness of the community's key stakeholders (individuals, businesses, and governments) to use ICT, and finally the usage of ICT among these stakeholders. Unfortunately, the latest survey (FY2007) revealed that Bangladesh's network readiness index ranking is one of the lowest among Asian countries.

(vi) Use of open-source software. Many countries have started using open-source software in ICT development projects. Unfortunately, in Bangladesh, ICT development domain, the culture of using open-source software has not yet been introduced.

(vii) English literacy rate. The strong correlation between English literacy and ICT development is because English is the lingua franca for ICT. The English literacy rate in Bangladesh is less than in its neighboring countries of India and Pakistan. On the other hand, Bengali has not been used to localize the domain of computing.

\section{G. Conclusion and Recommendations}

\section{Issues and Constraints in the Country's Teacher Professional Development}

Despite recognition and strong emphasis in the NEP 2010 of the crucial role of sufficient number and quality of teachers, teacher education and training in both preservice and in-service stages did not get additional attention in terms of planning and budget allocation. In-service teacher training is often project-based and uncoordinated, resulting in inequitable access and unnecessary disruption of classes. It does not help that there is no reliable database on the training needs and profile of teachers. This boils down to the fact that there is no development policy specific for teacher education and professional development. This task has fallen to the NTEC, which is now under review and assessment for improvement in terms of staffing and capacity.

In formulating a policy framework for teacher education and professional development, there is a need to consider other impending reforms in the country's education system. Among these is the proposed changing of the country's education system from the threetier (primary, secondary, and higher secondary) structure into a two-tier (primary and secondary) structure, as well as the education and training for preschool teachers.

The absence of a clear policy framework for teacher education and training has precluded a solid direction for development planning and programming, as well as sufficient budget allocation necessary to increase the capacity and quality of service delivery among the teacher training institutions. Instructional materials and facilities are not adequate or optimized. There is no definite budget allocation for regular in-service teacher training and the project-based in-service training is not linked to any attractive promotion or incentive system. As salaries are low, teachers often resort to private tutoring to augment income. 
The preparation of teachers before entering the service has been an issue in Bangladesh. The period of professional training is short, only 1 year (C-in-Ed and BEd). However, this is not compulsory to enter into service and can be done after appointment. In addition, secondary education teachers are required to have a graduate degree while primary education teachers only need an HSC. There is a need for a more rational preservice education system that should involve better management and an improved curriculum that integrates academic content and pedagogical education.

And while nongovernment secondary school teachers with or without a professional degree need to be registered at the NTRCA to be hired, no registration is required for government school teachers. A registration system for both government and private school teachers can help uphold standards.

On top of all issues on teacher education and training is the need for rational institutional arrangement and coordination and governance, including supervision and monitoring of teachers' performance. A list of teaching competencies that will serve as teacher performance standards for teachers in Bangladesh has yet to be developed. This will also be the framework by which preservice and in-service education and training will be designed. In the absence of teacher performance standards, there is a lack of a valid and reliable basis for monitoring and evaluation.

A teacher's career path, often known as a career ladder, is important in an attractive employment environment. A profession with a good career path attracts better employees and motivates employees to attain excellence to climb the career ladder. Schoolteachers in Bangladesh have a very limited and restricted career path. Opportunities for career advancement through performance motivate people to improve their performance. A system that links the career path to teacher performance is not in place for schoolteachers in Bangladesh.

A sustainable system for continuing teacher professional development is also lacking. Teachers' in-service training programs are mainly project based. Preservice teacher education curricula need renovation and updating. The curriculum for CPD has yet to be developed. The preservice teacher education institutions are busy supplying professionally qualified teachers to the schools. It will be difficult to establish a system of CPD only through these institutions. There should be physical infrastructure and professional staff dedicated to teachers' professional development. A fund for teacher education and training should be allocated separately under the education budget.

Finally, a more holistic approach to teacher education and training in Bangladesh is necessary. National-level planning should consider all potential training providers, including the universities, and assess the number of students already in the system. It will save the government a lot of money and effort if it can harness this supply of teachers from all the different providers.

\section{Visions for Teacher Development Systems for Bangladesh}

Figure A1.2 presents a model of the Bangladesh teacher education and training system as supported by the recommendations above. The NTEC will function as an umbrella organization looking after all teacher education and training concerns in both primary 
and secondary education in the country. It will work in close collaboration with the two education ministries-MOE and MOPME- and their subordinate organizations (e.g. DSHE, TTCs, Directorate of Primary Education, the National Academy for Primary Education, and PTIs), as well as the universities. The NTEC will develop a teacher professional development system as one of its main tasks.

Teacher development consists of two major parts: (i) preservice education that equips future teachers with the necessary knowledge, skills, and attitudes (teaching competencies); and (ii) in-service training programs that help teachers update their knowledge and skills according to new developments in both content and pedagogy.

\section{Figure A1.2: Bangladesh—Proposed Teachers' Professional Development System}

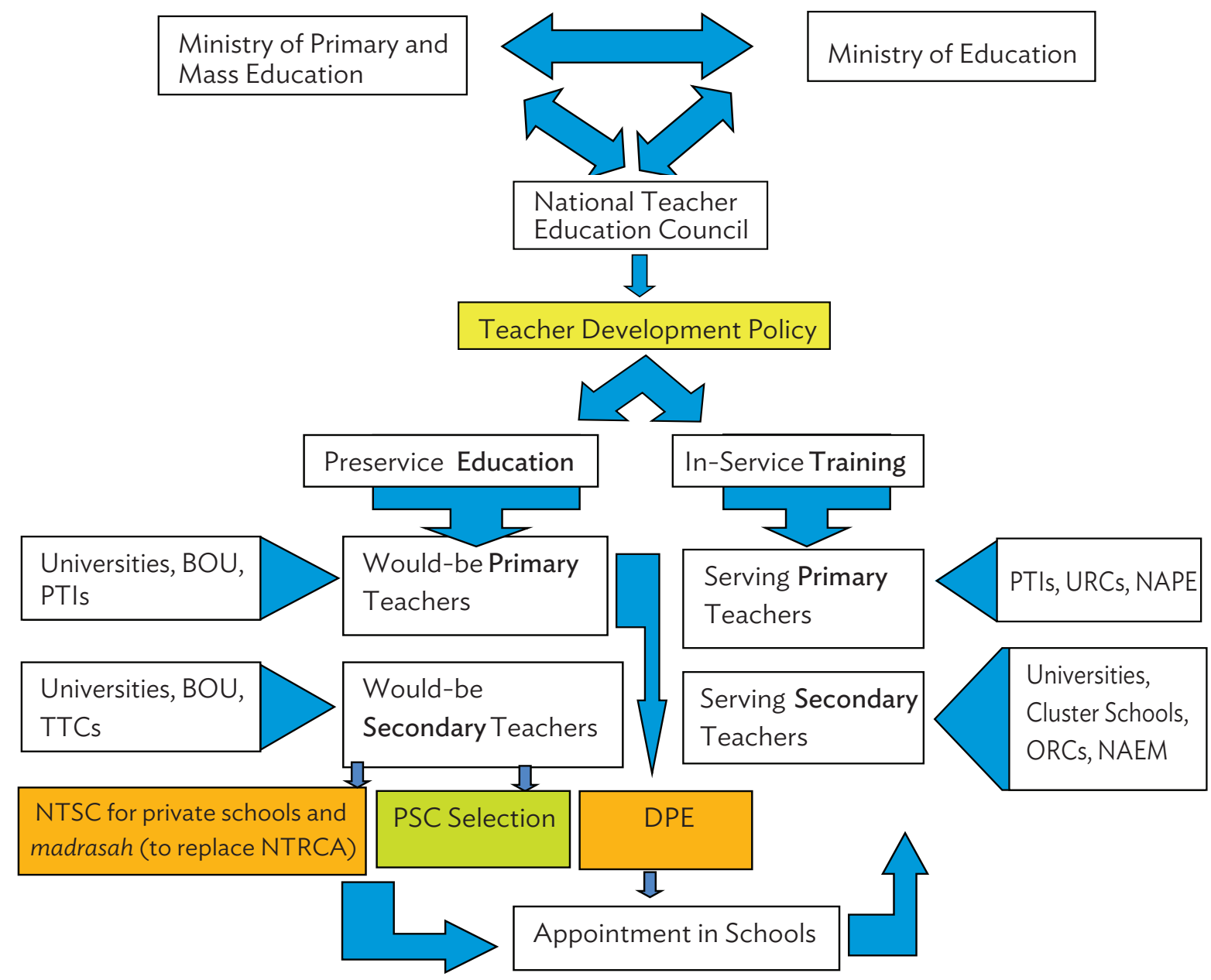

BOU = Bangladesh Open University, DPE = Directorate of Primary Education, NAPE = National Academy for Primary Education, NSTC $=$ Nongovernment Teachers Selection Commission, NTRCA = Nongovernment Teachers' Registration and Certification Authority, PSC = Public Service Commission, PTIs = Primary Teachers Training Institute, TTCs = teacher training college, URCs = Upazila Resource centers.

Source: Author. 
After preservice education, teachers will go through the registration and selection process in the NTSC (to replace the NTRCA), the Public Service Commission, or the Directorate of Primary Education, as the case may be. The NTSC will recruit teachers for nongovernment schools and madrasah primary and secondary teachers.

A few years after joining, teachers will take in-service training courses (following a curriculum for (PD) in different in-service teacher training providers.

Figure A1.3 shows the different aspects of a teacher development policy, components, implementation strategies, and target outcomes. The envisioned Bangladesh teacher development policy will include a fair compensation package, social status, and scope for career and professional development. Preservice education and in-service training should form a major part of the policy. A monitoring and evaluation system in all aspects of teacher development shall be put in place.

It is expected that through implementation of the envisioned teacher development policy, schools and students in Bangladesh will get better teachers.

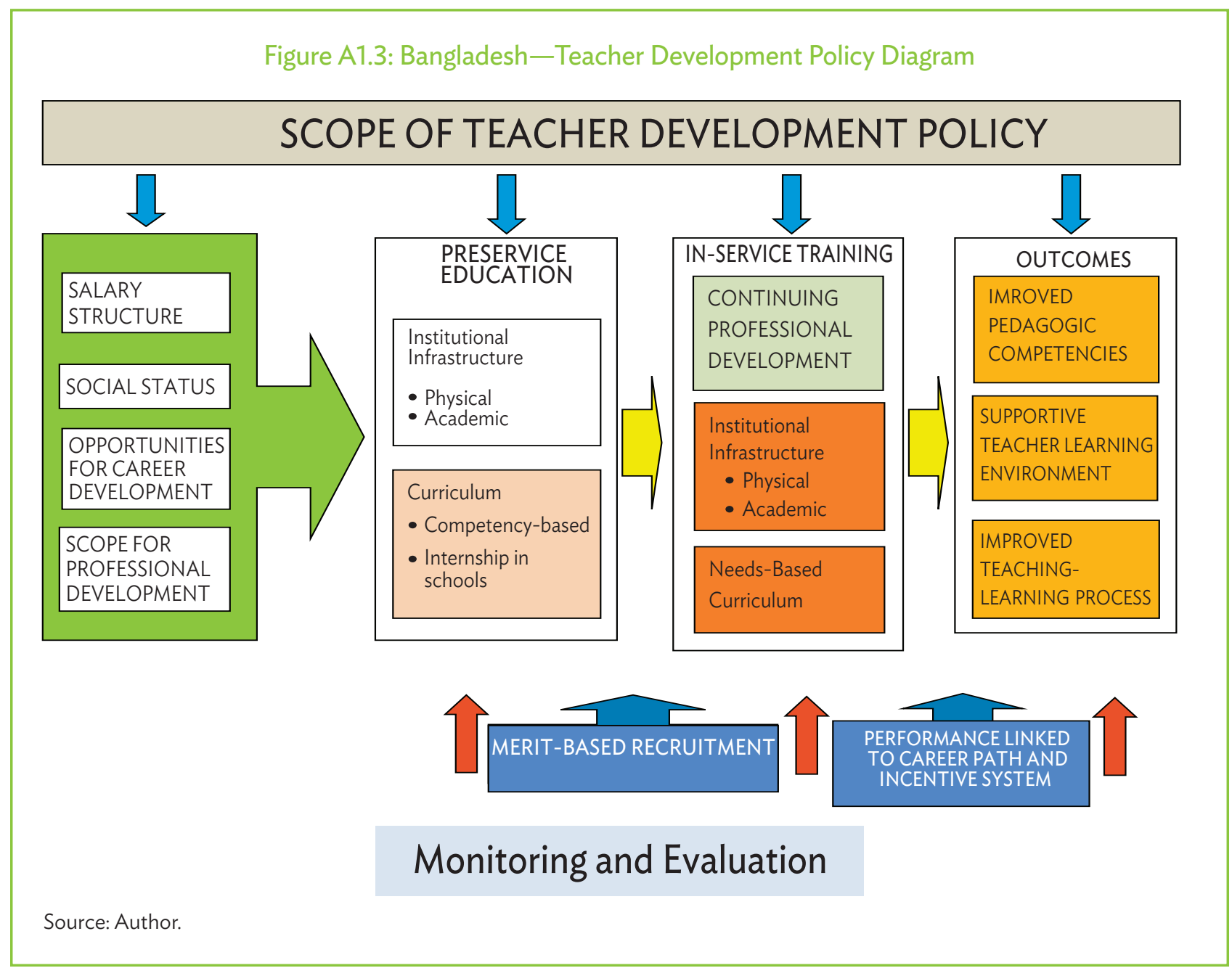




\section{Recommendations}

In the foregoing sections, we have identified the issues and constraints of teacher professional development in the country. The following sections present recommendations to help resolve such issues. Table A1.12 lists these recommendations according to time frame.

(i) Enhance the professional capacity of the National Teacher Education Council. The NTEC should include more professionals. The functions and role of NTEC, as well as its relationships with different entities involved in teacher education and training, should be clearly defined, improved, and implemented.

(ii) Formulate teacher development policy. The NTEC, University Grants Commission, and the MOE, with the participation of teacher educators, should develop the policy. The policy should include guidelines on national teacher and teaching standards and indicators, institutional arrangement and coordination, preservice teacher education, in-service teacher training, monitoring and evaluation system for teacher performance, career path of teachers, recruitment and deployment of teachers, and equivalency across different programs.

(iii) Update teacher education ( $\mathrm{C}$-in-Ed and $\mathrm{BEd}$ ) and training continuing professional development curriculum. The $\mathrm{C}$-in-Ed has been upgraded to Dip-in-Ed but has not produced any graduates or created impact on teacher quality. The program needs to be closely monitored. The National Academy for Primary Education, MOPME, NTEC, and MOE, with the participation of teacher educators from teacher education and training institutions, should develop the new curricula for preservice programs and modules or designs for in-service training. The CPD curriculum should accommodate the concept of recognition of prior learning.

(iv) Build physical and academic infrastructure for a sustainable teachers' continuing professional development system. The existing 54 primary teacher training institutes and 14 government TTCs are not enough for five sustainable CPD services. Some selected private TTCs should be supported to develop capacity to conduct CPD training. NGOs with training infrastructure in different regions (e.g., BRAC) across the country may be engaged and developed as partners to conduct CPD training. Public and private universities should be encouraged and supported by the University Grants Commission to open faculties of education.

(v) Develop a central recruitment and deployment system of teachers. ${ }^{8}$ Teachers for government primary and secondary schools are recruited by the Directorate of Primary Education and the Public Service Commission, respectively. In private schools (primary and secondary), school management committees recruit teachers from those registered by the NTRCA. The NEP 2010 proposed the establishment of the NTSC to recruit teachers for nongovernment schools and madrasahs (primary and secondary). It will replace the NTRCA.

(vi) Formulate a career path for teachers and link it to teacher performance. The NTEC, together with MOPME and MOE, should formulate an attractive career path for teachers that is anchored on performance.

\footnotetext{
8 While the government plans to decentralize the education system, the recruitment and deployment of teachers must be through a central mechanism to ensure standards and equitable distribution of teachers. Recruitment of private school teachers by school management committees was completely decentralized. But this process was marred by issues of nepotism. Hence, a centralized registration system through the NTRCA was introduced. As envisaged by the NEP 2010, however, the NTRCA will be replaced by the proposed NTSC, which will oversee recruitment of teachers for nongovernment schools and madrasahs.
} 


\section{Table A1.12: Bangladesh—Strategies for Teacher Professional Development}

\begin{tabular}{|c|c|c|c|c|}
\hline \multirow[b]{2}{*}{ Strategy/Activity } & \multicolumn{3}{|c|}{ Period of Implementation } & \multirow[b]{2}{*}{ Remarks } \\
\hline & Within 1 Year & $\begin{array}{l}\text { Within } 5 \\
\text { Years }\end{array}$ & In 5-10 Years & \\
\hline $\begin{array}{l}\text { Enhancing functional and } \\
\text { professional capacity of NTEC }\end{array}$ & complete & & & $\begin{array}{l}\text { TQI-II is helping NTEC with } \\
\text { a permanent office and staff }\end{array}$ \\
\hline $\begin{array}{l}\text { Formulation of teacher } \\
\text { development policy }\end{array}$ & complete & & & $\begin{array}{l}\text { MOPME, MOE, and NTEC } \\
\text { in charge }\end{array}$ \\
\hline $\begin{array}{l}\text { Identification of teacher } \\
\text { competencies and teacher } \\
\text { performance standard }\end{array}$ & complete & & & $\begin{array}{l}\text { MOPME, MOE, and NTEC } \\
\text { in charge }\end{array}$ \\
\hline $\begin{array}{l}\text { Review Bachelor of Education } \\
\text { curriculum }\end{array}$ & complete & & & $\begin{array}{l}\text { MOE and NTEC } \\
\text { in charge }\end{array}$ \\
\hline Development of CPD curriculum & continuation & complete & & $\begin{array}{l}\text { MOPME, MOE, and NTEC } \\
\text { in charge }\end{array}$ \\
\hline $\begin{array}{l}\text { Infrastructure development for } \\
\text { CPD (continue) }\end{array}$ & continuation & continuation & complete & $\begin{array}{l}\text { MOPME, MOE, University } \\
\text { Grants Commission, and } \\
\text { NTEC in charge }\end{array}$ \\
\hline $\begin{array}{l}\text { Development of a framework for } \\
\text { recognition of prior learning } \\
\text { (continue) }\end{array}$ & continuation & complete & & $\begin{array}{l}\text { MOPME, MOE, and NTEC } \\
\text { in charge }\end{array}$ \\
\hline $\begin{array}{l}\text { Development of a career ladder } \\
\text { for primary and secondary school } \\
\text { teachers and linking CPD and } \\
\text { recognition of prior learning to } \\
\text { career ladder }\end{array}$ & & complete & & $\begin{array}{l}\text { MOPME, MOE, and NTEC } \\
\text { in charge }\end{array}$ \\
\hline
\end{tabular}

$\mathrm{CPD}=$ continuing professional development, $\mathrm{MOE}=$ Ministry of Education, $\mathrm{MOPME}=$ Ministry of Primary and Mass Education, NTEC = National Teacher Education Council, TQI-II = Second Teaching Quality Improvement in Secondary Education Project.

Source: Compiled by the author. 


\section{References}

Asian Development Bank (ADB). 2010. Second Teaching Quality Improvement in Secondary Education Project, 2010. Manila.

- - . 2011. Teaching Quality Improvement II in Secondary Education Situation Analysis, 2010. Dhaka (TA 7426-BAN). p. 97.

-_- 2012a. Key Indicators for Asia and the Pacific 2012. Manila.

- - 2012b. Policy Advice Technical Assistance: To Develop an Implementation Strategy for the National Education Policy with an Emphasis on the Secondary Sector. Dhaka (TA 7719-BAN).

_- - 2013. Teaching Quality Improvement II in Secondary Education Situation Analysis. Evaluation Report, 2013. Manila.

Bangladesh Bureau of Educational Information and Statistics (BANBEIS). 2011. Basic Education Statistics 2011. Dhaka. http://banbeis.gov.bd/new (accessed September 2012).

- - . 2012. Basic Education Statistics 2012. Dhaka. http://banbeis.gov.bd/new (accessed September 2012). Tables 5.6 and 5.7.

Bangladesh Bureau of Statistics (BBS). 2012. Census of Housing and Population 2011. Dhaka.

Directorate of Primary Education. 2012. Bangladesh Primary Education Annual Sector Performance Report. Third Primary Education Development Program. Dhaka.

Internet World Stats. Bangladesh. www.internetworldstats.com/asia/bd.htm.

Ministry of Planning. 2011. Bangladesh Population and Housing Census 2011: Preliminary Results. Dhaka: Bangladesh Bureau of Statistics.

Nation Master. Average Years of Schooling of Adults: Countries Compared. www. nationmaster.com/graph/edu_ave_yea_of_sch_of_adu-education-averageyears-schooling-adults.

M. Nazmul Huq and M. Sajidul Islam. 2005. Teacher Motivation and Incentives in Bangladesh: A Situation Analysis. Dhaka. http://nazmulhaq.net/pdf/Teacher\%20Motivation\%20 Study\%20report.pdf.

Salary Explorer. Bangladesh. www.salaryexplorer.com/salary-survey.php?id=0-18-1.

World Bank. 2010. World Development Indicators Database: Bangladesh. www.worldbank. org/en/country/bangladesh (accessed September 2012).

- - Global Economic Prospects, Economy and Region Specific Forecasts and Data. http://data.worldbank.org/indicator/NY.GDP.MKTP.KD.ZG/countries/BD$8 s$ ? display=graph.

World Health Organization. Global Health Observatory Data Repository: Bangladesh Statistics Summary. http://apps.who.int/gho/data/?theme=country\&vid=4200 (accessed September 2013). 


\section{APPENDIX 2: TEACHER PROFESSIONAL DEVELOPMENT IN NEPAL}

$\mathrm{N}$ epal's population was around 26.5 million in 2011 (growth rate 1.4\% per annum) (CBS 2011a). In the terai (plain areas) region lives almost half of the country's population, in the hill region $43 \%$, and in the mountain region $7 \%$. Out of the total population, $17 \%$ dwell in the urban areas (taking into account the population of 58 municipalities).

The education sector in Nepal has substantially expanded in recent years. The Interim Constitution of Nepal, 2007 recognizes education as a fundamental right of all citizens and provides free education up to the secondary level. The numbers of schools and student enrollment rates have jumped impressively. At the same time, the literacy rate (for population aged 5 years and above) increased from 54.1\% in 2001 to $65.9 \%$ in 2011 (CBS 2011a).

\section{A. Education System in Nepal}

The seventh amendment of the Education Act, 1971 in 2001 provided the legal framework for the governance and management of basic education in Nepal. School education in Nepal consists of the primary level (grades 1-5), followed by 3 years of lower secondary (grades 6-8), 2 years of secondary (grades 9-10), and 2 years of higher secondary education (grades 11-12). Early childhood development centers and preprimary classes are being introduced with community support, but they are not yet a part of the formal education system. The School Sector Reform Program (2009-2015), which is the existing government program in education guided by the School Sector Reform Plan (2009-2015), has categorized school education into two levels: basic education (grades 1-8) and secondary education (grades 9-12). ${ }^{9}$ Schools in Nepal are categorized into two key types: institutional schools (privately managed schools receiving no government support); and community schools (schools getting government support), which are the largest providers of school education services in Nepal. ${ }^{10}$

\footnotetext{
9 The School Sector Reform Program was implemented during the same time as the School Sector Reform Plan, 2009-2015. The plan was prepared first, then the program.

${ }^{10}$ Community schools are of three types: (i) aided community schools, which are fully supported by the government for teachers'salaries and other operating costs; (ii) community-managed schools, which are also supported by the government, though their management responsibility is transferred to the local communities; and (iii) unaided community schools, which may have partial support or no support at all from the government.
} 


\section{Schools and Students}

There are about 34,361 schools throughout the country (DOE 2012a, 2012b). Over 86\% of primary education students are enrolled in community schools (Table A2.1). ${ }^{11}$ The share of students in secondary community schools slightly decreased over the years: from $86.0 \%$ in 2004 to $83.5 \%$ in 2011. The school-age population (5-14 years or grades 1-10) is around 6.6 million (which is more than $25 \%$ of the total population in Nepal), of which around 7.4 million are in school (up to grade 10), which indicates that nearly all children are present in school (CBS 2011a, DOE 2012a). ${ }^{12}$

\section{Table A2.1: Nepal-Distribution of Schools by Level and Enrollment}

\begin{tabular}{|l|c|c|c|c|c|}
\hline \multirow{2}{*}{ Level } & \multicolumn{2}{|c|}{ Community School } & \multicolumn{2}{c|}{ Institutional School } & \\
\cline { 2 - 6 } & $\begin{array}{c}\text { Number of } \\
\text { Schools }\end{array}$ & $\begin{array}{c}\text { Enrollment and } \\
\text { Share }\end{array}$ & $\begin{array}{c}\text { Number of } \\
\text { Schools }\end{array}$ & $\begin{array}{c}\text { Enrollment and } \\
\text { Share }\end{array}$ & Total \\
\hline Primary (grades 1-5) & 28,898 & $4,111,679(86.0 \%)$ & 4,993 & $671,206(14.0 \%)$ & 33,881 \\
\hline Lower secondary (6-8) & 10,474 & $1,546,647(85.0 \%)$ & 3,317 & $266,033(15.0 \%)$ & 13,791 \\
\hline Secondary (9-10) & 5,539 & $708,154(83.5 \%)$ & 2,399 & $140,416(16.5 \%)$ & 7,938 \\
\hline Higher secondary (11-12) & 2,498 & & 884 & & 3,382 \\
\hline
\end{tabular}

Note: The numbers cited do not yet include religious schools. The number of schools overlap based on services they offer.

Source: Department of Education. 2012. School Level Educational Statistics of Nepal: Consolidated Report 2011 (2068BS). Kathmandu.

According to the 2011 flash report, the net enrollment rate for the primary level (grades 1-5) is $95 \%$; for lower secondary level, $70 \%$; and for secondary, around $52 \% .^{13}$ These figures indicate high dropout and repetition in primary and lower secondary levels (DOE 2012a). From grade 1 to grade 8 , students' promotion rate is around $88.0 \%$, with repetition rate of $5.5 \%$ and dropout rate of $6.5 \%$ (DOE 2012). Student learning achievement has remained poor over the years. A large majority of students fail to complete school education. The pass rate for the School Leaving Certificate examination has remained unpredictable, normally swinging between $30 \%$ and $60 \%$.

\section{Education Financing}

The government's policies and regulations indicate a commitment to financing education. Article 17.2 of the Interim Constitution (2007) has stipulated the provision of free education until secondary level (Ministry of Law and Justice 2007). The Education Act (seventh amendment, 2001) has focused on teacher support, scholarships, and free education for the primary level. While the amount of money invested in the education sector has increased since 2009, the share of the education budget in relation to the national budget has remained almost unchanged (Table A2.2). In fiscal year (FY)2012, the education sector received 63.9 billion Nepalese rupees (NRs), which was around 17\% of the total national budget (MOF 2012a).

\footnotetext{
11 In addition, there are a number of religious schools, which include 674 madrasahs for Muslims, 53 gumbas and vihars for Buddhists, and 39 ashrams and gurukuls for Hindus (DOE 2012a).

12 The number 7.4 million signifies large inflation in enrollment data along with possibility of high gross enrollment rate.

13 The figure contradicts the National Living Standards Survey III, published in 2011, which reported that the actual net enrollment rate observed in the household survey was 69\% (CBS 2011b).
} 


\section{Table A2.2: Nepal-Education Budget, FY2009-FY2011 \\ ('000 Nepalese rupees)}

\begin{tabular}{|l|c|c|c|c|c|c|}
\hline Budget Head & $\begin{array}{c}2008-2009 \\
\text { (actual) }\end{array}$ & $\%$ & $\begin{array}{c}\text { 2009-2010 } \\
\text { Actual } \\
\text { (unaudited) }\end{array}$ & $\%$ & $\begin{array}{c}\text { 2010-2011 } \\
\text { Allocation }\end{array}$ & $\%$ \\
\hline $\begin{array}{l}\text { Gross domestic product at current } \\
\text { price }\end{array}$ & $910,160,000$ & & $1,075,149,000$ & & $1,112,779,215$ & \\
\hline Total national budget & $219,661,918$ & 24.13 & $259,146,064$ & 24.10 & $337,900,000$ & 30.37 \\
\hline Education share of national budget & $35,478,172$ & 16.15 & $46,397,738$ & 17.90 & $57,827,542$ & 17.11 \\
\hline $\begin{array}{l}\text { Share of education budget in gross } \\
\text { domestic product }\end{array}$ & 3.90 & & 4.32 & & 5.20 \\
\hline $\begin{array}{l}\text { Primary education in education } \\
\text { budget }\end{array}$ & $21,551,991$ & 60.75 & $29,348,762$ & 63.25 & $37,008,809$ & 64.00 \\
\hline $\begin{array}{l}\text { Lower secondary and secondary } \\
\text { education budget (grades 6-10) }\end{array}$ & $8,433,392$ & 23.77 & $9,462,816$ & 20.39 & $10,090,528$ & 17.45 \\
\hline
\end{tabular}

Note: Calculation based on 3.5\% gross domestic product growth rate.

Source: Ministry of Finance. Various years. Red Book. Kathmandu.

Out of the total education budget, recurrent expenses on teacher support occupy the major share of the recurrent budget (Table A2.3).

\section{Table A2.3: Nepal-Distribution of Budget Allocations, 2013-2014 ('000 Nepalese rupees)}

\begin{tabular}{|l|c|c|c|}
\hline Budget & $\begin{array}{c}\text { National Center } \\
\text { for Educational } \\
\text { Development }\end{array}$ & $\begin{array}{c}\text { School Teacher } \\
\text { Record Office }\end{array}$ & $\begin{array}{c}\text { Teacher Service } \\
\text { Commission }\end{array}$ \\
\hline Recurrent allocations & 121,129 & 135,4851 & 182,088 \\
\hline Capital & 1,020 & 800 & 180,938 \\
\hline Total & 122,149 & $1,355,651$ & 1,150 \\
\hline
\end{tabular}

Source: Ministry of Finance. 2014. Red Book. Kathmandu.

\section{B. Teacher Development, Recruitment, and Supply}

Around 275,682 teachers currently work in approximately 34,361 schools of Nepal, catering to $7,797,472$ students in grades 1-12. The number of teachers can be further divided into 173,714 for primary level (grades 1-5); 48,848 for lower secondary level (6-8); 35,675 for secondary level (9-10); and 17,445 for higher secondary level (10-12). The majority of the teachers (73\%) are serving in community schools (DOE 2012a, 2012b).

\section{Profile of Teachers}

Equity in teacher workforce. The gender distribution of teachers is still biased toward males, with only $42 \%$ of all teachers in the country being females. This gender gap is larger at the lower secondary (27\%) and secondary (18\%) levels. The proportion of female 
teachers further decreases if only community schools are considered (Table A2.4). Female teachers constitute almost $34 \%$ of all the teachers at the basic level (primary and lower secondary levels, grades 1-8) in community schools. At the secondary level, there are only 14\% female teachers in community schools (Shams, Thapa, and Parajuli 2013). In private schools, the proportion of female teachers for the basic level is $54 \%$, which is higher than their share at the national level. However, the share of female teachers in the institutional secondary schools is only around $24 \%$.

The caste and ethnicity distribution of teachers is also disproportionate to their respective share of the overall population. The participation of Dalits in the teaching workforce is less than $5 \%$ for all levels, although population share is 13\%. The share of Janajatis is higher compared with that of Dalits, but still lower in comparison with their share in the population. There are around 30\% Janajati teachers at the primary level and 18\% at the secondary level.

Geographic distribution of teachers. Around 10\% teachers are currently working in the mountain region, $45 \%$ in the hill region, and $33 \%$ in the terai region (Table A2.4). It should be noted that the mountain region, with $7 \%$ of the population, has $10 \%$ of the teachers and the hill region, with $43 \%$ of the population, has around $45 \%$ teachers, leaving the terai region with only $33 \%$ of available teachers to meet the needs of $50 \%$ of the country's population. There were two main reasons behind the mismatch in teacher distribution. First, teacher distribution was influenced by political decisions and not based on demand and equity. Second, in the hill region, there are fewer students due to the topography, and there are more schools albeit smaller, which requires more teachers per school than in the terai region. Though specific data related to rural and urban distribution of teachers are not available, both schools and teachers tend to have disproportionate concentrations in and around the urban centers. The Kathmandu Valley, the largest urban settlement in Nepal, has around $11 \%$ of teachers. There is a higher tendency for teachers to take posts in urban areas.

Table A2.4: Nepal_Distribution of Teachers by School Level and Geographical Region

\begin{tabular}{|c|c|c|c|c|c|c|c|c|c|c|}
\hline \multirow[b]{2}{*}{ Region } & \multicolumn{3}{|c|}{ Primary } & \multicolumn{3}{|c|}{ Lower Secondary } & \multicolumn{3}{|c|}{ Secondary ${ }^{a}$} & \multirow[b]{2}{*}{ Aggregate } \\
\hline & Female & Male & Total & Female & Male & Total & Female & Male & Total & \\
\hline Mountain & 6,080 & 12,936 & 19,016 & 733 & 3,762 & 4,495 & 254 & 2,548 & 2,802 & 26,313 \\
\hline Hills & 3,230 & 47,638 & 80,868 & 4,506 & 16,297 & 20,803 & 1,943 & 12,499 & 14,442 & 116,113 \\
\hline Valley & 9,652 & 4,893 & 14,545 & 4,358 & 3,735 & 8,093 & 2,553 & 4,301 & 6,854 & 29,492 \\
\hline Terai & 24,421 & 34,864 & 59,285 & 3,639 & 11,818 & 15,457 & 1,521 & 10,056 & 11,577 & 86,319 \\
\hline Total & 73,383 & 100,331 & 173,714 & 13,236 & 35,612 & 48,848 & 6,271 & 29,404 & 35,675 & 258,237 \\
\hline
\end{tabular}

${ }^{a}$ Data are not available for higher secondary levels by region.

Note: Terai means the plain areas in Nepal.

Source: Department of Education. 2012. School Level Educational Statistics of Nepal: Consolidated Report 2011 (2068BS). Kathmandu. 
Teacher positions by quota. Of the 202,594 teachers in community schools, 149,260 are working on approved positions or quota, leaving 53,334 teachers who have been appointed under various makeshift arrangements (Shams, Thapa, and Parajuli 2013). These arrangements include rahat (reliever) teachers (teachers appointed as relief to the school to deal with an immediate teacher shortage); per-child fund teachers (teacher appointed through the per-child funding scheme, which provides funds to finance additional teachers in school); and local source teachers (teachers appointed through a private income source of the school). These local source teachers also need to have a teacher license, and are paid based on additional funds made available by the district education office (DEO) and internal school resources, which are mostly generated through rental of school property, and student fees in some cases.

\section{Teacher Demand and Supply}

The allocation of teacher quotas and selection of teachers follows a separate procedure. The Department of Education (DOE) approves teacher quotas based on demand for quotas requested by the DEO. The demand forecast and quota allocations during 19982014 only involved forecasts for temporary teachers. During 2014, the Teacher Service Commission (TSC) made forecasts for permanent teacher quotas, conducted recruitment, and filled positions. However, it is interesting to note that even though teacher quotas are allocated through the DOE based on the student-teacher ratio (STR) of schools, the teacher supply has remained very much skewed over the years.

Thus, the current system of forecasting demand and supply of teachers is poor and highly politicized. The existing regulations (2004 amendment) provide for the TSC to conduct the teaching license examination. School management committees (SMCs) and DEOs recruit teachers through local advertisement from among the candidates who have obtained teaching licenses. However, the authority to deal with teacher management mostly lies with the DOE, while teacher quota allocations and fulfillment at the school level are observed by both the DOE and the DEOs.

Based on Education Regulations (second amendment, 2002), the standard STR is 50 for terai, 45 for hill, and 40 for the mountain regions. For the primary level, five teachers are allocated to teach five grades where teachers are supposed to teach all subjects in each grade. The provision to have subject-based teachers starts from the lower secondary level (grades 6-9). ${ }^{14}$ Though provisions are clear and specific, the STR varies widely among the regions, as well as the number of approved teacher positions and available teachers. Though there is exactly one teacher position for every 40 primary students, 60 lower secondary students, and 36 students at the secondary level, the region-wide differences indicate that, despite having an adequate number of approved teacher positions for all levels, the supply of teachers is still below the limit in all regions (DOE 2012)..$^{15}$ The STR varies widely, from 17 students per teacher in the Kathmandu Valley to 56 in the terai region at the primary level. This mismanagement is a result of long-term political influence in teacher selection and deployment, until teacher recruitment was localized to the school level.

\footnotetext{
14 These teacher allocation-related provisions are only applicable for community schools approved by the government.

15 Data on approved teacher positions at the higher secondary level are not available.
} 
In general, most of the schools manage to overcome teacher shortage problems by making different adjustments. Such adjustments are made at the school level through temporary arrangements funded by the government or other private or community sources. Through such temporary arrangements, the schools have lowered the STR to 31 from 40 for primary level, to 45 from 60 for lower secondary level, and to 31 from 36 for secondary level. Of the total teachers available in schools, $26 \%$ are arranged through such temporary mechanisms to meet the temporary shortage of teachers created due to distribution problems (DOE 2012a). It must be noted here that schools have also arranged private teachers from their internal sources, which is also one of the reasons for schools to collect fees from students, particularly in schools in middle and far west terai. The DEO and the regional education directorate can transfer a teacher with permission or consent from the SMCs of the respective schools. There is a provision of teacher redeployment based on demand and supply. However, the provision is not fully functional.

\section{Teacher Recruitment}

The teacher recruitment process has observed a number of changes over the years but still is unnecessarily complicated. A lot has to do with the inability to finance all the teachers required for the school system. The impact of the official formal process is still visible in the education system, which is characterized by the existing dual stage process of recruitment. ${ }^{16}$

At present, there are multiple teacher recruitment mechanisms depending on types of school and types of teachers (Table A2.5). The recruitment of permanent teachers in community schools and community-managed schools has not been possible due to confusion about existing policy.

Table A2.5: Nepal-Teacher Recruitment Authorities by Type of School

\begin{tabular}{|l|c|c|l|}
\hline Type of School & $\begin{array}{c}\text { Recruitment } \\
\text { Authority for } \\
\text { Permanent } \\
\text { Teachers }\end{array}$ & $\begin{array}{c}\text { Recruitment } \\
\text { Authority for } \\
\text { Temporary } \\
\text { Teachers }\end{array}$ & $\begin{array}{c}\text { Basic Conditions } \\
\text { to Fulfill }\end{array}$ \\
\hline Community schools & TSC & SMC & Teacher license \\
\hline Community-managed schools & SMC & SMC & Teacher license \\
\hline Institutional schools & SMC & SMC & Teacher license \\
\hline
\end{tabular}

SMC = school management committee, TSC = Teacher Service Commission .

Source: Author.

${ }_{16}$ Before 1971, schoolteachers were recruited by school management committees. After 1971, schoolteachers were recruited by a district-level teacher selection committee. Very few teachers were recruited during the 1980s. In 1990, when the Ministry of Education and Sports advertised for about 14,000 teacher positions to apply for competitive written examination, about 200,000 candidates applied. Against the existing regulation to declare only a third more than the available position as eligible candidates for interview, anyone securing 35 marks was declared eligible for interview in the final selection process. About 86,000 candidates were declared eligible for interview for about 14,000 posts. Fearing the possible manipulation in the interview, teacher unions vehemently opposed the results of written examinations. District-level teacher selection committees could not organize "Interview" sessions for final selection. Finally, the government decided to institute a more credible system and declared a new system of teacher recruitment in 1999. The Education Act (seventh amendment, 2001) now provides two types of recruitment systems for the schools of Nepal. 
Recruitment through the Teacher Service Commission. The TSC is a body authorized to recruit permanent government teachers (teaching cadres) based on the Teacher Service Commission Regulation of 2000 as amended in 2009. At present, the TSC is responsible for three key functions related to community school teachers: (i) issue teaching licenses to teachers based on their competency test; (ii) advertise, conduct examinations, and recommend DEOs to recruit teachers for approved government quotas (especially permanent teachers); and (iii) promote permanent teachers to higher levels (third class, second class, first class).

The TSC is authorized simply to follow the recruitment process whereas the responsibility to forecast demand and depute teachers lies with the DOE and SMCs. So far, the teacher recruitment examination has been conducted only twice by the TSC. The first time was at the beginning of the 1990s and the second about 2 decades later in May 2013. The implementation of the policy related to the TSC is problematic since the regular demand forecasting, teacher recruitment, and deployment process has remained dysfunctional for a long period. Both recruitment examinations conducted so far witnessed huge numbers of applicants, many of them teachers already serving on a temporary basis.

Recruitment through school management committees. The teacher recruitment process is also partly decentralized. After the latest amendment to the Education Act, the responsibility for recruiting teachers was completely transferred to the SMCs. The SMCs are required to follow a standard procedure of teacher recruitment where only teachers with a teaching license can be recruited. Teacher recruitment through SMCs is not transparent, and most SMCs tend to recruit teachers who are close to them. ${ }^{17}$ Despite the stigma of politicization, the recruitment process at the local level has ensured timely supply of temporary teachers in schools and has also made SMCs responsible in ensuring availability of teachers. If the recruitment process of temporary teachers was to be made through the TSC, given its experience of teacher recruitment over the years, the process could have been lengthy, leading to teacher shortages in schools for longer periods of time.

Teacher recruitment in private and institutional schools. In the case of private schools, the role of the TSC is limited to the issuance of the teaching license. The Ministry of Education (MOE) has recently (in 2013) issued guidelines with an objective to establish standard procedures of teacher recruitment in private schools. The guidelines make it mandatory for private schools to recruit teachers from among those who have adequate academic qualifications, have acquired a teaching license, and have received preservice teacher training. Furthermore, the guidelines state that private schools should have a teacher selection committee also involving government officials - the school supervisor. ${ }^{18}$ Still, most private schools have not yet considered making it mandatory for teachers to obtain a teaching license. Private schools have developed their own process of appointment, though they are also required to follow a formal procedure.

\section{Conditions of Employment}

The Education Act (seventh amendment, 2001) guides the overall education system, including teacher management, which is substantiated by the Education Regulations and the Teacher Service Commission Regulations. The legislation further guides the

\footnotetext{
17 Based on discussions with teachers, head teachers, and preservice students.

18 The school supervisor is a position within the district education office and is supposed to monitor the performance of schools and teachers.
} 
recruitment, placement, and transfer of teachers, including the provision of teacher unions for the professional development of teachers. The Education Act (amendment based on ordinance, 2004), Clause 4.20 stipulates specific functions and duties for teachers (job description) regardless of their level or area of teaching and qualifications. A teacher is primarily supposed to complete teaching as per the curriculum within the specified education calendar, evaluate the learning achievement of children, and build rapport with parents regarding student performance.

Salaries and benefits. There is a defined salary scale for teachers, which is indexed to the salary of other government officials. The salary scale varies by level (primary, lower secondary, secondary) but not by type of subject taught and performance of teachers. Since a teacher's salary is also made comparable to that of other civil servants, the scale is determined by the Ministry of General Administration and the Ministry of Finance depending on the national price index..$^{19}$ Teachers are entitled to all civil service benefits. ${ }^{20}$ Table A2.6 shows the salary scale for teachers in Nepal.

Table A2.6: Nepal—Monthly Salary Scale for Government Teachers

\begin{tabular}{|l|c|c|c|}
\hline Class & $\begin{array}{c}\text { Primary } \\
\text { (grades 1-5) }\end{array}$ & $\begin{array}{c}\text { Lower Secondary } \\
\text { (grades 6-8) }\end{array}$ & $\begin{array}{c}\text { Secondary } \\
\text { (grades 9-10) }\end{array}$ \\
\hline Class I & $18,790(\$ 235)$ & $21,080(\$ 264)$ & $24,740(\$ 309)$ \\
\hline Class II & $14,480(\$ 181)$ & $18,790(\$ 235)$ & $21,080(\$ 264)$ \\
\hline Class III & $13,560(\$ 170)$ & $14,480(\$ 181)$ & $18,790(\$ 235)$ \\
\hline
\end{tabular}

In Nepal, the annual salary of teachers (minimum of $\$ 2,000$ per year) is almost three times the national per capita income of around $\$ 700$. The teacher salary scale in Nepal is also higher compared with that of teachers in Bangladesh and Pakistan, but much lower compared with that of teachers in India and international practices (Shams, Thapa, and Parajuli 2013). There is also a general understanding among teachers that the salary they receive is inadequate considering the local market prices and aspirations. It is further confounded by the regular delays in salary disbursement. In a typical scenario, teachers must wait around 4 months to receive their salary, and sometimes it takes even longer. This delay is exclusive for teachers, since the civil servants working within the MOE, including those working at the district level, receive their salary at the end of every month.

19 In July 2011, the government increased the existing pay scale of all the government employees by up to $42.9 \%$ considering the current rate of inflation. As of March 2013, a schoolteacher in Nepal will get at least \$2,210 per year as a salary. The salary scale differs by level and class.

20 The Education Regulation has made clear provisions on all types of benefits for permanent and temporary government teachers. Major benefits enjoyed by the permanent teachers recruited through the TSC are (i) a 13-month salary per year (for around 10 months of work), (ii) $10 \%$ addition to be deposited in a service fund, (iii) pension after serving 20 years (the spouse receives $50 \%$ of the pension in case of death of the retired employee), (iv) gratuity if a person has served more than 5 years and less than 20 years, ( $v$ ) fixed amount of medical fund, (vi) monetary subsidy of accumulated home and sick leave, and (vii) health insurance (in the form of lifetime medical coverage) (Shrestha 2008; Shams, Thapa, and Parajuli 2013). In addition, they are also entitled to various types of leave, including (i) casual leave of 6 days in a year; (ii) 6 days festival leave; (iii) 12 days sickness leave; (iv) up to 60 days maternity leave before or after childbirth; (v) up to 15 days obsequies leave in case of death of one's father or mother; (vi) extraordinary leave not exceeding 1 year at a time, and 3 years during the whole period of service; and (viii) study leave of up to 3 years at a time or in parts. 
The disbursement of teacher salary is a long process since it requires transfer of funds from the DOE to the school accounts through the DEOs. The low purchasing power of the salary and the delayed payment contribute to low teacher morale and lack of motivation to improve performance.

There are no specific benefits for temporary teachers including rahat teachers who receive a salary equal to class III standards of their level. In terms of benefits, they receive salaries for 13 months and are entitled to sick leave based on provisions. Rahat teachers, however, are not entitled to sick leave, although in principle, their employment conditions are to be decided by the SMC. The work conditions for per-child funding teachers is still not clear since their salary depends on the funds available with the schools based on the number of students. The per-student amount available to schools on the part of the per-child fund is NRs2,000 per year though it has been found to range between NRs1,600 and NRs2,000 for different geographic regions (DOE 2007). Per-child fund teachers are largely underpaid. For higher secondary teachers, the government recently started providing a total of NRs21,080 per month to approved government higher secondary schools as a grant to finance two teachers. Some schools in remote districts and schools operating science streams are provided with the amount for three teachers. This, however, is not a teacher quota as being demanded by higher secondary teachers.

The demand, supply, and workload for teachers tend to vary by levels and subjects, and there is no difference in salary for teachers of the same level and class regardless of the subject they teach, their workload, and their level of performance. As there are no incentives for improvement, teachers have reported that such a uniform payment structure (regardless of job description and performance) discourages them to perform effectively and leads to decreased performance as they increase in service years.

Promotion system. Since 1971, teacher positions have been equated with the civil service positions in government, and teachers have started earning salaries equivalent to the civil service positions (Shrestha 2008). The existing career path allows a third-class primary teacher (new entrant to primary level in permanent government quota) to become a firstclass secondary teacher through open competition and/or internal promotion (Table A2.7). There are provisions for both horizontal and vertical promotion pathways.

Employment condition of head teacher. Although head teachers are expected to carry out management functions along with or without their teaching duties depending on number of teachers available in schools, for which they are provided only a small additional allowance, they are no different from teachers in the overall school setting in Nepal. They are selected from among the teachers and also need to take some classes depending on the number of teachers available in the school. The SMC, with approval from the DEO, has the authority to select the head teacher from among the teachers. The head teacher, by virtue of the position, has to act as the member-secretary of the SMC, and as such has a number of powers delegated in terms of day-to-day administration and overall instructional management of the school. The long list of activities assigned to the head teachers is not in line with the limited authority and incentives they receive (Box A2.1). 
Table A2.7: Nepal-Teacher Promotion Pathways

\begin{tabular}{|l|l|l|l|}
\hline $\begin{array}{l}\text { Promotion } \\
\text { Pathways }\end{array}$ & $\begin{array}{l}\text { Horizontal Promotion } \\
\text { Pathways }\end{array}$ & \multicolumn{1}{|c|}{$\begin{array}{c}\text { Vertical Promotion } \\
\text { Pathways }\end{array}$} & \multicolumn{1}{|c|}{$\begin{array}{c}\text { Cross-cutting } \\
\text { Opportunities }\end{array}$} \\
\hline Levels & $\begin{array}{l}\text { First class } \\
\text { Second class } \\
\text { Third class }\end{array}$ & $\begin{array}{l}\text { Secondary } \\
\text { Lower secondary } \\
\text { Primary }\end{array}$ & $\begin{array}{l}\text { Head teacher } \\
\text { Resource person } \\
\text { Teacher trainer }\end{array}$ \\
\hline $\begin{array}{l}\text { Basis of } \\
\text { promotion }\end{array}$ & $\begin{array}{l}\text { Years of service } \\
\text { Performance monitoring } \\
\text { Training }\end{array}$ & $\begin{array}{l}\text { Academic qualification } \\
\text { Competency }\end{array}$ & $\begin{array}{l}\text { Referrals (ad hoc basis) } \\
\text { Years of service also } \\
\text { counts }\end{array}$ \\
\hline Procedure & $\begin{array}{l}\text { This is a regular } \\
\text { promotion mechanism } \\
\text { whereby teachers are } \\
\text { promoted by the TSC } \\
\text { on a periodic basis. }\end{array}$ & $\begin{array}{l}\text { Teachers apply for } \\
\text { available positions } \\
\text { with the TSC or } \\
\text { SMC. Teachers are } \\
\text { selected through open } \\
\text { competition that is } \\
\text { similar to taking up a } \\
\text { new job. Years of service } \\
\text { are a plus factor. }\end{array}$ & $\begin{array}{l}\text { Teachers are nominated } \\
\text { by the district education } \\
\text { office or a group of } \\
\text { teachers, SMC, or other } \\
\text { body. Nomination is } \\
\text { basically deputation. }\end{array}$ \\
\hline Chances of \\
promotion
\end{tabular}

SMC = school management committee, TSC = Teacher Service Commission.

Source: Compiled by the author.

\section{Box A2.1: Nepal-Roles and Responsibilities of Head Teachers and Teachers}

\section{Head Teachers}

The Education Regulations have provided a long list of the major roles, responsibilities, and functions of a school head teacher as follows:

- maintain academic environment, academic quality, and discipline;

- create an environment of mutual cooperation through coordination among teachers and other staff, students, and guardians;

- prepare programs for running classes in the school in consultation with teachers, and supervise them as per the regulations;

- make or cause to make provision for sanitary and other extracurricular activities in the school;

- operate administrative functions of the school;

- admit students in school and conduct examinations;

- give transfer certificates and other certificates to students as and when required; 
- recommend to the school management committee departmental actions including dismissal from service of any nonperforming teacher or employee appointed by the school on its own resources who does not abide by rules;

- recommend appropriate rewards and punishments for teachers to the management committee and district education office;

- hold teachers' meetings at least once a month, conduct discussions on school-related subjects, and maintain records of such meetings and discussions;

- expel from the school any student violating discipline;

- implement the government-prescribed curriculum and textbooks in the school;

- spend budgets as per the direction and authority entrusted to him or her and maintain accounts of income and expenditure;

- prescribe functions and duties of the teachers and other employees working under him or her; and

- send details and statistics relating to academic progress of the school, as certified by the concerned supervisor, in the format and within the time prescribed by the ministry.

\section{Teachers}

The Education Regulations have provided a long list of the major roles, responsibilities, and functions of schoolteachers as follows:

- regularly attend and remain in the school in the specified time;

- complete the teaching as per the curriculum within the specified educational calendar;

- evaluate the capacity of each child to learn and read, and give necessary guidance to motivate the student toward learning and reading;

- motivate the guardians of children to get their children admitted to the schools to ensure the right of each child to obtain free and compulsory basic education;

- hold regular meetings and discussions with guardians or children, as required, to enhance the competency and capacity of children to learn;

- make the children and their guardians or communities aware of the right of all children to obtain free and compulsory basic education;

- carry out activities as required to succeed in the programs adopted by the Government of Nepal on the alleviation of illiteracy and free and compulsory basic education; and

- perform, or cause to be performed, other functions as prescribed.

Source: Compiled by the author.

\section{Teacher Quality Assurance}

This section discusses minimum quality standards and quality monitoring along with institutional organizational arrangements.

\section{Minimum Quality Standards and Quality Monitoring}

Availability of quality standards. Although a formal quality assurance of teachers and teacher quality standards is not available, there are some set competency standards desired for teachers. There are entry qualifications for teachers, which include (i) academic qualification; (ii) marks or grades earned while obtaining those academic qualificationsthough the quality of this knowledge and skills acquired through these qualification is often not reviewed; (iii) marks or grades obtained during TSC examinations; and (iv) communication skills, the grading of which is based on interviews. The Education Regulations and TSC guidelines specify basic competency requirements for teachers. 
In 2009, the School Sector Reform Plan updated the entry qualification requirements for schoolteachers. According to the latest provision, a teacher is required to have passed grade 12 to become a teacher for the basic level (up to grade 8), a bachelor's degree for secondary level (up to grade 10), and a master's degree for higher secondary level (up to grade 12). In addition, a teacher is also required to have passed a "teacher license" examination prior to applying for any teacher post.

Competency assessment. The competency assessment by the TSC, which is more about making decisions about promotions than ensuring minimum quality standards, follows a competitive and systematic procedure. Teachers and prospective teachers perceive that the assessment process does not measure all essential competencies and the teacher selection process depends largely on theoretical knowledge rather than on an individual's characteristics and ability to teach. The teaching license examinations run by the TSC are based mostly on theoretical knowledge obtained during preservice teacher training. These examinations usually do not adequately assess the competence of teachers in line with the curriculum of the subject or level they want to teach. ${ }^{21}$ Moreover, the lack of assessment of real classroom performance of teachers further weakens the competency assessment procedure, though such examinations are already part of preservice training programs. ${ }^{22}$ The competency standards, though enforced, have not been recently updated based on upcoming shifts. For example, the existing competency assessment does not include information and communication technology (ICT)-related competency, competency related to multilingual and mother tongue teaching, and competency to teach in English.

Competency of existing teachers and teacher performance monitoring. Only around 46\% of the current teachers in basic education meet the upgraded qualification requirements set by the School Sector Reform Plan. A large majority of teachers currently under the teaching service were recruited prior to the provision of teaching license requirements. Though there are set competency requirements and various policy documents to secure desirable student outcomes as a mechanism for teacher quality assessment, the available monitoring mechanism, apart from being not specific and systematic, is also not functional. The existing mechanism does not monitor individual teacher performance. There is a general provision of regular monitoring and scoring by head teachers and school supervisors. However, the head teachers are not trained to monitor teacher performance and are recruited initially as teachers; and school supervisors are based in the DEOs and seldom travel to schools. Even if they conduct monitoring in some instances, the procedure is not systematic enough and does not monitor the quality standards. The reward and sanctions system is also not in practice, which turns the monitoring simply into a routine ritual activity. Teachers are normally provided with full marks without making any distinction on the quality of their performance. ${ }^{23}$

The reform initiatives in recent years have introduced a mandatory provision of social audits in schools as a process to evaluate the performance of schools every year through parental participation. Social audits involve discussion about teacher performance and constitute valid mechanisms to assess performance of the team of teachers as a whole

\footnotetext{
21 Reported during discussions with teacher trainers in Kavre and Sunsari districts.

22 Reported by preservice students in Sunsari district.

${ }^{23}$ Reported during discussion with teachers.
} 
from the perspective of parents, but they are not practiced the way they should be and focus largely on the audit of financial (income and expenditure) aspects.

The process to review and update teacher competencies also has not been in place despite the introduction or upgrading of new competency levels for teachers in recent years. For example, the introduction of a teacher license as a new competency requirement became useless for serving permanent teachers since they were exempted from the teacher license exam. On the other hand, the efforts made through the School Sector Reform Plan to raise teacher qualification levels have so far not been implemented in full for various reasons. Clearly, a comprehensive system to ensure competency and quality standards consistently among teachers is not available.

\section{Institutional and Organizational Arrangements for Quality Monitoring}

Quality monitoring arrangements. There are agencies, interest groups, and individuals who are expected to be involved in monitoring teacher quality standards and quality outcomes. Despite the role of various agencies and processes, the quality of teachers is still very poor (Table A2.8). There seems to be an overemphasis on administrative and career matters rather than on quality of professional practice. The primary role of the ministry is to establish policy and institutional measures. The TSC is responsible for ensuring teachers meet the entry requirements. In the absence of any specific "teacher standards board" as such, the TSC endeavors to look after overall quality improvement and quality assessment, promotion, and related affairs. The quality assurance system is still traditional and thus will require improvements for effective implementation. ${ }^{24}$ The TSC also looks after the teacher recruitment and promotion mechanism, whereas the School Teacher Record Office (STRO) keeps records related to community school teachers (only the permanent government-funded teachers). The STRO basically determines the terms and conditions of the teaching service for the provisions of pension, gratuity, insurance, medical, and other benefits as mentioned in the Education Regulations of the MOE. The office has a very low profile within the MOE and faces a staff shortage and resource crunch. The office has not yet been able to build a comprehensive teacher management information system (TMIS) despite its mandate. In this context, it is interesting to note that the STRO does not have any record that could enable monitoring of teacher performance, or that could be used for rewarding or sanctioning teachers. At the school level, the SMC and head teacher are also responsible for monitoring teacher performance. Nevertheless, monitoring at the local level has remained mostly irregular and unsystematic.

Competency and quality assurance in institutional schools. The government has made teacher competency standards, such as teacher license and minimum academic qualification requirements, mandatory for all teachers of community schools and institutional schools. Unfortunately, these provisions are not strictly enforced in many institutional schools. However, the private schools have attempted to enforce some ad hoc mechanisms, the strength and use of which differ by type and size of the school. Normally,

\footnotetext{
24 Previously, provisions of assessment linked with teacher training were in place, but they are not functional at present particularly because the long-term in-service training has been replaced by the short demand-based training program. Under earlier arrangements, teacher trainers provided scores to trainees based on their performance, which were useful to determine teacher competency.
} 


\section{Table A2.8: Nepal—Expected Roles of Different Agencies, Interest Groups, and Individuals in Quality Monitoring}

\begin{tabular}{|c|c|c|}
\hline $\begin{array}{l}\text { Agencies/Interest } \\
\text { Groups/Individuals }\end{array}$ & $\begin{array}{l}\text { Expected Roles in Quality } \\
\text { Monitoring }\end{array}$ & Remarks \\
\hline $\begin{array}{l}\text { Ministry of Education } \\
\text { (Department of } \\
\text { Education) }\end{array}$ & $\begin{array}{l}\text { Set competency standards, } \\
\text { e.g., qualifications, experience, } \\
\text { knowledge, skills, attitudes. }\end{array}$ & $\begin{array}{l}\text { Latest change in standards was } \\
\text { introduced in } 2009 \text { with the } \\
\text { implementation of the School } \\
\text { Sector Reform Program. }\end{array}$ \\
\hline $\begin{array}{l}\text { Teacher Service } \\
\text { Commission }\end{array}$ & $\begin{array}{l}\text { Administer competency tests } \\
\text { based on set quality standards } \\
\text { during the recruitment process; } \\
\text { issue teacher licenses; promote } \\
\text { teachers based on the results of } \\
\text { performance monitoring. }\end{array}$ & $\begin{array}{l}\text { Competency tests and license } \\
\text { issuance are carried out; quality- } \\
\text { monitoring-based promotion } \\
\text { process is not functional. }\end{array}$ \\
\hline $\begin{array}{l}\text { School Teacher Record } \\
\text { Office }\end{array}$ & $\begin{array}{l}\text { Keep records of teachers } \\
\text { including their performance } \\
\text { against quality standards. }\end{array}$ & $\begin{array}{l}\text { Record keeping of performance } \\
\text { data is not functional. }\end{array}$ \\
\hline $\begin{array}{l}\text { District education office; } \\
\text { school supervisor }\end{array}$ & $\begin{array}{l}\text { Visit schools and conduct } \\
\text { performance monitoring } \\
\text { of teachers through class } \\
\text { observation and other activities; } \\
\text { initiate the incentive mechanism } \\
\text { (punishment or rewards). }\end{array}$ & $\begin{array}{l}\text { The mechanism is completely } \\
\text { nonfunctional. }\end{array}$ \\
\hline Resource person & $\begin{array}{l}\text { Monitor teacher performance } \\
\text { against quality standards; } \\
\text { provide direct technical support } \\
\text { to teachers to enhance their } \\
\text { quality; grade teachers for their } \\
\text { promotion. }\end{array}$ & $\begin{array}{l}\text { Partially functional in terms of } \\
\text { school visit; no record keeping. }\end{array}$ \\
\hline $\begin{array}{l}\text { School management } \\
\text { committee }\end{array}$ & $\begin{array}{l}\text { Monitor basic performance of } \\
\text { teachers such as attendance, } \\
\text { student outcomes, etc.; take } \\
\text { decisions related to their } \\
\text { recruitment, transfers, and } \\
\text { promotions. }\end{array}$ & $\begin{array}{l}\text { Partially functional (where school } \\
\text { management committee is } \\
\text { active). }\end{array}$ \\
\hline Head teacher & $\begin{array}{l}\text { Monitor the performance of } \\
\text { teachers; grade teachers for } \\
\text { their promotion based on their } \\
\text { performance. }\end{array}$ & $\begin{array}{l}\text { Partially functional since teachers } \\
\text { are graded for promotion, } \\
\text { but usually not based on } \\
\text { performance monitoring. }\end{array}$ \\
\hline Teacher unions & $\begin{array}{l}\text { Maintain professional ethics; } \\
\text { ensure quality teacher } \\
\text { performance. }\end{array}$ & $\begin{array}{l}\text { Teacher unions have negative } \\
\text { implications on teacher } \\
\text { performance. }\end{array}$ \\
\hline Student unions & $\begin{array}{l}\text { Act as a pressure group in } \\
\text { enforcing teacher performance } \\
\text { monitoring arrangements. }\end{array}$ & $\begin{array}{l}\text { Student unions are mostly active } \\
\text { for higher education; not focused } \\
\text { on teacher performance. }\end{array}$ \\
\hline
\end{tabular}

Source: National Center for Educational Development. www.nced.gov.np. 
the head teacher, principal, or school manager is responsible for quality assurance and monitoring. ${ }^{25}$

Student assessments as a large-scale teacher quality assurance mechanism. National assessment studies have been commissioned by the MOE at different times in the past using learning achievement tests on a sample of students studying in specific grades of the selected schools. Such studies conducted in selected school subjects generate mean test scores that are no different from scores obtained in school exams. Being low in quality, test scores of these studies could not be compared with test scores obtained from other standardized tests such as the Programme for International Student Assessment or Trends in International Mathematics and Science Study. However, the most important point in this context is that the results of these studies have so far been explained without appropriate understanding whatsoever of their implications on teacher performance monitoring. Therefore, with this perspective of national assessment system gaining ground in recent years (i.e., the $\mathrm{MOE}$, through the School Sector Reform Plan, has recently set up the Education Review Office that conducts a national assessment of student achievement tests on regular basis), systematic monitoring of learning achievement scores should be accompanied by a dependable mechanism for quality assurance monitoring of teacher performance.

Teacher unions in teacher performance management. Teacher unions are critical stakeholders in teacher performance development in Nepal. The Education Act has made mandatory provision for the formation of teacher unions for professional development of teachers. However, teacher unions are playing a very limited role in teacher performance monitoring. Teacher unions are fragmented by political parties and are more concerned about safeguarding teachers' rights as employees. Despite the possibility that they could play a strong role in quality assurance, they have rather resisted efforts to standardize competency requirements among teachers. ${ }^{26}$

Enhancing the competencies to meet quality standards. Currently, there is no comprehensive framework for teacher quality assurance. Considering the need for revising and aligning teacher competencies to meet contemporary practices and quality standards, the existing provisions of both preservice and in-service teacher training programs are not monitored and left open to interpretation by the training providers. The National Center for Educational Development (NCED), an agency responsible for overall capacity development of the educational staff, also operates teacher training institutions to deliver in-service teacher and education management training programs of various levels. However, as this performance monitoring mechanism is not functioning as expected, the competency enhancement activities conducted through NCED have had very little positive effect among the participants, who are not only large in numbers but whose learning is severely limited by an acute resource crunch.

25 The private sector providers have an association known as Private and Boarding Schools Organization of Nepal that also looks after various aspects of monitoring including quality assurance. While quality assurance through the conduct of joint external examinations has since long been in place, standard guidelines to enhance the intrinsic reliability of this mechanism is lacking.

${ }^{26}$ Reported by teachers during focus group discussions in Sunsari district. 


\section{Provision of Teacher Education and Training}

\section{Teacher Training Provisions and Policies}

The Education Regulations (second amendment, 2004) have made NCED responsible for professional development in the education sector. Under the School Sector Reform Plan, the Government of Nepal has made completion of a professional teacher training course (preservice training) mandatory prior to entering the teaching profession (MOE 2009). The School Sector Reform Plan (2009-2015) has made the government responsible for teacher development, and has also stated minimum requirements in terms of the number of teachers. To keep abreast of new developments in teaching and learning practices, teachers must acquire 1 month of professional development training at least once every 5 years (MOE 2009) - which, if not driven by demand, will be concerned more about time served rather than enhanced capacity. The School Sector Reform Plan has acknowledged NCED as an agency responsible for overall teacher performance development activities including development and organization of training. However, the approach to provision of professional development training programs remains supply-driven instead of needs-based. It anticipates that NCED will conduct recurrent training courses for primary and secondary teachers through the education training centers (ETCs).

Teacher training has been a priority area in basic education (grades 1-8) in Nepal. As such, progress in terms of the proportion of trained teachers has also been improved as a result of the efforts made in the last couple of decades through different programs of basic teacher training. Out of the total teachers at the primary level, $92.6 \%$ are fully trained (i.e., have completed a full package of teacher training conducted by NCED). The proportion of trained teachers is nearly $85 \%$ for secondary and $77 \%$ for lower secondary levels. The share of fully trained teachers at the higher secondary level is $62 \%$. Compared with the teacher training status in primary and secondary levels, the share of trained teachers in lower secondary and higher secondary levels is relatively lower.

\section{Teacher Training Institutions}

NCED was established in 1993 under the MOE as an apex body for human resource development and undertaking activities related to teacher development, capacity development of educational personnel under the MOE, and conducting of research activities in education. ${ }^{27}$ At present, there are four layers of teacher training centers within NCED: (i) education training center, level A (ETC-A); (ii) education training center, level B (ETC-B); (iii) education training center, level C (ETC-C), also called lead resource centers; and (iv) resource center. In addition, the Distance and Open Learning Division within NCED runs training programs through various communication modes to reach teachers living in remote areas. These education training centers look after in-service teacher training while the different universities and their affiliated colleges deliver preservice teacher training.

The government is the largest provider of in-service teacher training in Nepal. While government training centers fall within the administrative mechanism of government and offer limited programs with defined time frames and objectives, the private training providers are not formally registered with NCED or any other agency under the MOE

\footnotetext{
$\overline{27}$ See NCED website (www.nced.gov.np).
} 
umbrella. The distribution of training centers and institutions in terms of their types, management, duration of training, and target levels is presented in Table A2.9.

\section{Table A2.9: Nepal—Training Providers by Type, Management, and Duration of Training and Target Levels}

\begin{tabular}{|c|c|c|c|c|c|}
\hline Training Provider & Number & Management & Duration & Training Type & Target Levels \\
\hline $\begin{array}{l}\text { Education training } \\
\text { centers }\end{array}$ & 34 & $\begin{array}{l}\text { National } \\
\text { Center for } \\
\text { Educational } \\
\text { Development }\end{array}$ & $\begin{array}{l}30 \text { days to } 10 \\
\text { months }\end{array}$ & In-service & $\begin{array}{l}\text { Primary } \\
\text { to higher } \\
\text { secondary }\end{array}$ \\
\hline $\begin{array}{l}\text { Private teacher training } \\
\text { institutes }\end{array}$ & $\begin{array}{l}\text { No official } \\
\text { records } \\
\text { available }\end{array}$ & $\begin{array}{l}\text { Private funders } \\
\text { or companies }\end{array}$ & $\begin{array}{l}\text { Few weeks to } \\
\text { months }\end{array}$ & $\begin{array}{l}\text { Preservice } \\
\text { as well as in- } \\
\text { service }\end{array}$ & $\begin{array}{l}\text { Preprimary to } \\
\text { secondary }\end{array}$ \\
\hline $\begin{array}{l}\text { Higher Secondary } \\
\text { Education Board and } \\
\text { affiliated schools and } \\
\text { colleges }\end{array}$ & & $\begin{array}{l}\text { Higher } \\
\text { Secondary } \\
\text { Education } \\
\text { Board; school } \\
\text { management } \\
\text { committee }\end{array}$ & 2 years & Preservice & $\begin{array}{l}\text { Primary } \\
\text { to higher } \\
\text { secondary }\end{array}$ \\
\hline $\begin{array}{l}\text { Universities and } \\
\text { affiliated colleges }\end{array}$ & $\begin{array}{l}\text { Six universities } \\
\text { (with preservice } \\
\text { teacher } \\
\text { education } \\
\text { and training } \\
\text { programs) }\end{array}$ & $\begin{array}{l}\text { Universities } \\
\text { and the boards } \\
\text { of affiliated } \\
\text { colleges }\end{array}$ & $1-3$ years & Preservice & $\begin{array}{l}\text { Lower } \\
\text { secondary } \\
\text { to higher } \\
\text { education }\end{array}$ \\
\hline $\begin{array}{l}\text { Resource centers and } \\
\text { lead resource centers }\end{array}$ & & $\begin{array}{l}\text { District } \\
\text { education } \\
\text { offices }\end{array}$ & $1-30$ days & In-service & $\begin{array}{l}\text { Primary to } \\
\text { secondary }\end{array}$ \\
\hline $\begin{array}{l}\text { Nongovernment } \\
\text { organizations }\end{array}$ & Not recorded & & $\begin{array}{l}\text { Short (normally } \\
\text { weeks) }\end{array}$ & In-service & $\begin{array}{l}\text { Preprimary to } \\
\text { secondary }\end{array}$ \\
\hline
\end{tabular}

Source: National Center for Educational Development. www.nced.gov.np.

Education training centers. NCED operates 34 ETCs in different locations of the country to carry out teacher training programs. The ETCs are equipped with training halls, rooms, computers, multimedia labs, among others. These 34 ETCs are divided into the following three categories:

(i) 9 ETC-A centers (located in Bara, Bhojpur, Dhanusa, Doti, Kavrepalanchwok, Rupandehi, Sunsari, Surkhet, and Tanahu);

(ii) 20 ETC-B (Baitadi, Banke, Chitwan, Dang, Gorkha, Ilam, Jhapa, Jumla, Kailali, Kanchanpur, Kaski, Kathmandu, Khotang, Morang, Myagdi, Nuwakot, Palpa, Rukum, Parsa, and Saptari); and

(iii) 5 ETC-C (Dhanusha, Doti, Kavrepalanchwok, Rupandehi, and Surkhet).

The geographic distribution of ETCs is not based on standard rules, which can be verified from the fact that there is only one center in the Karnali region while there are two districts with two training centers. 
The availability of staff and resources in an ETC depends largely on availability of donor funding. The training providers within NCED, especially the ETCs, are financed through the government's regular education budget, and permanent staff members are recruited from among the education cadre selected through the public service commission as a teacher trainer. The qualifications, levels, and number of staff differ by the category of ETC. In ETC-A and ETC-B, nontechnical personnel from among the education cadres are appointed as senior trainers or chiefs of the centers.

Lead resource centers and resource centers. Resource centers distributed proportionate to the number of schools located in different (urban, rural, and remote) areas throughout the country are the nearest technical service points for schools, teachers, and village development committees. At present, there are around 1,400 resource centers in the whole of Nepal. Resource center activities are facilitated by resource persons primarily selected from among the teachers in the cluster. The major roles assigned to resource centers include (i) capacity building of primary teachers and school stakeholders such as school management committee members and head teachers, (ii) standardization of school statistics and examinations, and (iii) acting as interface between the DEO and schools in terms of information collection and dissemination. In districts where there are no ETC-A and ETC-B, lead resource centers organize training for secondary school teachers. In the absence of a proper line of control, resources, and clarity in provisions, resource centers are not fully functional in delivering technical support to the schools and teachers. As a result, what was conceived as a good idea is currently costing the government but not delivering any value to improving teacher quality.

Private teacher training providers. Private teacher training providers include a variety of different organizations: nongovernment organizations, private companies, and private schools and colleges. There is no formal database of all private training providers. They offer various short- and long-term teacher training programs, running primarily to benefit private school teachers. Currently, there is no mechanism to judge the quality of their programs or to see if they are aligned with the teacher competency standards. During 2004-2009, NCED mobilized private sector teacher training institutions for attainment of training targets together with their capacity building. However, such agencies are no longer functional since, as per the government record, there are only a few teachers in need of in-service teacher training. Private sector training providers are financed on fees paid by participants, and by donations from external philanthropic funds.

Higher Secondary Education Board and universities. The Higher Secondary Education Board (HSEB), apart from its regular general education programs, also conducts special preservice teacher training programs for primary school teachers. ${ }^{28}$ Meanwhile, the concerned universities, as part of their academic programs, also operate initial and preservice teacher education programs for lower secondary to higher secondary teachers and teacher trainers. The Government of Nepal is in the process of merging the HSEB, an autonomous body, with the DOE as part of the implementation of the School Sector Reform Plan. The HSEB graduates are awarded intermediate degrees in education, and

\footnotetext{
28 The HSEB is a board chaired by the education minister and is guided by separate guidelines issued by the government. It looks after 2 years of secondary education after grade 10 , mostly known as $10+2$. Within the School Sector Reform Plan, higher secondary school is being merged to make 12 years of compiled education. However, in the absence of an amendment in the Education Act, the HSEB still exists, and its merger to the school education system is pending.
} 
are eligible to teach students up to grade 8. In Nepal, universities are organized under the broad umbrella of the MOE through the University Grants Commission as autonomous public bodies. Out of the nine government-funded universities, four of them-Tribhuvan University, Kathmandu University, Purvanchal University, and Nepal Sanskrit Universityare key institutions from the perspective of preservice teacher education. Tribhuvan University, the largest among the universities, has more than $80 \%$ of the higher education enrollment in the country. It offers 1-year (basically a teacher preparation course mostly taken by students from other streams who want to become teachers) and 3-year bachelor's programs, including 2-year master's-level preservice teacher education courses through its Faculty of Education and affiliated colleges located throughout the country to produce qualified teachers (for all levels), teacher educators, and other education experts. ${ }^{29}$

\section{Teacher Training Programs}

There are various types and forms of preservice and in-service teacher training programs currently operating in the country. These training programs include preservice education through the universities as part of higher education, and short- and long-term in-service teacher education programs. In addition, there are various other issues-based programs promoted by the government such as special education training, child-friendly schooling training (with technical support of the United Nations Children's Fund [UNICEF]), and the like (Table A2.10).

At present, the largest ongoing teacher training programs are the preservice teacher education and the teacher professional development (TPD) training program. There is no linkage between preservice courses and the TPD course.

Preservice teacher training program. The purpose of the preservice teacher education program is to develop a competent teaching force with necessary qualifications, technical competence, and in-depth understanding of child psychology and education foundations before one enters the classroom. A total of 158,213 students (48.5\% females) were enrolled in academic year 2010/11 in the preservice teacher education programs of the different universities - a total of 132,685 at the bachelor's level, of which $51.9 \%$ were females. There were 25,228 master's students, of which $30.5 \%$ were females, while the number of students enrolled under the 10+2 system is not available (UGC 2012). The duration of the certification course is 2 years; BEd is 3 years; and MEd is 2 years. The Faculty of Education within Tribhuvan University also offers a 1-year teacher preparation course. ${ }^{30}$ The training programs are funded by individual students.

The curricula of the preservice teacher education programs have been generally structured along three domains of study. The primary domain contains the compulsory areas of study in the foundations of education, mainly philosophy, sociology, and psychology. The second

\footnotetext{
29 The 1-year teacher preparation course was also called Bachelor in Education degree, and often called a 1-year BEd. Purbanchal University conducts both bachelor's and master's programs in education for school-level teachers, while Nepal Sanskrit University conducts 1-year teacher education courses specially targeted at secondary school teachers. The recently organized Mid-western and Far-western universities have also initiated efforts to run teacher education courses. Kathmandu University, the only university organized in the private sector, also conducts teacher education diploma and degree-level courses of 1.5 years duration, targeted at primary, secondary, and higher secondary teachers (UGC 2012).The schools and colleges affiliated with the HSEB and universities include both community and privately managed and owned organizations.

30 There is a provision for a 1-year MEd for students with a master's degree in any other field of study, and a 1-year BEd or postgraduate diploma for students with bachelor's degree from any other faculty.
} 


\section{Table A2.10: Nepal—Government Professional Development Program (preservice and in-service)}

\begin{tabular}{|c|c|c|c|c|c|c|}
\hline $\begin{array}{l}\text { Training } \\
\text { Programs }\end{array}$ & Providers & $\begin{array}{c}\text { Entry } \\
\text { Requirements }\end{array}$ & Duration & $\begin{array}{c}\text { Final } \\
\text { Examination }\end{array}$ & $\begin{array}{c}\text { Qualification } \\
\text { Granted }\end{array}$ & Status \\
\hline $\begin{array}{l}\text { Preservice } \\
\text { teacher training } \\
\text { program }\end{array}$ & $\begin{array}{l}\text { Universities } \\
\text { and affiliated } \\
\text { colleges, HSEB }\end{array}$ & $\begin{array}{l}\text { Completion } \\
\text { of certain } \\
\text { education levels }\end{array}$ & $\begin{array}{l}\text { 1-4 years } \\
\text { depending } \\
\text { on level }\end{array}$ & $\begin{array}{l}\text { Internal } \\
\text { as well as } \\
\text { external }\end{array}$ & $\begin{array}{l}\text { Education } \\
\text { degree }\end{array}$ & Ongoing \\
\hline $\begin{array}{l}\text { In-service } \\
\text { training }\end{array}$ & $\begin{array}{l}\text { NCED and } \\
\text { ETCs }\end{array}$ & $\begin{array}{l}\text { Permanent } \\
\text { government } \\
\text { teachers }\end{array}$ & 10 months & $\begin{array}{l}\text { Internal } \\
\text { as well as } \\
\text { external }\end{array}$ & $\begin{array}{l}\text { Grading } \\
\text { (score) }\end{array}$ & Completed \\
\hline $\begin{array}{l}\text { Teacher } \\
\text { professional } \\
\text { development }\end{array}$ & $\begin{array}{l}\text { NCED, ETCs, } \\
\text { and resource } \\
\text { centers }\end{array}$ & $\begin{array}{l}\text { All government } \\
\text { school teachers }\end{array}$ & 30 days & Not available & $\begin{array}{l}\text { Training } \\
\text { certificate }\end{array}$ & Ongoing \\
\hline $\begin{array}{l}\text { Head teacher } \\
\text { training } \\
\text { program }\end{array}$ & NCED, ETCs & $\begin{array}{l}\text { All government } \\
\text { and private } \\
\text { school head } \\
\text { teachers }\end{array}$ & 7 days & Not available & $\begin{array}{l}\text { Participation } \\
\text { certificate }\end{array}$ & Ongoing \\
\hline $\begin{array}{l}\text { ECD in-service } \\
\text { training }\end{array}$ & $\begin{array}{l}\text { District } \\
\text { education } \\
\text { offices, NGOs }\end{array}$ & $\begin{array}{l}\text { ECD facilitators } \\
\text { (school and } \\
\text { community- } \\
\text { based ECDs) }\end{array}$ & 16 days & Not available & $\begin{array}{l}\text { Training } \\
\text { certificate }\end{array}$ & Ongoing \\
\hline $\begin{array}{l}\text { Issue-based } \\
\text { specific training } \\
\text { programs }\end{array}$ & $\begin{array}{l}\text { NCED, ETCs, } \\
\text { NGOs }\end{array}$ & $\begin{array}{l}\text { Government } \\
\text { school teachers }\end{array}$ & Weeks & Not available & $\begin{array}{l}\text { Participation } \\
\text { certificate }\end{array}$ & Ongoing \\
\hline
\end{tabular}

ECD = early childhood development, ETC = education training center, HSEB = Higher Secondary Education Board, NCED = National Center for Educational Development, NGO = nongovernment organization .

Source: National Center for Educational Development. www.nced.gov.np.

domain comprises the basic subjects of school curricula, including Nepali language, English language, mathematics, science, and social studies, with their pedagogies. The third domain contains the areas of study grouped with a view to cater to the needs of students with different interests and broadening their horizons while supplementing the major areas of study. The second and third domains are for electives, although English and Nepali as subjects are compulsory for a 3-year BEd. The courses within the curricula are academically structured in a framework that includes objectives, content, teaching and learning methods and strategies, evaluation procedures, and a list of references..$^{31}$ The preservice program has followed this pattern.

For preservice programs organized and conducted through the HSEB and the universities, the faculty members are often recruited and selected by the university or the affiliated higher education institution following its board's standard guidelines. Their competencies

\footnotetext{
31 The course outline generally follows a structure in which objectives are stated in terms of specific behavioral outcomes with contents categorized under homogeneous units followed by a loose outline of teaching and learning strategies. Finally, a tentative outline of plausible evaluation strategies is given with relevant references at the end.
} 
and the quality of their qualifications are not known. The examination boards of the universities and HSEB conduct external examinations to award degrees, which is the only available quality monitoring mechanism. Most of the teacher education certificates and degrees are recognized as equivalent on a reciprocal basis with those of their faculties within the same or the other universities. NCED has little or no authority or role to play in setting or monitoring of standards for preservice education and training programs.

Teacher professional development training program. The TPD program was initiated under School Sector Reform Program after attainment of the target of the basic 10-month teacher training to permanent teachers working in the government schools. The main objective of the program is to continuously deliver short-term in-service teacher training programs based on teachers' competency gaps. The beneficiaries are the teachers working in community schools (public schools or government schools), both permanent and temporary. Every year, around 68,463 teachers on average have benefited from the TPD program. Based on the data provided by NCED, around $46 \%$ of the total TPD modules had been delivered until 2013. Out of 127,740 basic education teachers, an estimated 60,200 had received TPD training; out of 19,584 secondary teachers, around 8,263 had received it.

Overall, the TPD program is a 30-day-long package divided into three 10-day modules. It involves in-house face-to-face training, practical implementation of the training lessons in classrooms and direct monitoring and supervision by trainers, and continuous monitoring and evaluation of performance (NCED 2010a, 2010b, 2012) (Table A2.11). ${ }^{32}$

\section{Table A2.11: Nepal-Teacher Professional Development Training Phases and Activities}

\begin{tabular}{|l|l|c|}
\hline & \multicolumn{1}{|c|}{ Activities } & Number of Days \\
\hline Part (Phase) 1 & In-house face-to-face training workshop & 5 days \\
\hline Part (Phase) 2 & Practical self-study exercise at the school and classroom levels & 3 days \\
\hline Part (Phase) 3 & $\begin{array}{l}\text { In-field monitoring and support by trainers through } \\
\text { instructional counselling }\end{array}$ & 2 days \\
\hline
\end{tabular}

Source: NCED 2012 Training for Trainers for Teacher Professional Development Manual.

TPD training programs are very flexible, and content will vary based on the needs of the teachers. The modules are developed and approved locally. Typical training content includes strengthening subject matter knowledge and teaching skills where the teachers encounter difficulties, classroom delivery techniques, use of teaching and learning materials, and so on. TPD training is delivered through resource persons, roster trainers (resource teachers), or ETC-based trainers who have received special training. Resource persons facilitate training for primary school teachers, while roster trainers or ETC trainers work with lower secondary and secondary teachers.

32 Prior to the implementation of the TPD program, the curriculum of the basic 10-month in-service teacher training conducted by NCED was well structured with four defined modules of 2.5 months each, the middle two of which were combined into one to permit the program to be completed in just three modules. The first module dealt with the fundamentals of education; the middle two modules covered pedagogy to augment the teaching of the subjects of school curriculum; and the fourth module contained the study of other areas useful for strengthening the professional foundations of teaching as a career. 
In addition to the TPD program, NCED has other programs and interventions that include (i) issue-based training programs (such as teaching in the mother tongue, special education, and teaching in the English language); (ii) a leadership capacity-building program for head teachers and school management committees; (iii) management training for education managers working at central, regional, and district levels; (iv) open school program; and ( $v$ ) a School Leaving Certificate support program aimed at developing a package to better prepare students and teachers for the School Leaving Certificate examinations (Table A2.12).

\section{Table A2.12: Nepal-Training Programs Offered by National Center for Educational Development Other than General Teacher Professional Development Training}

\begin{tabular}{|c|c|c|c|}
\hline Training Program & Beneficiaries & Details & Remarks \\
\hline $\begin{array}{l}\text { Head teacher training } \\
\text { program }\end{array}$ & Head teachers & $\begin{array}{l}\text { 30-day-long leadership } \\
\text { development training with } 10 \\
\text { days of in-house training, } 18 \\
\text { days of self-study, and } 2 \text { days } \\
\text { of direct contact class }\end{array}$ & $\begin{array}{l}\text { There are also similar training } \\
\text { programs targeted at school } \\
\text { management committees } \\
\text { but organized less frequently }\end{array}$ \\
\hline $\begin{array}{l}\text { Training of education } \\
\text { managers }\end{array}$ & $\begin{array}{l}\text { Education cadre (district } \\
\text { education officials, regional } \\
\text { education officials) }\end{array}$ & $\begin{array}{l}\text { Short-term courses (mostly } \\
\text { of about a week) }\end{array}$ & $\begin{array}{l}\text { Such training programs are } \\
\text { normally conducted directly } \\
\text { by the National Center for } \\
\text { Educational Development }\end{array}$ \\
\hline $\begin{array}{l}\text { Training for resource } \\
\text { persons and resource } \\
\text { teachers }\end{array}$ & $\begin{array}{l}\text { Resource persons; resource } \\
\text { teachers (roster trainers) }\end{array}$ & $\begin{array}{l}\text { 12-day-long training } \\
\text { of trainers for resource } \\
\text { teachers; in-service teacher } \\
\text { training for resource persons }\end{array}$ & \\
\hline $\begin{array}{l}\text { Training on special } \\
\text { education }\end{array}$ & $\begin{array}{l}\text { Teachers in special schools } \\
\text { (special education) }\end{array}$ & $\begin{array}{l}\text { Adopted based on TPD } \\
\text { format, and customized for } \\
\text { special education }\end{array}$ & $\begin{array}{l}\text { Training is organized in TPD } \\
\text { structure }\end{array}$ \\
\hline $\begin{array}{l}\text { Training on teaching } \\
\text { in mother tongue }\end{array}$ & $\begin{array}{l}\text { Teachers in government } \\
\text { schools that adopted } \\
\text { multilingual or mother } \\
\text { tongue education }\end{array}$ & $\begin{array}{l}\text { Adopted based on TPD } \\
\text { format, and customized for } \\
\text { teachers who need to teach } \\
\text { in multiple languages or } \\
\text { mother tongue }\end{array}$ & $\begin{array}{l}\text { Training is organized in TPD } \\
\text { structure }\end{array}$ \\
\hline $\begin{array}{l}\text { Training for teachers } \\
\text { to use English as a } \\
\text { medium of instruction }\end{array}$ & $\begin{array}{l}\text { Teachers from community } \\
\text { schools who have started to } \\
\text { use English as a medium of } \\
\text { instruction in the basic level }\end{array}$ & $\begin{array}{l}\text { 10-day-long training } \\
\text { organized through education } \\
\text { training centers }\end{array}$ & $\begin{array}{l}\text { The list of trainees is } \\
\text { recommended by district } \\
\text { education offices }\end{array}$ \\
\hline $\begin{array}{l}\text { Training for teachers } \\
\text { in religious schools }\end{array}$ & $\begin{array}{l}\text { Teachers in religious schools } \\
\text { (gumba, vihar, ashram, } \\
\text { gurukul, and madrasah) }\end{array}$ & $\begin{array}{l}\text { Adopted based on TPD } \\
\text { format, and customized for } \\
\text { teachers in religious schools }\end{array}$ & \\
\hline
\end{tabular}

TPD = teacher professional development.

Source: National Center for Educational Development. www.nced.gov.np. 
Private sector-led teacher training programs. There are various teacher training programs organized through the private sector as well, though detailed records are not available and the number of teachers who benefit from such training programs will be small. For example, Rato Bangala Foundation runs a teacher training program targeting primary school teachers from government schools. Innovative Forum for Community Development, with financial and technical support from UNICEF, has been training teachers on child-friendly schools, targeting primary school teachers. The training promotes grade teaching (one teacher for one grade), and effective use of learning materials inside the classroom. The training is around a week long. World Education and UNICEF partners organized teacher training on the Quality Education Resource Package during 2005-2009, which delivered training in a cascade model and provided resource materials to teachers (RIDA 2009). The Quality Education Resource Package included books and materials on various aspects of childfriendly teaching and learning, which were delivered to schools along with relevant training programs. The lessons from such teacher training programs were not mainstreamed.

\section{Delivery of Teacher Training Programs}

In general, the teacher education and training programs use the conventional mode of delivery: lecturing interspersed with questions and answers. Use of discussion, group work, or presentations is common in in-service programs, as the number of participants is reasonable and materials and/or audiovisual aids are available. Universities and the HSEB use very traditional practices and have overcrowded classes. However, these conventional modes of delivery have shifted dramatically in recent years due to increased demand for the participatory approach as well as the expanded use of ICT-based delivery modes. Universities have taken steps to introduce the use of ICT in their teacher education programs at both the bachelor's and master's levels. The Faculty of Education of Tribhuvan University has introduced a master's level ICT course, and offers the bachelor's level in its five constituent campuses and five affiliated campuses. Moreover, open and distance learning for campus teachers is being contemplated with collaboration between Hamk University of Finland and NCED.

Although the Curriculum Development Centre provides teacher guides on improving instruction in the classroom, the teacher education providers have not yet adopted those same methodologies. In addition, there is limited linkage of teacher training to trainee assessment. The important aspects of post-training monitoring, supervision, and performance assessment have been overlooked in all of the teacher training programs implemented so far. The teacher trainers seem to concur that despite improvement in recent years, the training methodology is still not compatible with the desired standards of quality. ${ }^{33}$ The dominant use of the lecture method for teacher training is for two main reasons. First the availability of facilities (including furniture, projector, cafeteria, etc.) differs widely among the institutions, and some training centers (ETCs and resource centers) have none at all. Some resource centers that also conduct teacher training for lower secondary and secondary-level teachers do not have any ICT equipment. ${ }^{34}$ Second, the teacher trainers do not have the technical expertise to switch to an upgraded modality. The shift will require slightly different procedures for preparation, delivery, and assessment.

\footnotetext{
33 Based on discussion with trainers in ETCs.

${ }^{34}$ Based on observations of resource centers and discussions with resource persons, ETC trainers, and schoolteachers.
} 
It is encouraging to note that NCED and ETCs are very positive toward the possible use of ICT in TPD programs. ${ }^{35}$

There is very limited or no linkage between research and delivery of teacher training programs at present. Universities are involved in research and program design through their independent research wings, such as the Research Centre for Educational Innovation and Development. There is no built-in system where NCED and the universities are connected. NCED normally contracts out the research assignments, which are very limited, to research institutions and individuals through competitive selection. However, such external research has limited use in program development. The required coordination between NCED (the largest in-service training provider) and the universities (the largest preservice training providers) is missing.

\section{Quality Standards for Teacher Training Providers}

The responsibility to ensure quality training through government-owned training providers, especially ETCs, lies with NCED. However, quality standards are not in place except for a practice during the Teacher Education Project for the accreditation of ETCs. Moreover, there is clearly a conflict of interest as NCED acts as a training provider and a quality assurance agency at the same time. For preservice courses, the University Grants Commission is responsible for preparing, circulating, and enforcing quality standards. There is no government mechanism for monitoring the activities and quality of private training providers.

There are two sources of trainers for teacher training conducted by government agencies: the education cadre (hired by the public service commission to work as teacher trainers); and schoolteachers (normally deputed as teacher trainers for a specified period). The competence of trainers from education cadres varies depending on their posts and responsibilities. Teacher trainers are equivalent to third-class positions (section officers) within the MOE, though they are recruited especially for teacher training and must possess at least a bachelor's degree. However, all ETCs have nonteacher trainers as heads of the unit, ironically called "senior trainers." Second-class government officers from the education cadre are heading the ETC-A centers and third-class government officers are given officer-in-charge responsibility in ETC-B centers. Regardless of the source of recruitment, all teacher trainers are required to have received relevant training for trainers from NCED.

The qualification requirements for teacher trainers have not been updated, although the minimum qualification requirements for teachers have been increased. Consequently, some teacher trainers have only a bachelor's degree, while others have a master's. Trainees are sometimes more qualified than their trainers, which can create a psychological barrier. ${ }^{36}$

\footnotetext{
35 Based on discussion with the training unit (NCED and ETCs).

${ }^{36}$ Reported during discussions with trainers in ETCs.
} 


\section{E. Programs and Projects for Teacher Education Reform}

The Government of Nepal implemented two education programs from 2008 to 2013: the Education for All, and the Secondary Education Support Program implemented in 20042009. These programs were succeeded by the School Sector Reform Program, which was implemented in 2009-2015. There had been some reform initiatives made during these periods (Table A2.13).

Table A2.13: Nepal—Brief Specifications of Teacher Education Reforms Initiated in the Post-2008 Period

\begin{tabular}{|c|c|c|c|c|}
\hline Program & Category & Reform Initiatives & $\begin{array}{l}\text { Objectives } \\
\text { and/or Activities }\end{array}$ & $\begin{array}{l}\text { Status of Implementation } \\
\text { and/or Results }\end{array}$ \\
\hline \multirow[t]{3}{*}{$\begin{array}{l}\text { Education } \\
\text { for All }\end{array}$} & Policy decision & $\begin{array}{l}\text { Decentralized } \\
\text { recruitment of } \\
\text { teachers }\end{array}$ & $\begin{array}{l}\text { To enable timely } \\
\text { recruitment of } \\
\text { qualified local teachers } \\
\text { accountable to } \\
\text { school management } \\
\text { committees }\end{array}$ & $\begin{array}{l}\text { The decentralization of teacher } \\
\text { recruitment led to immediate filling } \\
\text { of teacher posts at the local level. } \\
\text { However, the mechanism also } \\
\text { received much criticism on the } \\
\text { grounds of improper selection. }\end{array}$ \\
\hline & Policy & Teaching license & $\begin{array}{l}\text { To standardize } \\
\text { minimum competency } \\
\text { among teachers }\end{array}$ & $\begin{array}{l}\text { The Teacher Service Commission has } \\
\text { conducted a teaching license exam } \\
\text { with heavy inflow of youths taking } \\
\text { part in the license exams. All newly } \\
\text { recruited teachers in public schools } \\
\text { are required to get a teaching license, } \\
\text { but private schools did not follow the } \\
\text { licensing mechanism. }\end{array}$ \\
\hline & $\begin{array}{l}\text { Teacher } \\
\text { education }\end{array}$ & $\begin{array}{l}\text { Teacher } \\
\text { Education } \\
\text { Project }\end{array}$ & $\begin{array}{l}\text { Deliver in-service } \\
\text { teacher training to all } \\
\text { government teachers }\end{array}$ & $\begin{array}{l}\text { The project was completed in } 2009 \\
\text { with the successful result of delivering } \\
\text { in-service teacher training to more } \\
\text { than } 95 \% \text { of permanent teachers. }\end{array}$ \\
\hline \multirow[t]{2}{*}{$\begin{array}{l}\text { School } \\
\text { Sector } \\
\text { Reform } \\
\text { Program }\end{array}$} & Policy decision & $\begin{array}{l}\text { Teacher } \\
\text { qualification } \\
\text { upgrade }\end{array}$ & $\begin{array}{l}\text { Increase the basic } \\
\text { qualification } \\
\text { requirement for basic } \\
\text { schoolteachers up to } \\
\text { grade } 12\end{array}$ & $\begin{array}{l}\text { The provision was implemented } \\
\text { effectively, providing opportunity for } \\
\text { teachers with lower qualifications } \\
\text { to upgrade their academic profile } \\
\text { through a special course offered by } \\
\text { the Higher Secondary Education } \\
\text { Board. The program was successful in } \\
\text { establishing uniformity in minimum } \\
\text { qualifications among teachers. }\end{array}$ \\
\hline & $\begin{array}{l}\text { Teacher } \\
\text { education } \\
\text { program }\end{array}$ & $\begin{array}{l}\text { Teacher } \\
\text { preparatory } \\
\text { course- } \\
\text { 1-year bridge } \\
\text { course }\end{array}$ & $\begin{array}{l}\text { Enable students from } \\
\text { faculties other than } \\
\text { education to enter the } \\
\text { teaching force, especially } \\
\text { for subjects such as } \\
\text { science, mathematics, } \\
\text { and English. }\end{array}$ & $\begin{array}{l}\text { The program was proposed under } \\
\text { the School Sector Reform Program. A } \\
\text { 1-year Bachelor of Education program } \\
\text { is available to provide the foundation } \\
\text { and other preservice education to the } \\
\text { potential teacher. }\end{array}$ \\
\hline
\end{tabular}


Table A2.13 continued

\begin{tabular}{|c|c|c|c|c|}
\hline Program & Category & Reform Initiatives & $\begin{array}{l}\text { Objectives } \\
\text { and/or Activities }\end{array}$ & $\begin{array}{l}\text { Status of Implementation } \\
\text { and/or Results }\end{array}$ \\
\hline \multirow[t]{2}{*}{$\begin{array}{l}\text { School } \\
\text { Sector } \\
\text { Reform } \\
\text { Program }\end{array}$} & $\begin{array}{l}\text { Teacher } \\
\text { education } \\
\text { program }\end{array}$ & $\begin{array}{l}\text { Teacher } \\
\text { professional } \\
\text { development } \\
\text { program }\end{array}$ & $\begin{array}{l}\text { Provide demand-based } \\
\text { teacher training to } \\
\text { government school } \\
\text { teachers }\end{array}$ & $\begin{array}{l}\text { More than } 40 \% \text { of the total program } \\
\text { modules have already been delivered } \\
\text { to teachers following the demand } \\
\text { collection and local determination of } \\
\text { training content. }\end{array}$ \\
\hline & $\begin{array}{l}\text { Capacity } \\
\text { building of } \\
\text { system }\end{array}$ & $\begin{array}{l}\text { Online and } \\
\text { offline training }\end{array}$ & $\begin{array}{l}\text { Provide distance-based } \\
\text { support to teacher } \\
\text { trainers to fulfill their } \\
\text { learning and capacity } \\
\text { gaps. }\end{array}$ & $\begin{array}{l}\text { The offline online training is currently } \\
\text { being implemented. Since the } \\
\text { participants are not fully familiar with } \\
\text { information and communication } \\
\text { technology, implementation has } \\
\text { suffered. }\end{array}$ \\
\hline
\end{tabular}

Source: Compiled by the author.

The next sections present the reform initiatives and their outcomes, as well as the lessons learned.

\section{Decentralized Teacher Hiring and Uniform Licensing}

The authority to recruit teachers was decentralized to the school level. SMCs in community schools were authorized to recruit temporary teachers through a standard competitive process. To facilitate the recruitment of teachers with minimum competency, the TSC started to provide a teacher license for various levels, and the license was made mandatory for teachers.

Teacher licensing was an encouraging effort to establish a form of teacher competency monitoring following preservice education. As the government machinery has limitations in its ability to efficiently deploy teachers based on local needs, the decentralized teacher recruitment policy enabled smoother operation of schools. Considering that teacher recruitment through the district education offices (DEOs) and other existing government mechanisms has often been politically influenced and biased, the delegation of such an important decision to the school level reflects the government's genuine commitment to decentralization.

Some of the key lessons learned through implementation of the policy include the following: (i) SMCs can successfully recruit teachers if the recruitment standards are strictly enforced and monitored; (ii) the teachers recruited by an SMC are accountable to the SMC; and (iii) for decentralization to succeed, the government needs not only to provide necessary technical support, but also to trust that communities can make rational decisions. The existing provision of teacher licensing by the TSC and teacher recruitment by SMCs for all posts should be enforced strongly.

\section{Teacher Education Project}

The Teacher Education Project was implemented during 2002-2009 with the overall objective of institutional capacity building, teacher skill improvement, and enhancing participation of disadvantaged groups in school education. One of the key features of the project was the extensive efforts toward providing basic teacher training opportunities to 
all serving teachers under the in-service training program. The project also contributed to improved infrastructure for teacher training providers, and organized international exposure visits for teacher trainers and NCED officials.

Supply-based teacher training, regardless of its rigor, has not shown substantial impact on classroom performance in the absence of adequate monitoring and supervision. It requires strong monitoring, supervision, and a supportive environment at the school level. The private sector can also be mobilized to deliver teacher training. The mechanism adopted under the Teacher Education Project can help create a pool of trained teacher trainers outside the government system.

\section{Qualification Upgrade and Standardization through Teacher Preparatory Course}

The School Sector Reform Plan (2009-2015) raised the minimum qualification requirements for primary school teachers, who must now upgrade their qualifications to the level of higher secondary education. Teachers with qualifications lower than grade 12 have can take a special make-up course through the HSEB and the Tribhuvan University Faculty of Education. The plan has further arranged for a teacher preparation course (preservice teacher training) through universities for teachers with academic backgrounds other than education.

Although the provision to upgrade qualifications has been in place for only a relatively short period, it does not appear to be working as expected. There are no specific indications that the program has enhanced teacher competency to the desired level because the make-up courses lack adequate rigor, and the trainees did poorly in the examinations at the end of the course. The teacher preparation course should be institutionalized or harmonized with existing preservice courses rather than implemented as a separate program.

\section{Demand-Based Teacher Professional Development}

The TPD program is an ongoing demand-based training program initiated in 2009 for all teachers working in community schools. As described in detail in earlier sections, teachers are provided with three 10-day modules of TPD training, each of which includes face-toface training and school-based action research. The training is delivered through resource centers for basic education teachers, and through lead resource centers and education training centers for secondary-level teachers.

The program initiated a completely different approach to teacher training compared with previous training programs, and was very relevant considering the coverage of supplybased preservice and in-service teacher training was already very high. TPD contributed to human resource development through development of a local roster of trainers, and through preparation and implementation of a teacher training manual. TPD also helped to make resource centers functional in delivering the services they were originally anticipated to deliver.

Local-level teacher training can be cost-effective and sustainable. The approach of mobilizing roster trainers from the local level recognized teachers as experts, and thus motivated them to perform better. The clustering and assessments of common needs during the design of the training manual and during selection of participants led to selection 
of general needs, although the original objective of TPD was to identify and address individual needs. On the whole, TPD is yet to be effective in bringing about changes inside the classroom.

\section{F. Analysis of the Teacher Education and Training System}

The main issue in Nepal is how to address the weak performance of classroom teachers. The overall teacher development mechanism in the country is faced with two major challenges: ineffective implementation of the available provisions, and readjusting the teacher development program to align with 21st century teaching and learning. Experience has shown that the majority of teachers serving the school system are not motivated. ${ }^{37}$ There might be several reasons for this, including (i) absence of a performance-based incentive and promotion mechanism; (ii) career stagnation in the absence of a functional teacher promotion mechanism; (iii) limited learning and professional development opportunities; (iv) low salary compared to the market price, coupled with irregular distribution of salary; ( $v$ ) irregular attendance of teachers and limited time spent by teachers inside the classroom; (vi) unavailability of suitable learning environment within the classroom; (vii) lack of a constructive feedback cycle among teachers at the school level; and (viii) lack of monitoring of teacher performance made worse by the fact that teachers have security of tenure. ${ }^{38}$ There is no competitive environment in the school.

\section{Financial Resource Management}

Though the education sector receives nearly $17 \%$ of the total public expenditure, the allocation for TPD is negligible as the major chunk of the budget is consumed by teacher salaries (nearly three-fourths of School Sector Reform Program expenditure according to Cummins et al. [2012]). NCED, which spearheads teacher development, receives only a small portion of the budget compared to the DOE, which looks after educational administration and management. The financial crunch becomes clearly visible at the field level when comparing spending between the Teacher Education Project period and the post-project period. Nowadays, the ETCs do not get even the bare minimum needed to properly operate and maintain the training centers. ${ }^{39}$ This curtails training activities, including TPD. For TPD training, the budget available to cover food and transportation costs for participants is very low. Only a portion of eligible teachers receive training, and the allocation for monitoring and supervision at the school level is also inadequate. In addition to the small budget available for TPD, there are also issues of efficiency and waste. There are many ETCs with parallel or duplicative functions; existing in-service training (i.e., TPD training) is mass-based; and yet the government still spends on in-service training instead of investing in preservice.

The budget allocated for teacher salaries is high due to recruitment of more teachers than necessary (if we consider student-teacher ratio as a basis). However, there are too many teachers in some areas, and teacher shortages in others. In some locations where there is

\footnotetext{
37 Based on the common opinion of study respondents.

38 Based on responses from teachers, district education office, head teacher, and ETCs.

39 Reported by ETC officials.
} 
perceived shortage of teachers, the quota is increased. Hence, teacher salaries take a large chunk of the education budget, much higher than required.

The main reason behind the resource constraint is the low government priority accorded to the professional development of teachers. While the major cost of the preservice teacher education program is covered through student fees, and the basic course of in-service teacher training targeted at permanent teachers already completed, the existing TPD training programs (which are not effective enough) consume a large share of the TPD budget, and also do not fall under government priorities.

\section{Human Resource Constraints}

Apart from limited financial resources, the TPD mechanism also suffers from human resource constraints, especially in terms of unavailability of high-level staff in researchbased institutional development. Experience also showed that the capacity-building programs did not add the expected value, as the capacity building of the individuals could not be transformed into the capacity building of institutions. The existing mechanism for human resource arrangements (including fresh recruitment, transfer, and promotion) does not require specific competencies for personnel in NCED and ETCs. The distribution of the education cadre in NCED, the Curriculum Development Centre, the DOE, and DEOs is not systematically arranged according to their competency and relevant academic qualifications.

Inadequate research and innovations. The teacher development system has a very limited research base, and there is also lack of initiative to utilize the available evidence-based research. Very few research studies are conducted within NCED itself. Those that are conducted do not provide a robust research base for policy making, the main barriers to which include (i) lack of systemic orientation toward research and evidence-based policy making, (ii) negligible allocation of budget for research and innovation, (iii) limited research-related expertise of available staff, and (iv) limited partnership with universities and their research wings. An NCED committee consisting of the deans of the university faculties of education has been formed to enhance research and innovations in teacher development. However, the committee's influence has thus far remained invisible and has not led to meaningful research and evidence-based policy making. The problem is entrenched deeper in the wings of NCED, such as ETCs, which have limited autonomy and severe resource constraints. Though the concept of action research has been initiated time and again through TPD training at the school, ETC, and NCED levels, this initiative has been confined to simply carrying out certain routine assignments.

Political influence in teacher management. The chief barrier behind problems related to teacher management, especially recruitment and placement, has been partisan political influence, which was aggravated especially after the restoration of multiparty democracy in 1990. Though the TSC was set up during the 1990s for the systematization of the teaching service, teachers continued to be recruited in schools, first through political decisions, and later adjusted to permanent posts through the TSC. ${ }^{40}$ The skewed distribution of teachers in urban areas is a result of this political influence in teacher recruitment and transfer. Another form of political influence in teacher development is through teacher

\footnotetext{
40 This inability to recruit qualified teachers made it necessary for government to arrange extensive in-service training.
} 
unions, which are organized as the related wings of larger political parties, and thus equipped with strong voices on policy matters of teacher management. For example, the government initiative to transfer school management to the community, with an enhanced role for SMCs in hiring, monitoring, and managing teachers at the school level, has been vehemently opposed by the teacher unions for more than a decade, which are concerned about job security if management is transferred to the community. Similarly, policy measures related to teacher qualification upgrading, ending tenure of temporary teachers, and teacher redeployment have been repeatedly opposed by the teacher unions.

\section{Relevance of the Current Teacher Development System: Economic and Quality}

Though TPD programs have evolved over the years, teacher development as a system has remained monotonous and has yet to emerge as a comprehensive national system. So far, it mostly covers permanent teachers working in the government-funded community schools. Although there are agencies from nongovernment organizations and the private sector involved in implementing short-term and often issue-based teacher training, the involvement of nonstate actors in teacher education policy development and governance is very limited. As there are no partnership arrangements between NCED and ETCs with private providers in delivering such training programs, the potential of nonstate sectors to collaborate with government in delivering in-service training for untrained teachers has not been harnessed adequately.

Partial relevance of the existing teacher development system. The teacher development system is not properly aligned with the desired outcomes of the education system at large, and adequate monitoring mechanisms and research to check the impact are also lacking. Though there is inadequate concrete empirical evidence to assess the effectiveness of the teacher development system, it appears to be clearly underperforming if student achievement and the internal efficiency of the education system are taken into consideration. For instance, all national assessments carried out at different times (EDSC 1997, 1999, 2001, 2003, 2008; ERO 2013) have shown low learning achievement of students. Looking at overall outcomes, the performance is not good, with less than half of the students passing the school exams; only $20 \%$ reaching grade 10 ; and failing students leaving school and forming the bulk of the unemployed population. ${ }^{41}$ While the reasons for this astounding dropout rate need to be explored, poor performance of teachers and schools is one definite contributing factor (Shams, Thams, and Parajuli 2013).

Inadequate existing teacher development system. The existing teacher development system is not adequate to meet contemporary national and international human resources demand. ${ }^{42}$ Both preservice and in-service teacher training programs have overlooked the need to update teachers according to the demands of globalization. While schools in recent years are taking initiatives to introduce English as a medium of instruction and to use computers as teaching aids, the teacher education system has not been able to

41 If the results of the School Leaving Certificate examinations published on 11 June 2013 are considered, it is found that only around $41 \%$ of students have managed to pass the examination, and majority of the students who failed are from community schools (The Kathmandu Post, 2 June 2013).

42 The focus of this system so far has been largely on capacity building of teachers to deliver content covered by the textbook and curriculum in the classroom. This could be because the main goal of the teacher development system during the last 2 decades was to enhance the capacity of teachers to deliver the desired content in the classroom. The teachers available and recruited during that period required additional technical backstopping. 
produce teachers with required competencies. Although a small beginning appears to have been made through TPD training, there are no comprehensive arrangements available to update and equip teachers on the use of modern technology in the domains of education and pedagogy. The production of teachers with a good understanding of the foundations of education and skills of pedagogy is an important goal of teacher education, but has not been achieved at the expected level. Nevertheless, some efforts have been initiated within the teacher development system to educate teachers in delivering value-based education, which, apart from the basic skills and understanding of education foundations, also requires teachers to be equipped with child-friendly teaching methods. Similarly, positive results, such as a reduction in cases of corporal punishment, have been observed as the impact of reforms in teacher education (NCED 2009).

Insufficient production of quality teachers in critical and high-demand subjects. There is a shortage of competent teachers in certain subjects (e.g., English, mathematics, and science) for the secondary level. The enrollment of students in preservice education courses is skewed in some subjects such as Nepali, health and population, and social studies, as it is easy to graduate in these subjects. ${ }^{43}$ Many students fail in mathematics, English, and science, and the scores in these subjects largely determine the capability and competency of students in the market. This has also led to lower competency of teachers to teach mathematics and English. However, the existing mechanism is unable to produce teachers of adequate quality and number for such subjects. Moreover, there is no provision of incentives for high-demand subjects. Good students with higher grades normally do not enroll in the education faculty. The students who enroll in preservice education courses for studying subjects such as mathematics, English, and science are not only few, but also lack adequate competency to teach these subjects. ${ }^{44}$ In addition, the policy also appears to prevent the entry of qualified subject experts with majors in mathematics, science, and English into the teaching service as it requires all new entrants to complete a preservice course in education before applying for a teaching license. The government has made no efforts to regulate enrollment in preservice courses and faculties based on demand, and has also not promoted enrollment in certain subjects (i.e., there are no scholarships or other provisions to promote enrollment in English and mathematics).

Ineffective entry-level competency standards. While there are competency standards for entry, such provisions became ineffective in ensuring the availability of competent and qualified teachers. Every teacher should obtain a license through an examination conducted by the TSC, and in order to appear in that examination, they should have completed a preservice teacher education course. The School Sector Reform Plan (20092015) increased the required level of qualification for primary school teachers to grade 12. The provision led to uniform competency requirements for basic education teachers (those teaching in grades $1-8$ ). Since grades $6-8$ require subject-area teachers slightly different skill sets compared with grades $1-5$ teachers, it led to upgrading of qualification for primary teachers, but competency for lower secondary-level teachers remains the same. The core issues attached to teacher competency standards are as follows: (i) the competency standards do not include all necessary characteristics that a teacher should possess; (ii) the competency testing and examination system at the beginning is fairly weak since it overlooks the practical performance of teachers; (iii) the preservice teacher

\footnotetext{
${ }^{43}$ Based on discussion with preservice students.

${ }^{44}$ Based on discussion with preservice students, teachers, and ETC trainers.
} 
education programs have been attracting mostly low achiever students who eventually enter the teaching profession; (iv) the entry-level competency test has had very limited impact on ensuring quality of existing teachers, since it has only been in force in recent years, and the teachers working before these arrangements obtained their license without any competency test); ( $v$ ) the performance monitoring mechanism, though available in principle, does not exist in practice; and (vi) there is no demand for performance monitoring since there are no incentives nor promotions tied to meeting quality standards. In effect, once teachers are recruited in the system, they are not motivated to demonstrate competence in performance as a teacher during the entire service period.

Nonexistent functional monitoring and evaluation mechanism to assess outcomes. Juxtaposition of teacher performance in relation to student performance is not in practice so far. While program effectiveness studies have been carried out by NCED, none of them have looked into the longitudinal data based on a standard research evaluation model of pre- and post-training scenarios; neither comparisons between control and intervention groups have used a kind of teacher quality index or student tests (Shams, Thapa, and Parajuli 2013). There is no functional monitoring mechanism to track performance of teachers regularly. The STRO has a very limited role in this context. The DOE has a monitoring section to look after the overall performance of schools and compile data on teachers and students, which are published every 6 months as flash reports I and II. However, data relating to teacher behavior and performance at the school and classroom levels are lacking in these reports.

\section{Relevance of the Current Teacher Development System: Social Dimension of Access and Equity}

Though the relevance of the teacher development system from the perspective of the social dimensions of access and equity has been improving over the years, all existing provisions are not effectively implemented in the absence of adequate government willpower to take and implement critical decisions. The proportion of females in the teaching workforce has increased over the years, although it varies widely by levels. The Education Act and Education Regulations (2002) made the recruitment of at least one female teacher in each primary school mandatory. The provision allowing recruitment of temporary teachers at the school level further promoted participation of females in the teaching force. The Teacher Service Commission Regulations (2000) have also exempted female candidates for 2 years from the prerequisite of securing a basic teacher training certificate to obtain a teaching position. The policy could have risked quality at the expense of meeting gender targets. While the number of female teachers increased, the majority are still concentrated in the preschool and primary levels. However, this situation is expected to improve in the future, as the enrollments of female students in the preservice teacher education courses at the higher education level are very encouraging (improving from $29.7 \%$ in 2005 to $45.0 \%$ in 2010) (UGC 2013). Another issue attached to gender parity in the teaching force is movement. The available evidence showed that $84 \%$ of female teachers were serving in their own place of residence (Bista 2006) as opposed to $77 \%$ of male teachers. ${ }^{45}$ Cultural restrictions on free movement, the need to combine household work with work outside the home, and a host of other factors perhaps force women to remain in their own place of residence.

45. The policy of the government has been to post female teachers in their own place of residence or in places where their husbands are posted (in the case of married women). 
Ethnic minorities. Despite the government's efforts to promote enrollment of disadvantaged castes and ethnic minorities in the teaching force, the share of various disadvantaged groups is still low compared with that of others and their share of the population (Table A2.3). Although data by income groups are not available, economically underprivileged people are obviously less represented in the teaching profession compared to others, especially in the lower-level schools. Legislative provisions favoring employment of certain disadvantaged groups and castes in publicly funded institutions have come in force in recent years, but it is too early to look for any conclusive evidence regarding the impact of this legislation on the participation of low-income groups in the teaching service. In recent years, promotion of multilingual education and education in the mother tongue has, to some extent, necessitated hiring of local teachers and encouraged participation of local ethnic groups in the teaching force. There is a need for an education management information system (EMIS) to track teachers by mother tongue and their place of residence in addition to their caste or ethnicity.

Geographical equity. The student-teacher ratio (for general teachers) is found to vary from 13 to 70 students per teacher for two different districts. The imbalance among districts was the result of biased allocation of teacher quotas in urban areas and irrational transfer of teachers from rural to urban areas through political influence. The availability of subject teachers in rural and remote areas is still well below the demand.

\section{Organizational and Management Effectiveness of the Teacher Development System}

Under the broad legislative structure of the Education Act and the Education Regulations, NCED and the Ministry of Education (MOE) have prepared policy guidelines for providing an operational framework for implementing programs related to capacity building of the total education system, including teacher development.

Factors affecting teacher development system and teacher performance. Various factors shape the teacher development system, which ultimately affects teacher performance. Under the existing structure, the district education office (DEO) is the responsible agency for teacher management and, by implication, for teacher development as well. Experience has shown, however, that the DEO, despite being equipped with technical staff, has been more involved in distributing resources and solving school-level conflicts (often related to teachers) than in providing technical support to schools and teachers. The school supervisors who are supposed to visit the assigned schools regularly to monitor performance of schools and teachers and suggest corrective actions are currently assigned different responsibilities at the DEO. Consequently, they seldom travel to schools to provide technical support and backstopping. The resource persons have many schools to cover (up to 100 in a few cases in the terai), and they are often found in the DEOs doing administrative tasks. As a result, the mechanism to monitor and supervise teacher performance through school supervisors and resource persons remains defunct.

Institutional coordination. The core problem of teacher management relates to the confusion on the roles of the TSC, DEOs, and SMCs regarding teacher recruitment, performance evaluation, promotion, and termination of service. The Education Act, Education Regulations, and TSC guidelines are not congruent in this matter. While the Education Act gives teacher recruitment authority to SMCs, the TSC is set to recommend 
the successful candidates from the recently conducted licensing examination for permanent teacher positions. The TSC, with a reduced role in recent years, has not been able to smoothly perform the required activities related to teacher performance assessment and promotion, and appears more interested in its role in teacher recruitment. ${ }^{46}$ Despite authority to hire and fire teachers, especially in the case of community schools, the SMCs are unable to exercise it in the absence of procedural clarity and support from DEOs to implement the legal provisions. The existing arrangements for teacher development (including recruitment, performance monitoring, and promotion) are lacking in transparency, are not perfectly merit-based, and do not involve adequate accountability checks. Though there are standard procedures set by policy documents for teacher recruitment, the provisions are not strictly followed in the absence of a suitable monitoring or validating mechanism. For example, the recruitment examinations conducted by the TSC use merit as a basis for teacher selection. However, there are concerns that the meritbased list of teacher candidates provided by the TSC to DEOs and SMCs, who have been authorized to recruit teachers, may not be adequately used as the recruitment process is not transparent. There is also confusion at the district level. Even though the DOE monitors performance, ETCs will have a parallel mechanism in the absence of collaboration. Resource centers, as a body utilized by both ETCs and DEOs, have dual and often unclear reporting responsibilities.

The DOE has set up an EMIS to monitor and record school-related data on a regular basis through DEOs. Though the EMIS maintains and publishes brief information related to schools including teachers (disaggregated by sex, caste or ethnicity, etc.), the management of teacher information is not adequate with two separate agencies (i.e., the DOE and School Teacher Record Office) involved in the record keeping of schoolteachers. Lack of a proper TMIS has led to (i) miscalculation of teacher demand and supply (leading to skewed deployment of teachers); (ii) creation of khetala (contract) teachers to work on behalf of the approved teachers; (iii) recruitment of fake teachers with fake certifications, licenses, and recruitment orders from the DEO; (iv) promotion of teachers on an ad hoc basis (without following their performance profile); and ( $v$ ) inappropriate use of incentives (without any linkage to performance). ${ }^{47}$

\section{Quality of Teacher Training Programs and Delivery}

The quality of teacher training programs determines the quality of teachers. There are several factors that influence the quality of teacher training programs as discussed in the following.

Approach to delivery of curriculum. Curricula of the preservice teacher education programs are structurally loaded with adequate content, although the overall approach and delivery most often remains traditional and fairly weak. The courses of study within the curricula are academically structured in a framework consisting of objectives, content, teaching and learning methods and strategies, evaluation procedures, and a

${ }^{46}$ Verified by the fact that teacher promotions are sluggish as identified by schoolteachers, while the TSC recently conducted teacher recruitment examinations to meet the permanent teacher quota.

47 In Dhanusha, during May and June 2013, around 100 more teachers were found to have worked in schools than the actual teacher quota approved by the DEO. The extra teachers and schools utilized a fake teacher quota approval letter from the DEO and recruited fake teachers. During an investigation conducted by the DEO immediately after the incident, it was found that many teachers in the approved quota also had fake certificates and teaching licenses. 
list of references. From the perspective of structure and content, the preservice teacher education curricula are comparable with similar regional and international programs. One important reservation remains: the time factor. In Nepal, critics often attack the 3-year bachelor's program in education for its graduates' substandard mastery of subject matter as, unlike students of other faculties, they must expend time and energy in two different areas of study-content as well as pedagogy_-simultaneously within the same time period, which might adversely affect their learning in both areas. ${ }^{48}$ In addition, the course does not adequately deliver the given content nor does it provide hands-on experience with (i) development and use of teaching and learning materials and (ii) child-friendly teaching and learning processes (active learning, learning without fear, child-centered methods). Though a "teaching practice" scheme is in place, it is not only too short and lacking in technical rigor, but also is not monitored and evaluated well at the school level. Despite well-structured curricula, the prominent weakness of the program lies in its delivery. General observations in the field indicate that the preservice classes mostly follow traditional "chalk and talk" delivery and are characterized by high absenteeism of both students and teachers (Cummins et al. 2012). Even though the curricula follow a competency-based approach, the delivery and assessment mechanism does not satisfy the requirements of teacher competency. The classroom delivery and assessment of students is poor while the curriculum is good enough. It is more about administration and use of the curriculum. The training pedagogy has heavily focused on transmitting information, characteristic of the "banking" concept of education. The teacher education institutions operate in isolation from the schools and communities they serve as well as peer institutions and other institutions of higher learning. Most important of all is that practice teaching (student teaching) remains a weak link of the curriculum transaction (KUSOE 2009). There is limited knowledge on the utility of a preservice teacher education course. The preservice course acts as a separate university degree rather than a teacher preparatory course, which only involves students interested in joining the teaching force.

Training course content. While subject knowledge is the primary focus of in-service teacher training, the content for TPD training is determined based on requests collected from individual teachers. The TPD program does not have a predefined curriculum, although it does have a structure of three 10-day modules. The curricula for different groups of trainees vary, as the contents are selected only after a careful consideration of their stated needs following a given procedure. The modality of ongoing TPD training is completely different from other forms of teacher training. TPD is demand based and caters to all teachers in government-funded schools. The training providers are locally available, not uniform, and are of different quality. The training programs are not standardized and do not have adequate linkages to the overall teacher competency framework. Experiences with past and ongoing in-service training programs indicate that these have rarely led to classroom transformation. Although the 10-month modular in-service teacher training was strong in content and properly structured, the overall quality of classroom-level delivery of training was not satisfactory. Thus, it failed to make an impact inside the classroom in terms of improving student learning. The opinion of most stakeholders is that in-service programs have been reduced to training halls and leave no impact on the teachers; according to

\footnotetext{
48 Almost everywhere in the contemporary academic world, bachelor's degree-level programs are normally of 4-year duration, which give students adequate time to acquire reasonable mastery of the contents of their major subjects of study (refer to the Bologna Declaration on European Space for Higher Education; Crosier and Parveva 2013).
} 
NCED (2011), less than $50 \%$ of the training content gets translated into actual classroom teaching (Shams, Thapa, and Parajuli 2012). On the other hand, despite points to its credit as a needs-based in-service program, TPD training, as per the government policy, is provided first to the permanent teachers rather than the untrained community-funded teachers. Moreover, it has its own drawbacks because teachers generally are not in a position, without considerable support, to recognize their needs in certain critical areas of literacy enhancement, equity, or the new curriculum (Cummins et al. 2012). There is hardly any follow-up of training programs, and classroom-level mentoring and support to teachers is also nonexistent (this could have been the role of the head teachers in ideal circumstances). The teacher training is in transition in terms of structure, content, and time requirements.

Funding. Improvement of overall teacher education and training requires prioritized public funding with systematized intake of students and institutionalized elements of accountability at every level. Part of the lacuna discussed in connection with the preservice 3-year bachelor's program is expected to be addressed with universities gearing up for 4-year bachelor's programs. As far as other aspects of teacher education, including practice teaching, are concerned, improvement in overall quality demands not only increased and prioritized public spending in teacher education, it also requires a coordinated effort of all stakeholders for a well-screened intake of students with appropriate aptitude based on a planned scenario of human resources demand for development. To deliver an effective teacher education and training program aiming at professional development, there is a need to link it with the career ladder as well as to legally introduce the elements of accountability and built-in objective assessment of performance of all concerned authorities, educators, and teachers at all teacher education institutions including ETCs, resource centers, universities and colleges, and all school levels.

Research-based teacher training designs. The content of preservice and in-service education and training in pedagogy is rooted primarily on conventional domains of knowledge, which needs constant updating based on sound and systematic research in TPD. Teaching and learning on modern educational pedagogies was first initiated after the first college of education was established in 1956 with technical and financial assistance from the United States. Different in-service or preservice training programs are conducted to impart the relevant pedagogical skills to teachers. However, most updating, reorganization, and refinement of the existing pedagogies has been carried out under a broad framework of available conventional knowledge. Development of new knowledge based on objective and scientific research has been largely constrained by inadequate technical know-how and budget shortage. Although a research base is still lacking, basic groundwork on the way to this milestone is in place at the national level at the universities and other research institutions. The efforts toward building a systematic research base as a source of authentic knowledge of the relevant pedagogies need dependable and sustainable technical support.

Impact of teacher education and training in the teaching and learning process. Most of the teacher education and training initiatives have failed to transform the classroom teaching and learning process despite provision of teaching and learning materials. The use of instructional materials in classroom teaching and learning is negligible. There are a number of reasons behind their limited use. Although teachers most often report unavailability of innovative instructional materials and limited knowledge or skills to use them as key barriers 
to classroom teaching and learning, field experience shows that many teachers do not bother to adequately use even the most commonly found materials, such as textbooks, in their teaching. For instance, in a small observation conducted by a study team, only three out of 10 teachers were seen carrying textbooks with them while entering the classroom (UNICEF and RIDA 2011). The teacher education and training programs, though they prescribe the use of teaching and learning materials, do not adequately build capacity of teachers to identify, develop, and use materials. The materials prescribed during training are also not available in school. In an evaluation study of government school program (called the Quality Education Resource Package and supported by UNICEF and World Education) to use teaching and learning materials made available to schools in a tin trunk, it was found that teachers were not only unmotivated to read and use those materials in the classroom. Additionally, the materials inside the trunks (e.g., board marker, meta card, sign pen), which need to be purchased by the school to use regularly, were also not replenished (RIDA 2009). Similarly, another study of a child-friendly school program targeting elementary grades implemented by UNICEF with the Innovative Forum for Community Development showed that-despite their of their promotion of grade teaching; trained teachers specified for the target grades; well-developed and distributed materials specific to textbook contents; and material support provided to make adequate seating arrangements with wall painting, low blackboards, and so on-some schools stopped grade teaching, and the teachers became less innovative in preparing and using local-level materials on their own within a few years of the program implementation. Though the program had very good implications on student participation within the classroom, and also probably in learning, only a few schools replenished the materials. Teachers were reluctant to continue with this program in the absence of additional incentives (NEAT 2011).

Quality assurance. The quality assurance mechanisms are inadequate and nonfunctional. Though put in place to meet formal requirements, they are stagnant. As the government does not maintain performance portfolios, teachers' promotions to higher-level positions, though very rare, are carried out largely on an ad hoc basis, and are often politically influenced. ${ }^{49}$ There is no established clear performance evaluation mechanism linked with incentives, and teacher unions have also not made any advocacy for such mechanism. The performance evaluation mechanism officially in use includes many evaluation criteria while the basic criteria are of lower priority..$^{50}$ The evaluation depends largely on subjective ratings of supervisors without any real performance monitoring; in some cases, the supervisor who grades a teacher's performance does not even know the teacher. There is also a mismatch between years of experience and actual performance of the work assigned as teachers may have been assigned a nonteaching tasks. In addition, while there is no mark for attendance of teachers, marks are allotted for project work not directly related to classroom teaching and learning. In fact, performance evaluations do not really involve objective evaluation of teacher performance at the classroom level. Since the teacher promotion system is

\footnotetext{
49 Based on discussion with teachers.

50 The teacher performance evaluation form is included in the education regulations as an annex. The TSC uses the same form to collect teacher performance evaluation data. It is a four-page document to be filled in by teachers and appraised by various authorities. The form has to be completed and submitted with attachments and details every year. The form is compiled by the DEO and forwarded to the TSC. The form contains the following key sections: (i) average learning achievement of students (for grades 3, 5, and 8); (ii) action research conducted by the teacher (action research report to be attached); (iii) additional responsibility taken by the teacher, such as a sports teacher or student club coordinator; and (iv) assessment by supervisor and review committee.
} 
sluggish, the performance evaluation procedure is not functional. It is not regular and is not conducted with the required rigor in the absence of adequate prioritization and the necessary competency and skills among reviewers.

There are differences between private and public school teachers in terms of recruitment, selection, training, benefits, and career path. The quality assurance mechanism for public school teachers does not apply to private school teachers. In private schools, there are teachers without a teaching license, preservice training, or required qualifications. Private schools are yet to abide by the minimum teacher salary provisions fixed by the government. However, a general comparison of School Leaving Certificate results between private and public schools indicate that the students of poorly trained private teachers perform better than those of fully trained government teachers. In the School Leaving Certificate results published in 2015 , the pass rate for public school was only $28 \%$ compared with 93\% for private schools. ${ }^{51}$ This indicates that teacher performance inside the classroom and management of their performance makes a difference. In many cases, private schools reward teachers who produce students with good exam results.

\section{Costs, Financing, and Internal Efficiency of the Teacher Development System}

The teacher development system in Nepal faces resource shortfalls, while the budget allocated for teacher salaries is high.

Teacher development system cost and financing. The teacher development system suffers more in terms of financial inefficiency and less in terms of physical inefficiency. In the absence of good quality of preservice or in-service teacher education and training, there are various additional investments from government, nongovernment, and private sector agencies. High-quality preservice training can help the government to save money by cutting back investments in in-service education and training. As the costs and benefits of teacher education programs have rarely been examined in the past, data relating to the cost of training programs have been hard to find in this country without undertaking independent mini-studies, which was not feasible for the sake of the study under reference. However, small bits of information reported here and there in terms of the government grants disbursed to higher education, and especially for the operation of teacher education institutions, can be taken as broad indicators. For instance, a study by CEDA (2007) has reported that the annual unit cost of producing a student in Tribhuvan University (the only institution of higher learning for many years in the past and accommodating more than $85 \%$ of the higher education students at present) was NRs12,433 in FY2001 and reached to NRs15,553 in FY2004. ${ }^{52}$ In FY2011, per student spending in the constituent campuses was NRs22,045 and in community campuses only NRs1,093, making the overall net per student

\footnotetext{
51 See http://www.myrepublica.com/portal/index.php?action=news_details\&news_id=77105.

52 This per student unit cost was based on the total annual budget expenditures incurred for the students of different higher education programs including medicine, engineering, agriculture and animal husbandry, and forestry, which account for the lion's share of the total spending. An insignificant share is left for the teacher education program, which is assigned the lowest priority in the total university budget. For example, per student budget spent in the education faculty program in the school year 2004/05 was only NRs3,968 as against NRs11,783 per student budget spent on all faculty programs. When figures from the public financing of higher education for the period 2005-2010 are considered, the trend of spending appears unchanged as the per student budget spending in the higher education programs under the universities constituent campuses ranged from NRs10,198 to NRs22,045 and NRs460 to NRs1,118 in community campuses.
} 
subsidy equal to NRs12,481 in all public campuses (UGC 2012). ${ }^{53} \mathrm{~A}$ large share of the budget is spent on physical infrastructure rather than on quality enhancement programs. One indication of the national priority accorded to higher education is that it receives only $8 \%$ of the education budget, and preservice teacher education has clearly remained a neglected area in the whole education sector.

Preservice programs produce more prospective teachers every year than the number of vacant positions. Though no data are available on their internal efficiency, the preservice teacher education programs of different universities witness many dropouts and failures (in 2010/11, the bachelors' level pass rate was 30\% and the masters' level 26\%, according to the education management information system report of the University Grants Commission (2012), in large part because the preservice enrollment mostly comprises lower-achieving students. There are also fewer students in the lower secondary and secondary preservice training programs than in the primary level.

Financial efficiency of training centers. Since the completion of the Teacher Education Project, the teacher development mechanism under the government system has been running on limited resources. This resource shortage has led to fewer beneficiaries, shorter training programs, and inadequate facilities.

The workload for all ETCs is low at present, particularly because there are only a few training programs, and the budget allocated to training centers is very small. These days, the training centers do not get adequate budget to maintain and operate the available facilities. ${ }^{54}$ In a sense, the higher-level ETC facilities are underutilized whereas many lowerlevel ETCs and resource centers do not have adequate facilities. Despite enough physical facilities, albeit not adequately maintained or updated, the ETCs do not have adequate infrastructure to use information and communication technology (ICT) in delivering teacher training. Some ETCs have attempted to use computers and projectors in delivering class lectures.

\section{Information and Communications Technology to Support Teacher Development}

ICT services are increasingly used in Nepal along with expansion of internet services and mobile equipment throughout the country. According to the National Population and Housing Census 2011, there are more households with mobile phones than with toilets. The availability of computers is improving, though this technology is far from accessible to all schools. The quality and speed of internet services and its availability in rural areas are thin.

Information and communication technology in education. The government is attempting to use ICT wherever possible. However, the direction and vision are not clear. It has been more than a decade since a formal curriculum and textbooks for computer education were introduced as an optional subject in secondary education. The Government of Nepal, with support from the NGO Open Learning Exchange Nepal, initiated the One Laptop per Child program with built-in learning content customized based on curriculum and the learning

\footnotetext{
53 These figures are based only on the government's annual expenditure, and do not include out-of-pocket expenses.

${ }^{54}$ Based on discussion with trainers at ETCs.
} 
ability of primary-level students. ${ }^{55}$ Teachers were also trained on how to use laptops in classroom teaching and learning for various subjects and grades. NCED currently uses ICT for administration, communication, and monitoring purposes. The Distance and Open Learning Division of NCED, which was a separate center previously, also utilizes ICT for teacher and trainer orientation through TV and radio. The Tribhuvan University Faculty of Education offers MEd and BEd courses in ICT.

Information and communication technology in teacher education and training. There has been a gradual increase in the use of ICT in teacher training, although the availability and use of ICT-based resources for teachers remains very limited compared to the need and potential. For training programs organized in ETCs, ICT is used to deliver content through Microsoft PowerPoint presentations, videos, and other materials. ICT facilities, though not adequate in all ETCs, have helped teacher trainers to enrich their knowledge in training content and to update available information. At present, ETCs do not have enough facilities to utilize ICT, nor do the teacher trainers have adequate skills and knowledge on ICT. The training by ETCs does not involve ways to use ICT in classroom teaching and learning. Though NCED has attempted to provide online and offline interaction services to reach to trainers throughout the country, there are very few resource centers with computers, internet connections, and resource persons who can use computers. ${ }^{56}$ The universities have been attempting to use ICT in their teacher education programs as far as their resources permit. However, the use of ICT in a wide range of teacher development activities, from open and distance learning targeting larger populations of schoolteachers to using it to complement face-to-face classroom settings, as is practiced in other countries in Asia and the Pacific (UNESCO 2011), seems only a very distant reality for the time being in Nepal.

Information and communication technology-related knowledge and skills in the teacher competencies. ICT-related knowledge and skills are not yet part of teacher competencies. At the school level, school management committees (SMCs) might consider knowledge of ICT as an advantage depending on the availability of computers. Though ICT development is not linked with the teacher education system directly, the use of ICT among teachers, especially for learning purposes, is increasing. The access of teachers to ICT is better in private schools than in public schools. In private schools, the recent trend is to include knowledge of ICT as a competency criterion. The teachers explore materials and content on the internet, prepare their lessons, and deliver lessons by using computers.

Much has been explored and achieved since Nepal started its journey to modernize its education system by way of teacher development. Teaching has been recognized as a profession. A basic level of initial teacher education has been made essential to become a teacher. Efforts to systematize teacher recruitment have been initiated. The need for quality teacher education and training for better classroom performance has been recognized. However, experience over the years has shown that despite these reform initiatives, teachers' performance in the classroom has not improved.

\footnotetext{
55 Students were provided with individual laptops and were able to use them. However, a brief evaluation conducted in selected areas identified that the One Laptop per Child program did not have the expected impact on learning achievement.

56 Though official data are not available regarding how many resource centers have computers, it was observed during this study that none of the resource centers have computers, internet connections, or resource persons with the knowledge and skills to use computers.
} 


\section{G. Recommendations}

A good start toward the professional development of teachers has already been made in Nepal. However, a lot has yet to be done. The core objective of teacher professional development (TPD) in Nepal should be motivating teachers to learn, enhance their professional competency, and perform better inside the classroom. Keeping the past experiences in view, this section suggests certain priority measures as follows:

(i) Establish and operate a comprehensive teacher management information system with portfolio management of all teachers (including competency, overall performance, professional competency needs, training received, and post-training performance).

(ii) Keep teacher competency in place and updated with support mechanisms and a self-learning facility. The teacher competency standards must be updated or upgraded and teaching licenses should require renewal based on objectively verifiable criteria, which could include (i) number of times the teacher visited a resource center, (ii) number of times the teacher visited self-learning facilities such as a teacher library, (iii) teacher attendance rate (higher than $80 \%$ ), and (iv) at least one training taken or one workshop attended in a relevant area during the year. The enforcement of these competency measures should be coupled with a performance-based tenure system (removing the existing categorization of permanent, temporary, relief, and per-child fund). There may be similar options that could be explored and objectively verified for renewal of teacher licenses. To ensure that teachers in all districts have equal access to self-learning facilities and opportunities, the government should mobilize ETCs and resource centers accordingly.

(iii) Rearrange and manage teaching career paths, which enables recruitment of fresh teachers, motivates them to perform inside the classroom, and encourages them to take part in professional development. The job tenure of teachers could be shortened to around 10 years by introducing a swift career path with regular promotion ladders based on performance. The career path should be lengthened with teachers' promotion ladders based on objectively verifiable and transparent criteria. The existing short career ladder (first, second, and third class) could be expanded to 10 levels with slight increments in payment of around NRs250 to NRs1,000 per month for each higher step. The existing criteria for teacher performance evaluation could be used as a basis for promotion-related decisions.

(iv) Use a logical and performance-based incentive mechanism to replace the blanket approach to salary scale. To make teachers perform inside the classroom, the incentive mechanism should be arranged in line with their performance, subjects they teach (demand and supply of teachers), and locations where they provide services. Two steps are suggested. First, increase the teacher entry qualification to a bachelor's degree for the basic level and a master's for the secondary school level (in any relevant discipline) with additional preservice training of around 18 months. Second, provide the same base salary for basic- and secondary-level teachers. For higher-demand subjects (i.e., secondary teachers for English, mathematics, and science), the base salary 
could be slightly higher. The teacher salary should also have some differentials based on geographic location.

(v) Strengthen the preservice teacher education and training to reduce the resource burden of in-service teacher education and training. The following strategies should be pursued.

(vi) First, continue the existing preservice course, making it of 4 years' duration, with 3 years of regular campus or college-based study, and 1 year of supervised school-based internship. Such preservice should be available for specific subject specialization (i.e., English, mathematics, science, health and population, social studies) to offer admission to a limited number of students (after passing an entrance examination) in approved campuses to manage geographic distribution and quality standards. This should match the demand for teachers in specific subjects.

(vii) Second, for graduates from faculties other than education, there is a need for a preservice teacher education and training course (a 12- to 18-month teacher preparatory course), including a 6-month supervised internship.

(viii) Third, strengthen the preservice teacher training to provide hands-on skills and additional content to meet global standards. Some areas that require strengthening include development and use of teaching and learning materials; use of ICT in the teaching and learning process; use of child-friendly approaches and activities (including dance, song, games); use of critical thinking methodology (including group work, peer work, etc.); student assessments (covering the continuous assessment system); and education management information systems (EMIS) and education statistics.

(ix) Fourth, support professional quality enhancement for teacher educators such as faculties of education within universities, and other preservice training providers.

(x) Fifth, convert resource centers and ETCs to learning centers, and make ETCs autonomous to enable them to utilize the available facilities and services. $A$ resource utilization study of ETCs could help in framing strategies to make ETCs financially autonomous and active. There should be teacher libraries available in resource centers, which could continue the existing practices of organizing thematic workshops including subject-wise meetings of teachers, mobile meetings of teachers in different schools, and so on. The focus should be on making ICT-based materials available to teachers depending on their demand and interest.

(xi) Establish sound institutional arrangements for teacher performance management. There are two options in setting up institutional arrangements: creating a strong technical agency to look after the Teacher Service Commission (TSC) and School Teacher Record Office (STRO) roles; and bringing clarity to their roles by linking them with each other in setting up and utilizing a teacher management information system (TMIS), and by capacity building of the TSC and STRO on overall aspects of teacher performance management. The TSC and STRO, combined or separate, need to look after the following aspects:

(xii) First, forecast teacher demand and supply scenario, and coordinate with the Department of Education (DOE) and the Ministry of Education (MOE) in allocating teacher quota. 
(xiii) Second, conduct teacher license examinations following revisions and improvements in existing examination procedure. For example, such examinations should include practical tests, and assess the candidate's understanding of and adherence to child rights. Teacher licensing examinations should be conducted regularly and licenses should be issued (depending on teacher demand) with accreditations.

(xiv) Third, standardize the teacher and head teacher recruitment process to be conducted by SMCs at the school level. SMCs select teachers and head teachers based on a standardized process involving objectively verifiable criteria and an interview (with 30\%-40\% weightage). The district education office (DEO) needs to verify the selection file and check whether it follows standard procedure before providing approval. The DEO then should forward the file back to the SMC with approval and to the TSC for TMIS records.

(xv) Fourth, maintain TMIS for all teachers and head teachers working in schools (including teachers and head teachers in institutional schools and those funded by private sources in the community schools) in coordination with the DOE.

(xvi) Sixth, take decisions to promote teachers and head teachers based on the fulfillment of objectively verifiable criteria.

(xvii) Redefine the role of the National Center for Educational Development in teacher professional development. NCED needs to be developed as a technical agency that runs academic in-service courses and induction courses targeting education system managers; education officials including school supervisors; resource persons; and others working in curriculum development, continuous assessment, testing, evaluation, and so on. Hence, NCED needs to figure out suitable linkages with local and international universities to obtain adequate technical know-how and support. In addition, NCED could also lead or strengthen short-term issue-based training packages for in-service teachers in areas such as (i) multilingual education; (ii) use of ICT in education; (iii) creating a positive feedback cycle among teachers in school; (iv) genderfriendly and inclusive education; and ( $v$ ) healthy, safe, peaceful classroom and school.

(xviii) Competency standards and preservice training for head teachers should be separate. One strategy is to set competency of head teachers to be a master's in education with focus on educational management. Another is to arrange a separate preparation course for head teachers (for those who are interested in applying and attending the training) of around 18 months (including 12 months of course and 6 months of supervised internships). Competency standards (i.e., objectively verifiable criteria) for head teachers should be updated and renewed as needed.

(xix) A standardized process should be developed for head teacher recruitment with objectively verifiable criteria based on which an SMC can recruit a head teacher from among the applicants (which may include teachers from the same school who meet the requirements) through the approval of the DEO. 


\section{References}

Asian Development Bank (ADB). 2011. Completion Report: Secondary Education Support Project in Nepal. Kathmandu.

M. B. Bista. 2006. Status of Female Teachers in Nepal. Kathmandu: United Nations Educational, Scientific and Cultural Organization.

Central Bureau of Statistics (CBS). 2004. Nepal Living Standards Survey 2003/04, Statistical Report. Volume 1. Kathmandu.

- - 2007. Nepal Living Standards Survey 2006/07, Statistical Report. Kathmandu.

-_- 2011a. National Population and Housing Census 2011 (National Report). Kathmandu.

-_- 2011b. Nepal Living Standard Survey-III. Statistical Report. Volume 1. Kathmandu.

Centre for Economic Development and Administration (CEDA). 2007. Financing Higher Education in Nepal: Final Report. Submitted to South Asia Network of Economic Research Institutes, Pakistan Institute of Development Economics. Kathmandu: CEDA and Tribhuvan University.

D. Crosier and T. Parveva. 2013. The Bologna Process: Its Impact on Higher Education Development in Europe and Beyond. Paris: United Nations Educational, Scientific and Cultural Organisation and International Institute for Educational Planning.

Cummins et al. 2012. Mid Term Evaluation of the School Sector Reform Program. Kathmandu: Government of Nepal and Australian Aid.

Department of Education (DOE). 2007. Per Capita Funding Guidelines. Kathmandu.

-_- 2007. School Accreditation and Grant Distribution Manual, 2007. Kathmandu: DOE and Ministry of Education and Sports.

- - 2000-2011. Flash Reports (School-Level Educational Statistics of Nepal). Kathmandu.

_-_. 2012a. School Level Educational Statistics of Nepal: Consolidated Report 2011 (2068BS). Kathmandu.

- - - 2012b. Status Report-2011: School Sector Reform Program; Second Higher Education Project; Community School Capacity Development Program; Education for All Shishu Vikas Karyakram. Sanothimi: Ministry of Education.

Education Development Service Centre (EDSC). Various years. National-Level Assessment of Learning Achievement at G3, G5, G3, G5 and G8. Kathmandu.

Education Review Office (ERO). 2013. National Assessment of Grade 8 Students. Kathmandu: Ministry of Education.

Foundation for Human Development and Research Inputs and Development Action (RIDA). 2009. Improving Local Service Delivery for MDGs in Asia: Education Sector in Nepal, Country Case Study. http://regionalcentrebangkok.undp.or.th/practices/ governance/documents/NPL-Education Sector.pdf

Government of Nepal. 1990. Constitution of the Kingdom of Nepal. Kathmandu.

Kathmandu Post. 2013. <Article name>. 22 February.

Kathmandu University School of Education (KUSOE). 2009. Strengthening Teacher Training to Achieve Education for All: Reviewing Preservice Teacher Training in Nepal. Kathmandu. 
Ministry of Education (MOE). 2009. School Sector Reform Plan 2009-2015. Kathmandu.

- - . 2013. (Institutional (Private) Schools Standards and Operations Guidelines). Kathmandu.

Ministry of Education and Sports (MOES). 2003a. Education for All 2004-2009: Core Document. Kathmandu.

-_- 2003b. Education for All: National Plan of Action Nepal 2001-2015. Kathmandu: Nepal National Commission for United Nations Educational, Scientific and Cultural Organization in Nepal and MOES.

- - 2008. School Sector Reform: Core Document-Policies and Strategies. Kathmandu.

Ministry of Health and Population, New ERA, and ICF International Inc. 2012. Nepal Demographic and Health Survey 2011. Kathmandu.

Ministry of Finance (MOF). 2012a. Budget Speech FY 2011/2012. Kathmandu.

- - . 2012b. (Economic Survey FY 2011/12). Kathmandu.

- - - 2012c. Summary of Expenditure Allocation for Fiscal Year 2012 (The Red Book). Kathmandu.

Ministry of Law and Justice (MOLJ). 2001. Education Act 1971, Seventh Amendment (2001). Kathmandu.

-_- 2004a. Education Act 1971, Amendment Based on Ordinance (2004). Kathmandu.

- - - 2004b. (Education Regulations, 2059 BS [2002], Second Amendment, 2060 BS [2004]). Kathmandu.

-_- 2007. Interim Constitution of Nepal, 2063 (2007). Kathmandu.

- - 2008. Education Acts and Regulations. Kathmandu.

National Center for Educational Development (NCED). 2009. Independent Technical Review of Teacher Education Project (2002-2009): Final Report. Kathmandu: Ministry of Education.

-_- 2010a. Teacher Professional Development (TPD) Handbook 2066 BS. Bhaktapur.

-_- 2010b. Teacher Development Policy Guidelines. Kathmandu.

_-_. 2011. Teacher Development Policy Document. Kathmandu

_-_. 2012. Training for Trainers Teacher Professional Development Manual 2069 BS. Bhaktapur.

National Council on Teacher Quality. 2013. Teacher Prep Review: A Review of the Nation's Teacher Preparation Programs. www.nctq.org/teacherprep.

Nepal Evaluation and Assessment Team. 2011. Annual Evaluation of Quality Education through Disaster Resilient Schools Project. Study commissioned by Action Aid Nepal. Kathmandu.

Nepal Law Commission. 2009. (Teachers Service Commission Regulations 2057 BS [2000], Fourth Amendment, 2066 BS [2009]). www.lawcommission.com.np.

NORAD. 2009. Joint Evaluation of Education for All 2004-2009 Sector Program. Kathmandu: Cambridge Education Consultants and METECON Consultants on behalf of Norwegian Agency for Development. 
Organisation for Economic Co-operation and Development. 2011. Education at a Glance. www.oecd.org.

L. Pradhan. 2011. Distance Education in Nepal. Paper presented at the first International Technology, Education and Environment Conference organized by African Society for Scientific Research. Omoku, Nigeria.

Research Inputs and Development Action (RIDA). 2009. Evaluation of Partnership for Quality Education through Parental Participation Project. Kathmandu: RIDA and UNICEF Nepal Country Office.

F. Shams, D. Thapa, and T. Parajuli. 2013. Teacher Management and Development in Nepal: A Strategy and Policy Document. Manila: Asian Development Bank.

K. Shrestha. 2008. Teacher Development at Secondary Education in Nepal. Journal of Education and Research. 1(5):41-50. Kathmandu: Kathmandu University.

Teacher Service Commission. 2004. (Teacher Service Commission Working Procedure 2001). Kathmandu.

University Grants Commission (UGC). 2012. Education Management Information System: Report on Higher Education 2010/11 Nepal. Kathmandu.

-_- Undated. Annual Report 2067/68 (2010/11). Sanothimi, Bhaktapur.

United Nations Development Programme (UNDP). 2009. Human Development Report 2009. Overcoming Barriers: Human Mobility and Development. New York.

- - - 2010. Human Development Report. New York: United Nations Development Program with Oxford Poverty and Human Development Initiative.

United Nations Educational, Scientific and Cultural Organization (UNESCO). 2011. ICT for Higher Education: Case Studies from Asia and the Pacific. Bangkok: Asia and Pacific Regional Bureau for Education and UNESCO.

United Nations Children's Fund (UNICEF) and Research Inputs and Development Action (RIDA). 2009-2011. Analysis of the Impact of 3F Crisis on Children's Education in Nepal. Kathmandu.

University of Oxford. 2010. Country Briefing Nepal (Multidimensional Poverty Index at a Glance). http://ophi.qeh.ox.ac.uk.

E. Villegas-Reimers. 2003. Teacher Professional Development: An International Review of Literature. Paris: International Institute for Educational Planning. 


\section{APPENDIX 3: TEACHER PROFESSIONAL DEVELOPMENT IN SRI LANKA}

S ri Lanka is a multiethnic and multireligious country with a total population of about 20 million. The economy has expanded strongly during the past decade and has transitioned from a low-income country to a middle-income country. The gross domestic product (GDP) annual growth rate rose from 6\% in 2008 to around $8 \%$ in 2011. The composition of the national economy has been changing over time in favor of services and industry. While the share of the service sector in GDP remained at around at 59.5\% during 2008-2011, the share of industry rose slightly from $28.4 \%$ to $29.3 \%$ during the same period. On the other hand, the share of agriculture fell from $12.1 \%$ in 2008 to $11.2 \%$ in 2011 . Around $42 \%$ of the labor force was employed in the service sector with a further $27 \%$ employed in the industry sector and 31\% employed in the agriculture sector (Central Bank of Sri Lanka 2012).

The government's policy for national development seeks to promote equitable, broadbased economic growth through the expansion of infrastructure, rural development, and investment in human capital (Central Bank of Sri Lanka 2012). Priority areas for growth include agriculture, as well as services such as in banking, finance and insurance, telecommunications, and information and communication technology (ICT) and software development, which all require well-educated professionals, technical staff, and managers.

\section{A. Overview of the School Education Sector}

Education in Sri Lanka is state funded and offered free of charge at all levels, including the university level. Schooling is compulsory for children from 5 to 16 years of age, and the government provides free textbooks to all schoolchildren. The government gives high priority to improving the national education system in terms of access, quality, and efficiency in governance.

The general education school span is from primary to senior secondary (grades 1-13). The primary sublevel comprises grades 1-5 (ages 5-9), junior secondary comprises grades 6-9 (ages 10-13), senior secondary comprises grades 10-11 (ages 14-15), and senior secondary General Certificate of Education (GCE) level comprises grades 12 and 13 (ages 16-17). There are government-managed schools, government-assisted private schools, private schools, pirivena (Buddhist schools) schools, and international schools in the country. 


\section{Government Schools}

Government schools are classified as Type 1AB, Type 1C, Type 2, and Type 3. Schools classified as $1 A B$ have grades $1-12$ and 13 with GCE and advanced level $(A / L)$ science stream. Type $1 C$ has grades 1-12 and 13 but without the science stream. Type 2 schools have grades $1-11$, and Type 3 has grades $1-5$ only. About $72.0 \%$ of the schools are with primary and junior secondary grades. Only about $7.4 \%$ of the schools have grades 12 and 13 with the science stream (Table A3.1).

\section{Table A3.1: Sri Lanka-Government Schools \\ by Type and Functional Grade}

\begin{tabular}{|l|l|c|c|}
\hline Type of School & \multicolumn{1}{|c|}{ Grades } & $\begin{array}{c}\text { Number of } \\
\text { Schools }\end{array}$ & Percentage \\
\hline $1 \mathrm{AB}$ & $\begin{array}{l}\text { Grades up to 13 with General Certificate of } \\
\text { Education advanced level science stream }\end{array}$ & 716 & 7.4 \\
\hline $1 C$ & Grades up to 13 without the science stream & 2,027 & 20.8 \\
\hline 2 & Grades up to 11 & 4,045 & 41.6 \\
\hline 3 & Grades up to 5 (primary schools) & 2,943 & 30.2 \\
\hline Total & & 9,731 & 100.0 \\
\hline
\end{tabular}

Source: Government of Sri Lanka, Ministry of Education. www.moe.gov.lk.

The medium of instruction in government schools is either Sinhala or Tamil depending on the ethnicity of the student. Some schools teach selected subjects in English (bilingual). Sinhala is taught as the only medium in $64.9 \%$ of the schools $(6,312)$, while $28.9 \%$ of the schools $(2,808)$ have only the Tamil medium. Students in $0.4 \%$ of the schools (42) study in Sinhala, Tamil, and English. Public examinations are held at the end of grade 11 and at the end of grade 13. They are GCE (ordinary level) or GCE O/L, and GCE (advanced level) or GCE A/L. Based on the results of the GCE O/L, students are admitted to grade 12 and stream to arts, science, commerce, or technology based on performance in the relevant subjects. A technology stream was started in 2013. University admissions are decided on the results of the GCE A/L. Another examination is held nationwide at grade 5 . The objective of this examination is twofold: to provide stipends for students from economically disadvantaged families who perform well and to provide entry to better schools.

Student population varies remarkably, showing disparities in urban and rural schools. Nearly $32 \%$ of the 9,731 schools have less than 100 students, and $10 \%$ have $1,000-5,000$ students. On the other hand, $11(0.1 \%)$ have more than 5,000 students enrolled. These schools are very popular and situated in the most urban areas.

The primary grades (1-5) make up $42.4 \%$ of students. Statistics from 2011 show that only $11.6 \%$ proceed to higher education after the GCE O/L. Of the students in grades 12 and 13, $51.0 \%$ are in the arts stream, with only $26.5 \%$ in the commerce stream and $22.4 \%$ in the science stream.

Performance of the school education sector in comparison to some of the important indicators has improved over the years. Literacy increased from 87.2\% in 1994 to $96.4 \%$ in 
2011. The percentage passing the public examinations has also increased. The percentage passing GCE during the same period was $22.5 \%-60.8 \%$ for $\mathrm{O} / \mathrm{L}$ and $44.4 \%-61.7 \%$ for $\mathrm{A} / \mathrm{L}$. The number of teachers in schools increased from 187,586 to 216,281 , thereby decreasing the student-teacher ratio from 22:1 to 17:1. The percentage of those who have received secondary education has also risen from $53.6 \%$ to $75.0 \%$. Enrollment in the primary grades increased from $89.2 \%$ in 1994 to $98.3 \%$ in 2011 (Table A3.2).

\section{Table A3.2: Sri Lanka-Performance Indicators of the Education Sector (\%)}

\begin{tabular}{|l|c|c|c|}
\hline Indicator & $\begin{array}{c}1994 \\
(\%)\end{array}$ & $\begin{array}{c}2005 \\
(\%)\end{array}$ & $\begin{array}{c}2011 \\
(\%)\end{array}$ \\
\hline Literacy & 87.2 & 91.0 & 96.4 \\
\hline Percentage of passing GCE (ordinary level) & 22.5 & 49.7 & 60.8 \\
\hline Percentage of passing GCE (advanced level) & 44.4 & 59.2 & 61.7 \\
\hline Teacher-student ratio & $1: 22$ & $1: 21$ & $1: 17$ \\
\hline $\begin{array}{l}\text { Percentage of those who have received secondary } \\
\text { education out of the total population }\end{array}$ & 53.6 & 62.0 & 75.0 \\
\hline Percentage entering primary education & 89.2 & 90.2 & 98.3 \\
\hline Percentage entering secondary education & 90.6 & 97.7 & 98.0 \\
\hline $\begin{array}{l}\text { Percentage non-school-going children } \\
\text { (compared to population) }\end{array}$ & 11.0 & 8.0 & 3.0 \\
\hline Percentage of primary education dropouts & 1.52 & 0.77 & 0.23 \\
\hline
\end{tabular}

$\mathrm{GCE}=$ General Certificate of Education.

Source: Government of Sri Lanka, Ministry of Education. 2012. New Vision for Education and Milestones of Progress. Colombo.

\section{Other Schools}

Aside from the government schools, other schools-private, international, and pirivena (Buddhist schools) — cater to schoolchildren in Sri Lanka.

The private schools following the national curriculum are either government-assisted or fully private schools. They have their own management systems. The salaries of teachers of the government-assisted schools are paid by the government. Students of these schools follow the national curriculum and sit for the public examinations conducted nationally. They are provided with free textbooks and school uniforms. There are fully private schools with no administrative functions carried out by the education ministry. The number of private schools has been almost static, with 98 schools having a student population of 121,764 and a teacher cadre of 5,804 as of 2011 (MOE 2012b).

International schools, which are established under the Board of Investment, cater to expatriates as well as Sri Lankan nationals. The international schools offer foreign curricula and prepare students for overseas examinations. The Ministry of Education (MOE) has no function in their administration. Unlike government schools, the details of these schools are not available. 
Pirivena schools have a long history of educating the Buddhist clergy. They have a curriculum that is specially prepared for the clergy to master the religion, and they conduct special examinations. Some pirivena schools also have lay students, and they follow the national curriculum and appear for the common national examinations. There were 720 pirivena schools with a student enrollment of 121,764 with 6,129 teachers as of 2011.

\section{Management Structure of the Education System}

Education is a devolved service in Sri Lanka. Most of the schools are managed by the provincial councils. Each of the nine provinces of the country has a provincial council, which has a provincial education ministry and a provincial education department. The provincial education department has a dual function of attending to the activities of both the central ministry and the provincial ministry. Each province has several zonal education offices (ZEOs) that are under the provincial department of education. The number of ZEOs varies by province. There are 94 total ZEOs, each having several divisional education offices. Schools are administered directly by the ZEOs while the divisional education offices provide academic support. Under these provincial ministries and the central ministry are 9,731 government schools. The central ministry manages 342 schools ( $4 \%$ of the total government schools), which are called national schools. The rest, 9,389 schools (96\%), are managed by the nine provincial councils.

\section{Expenditure on General Education}

The expenditure on education has been increasing. In 2008, the total expenditure on general education was 84,713 million Sri Lanka rupees (SLRs), which rose to SLRs105,552 million in 2011 (Table A3.3). However, when the investment on education as a percentage of GDP and total government expenditure is compared, there has been no significant increase. In 2010, education expenditure as a percentage of GDP was 2\% (Central Bank of Sri Lanka 2010) and as a proportion of total government expenditure was 7.3\%. This is the smallest share of public investment in education among the countries in the region and other lower-middle-income countries.

Table A3.3: Sri Lanka—Total Public Expenditure on General Education

\begin{tabular}{|l|c|c|c|c|}
\hline Year & $\begin{array}{c}\text { Recurrent } \\
\text { Expenditure } \\
\text { (SLRe million) }\end{array}$ & $\begin{array}{c}\text { Capital } \\
\text { Expenditure } \\
\text { (SLRe million) }\end{array}$ & $\begin{array}{c}\text { Total Education } \\
\text { Expenditure } \\
\text { (SLRe million) }\end{array}$ & $\begin{array}{c}\text { Percentage } \\
\text { Increase }\end{array}$ \\
\hline 2008 & 76,554 & 8,159 & 84,713 & 13.7 \\
\hline 2009 & 83,448 & 7,774 & 91,191 & 7.7 \\
\hline 2010 & 88,010 & 7,477 & 95,487 & 4.7 \\
\hline 2011 & 100,174 & 5,378 & 105,552 & 10.5 \\
\hline
\end{tabular}

$\mathrm{SLRe}=$ Sri Lanka rupee.

Source: Government of Sri Lanka, Ministry of Education. 2012. New Vision for Education and Milestones of Progress. Colombo.

Various donors have contributed to the development of education of the country. The major donors have been the Asian Development Bank (ADB) and the World Bank. ADB has provided funding from the Secondary Education Modernization Project I (SEMP I) and Project II (SEMP II), and the Education for Knowledge Society Project. The World Bank, 
through the Education Sector Development Framework and Program, has funded the national, provincial, and institutional education development plans.

\section{B. Teacher Development, Recruitment, and Supply}

The education personnel in the public sector are categorized under four structured services: (i) Sri Lanka Teachers Service (SLTS), (ii) Sri Lanka Principals Service, (iii) Sri Lanka Teacher Educators Service, and (iv) Sri Lanka Education Administrative Service. All permanent teachers, principals, teacher educators, and administrative staff belong to these services, respectively. In 1995, a teacher service regulation was approved for the creation of a structured teacher service with five tiers to include all permanent teachers in government schools within a single service. This was established with the intention of regularizing the different categories of teachers with different qualifications and salary structures, and to bring about a clear promotional pathway to the upper levels.

The current SLTS has three classes and five tiers. (Class 1 has a single tier, while Classes 2 and 3 each has two tiers.) For regular promotions, teachers are required to complete a specific number of in-service seminars or retraining programs, fulfill the period of service, and pass an examination.

\section{Preservice Education and Training}

\section{a. National Colleges of Education Products}

Regular entrants to teaching who are professionally qualified are from the National Colleges of Education (NCOEs). There are 18 NCOEs providing 3-year preservice teacher education courses and awarding the national diploma in teaching certificate on successful completion of the course. Annually, about 3,000 diplomates are supplied to the system. These teachers have the basic academic qualification of GCE A/L and high scores in the examination. Entry to various courses depends on subjects offered and the GCE A/L scores (Z scores) and interview. On successful completion of the course, appointments are given to the candidates. This is the only regular annual intake of professionally qualified teachers to the system.

\section{b. Graduate Teachers}

University graduates are recruited based on the needs of the system. If there are more applicants than vacant graduate teaching positions, an entrance examination is conducted by the Department of Examinations. Considering the marks obtained, candidates with the highest marks qualify for interview and those who are finally hired are appointed centrally to national schools or assigned to provincial authorities for appointment to provincial schools. Graduates are sometimes appointed in large numbers when unemployed graduates clamor for secure employment.

\section{c. Volunteer Teachers}

Sometimes in remote schools, volunteer teachers with a minimum GCE O/L or GCE A/L qualification are temporarily hired to keep the schools minimally functioning. They are 
sometimes absorbed into the system without any professional qualification, which they could obtain later at a teacher training college (TTC).

Table A3.4 summarizes the different modes of recruitment adopted in the government schools in recruiting teachers to the system.

Table A3.4: Sri Lanka—Recruitment Methods for Entry-Level Teachers

\begin{tabular}{|c|c|c|c|c|}
\hline $\begin{array}{l}\text { Mode of } \\
\text { Recruitment }\end{array}$ & Area of Teaching & $\begin{array}{l}\text { Entry-Level } \\
\text { Qualification }\end{array}$ & Training & $\begin{array}{l}\text { Entry-Level Class } \\
\text { of SLTS }\end{array}$ \\
\hline \multirow{2}{*}{$\begin{array}{l}\text { National } \\
\text { Colleges of } \\
\text { Education } \\
\text { Diploma in } \\
\text { Teaching }\end{array}$} & $\begin{array}{l}\text { Primary } \\
\text { education }\end{array}$ & $\begin{array}{l}\text { GCE A/L with } \\
\text { high Z scores }\end{array}$ & \multirow{2}{*}{$\begin{array}{l}3 \text { years initial } \\
\text { training-2 years } \\
\text { institutional } \\
\text { and a 1-year } \\
\text { internship in a } \\
\text { school under } \\
\text { the guidance of } \\
\text { lecturers and } \\
\text { school mentors }\end{array}$} & \multirow[t]{2}{*}{ Class 3 Tier I } \\
\hline & $\begin{array}{l}\text { Subject } \\
\text { specialists for } \\
\text { secondary } \\
\text { education } \\
\text { (e.g., science } \\
\text { and } \\
\text { mathematics) }\end{array}$ & $\begin{array}{l}\text { GCE A/L with } \\
\text { high Z scores in } \\
\text { specific subject } \\
\text { combinations }\end{array}$ & & \\
\hline \multirow{2}{*}{$\begin{array}{l}\text { Direct } \\
\text { recruitment of } \\
\text { graduates }\end{array}$} & \multirow{2}{*}{$\begin{array}{l}\text { Degree subjects } \\
\text { on school } \\
\text { curriculum }\end{array}$} & Degree only & Without training & Class 3 Tier I \\
\hline & & Degree & $\begin{array}{l}\text { With } 1 \text { year } \\
\text { postgraduate } \\
\text { diploma in } \\
\text { education training }\end{array}$ & Class 2 Tier II \\
\hline $\begin{array}{l}\text { Bachelor of } \\
\text { Education }\end{array}$ & Subject specialty & $\begin{array}{l}\text { GCE A/L with } \\
\text { university entry } \\
\text { level Z score }\end{array}$ & $\begin{array}{l}\text { 4-year Master } \\
\text { of Education } \\
\text { course }\end{array}$ & Class 2 Tier II \\
\hline \multirow[t]{2}{*}{$\begin{array}{l}\text { Volunteer } \\
\text { teachers without } \\
\text { appointments to } \\
\text { teach in remote } \\
\text { schools }^{\mathrm{a}}\end{array}$} & \multirow[t]{2}{*}{$\begin{array}{l}\text { Ordinary level or } \\
\text { advanced level } \\
\text { subjects studied }\end{array}$} & $\begin{array}{l}\text { Absorbed into } \\
\text { teaching when } \\
\text { agitations are } \\
\text { made }\end{array}$ & $\begin{array}{l}\text { No professional } \\
\text { training }\end{array}$ & Class 3 Tier II \\
\hline & & & $\begin{array}{l}\text { In-service } \\
\text { training at } \\
\text { teacher training } \\
\text { colleges to } \\
\text { obtain teacher } \\
\text { training } \\
\text { certificate }\end{array}$ & Class 3 Tier I \\
\hline
\end{tabular}

$\mathrm{A} / \mathrm{L}=$ advanced level, GCE = General Certificate of Education, SLTS = Sri Lanka Teachers Service.

a This recruitment has stopped but had 6,400 teachers in 2011.

Source: Author.

2. Teacher Profile and General Statistics

A school census is conducted annually by the Policy Planning and Review Division of the MOE where school statistics are collected and published. Teacher data are also collected and used for planning and for administrative purposes. The ministry has an approved teacher cadre by subject category and language of instruction (Tamil and Sinhala) for the provinces and for the national schools (Table A3.5). The total approved cadre of teachers 
for the entire country is 197,279 while there are 219,886 appointed, an excess of 22,607.

This has a severe impact on cost-effectiveness and efficiency of the system.

Table A3.5: Sri Lanka—Approved Cadre of Teachers for Government Schools, 2013

\begin{tabular}{|l|c|c|c|}
\hline & Sinhala Medium & Tamil Medium & \multicolumn{1}{|c|}{ Total } \\
\hline Provinces & 119,588 & 45,136 & 164,724 \\
\hline National schools & 26,440 & 6,115 & 32,555 \\
\hline Total & 146,028 & 51,251 & 197,279 \\
\hline
\end{tabular}

Source: Data Management and Research Division, Sri Lanka Ministry of Education. www.moe.gov.lk.

There are 219,886 teachers in the 9,731 government schools. Of these, 157,279 teachers are females (72\%) and 62,607 are males (28\%).

About 50,090 teachers (22.8\%) of the system have a minimum professional qualification of bachelor's degree in education. The majority of the teachers, around 128,556 (58.5\%) are nongraduates with a diploma in teaching from NCOEs, or training certificates from TTCs. The rest, about 41,220 (18.8\%) have no professional qualifications (Table A3.6).

\section{Table A3.6: Sri Lanka-Teachers by Professional Qualification, 2013}

\begin{tabular}{|l|c|c|}
\hline Qualification & Number of Teachers & Percentage \\
\hline Master's and above & 2,574 & 1.2 \\
\hline Postgraduate diploma in education & 43,630 & 19.8 \\
\hline Bachelor's in education & 3,886 & 1.9 \\
\hline Diploma in English & 555 & 0.3 \\
\hline Diploma or certificate training librarian & 149 & 0.1 \\
\hline Diploma in agriculture & 720 & 0.3 \\
\hline Teacher training certificate & 92,065 & 41.9 \\
\hline National diploma in teaching & 35,067 & 16.0 \\
\hline Not professionally qualified & 41,220 & 18.8 \\
\hline Total & 219,866 & 100.0 \\
\hline
\end{tabular}

Source: Data Management and Research Division, Sri Lanka Ministry of Education. www.moe.gov.lk.

About 91,248 teachers have a university degree as their basic educational qualification, out of which 3,650 have postgraduate degrees of master's and above, while 128,638 teachers (58.5\%) are nongraduates.

Sinhala and Tamil are the two national languages used as mediums of instruction in schools. Hence, there are separate Sinhala and Tamil schools. Some offer bilingual classes where subjects may be taught in English as well. About 164,035 teachers (74.6\%) use Sinhala 
as medium of instruction in teaching, while about 52,998 (24.1\%) teachers use Tamil. Teachers who use English as medium of instruction number about 2,853 (1.3\%).

About $40.7 \%$ or 89,461 of the teachers are aged 40 and below while $50.8 \%$ or 111,649 are aged $41-55$ years. Since the retirement age is 60 years, the number of teachers who will retire within 5 years is 18,776 (8.5\%). These are the teachers who are $56-60$ years old and above. The annual average attrition based on these data is about 3,500 (Table A3.7).

\section{Table A3.7: Sri Lanka-Teachers by Age Group, 2010}

\begin{tabular}{|l|r|r|r|r|r|r|r|r|r|}
\hline Age Group & $\begin{array}{c}\text { Under } \\
21\end{array}$ & \multicolumn{1}{|c|}{$21-30$} & $31-40$ & $41-50$ & $51-55$ & $56-57$ & $58-60$ & $\begin{array}{c}\text { Over } \\
60\end{array}$ & Total \\
\hline Teachers & 1 & 22,302 & 67,158 & 81,954 & 29,695 & 9,769 & 8,990 & 17 & 219,886 \\
\hline Percentage & 0.0 & 10.1 & 30.5 & 37.3 & 13.5 & 4.4 & 4.1 & 0.0 & 100.0 \\
\hline
\end{tabular}

Sources: Data Management and Research Division. 2011; Sri Lanka Ministry of Education. www.moe.gov.lk.

Since $1 A B$ and $1 C$ schools are large and have a grade span up to 13 with streaming at advanced levels, $59.4 \%$ of teachers are teaching in 2,743 $1 \mathrm{AB}$ and $1 \mathrm{C}$ schools. Type 2 schools employ $30.5 \%$ of teachers and Type 3 schools employ $10.1 \%$ (Table A3.8).

\section{Table A3.8: Sri Lanka-Teachers by Functional Grade of School, 2010}

\begin{tabular}{|l|r|r|r|r|r|}
\hline Type of School & \multicolumn{1}{|c|}{$1 \mathrm{AB}$} & \multicolumn{1}{c|}{$1 \mathrm{C}$} & Type 2 & \multicolumn{1}{c|}{ Type 3 } & \multicolumn{1}{c|}{ Total } \\
\hline No. of schools & 716 & 2,027 & 4,045 & 2,943 & 9,731 \\
\hline Teachers & 60,247 & 70,383 & 67,071 & 22,185 & 219,886 \\
\hline Percentage & 27.4 & 32.0 & 30.5 & 10.1 & 100 \\
\hline
\end{tabular}

Sources: Data Management and Research Division. 2011; Sri Lanka Ministry of Education. www.moe.gov.lk.

\section{Demand for Teachers}

Sri Lanka has a student-teacher ratio of 17:1, which is low when compared to other countries (Bangladesh, 43:1; Nepal, 32:1; Pakistan, 40:1). Even though the country has a low student-teacher ratio there are issues in teacher recruitment and deployment. A high concentration of teachers in the urban schools and a very low teacher presence in the rural schools have brought about huge disparities. Because of this, teachers are in high demand in the rural schools. Teachers for science, mathematics, English, and information and communication technology (ICT) are in short supply.

\section{Recruitment and Promotion of Teachers}

The procedures for recruitment and promotion of teachers are stipulated in the SLTS Minute of the MOE published in the Government Gazette No. 865/3 of 3 April 1995. Prior to the establishment of the SLTS, there were many categories of teachers with varying salary structures. The SLTS was established to bring about uniformity in teacher recruitment, 
promotions, and salaries. The SLTS minute indicates clear recruitment procedures, the class to which a teacher belongs when appointed, and the promotional career pathways.

Since education management is devolved, teachers could be appointed to the provincial schools by the provincial public service commission. Only graduates could be appointed by this method. Some of the NCOE graduates are selected for national schools and the appointments are given by the central ministry. The provincial public service commissions issue the appointment letters to the new teachers with their assigned schools. If there are more applicants than positions, an examination will be held and appointments given based on the test score and an interview.

The SLTS minute has stated several preconditions to be fulfilled by teachers for promotions. A specified number of hours of training by accepted training providers, marks awarded for the number of years of service, and marks obtained in competitive examinations are considered for promotions. Class 2 Grade 1 teachers are subject to a performance review for promotion to Class 1 of the SLTS.

The SLTS minute also proposes a clear career path for teachers. Teachers of Class 3 of the SLTS can go up to Class 1 when they successfully complete their stipulated time periods and comply with the other conditions required for promotion.

The teachers can enter any of the other services in the education sector by sitting for the selection examination conducted for the Sri Lanka Education Administrative Service, Sri Lanka Principals Service, or Sri Lanka Teacher Educators Service. The first two services base their selection on the results of a competitive examination and an interview. Appointments for the Sri Lanka Teacher Educators Service are by interview for different subject areas in teacher education based on educational and professional qualifications.

\section{Teaching in Government Schools}

Teachers are appointed on a probationary basis for 3 years, like other government servants (Ministry of Public Administration 1985). Once made permanent after the probationary period, they are provided with most of the benefits enjoyed by any other government servant. When recruited, the teachers have to serve in a difficult area for a specified period, after which they can request transfer to a school of their choice. Transfers are decided by transfer boards established at the central ministry and in the provinces. The transfer boards sit regularly and decide on the transfers based on teacher requests and vacancies in the requested schools. Most teachers who serve in difficult areas request a transfer when the required period ends, mostly to urban areas and their home stations. In most cases, however, they find it difficult to get transfers since the in-demand urban schools usually do not have vacancies.

There is recognition for the service of teachers and officers in difficult areas. During interviews for promotions, marks may be awarded for services provided in difficult areas. Financial incentives were also proposed during various reforms, but were not implemented, mostly due to financial constraints.

Even though most teachers' first appointments are for schools in difficult areas, most of them do accept these appointments. The diplomates from the NCOEs who are posted to the provinces are especially appointed to remote schools. Since the NCOE courses are 
fully funded by the state, the new teachers are bonded to serve in the public sector after training. This helps keep the remote schools staffed with qualified teachers.

Graduates are recruited for special subjects such as science, mathematics, English, and ICT based on the needs of the ministry and the provinces to fill vacancies in the schools. Provinces have the option of recruiting graduates directly. Science, mathematics, English, and ICT graduates are always in short supply since those who take up appointments generally leave for better employment offered outside the teacher service.

The government schools in the country start at 7:30 a.m. and close at 1:30 p.m. Some schools start at 7:45 a.m. and close at 1:45 p.m., while others start at 8:00 a.m. and end at 2.00 p.m. There is a specified number of hours a day that classes must be conducted.

There are three academic terms for a school year, which coincide with the calendar year. All government schools have eight 40 -minute periods a day (40 per week).

A teacher is required to have a minimum of 35 periods or 20 teaching hours per week. A school's teacher cadre depends on the number of classes, grades, mediums of instruction, and academic streams of the advanced level classes. The education system has a problem with teacher deployment. Some urban schools have an excess of teachers while rural schools have shortages, even though the overall student-teacher ratio of the system is 17:1.

Syllabi and teacher instruction manuals are prepared by the National Institute of Education (NIE) and provided to teachers by the school. The teachers plan their lessons and make preparatory notes, called "lesson notes," which they teach from. Students are provided with free textbooks for all the subjects. Teachers receive assistance from the head of the school, the principal, and several deputy principals. For every subject, there is an appointed subject coordinator, and for every grade, a grade coordinator. They are mostly senior teachers of the school.

\section{Teaching in Private Schools}

Conditions of employment for teachers in the private sector are different from the government service. The salaries of teachers in government-assisted private schools are paid by the government and they are placed in the same teacher categories and grades as the teachers of the government service. They are also entitled to pensions after retirement.

Private schools and international schools are totally independent, and the individual schools have their own conditions of service and salary. The government has no control over these schools. They have their own administrative methods, appointments, and salary structure. It is difficult to make a generalization about service conditions and salary structures.

\section{Establishment of Quality Assurance Branch}

The MOE is entrusted with maintaining continuous development of the quality and standards of education in the country. ${ }^{57}$ To implement this responsibility, the Management and Quality Assurance Branch (MQAB) was established in the MOE on 15 January 2004

57 Section $2 \mathrm{~b}$ of Appendix 3 of the Constitution of the Democratic Socialist Republic of Sri Lanka. 
as a precondition for the initiation of the ADB-funded Secondary Education Modernization Project II.

The main objectives of quality assurance in the education system are to ensure quality in the general education system, schools, ZEOs, provincial departments of education, teacher education institutions, and the MOE based on predefined national standards and indicators. The MQAB provides a school educational quality index for each school and accredits those that score more than $75 \%$ for each theme; identifies standards and guidelines to evaluate educational institutions such as ZEOs, provincial departments of education, teacher education institutions, and the MOE; identifies competency-based standards for academic and nonacademic staff; and sets standards for physical resources such as buildings, furniture, equipment, and computers.

The MQAB is constantly evolving. It has developed guidelines on educational standards and external evaluation, and internal evaluation procedures have also been developed so that the schools themselves can conduct systematic internal evaluation (MQAB 2010). These guidelines are provided to schools and to divisional, zonal, provincial, and national offices to evaluate the schools.

\section{Minimum Quality Standards and Quality Monitoring}

The quality evaluation procedure for teacher education institutes under the MOE was published by the MQAB in 2013.

\section{a. Quality Development Process of School Education}

The broad overview of the MQAB activities is given in the introductory document Quality Development Process of School Education-Instructions on Internal Evaluation, published by the MOE. The process is for whole-school evaluation.

The process includes the following eight activities:

(i) identification of competencies necessary for the persons involved in academic and nonacademic activities;

(ii) determination of criteria for deciding the extent of performance of these activities;

(iii) development of evaluation procedure for assessing the existing competencies and level of standards based on the determined criteria;

(iv) organization and implementation of human resource development to bridge the gap in competencies and standards identified during evaluation;

(v) use of suitably designed tests in addition to educational qualifications to assess the intelligence of persons when recruitments are done for various posts;

(vi) appointment of selected persons after providing opportunities to develop the competencies up to the expected level;

(vii) conduct of continuous evaluations and identification of further training needs; and

(viii) proposal to provide promotions based not only on seniority but also on efficiency and competency, as well as merit. 


\section{b. Internal Evaluation}

For internal evaluation of schools and for total quality management, procedures and criteria for evaluation of competencies of principals and teachers, peer evaluation, and selfevaluation have been developed. Procedures have also been developed and prepared for student evaluation of teachers, evaluation through development discussions, and common school evaluations.

\section{c. External Evaluation}

An instruction manual has been prepared on educational standards and external evaluation procedures by the MQAB. It provides guidelines for the external evaluation of schools on the following areas:

- general management,

- physical and human resources management,

- systematic curriculum management,

- classroom evaluation,

- management of cocurricular activities,

- student performance,

- student welfare, and

- school and community activities.

External evaluation officers from divisional and ZEOs and provincial officers from different subject areas visit the schools in teams and even individually. At the end of the visit, an evaluation of the total management of the school is processed.

As for teacher performance, seven standards have been identified for curriculum management and classroom evaluation. For each standard, indicators have been prepared and used. Under each indicator, 5-7 criteria are provided. A five-point evaluation scale has been provided to evaluate each of the criteria. A separate teacher competency framework is not in place for exclusive evaluation of teacher performance.

\section{d. School Educational Quality Index}

The Annual Report on Quality Assurance in School Education published by the MQAB (2012) contains the analytical results of the internal and external evaluations of schools. About 6,150 schools were evaluated in 2011, and 4,494 in 2012. The evaluations of the schools were under the eight external evaluation areas or activities mentioned above. The ratings were converted into percentages and an index score (School Educational Quality Index or SEQI) is estimated based on the ratings in these eight areas.

The observed teacher performance is not linked to any incentive, such as a pay increase or promotion. Because of this, teachers put less priority on their performance. One of the objectives given in the introductory document of the MQAB is linking teacher performance with promotions and professional development opportunities.

Preservice teacher training in Sri Lanka is provided by universities, the NIE, the NCOEs, and TTCs. 


\section{Teacher Training Institutions and their Programs}

\section{a. Teacher Training in Universities}

Universities are governed by Universities Act No. 16 of 1978. They come under the University Grants Commission, the apex body of the university system established under the same legislation. ${ }^{58}$ The universities play a vital role in providing professional development for the country's teachers. The universities provide bachelor's degree courses in education, postgraduate diploma in education courses, and higher education degrees (Table A3.9). The duration of the programs ranges from 1 year to 4 years. Out of the 17 national universities, four-University of Colombo, University of Peradeniya, Jaffna University, and the Open University of Sri Lanka-have either a faculty or a department of education. These four universities are in Colombo District in the Western Province, Kandy District in the Central Province, and Jaffna District in the Northern Province. The Open University of Sri Lanka conducts courses using distance learning with face-toface contact sessions during the weekends in their regional centers. The university has a network of 28 centers distributed all over the country for easy access to students for their contact sessions.

\section{Table A3.9: Sri Lanka-Teacher Education Courses Conducted by Universities}

\begin{tabular}{|c|c|c|c|}
\hline University & Course & $\begin{array}{l}\text { Type of } \\
\text { Training }\end{array}$ & Duration \\
\hline \multirow{2}{*}{$\begin{array}{l}\text { University of Colombo, } \\
\text { University of Peradeniya, } \\
\text { Jaffna University, and Open } \\
\text { University of Sri Lanka }\end{array}$} & $\begin{array}{l}\text { Postgraduate Diploma in } \\
\text { Education (full-time) }\end{array}$ & In-service & 1 year \\
\hline & $\begin{array}{l}\text { Postgraduate Diploma in } \\
\text { Education (part-time) }\end{array}$ & In-service & $2-3$ years \\
\hline \multirow[t]{2}{*}{ University of Colombo } & $\begin{array}{l}\text { Diploma in Teaching of } \\
\text { English as a Second Language } \\
\text { (full-time) }\end{array}$ & In-service & 1 year \\
\hline & $\begin{array}{l}\text { Postgraduate Diploma } \\
\text { in Educational and } \\
\text { Psychological Assessment }\end{array}$ & In-service & 1 year \\
\hline Open University of Sri Lanka & $\begin{array}{l}\text { Postgraduate Diploma in } \\
\text { Special Needs Education }\end{array}$ & $\begin{array}{l}\text { Distance } \\
\text { mode }\end{array}$ & 15 months \\
\hline \multirow[t]{2}{*}{$\begin{array}{l}\text { Faculty of Education } \\
\text { University of Colombo }\end{array}$} & MEd (full-time) & $\begin{array}{l}\text { University- } \\
\text { based }\end{array}$ & 1 year \\
\hline & MEd (part-time) & $\begin{array}{l}\text { University- } \\
\text { and school- } \\
\text { based }\end{array}$ & 18 months \\
\hline \multirow[t]{2}{*}{ University of Peradeniya } & MEd (full-time) & $\begin{array}{l}\text { University- } \\
\text { based }\end{array}$ & 1 year \\
\hline & MA in Education & Institutional & 1 year \\
\hline University of Jaffna & MA in Education & Institutional & 1 year \\
\hline
\end{tabular}

58 The University Grants Commission plans for and coordinates university education, allocates funds to higher education institutions, maintains academic standards, regulates the administration of higher education institutions, and regulates the admission of students. Each university has a council and a senate as well as a board for each of the faculties that will monitor the activities of the departments. 
Table A3.9 continued

\begin{tabular}{|l|l|l|l|}
\hline \multirow{2}{*}{ University } & \multicolumn{1}{|c|}{ Course } & $\begin{array}{c}\text { Type of } \\
\text { Training }\end{array}$ & \multicolumn{1}{c|}{ Duration } \\
\hline Open University of Sri Lanka & MEd (part-time) & School-based & 18 months \\
\cline { 2 - 4 } & MA in Teacher Education & School-based & 2 years \\
\hline $\begin{array}{l}\text { University of Colombo, } \\
\text { University of Peradeniya, and } \\
\text { Open University of Sri Lanka }\end{array}$ & MPhil and PhD & & \\
\hline
\end{tabular}

MA = Master of Arts, MEd = Masters in Education, MPhil $=$ Master of Philosophy, $\mathrm{PhD}=$ Doctor of Philosophy.

Notes: Candidates for the full-time course for the postgraduate diploma in education are selected by the Ministry of Education through a competitive entrance examination. The courses are offered in Sinhala, Tamil, or English. Teachers are given leave with full pay to take these courses. Even private school teachers can apply to the universities for admission to these teacher education courses.

Source: Author's compilation.

All universities have their own criteria for the selection of academic staff and a very clear pathway for promotion of lecturers on attainment of professional qualifications. The appointments are approved by the university councils.

\section{b. National Institute of Education}

The NIE was established in 1986 under the provisions of NIE Act No. 28 of 1985. The main purpose of creating the NIE was to establish a unique institute to build the capacity of education managers, teacher educators, and teachers; design and develop school curricula; and conduct policy research on education. The NIE is the prime institute in the country responsible for providing leadership in the development of general education with quality, equity, and relevance in a pluralistic society.

The institute is mandated to design and develop curricula for general and teacher education, provide professional development for the education community, and spearhead change through research and innovation. Some of its objectives as given in the NIE Act are to provide and promote postgraduate education in several specialties of education; conduct and promote studies on the education system including its performance, goals, structures, content, and methodology and on the social, economic, and other aspects of education; initiate and promote innovative practices in the education system, including adaptation of technology for educational purposes; and provide for the development of professional and general competence of personnel in the education system.

The NIE is governed by a council that makes decisions on affairs of the institution. Its Academic Affairs Board is responsible for all academic matters of the institute. The board approves all school Syllabi and school curricula for primary and secondary schools and the curricula of the courses conducted by the NCOEs and NIE. The NIE also conducts examinations for NCOEs and for their own courses.

The courses conducted by the NIE are given in Table A3.10. Most are part-time and some are done through distance learning. Few are full-time programs. 
Table A3.10: Sri Lanka-Courses Conducted by the National Institute of Education

\begin{tabular}{|c|c|c|}
\hline Course & Type of Training & Duration \\
\hline Bachelor of Education degree & $\begin{array}{l}\text { For trained teachers in } \\
\text { the school system- } \\
\text { part-time distance } \\
\text { mode }\end{array}$ & $3-4$ years \\
\hline $\begin{array}{l}\text { Diploma in Teaching of English as a Second } \\
\text { Language }\end{array}$ & \multirow{4}{*}{$\begin{array}{l}\text { Part-time classes on } \\
\text { weekends and during } \\
\text { school vacations }\end{array}$} & \multirow{4}{*}{1 year } \\
\hline Diploma in Agriculture Education & & \\
\hline Diploma in Special Education & & \\
\hline $\begin{array}{l}\text { National Diploma in Education-Media } \\
\text { Studies }\end{array}$ & & \\
\hline Trained Teachers Certificate & $\begin{array}{l}\text { Distance mode } \\
\text { training for untrained } \\
\text { teachers of the system }\end{array}$ & 2 years \\
\hline $\begin{array}{l}\text { Additional language improvement courses } \\
\text { (Sinhala, Tamil, English) }\end{array}$ & $\begin{array}{l}\text { Modular approach } \\
\text { using audio material }\end{array}$ & 1 year \\
\hline $\begin{array}{l}\text { Certificate course for preschool teachers of } \\
\text { hearing impaired children }\end{array}$ & Part-time & 15 months \\
\hline $\begin{array}{l}\text { Diploma in Teacher Education-Primary } \\
\text { Education }\end{array}$ & Full-time & 1 year \\
\hline Master's programs & Part-time & $2-3$ years \\
\hline
\end{tabular}

Source: Author.

Admission to the NIE starts with advertisement in the daily papers calling for applications. Interviews are conducted to select the most suitable candidates. In addition to the above courses conducted for professional development, several other training programs are conducted to assist the provinces in implementing the school curricula of different subjects by training the in-service advisors on content and methodology. These advisors are practicing teachers who have been selected by the province to train other teachers.

There are fewer teachers teaching in the advanced level classes. The subject heads of the NIE make arrangements to train all teachers of these subjects so that information comes firsthand from the curriculum developers rather than having a cascade model of training delivery.

\section{c. National Colleges of Education}

The NCOEs were established under Parliamentary Act No. 30 of 1986. There are 18 NCOEs distributed throughout the country conducting courses in Sinhala, Tamil, and English. The Colleges of Education Board, which is chaired by the secretary of the MOE, has decision-making responsibility. The chief commissioner of teacher education of the MOE is the superintendent of the colleges of education. ${ }^{59}$

\footnotetext{
59 The manual for the NCOEs provides the guidelines for the colleges' administration and management. Guidelines are detailed in Strategies for Effective Management of NCOEs (Herath 1998). Self-evaluation procedures are also in place for achieving management efficiency.
} 
The NCOEs have been assigned different subject disciplines for training. There are about 23 courses conducted at the colleges in Sinhala and Tamil. The NCOE program has a major and a minor teaching specialization. Furthermore, the course curriculum as a professional component consisting of several professional subjects: elements of education, educational psychology, sociology of education, educational evaluation and measurement, and methods of teaching. The general subject area also includes first language, second national language, health and personal hygiene, physical education and sports, ICT, and life competencies.

The trainees are selected from among the candidates who have passed the GCE A/L having high Z scores in the relevant subject combinations. Annually, applications are called for in the Government Gazette and selections made after an interview. For some subjects, such as English, a selection test is conducted in addition to the minimum requirements stipulated in the Government Gazette notification.

The courses are fully funded by the government and free of charge for the participants. The duration of the course is 3 years. In the first 2 years, the trainees follow an institutional program with several weeks of teaching practice in schools. In the third year, trainees are placed in a school for the entire year and mentoring is provided by the teachers and principal of the school. During this internship year, an assigned NCOE lecturer visits the school to provide additional mentoring and assess the trainees.

Several methodologies are used for assessment and evaluation of the trainees. An internal continuous assessment is done by the staff of the NCOEs. After 2 years, the teacher must take an examination conducted by the Department of Examinations. Periodic assessments of teaching practice as well as assessments done during their placement year are considered in the overall assessment. While the NIE is responsible for the course content and the academic activities of all NCOEs, the Department of Examinations conducts the examinations for the candidates, still with assistance from the NIE. The NIE also awards the national Diploma in Teaching certificate to the graduates.

The Peradeniya NCOE, named the Centre for Excellence in English Education, is slightly different from the other NCOEs. It conducts in-service training in English for the teachers already in the system and other personnel in education. The college also implements a quota for prospective teachers for preservice training in English. Several types of English programs are conducted by the college. It conducts a 3-month certificate course in English professional skills development for educational administrators, an English language pedagogy course for teachers of English, a certificate course in general English, and an advanced course in language and pedagogy for teachers of English. All these courses are approved by the NIE Academic Affairs Board.

\section{d. Teacher Training Colleges}

Several decades back, untrained teachers were recruited first and subsequently trained. The TTCs, which were then numerous, provided this training. These programs are being phased out, and there are now only nine TTCs providing long-term in-service courses for the untrained teachers who are in the system. Untrained nongraduates are not normally recruited, except in rare and exceptional circumstances that arise due to shortage of teachers in certain areas. 
The TTCs are managed by the chief commissioner of teacher education of the MOE. The administration is done by the Teacher Education (Administration) Branch of the ministry. Each institution is headed by a principal. About 24 courses are conducted in TTCs in the Sinhala and Tamil languages. Several courses are conducted in one TTC. Upon successful completion of the course, a Trained Teacher Certificate is issued.

Courses in Tamil are conducted in four TTCs: Addalaichenai, Batticoloa, Kopay, and Kotagala. In 2012, 735 Tamil medium trainees were selected. For Sinhala medium trainees, 580 were admitted to four TTCs in 2012: Amarasooriya, Balapitiya, Giragama, and Maharagama. Unlike the other NCOEs, the Peradeniya NCOE exclusively provides inservice training for untrained teachers of English. The number of trainees admitted for 2012 was 173.

All courses have a total 2,440 hours for the 2 years. The professional subject fields have the same structure across courses and 360 hours are provided for three subjects: educational psychology; educational principles and school management; and educational measurement, evaluation, and assessment. For teaching practice, 240 hours are allocated in all courses. Primary and social science courses have slightly different time allocations for special subjects and the general subject fields. Since 2009, trainees of the TTCs have been directed to select two subjects, one for the main subject and the second as a subsidiary subject.

Advertisements are published in the Government Gazette for the few untrained nongraduates who are already in the system to apply to a TTC to get trained. The teachers are selected for these full-time training programs after an interview. During the 2-year program, teachers are provided with official duty leave at their full monthly pay.

The evaluation process at the TTCs consists of internal continuous evaluation and assessment and external evaluation. Internal continuous evaluation is done in the college at different stages during the 2-year program and proper directions are given in the TTC evaluation procedures. The external evaluation is conducted by the Department of Examinations. However, once all the untrained nongraduate teachers are trained and if no nongraduates are recruited in the future, the TTCs will become obsolete and decisions should be taken to transform these institutions to other suitable work in education.

\section{Short-Term In-Service Training Providers}

\section{a. Regional English Support Centers}

The regional English support centers (RESCs) aim to improve the quality of English teaching and learning. There are 30 RESCs scattered all over the country. As the name suggests, the centers are situated regionally and are places to study, learn, speak, and practice English. Each RESC has a steering committee to accommodate local needs. The committee comprises the zonal director of education, deputy director (education development), assistant director of education (English), assistant director of education (primary), English in-service advisors of the education office with which the center deals directly on finances, personnel from the English language teaching programs, and selected principals of schools and RESC staff. The local steering committee meets regularly to provide opportunities for consultations with all those concerned about the programs run by 
the RESC. It also coordinates local resources to support the center. Each center is managed by an RESC coordinator who is the team leader of the RESC team.

A national steering committee comprises representatives of entities associated with the program over a long period. This committee meets to coordinate the work of the RESC system at a national level and to give necessary guidance and direction. It provides a forum for all the stakeholders to discuss and evaluate the work of the RESC network.

The NIE is responsible for providing academic guidance and professional support to the RESC staff through workshops, conferences, visits, training programs, meetings, and publications. The NIE has a full-time project team leader to monitor and support the RESC network. The centers serve as the base for the implementation of national English language teaching programs developed by the ministry and the NIE as well as its own programs.

The MOE funds the centers' activities through the provincial department of education. The provincial department of education appoints the RESC staff in consultation with the NIE. Normally, the staff are selected from the cadres of experienced teachers. It is important to note that they are still counted in the number of teachers even though they are not teaching in schools while being seconded to the center. ${ }^{60}$

\section{b. Teacher Centers}

The MOE has established the teacher centers to provide training opportunities for teachers to fulfill the conditions stipulated in the SLTS minute. At least one center is in each zone for the teachers' convenience. The ministry has recognized the importance of teachers' qualitative development through the statement made by the secretary of education in the Handbook for Teacher Centres: "The interaction between the teacher and the student is the most important activity that happens in the school system. The interaction could be qualitatively enhanced by developing the teacher. Continuing teacher education provides professional inputs to teachers to make the interaction very effective and efficient." The MOE has established 104 teacher centers in the country to provide short-term in-service courses. The centers in each zone are directly managed and utilized by their ZEO, which serves as the center for in-service activities in the zone.

Several committees have been established for management and academic purposes. Each teacher center is managed by a management committee, and the chair of the management committee is the zonal director of education or the head of the ZEO (Teacher Education Division 2001). The teacher centers are affiliated with the 17 NCOEs. Each NCOE has a vice-president in charge of continuing teacher education to ensure the college's expertise is provided to the teacher centers in its zone. The vice-president is the other member of the management committee. In addition, the ZEO's involvement is essential for teacher centers since it makes decisions on inviting teachers to undergo training and approving duty leave for training courses, as well as on the funding for the courses (Teacher Education Division 2001).

\footnotetext{
60 "Seconded" means being temporarily assigned to the computer resource center while retaining a teacher position. Approximately $10 \%$ of teachers are not teaching in the classroom - they are seconded to various other duties but still counted as teachers. This distorts the aggregate student-teacher ratio.
} 
The courses and their structure are determined through analysis of the needs of the teachers. The teacher centers are expected to conduct periodic needs surveys. The ZEO's identification of training needs should take into consideration new trends and developments in education in general, and subject areas in particular, as well as the individual requirements of the teachers.

Teachers from the zone are selected based on subject specialties or on identified training needs. The teachers are provided with duty leave and sometimes provided with per diem expenses.

\section{c. Computer Resource Centers}

The computer resource centers were established after initial discussions of introducing computer education. The centers first provided training for students who sat for the GCE examinations and were awaiting results. The school curriculum did not have ICT education then. With time, the training was expanded for the teachers to use computers as a tool for teaching and learning - to promote computer-assisted learning in schools. The scope of these centers was expanded to implement computer education courses, use ICT for professional training, and provide opportunities for external institutions to gain training on ICT.

The computer resource centers are also administered by the ZEO. Each has three staff members who are teachers seconded to the center. One of them is assigned as the center manager. All of them should be proficient in ICT.

The main ICT courses at the computer resource centers are for students who are awaiting GCE examination results. The teacher training in ICT is basically ICT awareness and how to use it in teaching and learning. The training opportunities are arranged and funded by the ZEO. Each center has a computer laboratory with about 20 computers, a hall for lectures, and space to maintain a small office. Each center can train about 20 teachers at a time.

According to Circular 2005/29 issued by the MOE with the concurrence of the Treasury, the centers could charge fees for the courses. The collected fees could be deposited into the center's bank account and used according to the circular.

\section{d. Provincial Information and Communication Technology Centers}

Each of the nine provinces in Sri Lanka has one ICT center. They are directly managed by the provincial education departments. Training of teachers as well as other officers is conducted in these centers. The provincial education authority decides on the training needs of the teachers, and the trainers at the center design the program and provide the training.

\section{Public-Private Partnerships in Teacher Training}

Universities, NCOEs, teacher training colleges, and other training centers are in each province and thus spread across the country. In the ADB projects, computer learning centers were established and teacher training for ICT was conducted. Under the projects, private training providers were selected by the MOE to train teachers in ICT and computerassisted learning and teaching. Training institutions were selected considering their facilities, distribution over the country, qualifications, and experience in training staff. 
With the massive expansion (computers were provided to nearly all secondary schools), teachers had to be trained within a short period. Most of the teachers in these computer centers have been trained on International Computer Driving License, computer-assisted learning, International Pedagogical ICT Training, Intel Teach, e-Citizen, and courses provided by Microsoft and Oracle. At the end of a training period, a teacher-constructed presentation is done, and a course evaluation is expected from each of the participants.

A summary of teacher training providers is given in Table A3.11.

\section{Table A3.11: Sri Lanka-Teacher Training Providers}

\begin{tabular}{|c|c|c|}
\hline Responsibility & Teacher Training Provider & Number \\
\hline Ministry of Higher Education & $\begin{array}{l}\text { Universities-education faculties and } \\
\text { departments }\end{array}$ & 4 \\
\hline \multirow[t]{3}{*}{ Ministry of Education } & National Institute of Education & 1 \\
\hline & National Colleges of Education & 18 \\
\hline & Teacher training colleges & 9 \\
\hline \multirow{4}{*}{$\begin{array}{l}\text { Provincial departments of } \\
\text { education and zonal education } \\
\text { offices }\end{array}$} & Teacher centers & 104 \\
\hline & Regional English support centers & 30 \\
\hline & Computer resource centers & 100 \\
\hline & $\begin{array}{l}\text { Provincial information communication } \\
\text { technology centers }\end{array}$ & 9 \\
\hline Public-private partnerships & Private sector institutions & $\begin{array}{l}\text { Depends } \\
\text { on the } \\
\text { course }\end{array}$ \\
\hline
\end{tabular}

Source: Compiled by the author.

\section{E. Programs for Teacher Education Reform}

\section{Past Experiences}

There were two major completed projects that focused on teacher professional development, recruitment, and deployment. These are the Teacher Education and Teacher Deployment Project (1995-2005) and the rationalization of teacher deployment component of the Education Sector Development Framework and Program (2006-2010).

\section{a. Teacher Education and Teacher Deployment Project}

A major teacher education reform was undertaken in 1995 with the implementation of the World Bank-funded Teacher Education and Teacher Deployment Project, which had the following components: (i) rationalizing teacher deployment; (ii) rationalizing structure and organization of teacher education; (iii) updating teacher education programs; (iv) rationalizing staffing in teacher education institutions, strengthening staff development, and providing in-service training for teachers; ( $v$ ) rationalizing the number and location of teacher education institutions; (vi) strengthening teacher education and management; and (vii) supporting studies and monitoring. 
By project completion in 2005 , the implementation completion report listed the following achievements based on its objectives and targets.

(i) Rationalization of teacher deployment

- Proposed student-teacher ratio of 1:26 for the primary level was maintained and 1:22 for the secondary level with slight variations across the years.

- Teacher demand, excess, and deficit were assessed and adjustments made in provinces.

- Due to political, administrative, and financial reasons and the weak monitoring process by the MOE, the policy could not be implemented satisfactorily.

- Annual intakes by NCOEs for initial training were gazetted each year by subject disciplines and medium of instruction.

- An annual recurrent allocation of $3 \%$ and capital allocation of $1 \%$ for quality inputs were proposed, but a $1 \%$ annual increase was not possible due to financial constraints faced by the provincial education authorities.

\section{(ii) Structure and organization}

- The National Authority of Teacher Education was established in March 1999 as a semi-autonomous body under the MOE to coordinate all activities in teacher education. It was abolished in 2002.

- Restructuring of the NIE, four universities, NCOEs, and teacher centers was effectively implemented.

- School rationalization proposed could not be implemented satisfactorily due to many constraints.

(iii) Teacher education programs

- Seventeen NCOEs were established so that aspiring teachers can have 3 years of preservice training before they enter the service. Graduates of other disciplines are also recruited without preservice training. An effective preservice training on pedagogy for university graduates of other disciplines who wish to teach is yet to be established.

- NCOEs and teacher centers are conducting school-based teacher training and continuing teacher development programs (covering different subject content, methodologies, and novel pedagogical approaches). This needs further strengthening.

(iv) Staffing and staff development

- A 5-year staff development plan to achieve proposed professional development was implemented.

- A target student-teacher ratio for NCOEs was proposed but has fallen short of expectations.

\section{(v) Rationalization of institutes}

- Reduction of the number of institutions from 31 to 19 did not materialize. However, 4 universities, 17 NCOEs, and 100 teacher centers are now fully operational. 
(vi) Strengthening management of teacher education

- Unit cost mechanism proposed was not implemented.

- Recurrent and capital budget allocations for NCOEs have been made available as a separate budget item.

\section{b. Education Sector Development Framework and Program (2006-2010): Rationalization} of Teacher Deployment

Proposals for rationalization were stated in the Education Sector Development Framework and Program (2006-2010) for teacher deployment to ensure all schools are provided with the required number of teachers as estimated in the relevant circulars issued by the MOE.

The proposals were as follows:

- Schools will have a specified number of sanctioned positions and the salaries will be paid only for the teachers holding sanctioned posts. All excess teachers will have to be redeployed.

- All heads of schools must submit the formal qualifications of teachers assigned to a sanctioned post for authorization of that teacher's salary. If any misreporting occurs, the head of the school will be responsible and will result in disciplinary action.

- A teacher performance assessment system will be introduced in all schools, and annual salary increases will be linked to performance assessment and the automatic salary incremental system will cease.

- The graduates from NCOEs will be recruited to a division only, and will be appointed only if there is a vacant position for the specialized subject that the candidate has qualified for. All NCOE graduates will be waitlisted and will be considered for appointments when vacancies arise for their specialization.

- The MOE will establish an appropriate comprehensive electronic teacher database (teacher management information system) as a part of the central education management information system. It will also provide information for effective deployment options under different scenarios and future rationalization of teacher deployment.

- The MOE will initiate procedures for hiring of teachers directly to schools and develop capacity at divisional and school levels to manage direct recruitment of teachers by 2012.

- The MOE will assess the situation of the excess teachers who are not willing to be redeployed to divisions with teacher deficit and offer either (i) retraining, if below 45 years old, for nonacademic positions such as school counseling and career guidance positions at secondary schools, office staff positions at the school and zone level, or project assistants to divisional offices under new job descriptions; or (ii) other options including early retirement.

- Teachers in the deficit categories in a given province will not be authorized to be redeployed to nonteaching positions at schools unless the teacher has received specialized training and had been holding that position for over 3 years.

- University graduates will be recruited only for subjects where there is a deficit, and preference will be given to those who can teach in at least two languages, the mother tongue and English, and who have formal qualifications in ICT. 
- Schools having difficulty finding qualified teachers to teach in English at the junior or senior secondary level and having a minimum of 15 students per subject will be allowed to hire recently retired teachers who are qualified and competent to teach in English on 2-year renewable contracts; in conformity with the guidelines to be issued; and subject to approval by the MOE.

However, these proposals to rationalize teacher appointments and deployment were not considered when appointing and deploying teachers. In 2011 and 2012, 8,076 and 8,046 teachers, respectively, were recruited using the usual old process of recruitment and deployment (MOE 2012c).

Most components of the project and rationalization proposal of the Education Sector Development Framework and Program (2006-2010) are still valid and can be revisited to help guide any current initiatives to strengthen teacher education and teacher deployment. Substantial progress was made in teacher education with the implementation of the Teacher Education and Teacher Deployment Project. Teacher appointments and teacher deployment have also been comparatively improved but substantial progress is still needed to make the system more efficient and cost-effective.

\section{Current Reform Initiatives}

During the last 5 years, no overall policy reforms have been done in the education system. But several innovative changes have been implemented.

\section{a. Curricular Reforms}

According to the curricular reform cycle, school curricula are reformed every 8 years. A competency-based school curriculum was introduced in the curricular reforms initiated in 2007 in grades 6 and 10 and expanded in subsequent years for other grades. A 5E modelcomprising engagement, exploration, explanation, elaboration, and evaluation-was also introduced during this period.

The next curricular revision will be initiated in 2015, and the NIE has taken action to review the existing curriculum based on the feedback provided by teachers, student achievement, and views of stakeholders such as education leaders and parents. In the primary stage, changes will mainly be centered around improvement of learning achievement and developing the social skills of pupils. Issues and challenges as identified by the Education Sector Development Framework and Program (MOE 2013) by the subject curriculum committees are overloaded content; large textbooks for students; lack of discovery learning through practical sessions, projects, and assignments, particularly in science, commerce, and other senior secondary level subjects; lack of horizontal and vertical integration of the curriculum; lack of promotion of innovative, creative, and self-learning culture; and lack of promotion and stimulation of provision of generic or life skills. ${ }^{61}$ Further inclusive principles are suggested to be promoted so that no child is discriminated against or left behind.

\section{b. School-Based Teacher Recruitment}

School-based teacher recruitment is an appropriate strategy for the problems associated with staffing of rural schools and for deployment of teachers. This has been practiced in

\footnotetext{
${ }_{61}^{6 x a m p l e s}$ of life skills are communication, cultural tolerance, use of technology in preparing reports,
} appreciating logic, and reasoning. 
several provinces for the recruitment of teachers where there are vacancies in schools. Teachers are recruited through advertising and, if hired, must serve in that school for a specified number of years before being eligible for a transfer.

\section{c. Facilitation and School-Based Teacher Development}

The MOE promotes the concept of school-based teacher development (MOE 2013). Under this concept, teacher development takes place directly in the schools. It involves active participation of teachers and officials in the school support network, such as inservice advisors and the subject directors of the zonal and provincial offices, who work as facilitators. The facilitation activities include mentoring and facilitation of teaching and learning at the classroom level working directly with teachers.

Facilitation is a concept that was introduced under the Secondary Education Modernization Projects I and II. The objective of the projects was to transform the visiting supervisory staff from the provinces, zones, and divisions into facilitators rather than their current role as supervisors or inspectors. Facilitation could complement the instructions and guidance provided, further empowering teachers to improve their classroom practices. Classroom observations and the discussions that follow can be better done through facilitation than through top-down instruction to the teachers.

The advantages of facilitation in school-based teacher development are that it is provided in the school and helps to identify the training needs of teachers. One-on-one attention can be provided based on individual needs. Furthermore, any general staff development identified as necessary can be provided locally without the teachers traveling long distances for training.

\section{d. Teacher Transfer Policy}

The transfer policy is intended to assist with effective deployment of teachers to schools for the maximum benefit of teachers and students. It will also address the disparities among districts so that the all best teachers are not located in the center. Teaching in the same region or school continuously for a long period can cause stagnation, while transfers expose the teachers to different environments. It has been proposed that teachers be transferred on an 8-year cycle.

\section{e. Integration of School-Based Assessment with National Examinations}

School-based assessment has been implemented as a pilot project from grade 6 to grade 13, and school-based assessment grades are given separately from the national examinations with the GCE O/L and GCE A/L examination results. Attempts are being made to integrate the school-based assessment into the overall grade obtained in a subject (MOE 2012b).

\section{f. Computer-Assisted Learning}

Systematic provision of computers to schools started in 2003 under the Secondary Education Modernization Project I and continued in the second project phase and the Education for Knowledge Society project. ICT has been introduced as a subject in the GCE O/L and A/L curriculum. Computer-assisted learning was initially introduced under the Secondary Education Modernization Project I, and teachers in the secondary schools were trained to use it for teaching and learning. The software for subject units in grades 10 and 11 was prepared and is in SchoolNet for use by teachers and students. Nearly 5,000 
schools have been provided with computers. ADB-funded projects have provided teacher training packages on International Computer Driving License and computer-assisted learning (76,000 teachers), International Pedagogical ICT (12,000), Intel Teach $(30,000)$, Oracle, and Microsoft.

\section{g. Internet for Schools}

Internet access provided to the schools, called SchoolNet, was made possible by the Secondary Education Modernization Project II and continued by the Education for Knowledge Society Project. It is a wide area network currently connecting more than 1,600 schools island-wide that have computer learning centers. It connects the computer resource centers, provincial departments of education, ZEOs, provincial ICT centers, NCOEs, the NIE, and the MOE.

SchoolNet opens a wide array of opportunities to raise the quality of general education. It is expected to facilitate efficient distribution of electronic content to all participating schools. One significant new development that is expected is much-improved interaction between students and teachers from different schools. Teachers and students can exchange information among themselves to facilitate teaching and learning.

\section{h. Code of Conduct for Teachers}

A circular titled Code and System of Ethics on the Moral Conduct of Teachers has been issued by the MOE (2012a). The aim of the code of conduct is to protect the honor of teachers as members of an important profession. These could even be used with respect to promotions and for national assessment of teacher performance. Some of the aspects highlighted in the circular are the teacher as an individual, a parent, a source of knowledge, one who develops skills and attitudes, a guide and a counselor, and a professional. These could be integrated into the expected teacher competencies.

\section{F. Analysis of the Teacher Education System}

Building a high-quality education system that factors in the demands of the 21st century is a government priority. Among the Sri Lankan education stakeholders, it is widely recognized that teacher quality is crucial in the preparation of the future generation. To develop effective teacher education reform activities, it is essential to understand the present issues and challenges in the education system discussed in earlier sections. Education has become an important commodity due to globalization. The influence of ICT is also changing the nature of learning and teaching and the mode of schooling.

\section{Strengthening Development of Soft Skills}

In keeping with global trends, the Sri Lankan education system needs to give equal attention to strengthening the provision of soft skills such as communication, problem solving, and investigative abilities in addition to mastery of literacy, numeracy, and content. Despite past initiatives along this line, important elements have not penetrated the school system sufficiently because the essential shift in the quality of teachers has not been achieved. Efforts to improve teacher quality need to begin with identification of the exact requirements of the system and of the teachers. It is fundamental in quality teaching to emphasize values, skills, and knowledge. The teacher's expanded role involves paying 
attention to students' diverse learning needs amid varied learning contexts. A professional teacher acts more like a facilitator of learning than just a mere instructor inside the classroom.

\section{Professionalization of Teachers}

The professionalism of teachers should improve for future development of teaching and learning processes. At present, teachers are not considered "professionals" in Sri Lanka. Improvement of teacher quality requires new thinking on how to prepare the next generation of teachers to exhibit the professional standards required to keep pace with global trends and the qualities expected of professionals.

The professional development system should produce teachers with qualities that are expected for the profession. The concept of professionalism (NIE 2008) recognizes teachers' work being based on professional knowledge and skills with ability to use them appropriately in a variety of institutional contexts and diverse student demographics. Teachers are to use inquiry to investigate pedagogical issues and critically utilize evidencebased knowledge to inform professional practice. They accept responsibility for the academic and emotional outcomes of their students by setting realistic goals, empowering learning environments, and facilitating and guiding learners. They also collaborate with stakeholders, commit to continuous learning, and are directed toward enhancing desired student outcomes. These are broad-based concepts that teachers must internalize to become professionals. For teachers to attain these qualities, reforms are essential in initial teacher education to lay the foundation for the beginning teacher, and in continuing education to further strengthen the foundation already laid.

Periodic reforms are necessary to enable the education system to include innovative approaches for quality development. Continuing education programs could train teachers for such quality development activities. Globally, the use of ICT for teaching and learning has expanded and has been integrated into the education system in different ways. Basic aspects necessary for ICT, such as accessibility, content, connectivity, and skills development, are progressively improving in the education system in Sri Lanka.

Different modes of conducting continuing education and training programs are offered by different training providers. The MOE prioritizes school-based teacher development since it provides training at the site and on exact identified needs. Facilitation, coupled with school-based teacher development, synergizes the teacher development process, and zonal and provincial supervisory staff become facilitators instead of supervisors. Such activities need further strengthening.

Achievement of quality in schools is a much-discussed topic in the Sri Lankan education system as well as in other countries. Methods are in place for the evaluation of total quality of the schools. The most important element of this total quality aspect of the school system is the competency and performance of the teacher. A well-designed set of core competency standards could be translated to a competency framework, which is essential for the teachers to arrive at the prescribed competencies. The competency framework should be coupled with continuing education to provide the necessary guidance and skills. To meet the expectations of the system, it is also essential that teachers commit to achieving and maintaining the minimum competency standards. 
The teacher centers, regional English support centers, computer resource centers, and provincial ICT centers are distributed evenly in the country and form a network that could cater to local needs. If invigorated with the new innovative methods of continuing education, the centers could perform under the guidance of the NIE. Since teacher professional development is high on the MOE's agenda, there is a regular flow of funds, which is invariably increased to accommodate the new programs.

\section{Constraints}

Several of the most important constraints are listed below. These have effects on teacher professional development and, ultimately, in the effectiveness of teaching and learning in the schools.

\section{a. Policy Constraints}

Teacher recruitment. A National Education Commission report (2003) states that there is a severe mismatch between teacher requirement and teacher recruitment. Unemployed university graduates are recruited in large numbers when there is agitation about unemployment. At the same time, the number of teachers recruited for science, mathematics, ICT, and English falls short. The system has an excess of arts graduates while science and ICT graduates are in short supply. This mismatch between supply and demand of teachers has existed during the last few decades due to recruitment and deployment of teachers without considering the actual school-level demand.

Innovative pathways in recruitment are required to create a strong, high-quality teaching force. The entry requirements should be broadened to recruit teachers with diversified skills and capabilities. Rethinking the traditional methods of entry to teaching is vital in bringing about reforms in teaching and improving quality of teachers. This will include personal disposition and professional experience in addition to academic performance, which currently is the sole criterion for recruitment.

Recruitment to the NCOE preservice course is done though an advertisement in the Government Gazette, which includes the conditions and entry requirements. These entry requirements are on par with those for universities and maintain sufficiently high standards. Appointments are given after successful completion of the 3-year preservice course. The process of admission in the NCOEs is transparent. However, the course content and methodologies need updating and upgrading. Since the intention of the education system is to eventually have a cadre of graduate teachers, gradually upgrading the NCOEs into professional degree-awarding institutions should be considered. Therefore, a policy should be in place to slowly phase out the recruitment of nongraduate teachers and gradually upgrade teacher training institutions into professional graduate institutions.

Graduate teacher recruitments at present raise several issues:

- recruitment in large numbers without identifying the needs of the system,

- excess of teachers in some categories and shortages in some subjects,

- teachers directly recruited to teaching schools without any substantial preservice training,

- lack of assessment of ability and passion for teaching, and

- no time limits specified for fulfillment of professional qualifications. 
There should be a strong policy and strict implementation in recruiting teachers to schools based on subject requirements that teachers should be deployed to schools only after completing recognized initial professional training and preparation. Direct recruitment of GCE O/L and GCE A/L qualified persons had not been done recently. It can be assumed that it has stopped. However, there should be a concrete policy not to recruit teachers with such qualifications only.

The tstudent-teacher of Sri Lanka is 1:17. An acceptable student-teacher ratio should be decided and recruitment done based on the requirements of the schools. The ratio of 1:17 is not cost-effective as this results in wastage of government funds and valuable human resources. The teacher requirement should be based on the teacher cadre prepared by the Policy and Performance Review Branch of the central ministry for each of the provinces and the national schools.

Teacher deployment. Deployment of teachers has been a major issue in Sri Lanka. An excess of teachers in urban areas and a deficit of teachers in certain rural areas is a long-standing common phenomenon. Deployment should be based on subject-wise requirements of each school. The Ready Reckoner circular issued by the MOE provides guidance on the base requirement of each school. Teacher recruitment based on school requirements-"school-based teacher recruitment"-has been implemented in several provinces and has proved to be a satisfactory innovative practice that could be proposed for future practice since it addresses both the issues of recruitment and deployment. A strong policy that provides guidelines on deployment of teachers is needed.

Teacher professional development. Except for the NCOE diplomates, all graduates are recruited and sent directly to classrooms without professional pedagogical qualifications. Gunawardene (2005) states that it has not yet been possible to enforce the policy decision that all teachers should have preservice training or complete an initial course in teacher education before being appointed to a school. Political expediency has led to ad hoc appointments, though on a smaller scale than before. The criteria for recruitment of teachers should make professional qualification on teaching mandatory. Teacher professional development in Sri Lanka will include preservice teacher education (NCOEs), long-term initial professional teacher education (postgraduate diploma in education courses at universities and the NIE), in-service training (provided at NIE and zonal and provincial levels), and continuing teacher education programs (long-term and short-term courses after initial professional teacher education).

These activities are conducted independently by different institutions. There is no overarching national body to provide guidelines and coordinate teacher professional development activities. Courses are conducted by different institutions culminating in the same certification; hence, maintaining standards of such courses and even the equivalence of programs among providers could benefit from benchmarking minimum levels of good practices by the institutions. Some aspects that need streamlining are professional standards for initial teacher education, overlap between in-service training programs conducted by different partners, and the continuing education programs.

To bring about efficiency of the education system, a well-coordinated teacher education system is essential, which should be based on a national policy on overall teacher 
education. Opportunities to participate in teacher continuing professional development or in-service education and training throughout their careers should be an incentive for teachers to update their professional knowledge and skills. This continuing professional development must be responsive to achieving both quality and professionalism. The training should promote and encourage teachers to be reflective practitioners and learners in developing new knowledge and using it for innovative practices. The incentives for teachers for promoting such practices should also be clear and should be tied to their career advancement.

Establishment of a coordinating body to coordinate the teacher education activities of all institutions and a general policy on teacher professional development that could bring about the desired outcomes of teacher education will benefit the system.

\section{b. Standards and Quality Assurance}

Teaching standards have been developed for the Sri Lankan school system, and several other areas have been earmarked for development for quality assurance. For a teacher to be professionally developed and to continually maintain core competency, performance standards and a competency framework are required. Standards for principals of schools are also essential to assist in the maintenance of teacher competency standards. Teacher education programs are needed to continually develop and strengthen teachers based on the competency framework. The initial training is the foundation, and continuing education will strengthen their professional skills during their entire teaching career. The teacher competencies could be reformed and designed based on trends in global education.

Once qualified teachers enter the profession, continuous feedback on their performance is essential for self-reflection on their teaching and for accreditation. For the teachers to perform well, they should possess the necessary competencies. A competency framework must be developed with necessary competencies expected of a professional teacher. Teaching encompasses a broad range of skills and knowledge, which includes a deep knowledge of content and varied instructional strategies; creation of a pleasant and productive learning environment; use of relevant assessments; understanding of students and their mental growth; the ability to handle and work with diverse learners; strong communication skills; instructional planning skills; and the ability to create strong partnerships with parents, institutions, and the community.

Teacher preparation programs require continual innovation to develop a new generation of teachers with the above competencies. The teacher professional programs should be reinvigorated, address more evidence-based instruction, and be more responsive to school requirements and the needs of practicing teachers. During initial teacher education, the teachers should focus on acquiring the required competencies, and they will be strengthened further through in-service training and continuing education.

Teacher preparation programs require continual revision and innovation to develop the next generation of professional teachers. Modern global trends, methodologies, strategies, and innovative approaches should be integrated into teacher education programs. This is true both for initial teacher education and continuing education programs. 


\section{c. Initial Teacher Education}

In Sri Lanka, initial training is done after the teachers are recruited so they receive full salary during training-which technically is in-service because they are already hired.

In an exclusive study on university teacher education courses, Gunawardene (2011) observed that the curriculum and program structure of teacher education offered by universities are patterned after the postgraduate training model used in the past by universities in the United Kingdom. Although modifications have been made in the model, the traditional structure still prevails in most of the postgraduate diploma in education courses in the country. Lectures are the dominant mode of course delivery.

A frequent observation is the difficulty of transforming theory into practice. The actual time allotted for teaching experience is very limited.

A Bachelor of Education program was initiated in the universities in 1991, but De Silva (2004) observed that despite increasing program offerings, issues on quality and effectiveness have been raised. In a 2004 study on the implementation of the teacher education programs at the National Institute of Education, De Silva observed that there was a lack of clarity on the specific objectives of the NIE and its relationship to other authorities in the field of education. This is partly because the NIE was never conceived as a university or tertiary education institution or a postgraduate faculty that could provide postgraduate education in several education specializations. To address this, De Silva recommended that the NIE needs to establish and strengthen linkages and interface among the different centers, especially between the academic and professional centers, for more effective functioning of the NIE. The initial necessary step is to improve the quality of the institute staff so its degree programs can gain the same status and recognition as those offered by universities.

Based on the above observations, substantial changes could be proposed in university and NIE courses. This will include rethinking course structure, content, and delivery method. In implementing the changes, quality improvement through staff development programs targeting the revised roles and teaching strategies should be provided.

For teachers to be considered professionals, their classroom activities should reflect the characteristics below (NIE Singapore 2008). The teacher training institutions should modernize content and methodology to incorporate development of the following skills of a professional teacher:

- can use specialized knowledge and skills in different school situations and with different student strata,

- is able to adopt an inquiry orientation to investigate pedagogical issues and critically utilize such knowledge in their professional practices,

- accepts responsibility for students' academic and emotional outcomes by setting realistic goals through facilitation and learner guidance and empowerment,

- shows collaborative efforts and accepts involvement of stakeholders in education and communities so that education activities and efforts are germane to society, and

- is committed to continuing education to strengthen one's own expertise and experiences that could be directed to enhance student outcomes and thereby strengthen and exhibit professional identity. 
Preservice teacher education and training programs should be able to develop among their students the following:

(i) greater responsiveness to school and practitioner needs that are important and relevant;

(ii) close integration of academic knowledge, pedagogical skills, and practical applications;

(iii) capacity for reflective practice, critical inquiry, information literacy, and professional engagement with learning communities; and

(iv) capacity of teachers to handle issues of equity, inclusion, diversity, and social equity.

A study done on NCOEs (Jayasena 2004), commissioned by the NEC, observed that there was an acute shortage of academic and nonacademic staff in certain NCOEs. These positions were temporarily filled by visiting lecturers, the quality of whom is also questionable for lack of standards in selection. In schools, resident experienced teachers are supposed to mentor the student teachers. However, this is seldom carried out because of poor planning and supervision.

These factors must be considered when future changes are made. The internship or induction stage for the beginning teacher should include activities that promote and develop professionalism, including

(i) an initial phase of learning to teach where a process of engaging culturally in the school environment is provided and the new teacher can study the school as an organization;

(ii) support and assistance for the enhancement of teaching quality and career development;

(iii) experience with teaching conditions, the school, and the subjects assigned, and with activities of the school beyond classroom teaching; and

(iv) close involvement with all the partners of the school and community.

\section{d. Continuing Education (Continuing Professional Development)}

Preservice teacher education is not enough to provide teachers with the knowledge and skills necessary for a lifelong career in teaching. There must be a formal program for lifelong learning and professional development. The present working environment for Sri Lankan teachers is increasingly becoming complex because of the societal expectations. Moreover, students today are more knowledgeable about what they are expected to learn and are increasingly more autonomous. They take responsibility for their own learning due to intense competition to enter the universities in specialized fields. Continued learning and professional development are essential for developing a wide range of knowledge and skills that teachers will need to effectively cope with a wide range of issues in teaching, and to use innovative teaching strategies in a constantly evolving world.

\section{Key Opportunities}

There are several ongoing practices that could be improved to further strengthen teacher performance. The following are three areas out of several that could be developed with minimal effort, since they are already established and have tremendous potential to bring 
about quality improvement. Some practices have been stagnant and need stimulation to make progress.

\section{a. Improvement of National Colleges of Education}

NCOEs offer a structured professional preservice teacher education course and are the main institutions providing teachers for the education system. Nearly $16 \%$ of the teachers in the present system have been supplied by the NCOEs, while the rest of the positions are filled by graduate and trained teachers.

There are many strengths in this system:

(i) Prospective teachers are recruited immediately after the GCE A/L examination. These individuals have performed well on the examination and have qualifications to enter a university.

(ii) They are selected on a competitive basis considering their performance.

(iii) All recruits are young-in their early 20 s.

(iv) NCOEs offer a direct transition from school to teacher training.

The following could be done to strengthen NCOEs:

(i) Update and expand subject content.

(ii) Provide opportunities for higher-order thinking skills.

(iii) Make interactions with students less didactic and provide opportunities for students to get involved in activities in the psychomotor and affective areas.

(iv) Improve facilitation skills.

(v) Improve teacher professional skills.

(vi) Provide guidance for improving the intern's leadership role during the internship period.

(vii) Integrate innovative approaches used in the school system, such as school-based assessment, computer-assisted learning, facilitation, school-based teacher development, etc.

To achieve the above, a detailed study should be undertaken on the program to identify gaps and other areas for improvement. At present, the final certification is the national Diploma in Education. This program could be strengthened in stages by making it a degreeawarding course culminating in a Bachelor of Education degree. In this case, the program could be extended by another year, which would assist in

(i) providing more subject content, thereby expanding the scope of the teacher to work with either junior secondary or senior secondary students;

(ii) improving the pedagogical aspects, with more hands-on experience in using higher-order thinking skills as well as psychomotor and affective skills;

(iii) providing a strong ICT component, which could give teachers confidence in using ICT as a teaching tool, and provide guidance on how students can use it as a learning tool; and

(iv) providing competence in preparing and using computer-assisted learning materials. 
Eighteen NCOEs could be made the prime supplier of quality graduate teachers to the system by phased expansion of the courses to degree status and by improving the course content and its structure.

\section{b. Facilitation for School-Based Teacher Development}

In Sri Lanka, different people and organizations are involved in building teacher capacity. The NIE is a major contributor, along with provincial and zonal officers such as in-service advisors and directors. Although there are huge variations, each zone has approximately 20 in-service advisors, with at least one for each subject. In total, there are approximately 4,000 in-service advisors across Sri Lanka. The role of these advisors and the subject directors is to provide professional support for teachers in terms of training. Traditionally, teacher professional development programs in Sri Lanka were instructor directed and concentrated on dissemination of information. In more recent times, there has been some shift toward teachers participating more actively in their learning.

The typical model for professional development in Sri Lanka is the cascade model, whereby a master trainer is trained, who then trains other officers, who then train others, who finally train the teachers. Teachers express dissatisfaction with this model, feeling that all teachers should participate in quality professional learning programs that have not been diluted down the line. Similarly, concerns have been raised in the Education Sector Development Framework and Program regarding the impact of continuing and in-service education delivered through the cascade model. The model has major limitations, among them that the message tends to get weakened or distorted in transmission.

Building teacher capacity in Sri Lanka uses different but interrelated professional development activities such as workshops, courses, seminars, and so on. It is believed that training should not be limited to taking courses, which limits learning to theory and knowledge; a competency-based approach whereby staff learn to teach effectively within the school has far greater utility. For this to take place, school activities that can be used as training opportunities must be identified. Effective professional development requires highly personalized professional learning. A program was initiated in the ADB-funded Secondary Education Modernization Project II to professionally support teachers in the school setting through facilitation of learning as opposed to top-down instruction.

Professional development activities carried out by facilitators has the following strengths:

(i) continuous connected process rather than an isolated activity,

(ii) conducted at the work site (the school),

(iii) collaborative process rather than an individual activity,

(iv) identifies the strengths of the teacher,

(v) based on identified needs of the teacher,

(vi) follow-up support to continue strengthening skills,

(vii) observes the lapses of training and implementation, and

(viii)has a sound method of monitoring.

Zonal facilitators will follow up on teacher training in the schools. Facilitators will assist teachers to implement what they have learned-for example, school-based assessment, 
$I C T$, teaching and learning methodologies, and preparation and use of teaching and learning materials. The focus of programs tends to be content knowledge, teaching and learning, use of ICT, and assessment strategies. The facilitators could also provide important missing elements observed in earlier training methods-helping teachers apply what they have learned to the classroom situation, and the follow-up opportunity to assess their impact on student outcomes.

The facilitators get professional training on developing, implementing, and delivering effective teacher capacity-building programs that use a facilitation approach rather than outright delivery of content.

Facilitation assists in monitoring as well. Monitoring of teacher performance is conducted both internally and externally, typically using a top-down supervision model:

(i) Internal supervision is conducted by the supervisory staff of the school through classroom observation, self-evaluation and peer evaluation, and discussions that follow the supervision process. However, internal supervision is often neither efficient nor effective, with principals' administrative duties often leaving little time for supervision.

(ii) External supervision is conducted by education personnel in divisional, zonal, and provincial offices, and the Ministry of Education (MOE) who make periodic visits to schools, either alone or as a team.

In more recent times, for some educational programs, the trend has shifted from supervision toward facilitation. In the facilitation program, which was introduced in approximately 2007, the facilitator (usually an in-service advisor or a district director but sometimes the principal or other school officer) works with individual teachers or small groups of teachers to support and mentor them in implementation of their programs. Usually the facilitation is in relation to a special aspect of teachers' work such as school-based assessment, teaching and learning methodologies, and so on. Facilitation is considered better than supervision as this process is one of support, mentoring, understanding, and guidance where the facilitator becomes familiar with the teachers and can help them self-reflect and develop their own solutions for addressing any issues they may be facing. The facilitator is expected to visit the school and provide facilitation at regular intervals. A facilitation training package was developed in 2007 for four selected areas: school-based assessment, ICT, programs for school improvement, and teaching and learning methodologies.

Facilitators typically belong to different subject disciplines. This provides a solid base for training as it is recognized that subject experts are often best placed to deliver professional learning programs, especially at middle and higher levels.

The role of subject directors and in-service advisors in school-based teacher development has changed from supervisors to facilitators, which puts the teacher and the facilitator at the same level. This brings the in-service advisors and the subject directors closer to teachers, which encourages collaboration. Such a change has occurred to a certain extent in the system but can be developed further. 
A facilitation-based professional development program will need the following:

- preparation of revised guidelines or a handbook for effective teacher capacity building to complement the facilitation and school-based teacher development program, with copies distributed to all ministry, provincial, and zonal directors of education; NIE staff; and in-service advisors; and

- rigorous training in facilitation techniques that can be used during their visits to schools.

\section{c. Computer-Assisted Teaching and Learning}

The quality of teachers and teaching could be improved using digital content and training the teachers to use the material in their teaching (Table A3.12). ADB-funded Secondary Education Modernization Projects I and II made initial steps in the introduction of ICT in the school system. Since then, ICT use in schools has expanded, and ICT proficiency can now be considered one of the basic Sri Lankan education competencies. It is recognized as an important tool in education for investigating, creating, and presenting information by both teacher and students, regardless of the subject area. Many students use various digital tools in their everyday lives. In some cases, this contrasts strongly with the school environment, which may lack computers and other modern digital equipment. Even though some teachers are trained in ICT, others lack the confidence and expertise to use it.

In Sri Lanka, there are some initiatives related to the use of ICT, but some are in the early stages of development. Sri Lanka launched SchoolNet in 2006 with assistance from ADB. SchoolNet in Sri Lanka is a national initiative with strategic intentions to increase ICT adoption and to facilitate internet access to schools. It was established with a view to enhancing access to information, facilitating communication, and assisting in adopting innovative pedagogical approaches to using ICT for learning. About 2,500 secondary schools have computer labs, and about 4,000 schools have basic ICT facilities. A number of ICT-related professional development initiatives have been implemented-for example, the International Computer Driving License, the International Pedagogical ICT program, and Intel.

It has been observed that computers could be used for teaching and learning. For this, a system is needed with the following four basic components: (i) facilities for accessibilityprovision of laboratories, computers, and printers; (ii) connectivity-wired, wireless, and SchoolNet; (iii) skills development—providing different types of training; and (iv) content-compact discs, websites, e-mails, web pages. These important elements have been established in most of the country's secondary schools, but they need additional strengthening and provision across all the schools.

The importance of ICT across the school curriculum needs to be emphasized. It provides opportunities for blended learning. One of the strategies of the Education Sector Development Framework and Program is to develop ICT as a tool in education. If ICT is to be used as a teaching and learning tool, more support is needed in several interrelated areas, including (i) develop subject curricula and teacher instruction manuals integrating ICT activities; (ii) prepare software to be used in schools based on ICT activities given in teacher instruction manuals; (iii) prepare special instructions for teachers and students on how to use and when to use the software; (iv) host the software and instructions on 
SchoolNet; (v) provide software on compact discs as a supplement; and (vi) train teachers on the usage of the software.

\section{Table A3.12: Sri Lanka-Summary of Needs and Gaps in Computer-Assisted Teaching and Learning}

\begin{tabular}{|l|l|}
\hline \multicolumn{1}{|c|}{ Available } & \multicolumn{1}{c|}{ Gaps to Be Filled } \\
\hline Subject curricula and TIMs & Integrate ICT activities into curricula and TIMs \\
\hline $\begin{array}{l}\text { Software available for some subjects and units } \\
\text { prepared under SEMP II }\end{array}$ & $\begin{array}{l}\text { Identify exact areas that need ICT support and } \\
\text { arrange for development }\end{array}$ \\
\hline No instructions available for software & $\begin{array}{l}\text { Prepare suitable instructional material for } \\
\text { teachers and students on usage of software }\end{array}$ \\
\hline $\begin{array}{l}\text { Some software programs have been uploaded } \\
\text { to SchoolNet }\end{array}$ & $\begin{array}{l}\text { Upload all software so that students and } \\
\text { teachers can use them during and after school }\end{array}$ \\
\hline $\begin{array}{l}\text { Compact discs provided to schools on some } \\
\text { teaching and learning material }\end{array}$ & $\begin{array}{l}\text { Put the syllabi and different subject curricula } \\
\text { on compact discs so students and teachers can } \\
\text { use them offline }\end{array}$ \\
\hline $\begin{array}{l}\text { Teachers are computer-literate and are trained } \\
\text { on computer skills by International Computer } \\
\text { Driving License, International Pedagogical ICT, } \\
\text { and Intel. }\end{array}$ & $\begin{array}{l}\text { Provide training in the use of the prepared } \\
\text { software and strengthen programs for teachers } \\
\text { to develop and use computer-prepared } \\
\text { teaching material }\end{array}$ \\
\hline
\end{tabular}

$I C T=$ information and communication technology, SEMP = Secondary Education Modernization Project, TIM = teacher instruction manual.

Source: Author.

(i) Preparation of teacher instruction manuals. When preparing teacher instruction manuals, integrating ICT across the curriculum can be systematically designed. The syllabi, particularly the teacher instruction manuals, need to place greater emphasis on the skills to be developed and the integration of ICT at various progression stages; for example, clarify the skills needed in each grade level, such as what is expected differently of a student in grade 7 compared to grade 9 when they investigate (or engage in any other skill). Teachers should be guided on to how to develop students' process skills, and how to integrate ICT skills and activities with the subject knowledge. Learning experiences and assessment tasks that use ICT should be provided.

(ii) Preparation of software for subject integration. Some software programs have been prepared for several subjects and if appropriate could be used for the present curriculum. Exact areas where computer-assisted teaching and learning is required will be decided by the curriculum specialists. It is not necessary to develop ICT material for every aspect of the curricula. ICT integration should be selectively done to maximize learning outcomes.

(iii) Preparation of special instructions for teachers and students on how and when to use the software. In newly introduced activities, it is essential that the teachers receive thorough orientation and training to optimize use of the material. A generic handbook on the integration of ICT into teaching and learning is to be developed, printed, and distributed at training sessions and through other effective channels. 
(iv) Host software and instructions in SchoolNet. Most schools use SchoolNet, and they have used this service to host their web pages. The teachers and students can use the software when desired-during school hours, after school, and even weekends.

\section{d. Strengthening Information and Communication Technology Competence of Teachers across the System}

Teachers above 40 years of age make up 59.3\% of the total. These teachers generally had no ICT component in their initial teacher education programs, and hence capacity building should go beyond the ability to use ICT or be "computer literate." The real power of ICT is to enable principals, teachers, and students to use ICT in their own processes of administration, teaching, and learning. Teachers need skills to enable students to use a wide range of technologies effectively and appropriately to access, create, and communicate information and ideas; solve problems; and work collaboratively. To participate in a knowledge-based economy and to be empowered within a technologically sophisticated society now and into the future, students need the knowledge, skills, and confidence to use ICT.

Teacher capacity in ICT should be developed to be used across the school curriculum. Even though some think that ICT is more suitable for subjects such as mathematics and science than for other subject areas, that is not the case. Those countries achieving high education outcomes stress the need for all subject areas to use ICT to engage students in learning. There are numerous software programs readily available for use by both teachers and students, with many supporting interactive, student-centered learning experiences in the websites. Under the Secondary Education Modernization Project II, software was prepared for a few core subjects based on the original course units. There are other curriculumbased software provided to the school system due to public-private partnerships between the MOE and Intel, Mobitel, Skoool, and Vidunena.

\section{e. South Asian Centre for Teacher Development-Category II UNESCO Center} Teacher professional development remains the strategic priority of the South Asian countries for the achievement of high-quality teaching, which is the key component of quality education. The competency levels of teachers are often insufficient since not enough emphasis is being placed on innovative teaching methods, modern approaches, and adequate monitoring and evaluation. There is little scope for continuous skills updates of the teacher educators, counselors, mentors, and advisors. The United Nations Educational, Scientific and Cultural Organization (UNESCO) South Asian Centre for Teacher Development in Sri Lanka was established to provide institutional leadership to enhance the transformation in teacher professional development in South Asia. The center is intended to advocate for the transformation of teacher professional development, emphasizing development of innovative approaches as well as research and information sharing, with the mandate encompassing Afghanistan, Bhutan, India, Maldives, Nepal, Pakistan, and Sri Lanka.

The center addresses the gaps in professional development of teacher educators, teacher counselors, teacher advisors, and teacher mentors with the objective of providing continuing professional development of teacher educators. The center provides professional development in the areas of curriculum development, and undertakes research 
and development to bring innovation and best practices in teacher education into the country. It specifically provides capacity in the areas of ICT competency, e-pedagogy to enable teachers to incorporate electronic resources into delivery of curriculum, and development of e-courses for continuing professional development. Other aspects that will be addressed by the center will be promotion of education for peace, reconciliation, and sustainability within the South Asia region.

\section{G. Recommendations}

The most important interaction in the schools takes place between the teacher and the student; hence, strengthening teacher performance in the school is of high priority. The quality of the teachers recruited, the initial and continuing education they receive, and targets provided in the form of expected performance standards are integral components to achieving quality in teaching and learning. There are many opportunities that could be provided to teachers for professional development. Based on several identified challenges in teacher professional development, the following recommendations are presented.

A result of a teacher's professionalism is obtaining quality learning outcomes from students, which should be the ultimate goal of a good education system. Teacher professional development should focus on meeting the expectations of teachers, overcoming constraints in developing and strengthening their professionalism, and harnessing better results from key opportunities available in the system. The interrelation of aspects is summarized in Figure A3.1.

\section{Policy Recommendations}

Strong, well-defined policies are essential for systematizing the processes in teacher recruitment and deployment and for achieving an all-graduate teacher cadre. Policies are essential to overcome the piecemeal nature of initial and continuing teacher education by establishing an overarching body for the coordination of teacher education. The following are some specific policy recommendations:

(i) Teachers should be recruited after completing a professional preservice teacher education program, and not the other way around.

(ii) To make the system more cost-effective and efficient, only the number of teachers required for different subject disciplines should be recruited based on the requirements of each province and of national schools.

(iii) Deployment of teachers should be based on the cadre requirements of each school.

(iv) A policy should be prepared for the overall coordination of teacher education institutions and their programs, since a well-coordinated system is needed to bring about the professionalism expected from teachers.

(v) A time-bound policy framework should be established for the attainment of an all-graduate teacher cadre.

(vi) A coordinating body should be established for the coordination of all teacher education institutions and activities. 


\section{Figure A3.1: Sri Lanka-Conceptual Framework for Teacher Professional Development}

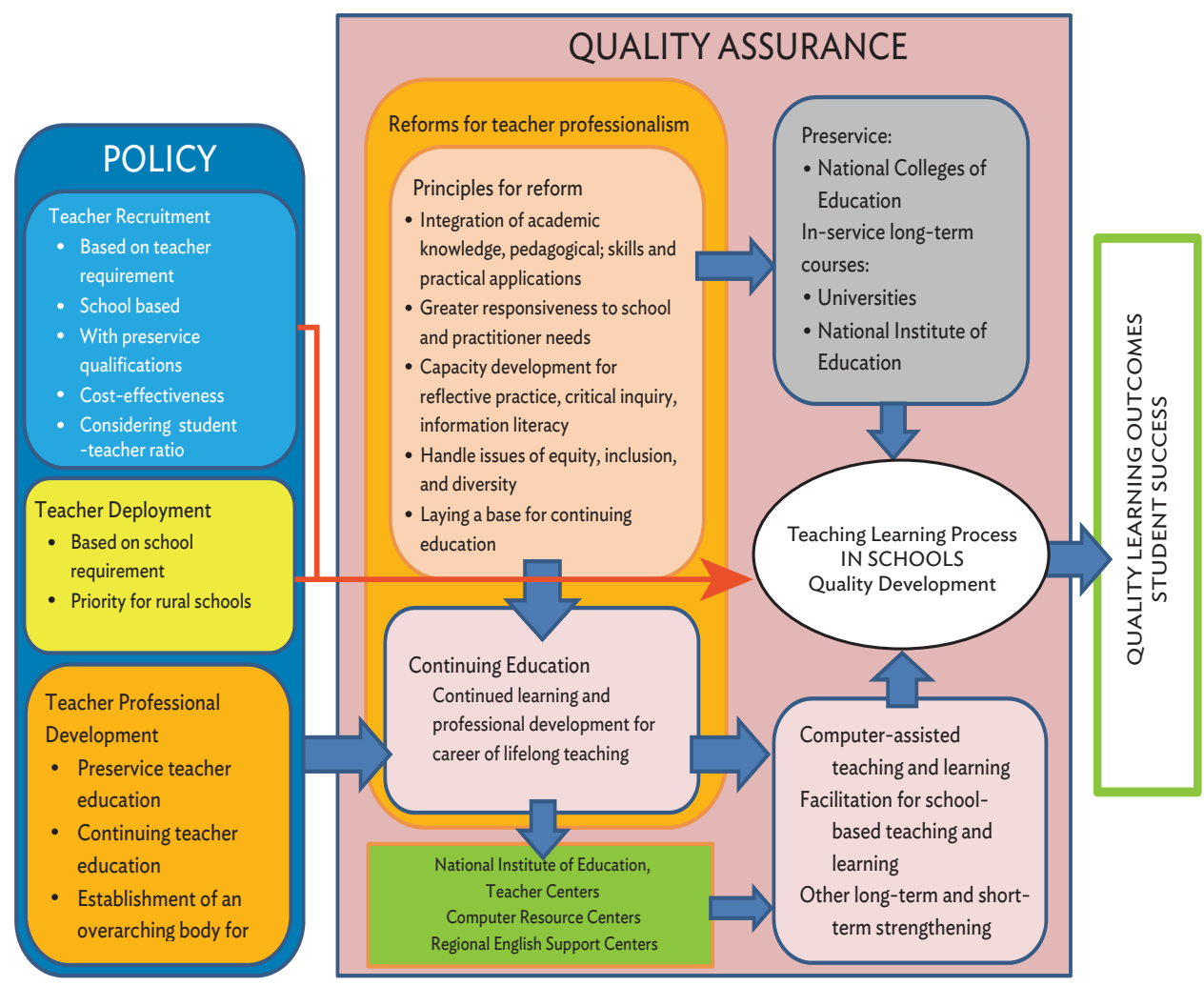

Source: Author.

\section{Standards and Quality Assurance}

The teacher is a key actor in the education process and expected standards should be clearly stated. Development of core teacher competency standards and a competency framework could motivate teachers to develop and use the necessary competencies in the schools. This will also assist in collecting information on a teacher's progress, strengths, and weaknesses, which can be used in planning continuing education programs for professional development. The teacher education institutions could assist the teachers in progressively improving their competencies. The following actions are recommended:

(i) Prepare and enforce standards for teacher education institutes and their programs to assure quality in teacher education.

(ii) Develop standards for core teacher competencies and translate them into a teacher competency framework. This will serve as a guide in designing capacity building programs and preparing training material.

(iii) Revise the Colleges of Education Act to include all institutions providing teacher education and to monitor maintenance of quality assurance standards. 


\section{Teacher Education Institutions}

An assessment of teacher education institutions or their programs has not taken place during the last decade. The time has come for an assessment to be conducted and for suitable reforms in teacher education to be approached systematically rather than as a series of fragmented activities. Modernizing the teacher education programs would improve teachers' performance, professionalism, and ability to produce students with 21st century skills. The approach should include universities, NCOEs, the NIE, teacher centers, regional English support centers, computer resource centers, and provincial ICT centers. Recommendations include the following:

(i) Assess the present status, roles, and functions of all teacher education institutions and obtain recommendations for their improvement.

(ii) Rationalize the institutions providing teacher development programs.

(iii) Explore specialist opportunities such as teacher training for the recently introduced technology stream in the secondary system.

(iv) Develop NCOEs into 4-year professional degree-awarding institutions to enable the graduates to teach up to grade 13.

\section{Reforms for Teacher Professionalism}

The most important aspect of teacher education is the professional development of the teacher. Teacher preparation programs should be revised continuously to keep teachers abreast of new approaches and trends in education and training. Teacher education programs should include global trends, methodologies, strategies, and innovative approaches suitable for the 21 st century. Central to this is to shift the teacher from being teacher centered to learner centered. This is true both for initial teacher education and continuing education programs.

All teacher education programs should be reviewed and reformed to bring about changes that align the Sri Lankan teacher with 21st century skills and professionalism.

\section{Continuing Education}

Many continuing education programs are conducted to respond to needs arising in the system. There are many skills that teachers need to support innovations in education. ICT, which has been introduced recently, is new to many teachers and training is required. While progress in ICT in education is happening in the country, it needs further strengthening. It is also identified as a key opportunity to enhance access to and quality of education.

Another key opportunity is facilitation to support school-based teacher development. Training has been conducted to change the role of officers of zones and provinces from supervisors to facilitators. This proved to be satisfactory and needs further strengthening.

The following areas in continuing education should be given priority.

\section{a. Computer-Assisted Teaching and Learning}

(i) Provide teachers with necessary ICT skills.

(ii) Conduct awareness programs on digital teaching materials available in the system and how to make use of them in teaching. 
(iii) Train teachers to integrate ICT activities provided in teaching as provided in the teacher instruction manuals.

(iv) Train teachers to prepare software for selected subject areas to facilitate teaching.

\section{b. Facilitation for School-Based Teacher Development}

- Prepare a comprehensive facilitation manual as a guide for directors and in-service advisors containing aspects of facilitation and areas such as ICT integration, school-based assessment, teaching and learning methodologies, and teaching material preparation.

- Train all directors and in-service advisors to transform them into facilitators from their present role of supervisors.

- Prepare a program for the facilitators to periodically visit schools and a program for monitoring of the activities.

c. South Asian Centre for Teacher Development-Category II UNESCO Center

(i) Provide adequate technical support of international caliber to South Asian countries in teacher professional development, as well as in the areas of curriculum development and institutional leadership.

(ii) Provide assistance in the development of ICT and e-pedagogy and e-learning exercises for the proposed areas.

(iii) Provide assistance in infrastructure and facility development. 


\section{References}

Asian Development Bank (ADB). 2009. Secondary Education Modernization Project. Manila.

Central Bank of Sri Lanka. 2012. Economic and Social Statistics of Sri Lanka 2012. Colombo.

Colleges of Education Branch. 2001. Manual for the National Colleges of Education. Colombo: Ministry of Education.

B. David. 2004. A Study on Implementation of Continuing Teacher Education Programme. Colombo: National Education Commission.

Department of Teacher Education. (n.d.) A Self Evaluation System for Management of National Colleges of Education. Colombo: Ministry of Education and Higher Education.

W. De Silva. 2004. The Implementation of the Teacher Education Program at the National Institute of Education. Colombo: National Education Commission.

Government of Sri Lanka. 1992. The First Report of the National Education Commission. Colombo.

C. Gunawardene. 2005. Issues in Teacher Education. Colombo.

R. Gunawardene. 2004. The Teacher Education Programmes in Universities. Colombo: National Education Commission.

- - - 2011. A Study on the Effectiveness of Short-Term In-service Teacher Training in the Teaching-Learning Process. Colombo: National Education Commission.

N. Herath. 1998. Strategies for Effective Management of NCOEs. Colombo: Ministry of Education.

International Bank for Reconstruction and Development. 2011. Transforming School Education in Sri Lanka. Colombo: The World Bank.

A. Jayasena. 2004. The Teacher Education Programme in National Colleges of Education. Colombo: National Education Commission.

W. Kotalawala. 2004. Teacher Education Programmes in Universities. Colombo: National Education Commission.

Management and Quality Assurance Branch (MQAB). 2010. Quality Development of the Process of School System of Education 111: Guidelines of National Educational Standards and ISA Competencies. Colombo: Ministry of Education.

- - . 2012. Annual Report on Quality Assurance in School Education. Colombo: Ministry of Education.

Ministry of Education (MOE). 2000. Quality Development Process of School EducationInstructions on Internal Evaluation. Colombo.

- - . 2005. Implementation Completion Report, Sri Lanka Teacher Education and Teacher Deployment Project, 2005. Colombo.

- - . 2007. Education Sector Development Framework and Program. Colombo.

- - 2011a. Ministry of Education: Progress and Recent Trends. Colombo.

-_- 2011b. New Vision for Education: 2010 Progress and Proposed Programmes 2011.

Colombo. 
-_- 2012a. Code and System of Ethics on the Moral Conduct of Teachers. Colombo.

- - . 2012b. New Vision for Education and Milestones of Progress: Progress in 2012 and Proposed Programmes in 2013. Colombo.

- - - 2012c. The National Strategic Plan for the General Education Sector: Educational Sector Development Framework and Programmes (2012-2016). Colombo.

- - . 2013. "Education First" Education Sector Development Framework and Program (2013-2017). Colombo. 


\section{Innovative Strategies for Accelerated Human Resource Development in South Asia Teacher Professional Development \\ Special Focus on Bangladesh, Nepal, and Sri Lanka}

Significant investments have been made to modernize and improve the provision of education services. Strengthening teacher development has been a key component of these investments. However, programs on teacher development have provided mixed results. This report adopts a 360-degree perspective to review the current status of teacher development, demand and supply, and performance management in five countries from the South Asia region including Bangladesh, Nepal, and Sri Lanka, with limited reference to Bhutan and Maldives. It probes beyond teacher in-service training and teacher job conditions, and investigates systemic and structural issues. Continued investment may not be the best option to improve the quality and supply of teachers, and so the challenge is how to leverage resources to meet the demand.

\section{About the Asian Development Bank}

ADB's vision is an Asia and Pacific region free of poverty. Its mission is to help its developing member countries reduce poverty and improve the quality of life of their people. Despite the region's many successes, it remains home to a large share of the world's poor. ADB is committed to reducing poverty through inclusive economic growth, environmentally sustainable growth, and regional integration.

Based in Manila, ADB is owned by 67 members, including 48 from the region. Its main instruments for helping its developing member countries are policy dialogue, loans, equity investments, guarantees, grants, and technical assistance. 